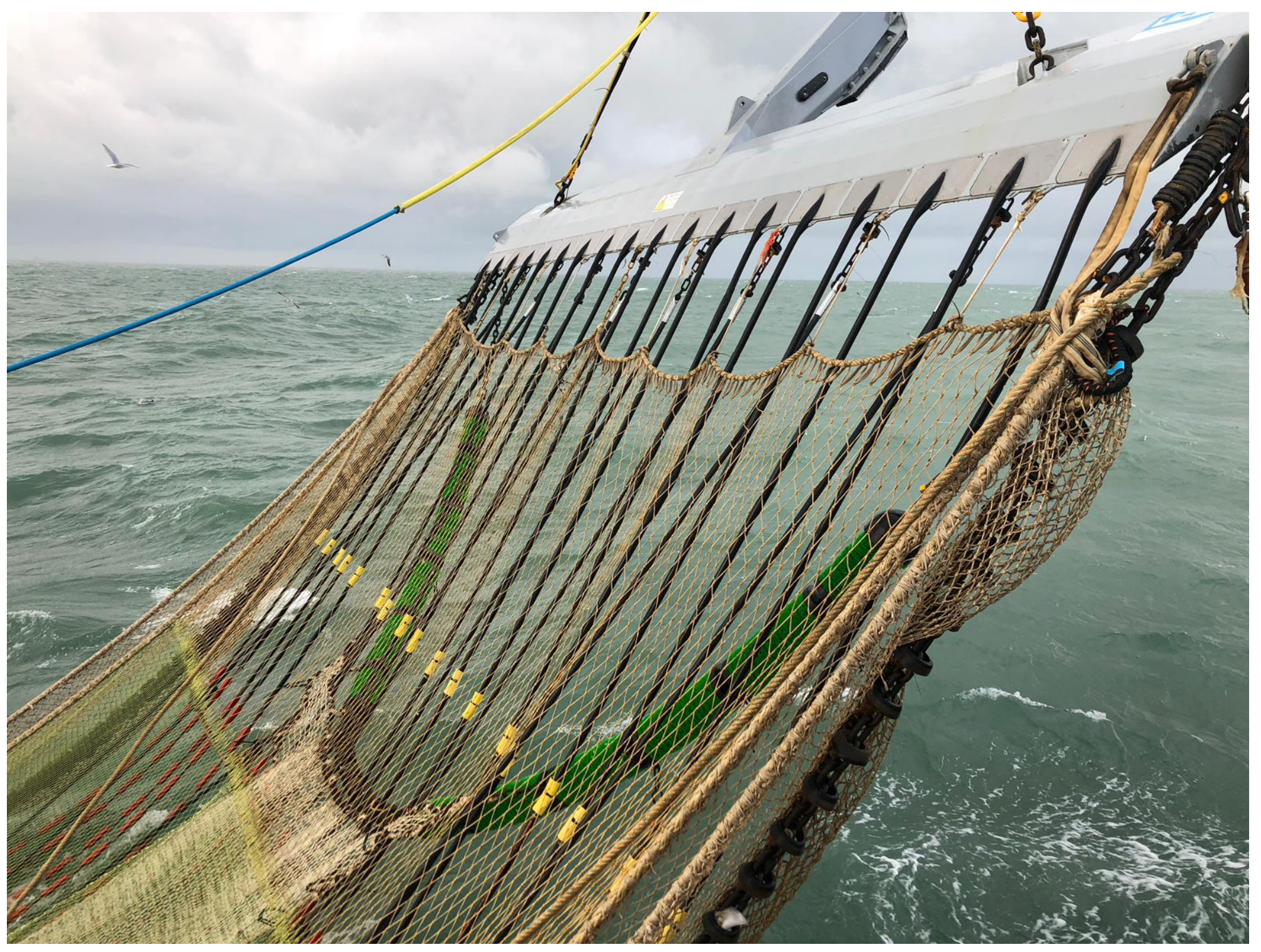

\title{
Netinnovatie Kottervisserij II
}

Auteurs: P. Molenaar ${ }^{1}$, M. Soetaert ${ }^{2}$, S. Glorius ${ }^{1}$ en M. Van Opstal ${ }^{2}$

${ }^{1}$ Wageningen Marine Research

2 ILVO 


\section{Netinnovatie Kottervisserij II}

Auteurs: $\quad$ P. Molenaar ${ }^{1}$, M. Soetaert ${ }^{2}$, S. Glorius ${ }^{1}$ en M. Van Opstal ${ }^{2}$

${ }^{1}$ Wageningen Marine Research

${ }^{2}$ ILVO

Wageningen Marine Research

IJmuiden, mei 2019

VERTROUWELIJK Nee

Wageningen Marine Research rapport C051/19 
Keywords: Netinnovatie, discards, bijvangst, innovatie, tongvisserij, flyshoot, Noorse kreeft visserij, selectieve visserij

Opdrachtgever: De Nederlandse Vissersbond

T.a.v.: Derk Jan Berends

Het Spijk 20

8321WT Urk

Dit rapport is gratis te downloaden van https://doi.org/10.18174/477744

Wageningen Marine Research is ISO 9001:2015 gecertificeerd.

Foto omslag: Dirk Kraak

Het project Netinnovatie Kottervisserij deel 2 is een initiatief van de Nederlandse Vissersbond namens de kottersector met steun uit het Europees Fonds voor Maritieme Zaken en Visserij (EFMZV) en is uitgevoerd in samenwerking met vissers, nettenmakers en onderzoekers van Wageningen Marine Research en het ILVO.

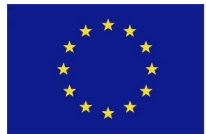

European Union,

European Maritime

and Fisheries Fund 


\section{Inhoudsopgave:}

$\begin{array}{lr}\text { Samenvatting } & 4\end{array}$

$1 \quad$ Inleiding $\quad 6$

$\begin{array}{lll}1.1 & \text { Kennisvraag } & 7\end{array}$

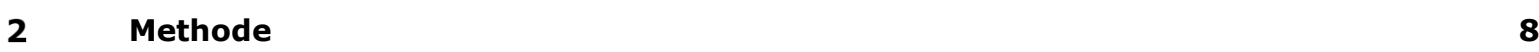

2.1 Bemonstering vangstsamenstelling $\quad 9$

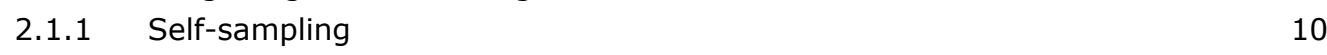

2.1.2. Waarnemersreis $\quad 10$

$\begin{array}{llr}3 & \text { Tongvisserij } & 11\end{array}$

3.1 Inleiding 11

3.2 Onderwater beelden visgedrag in pulstuigen $\quad 11$

$\begin{array}{ll}3.3 & \text { Deelnemende schepen } \\ 3.4 & 11\end{array}$

3.4 Elektrisch benthos ontsnappingspaneel (eBRP) 12

3.4.1 Inleiding en beschrijving 12

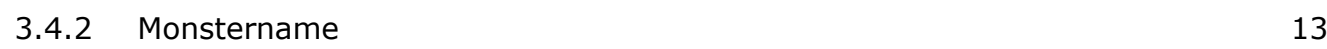

$\begin{array}{lll}3.4 .3 & \text { Resultaten } & 14\end{array}$

$\begin{array}{lll}3.4 .4 & \text { Conclusie } & 16\end{array}$

$\begin{array}{lll}3.5 & \text { Touwtjes paneel } & 17\end{array}$

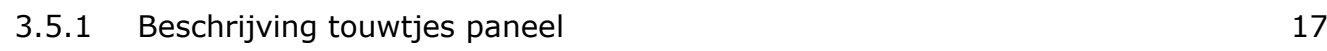

$\begin{array}{lll}3.5 .2 & \text { Resultaten self-sampling } & 18\end{array}$

$\begin{array}{lll}3.5 .3 & \text { Verlengt touwtjespaneel } & 20\end{array}$

3.5.4 Resultaten verlengt touwtjespaneel $\quad 21$

$\begin{array}{ll}3.5 .5 & \text { Conclusie touwtjespaneel } \\ \end{array}$

$\begin{array}{lll}3.6 & \text { Pulse selector } & 23\end{array}$

$\begin{array}{lll}3.6 .1 & \text { Beschrijving Pulse selector } & 23\end{array}$

$\begin{array}{lll}3.6 .2 & \text { Praktijkproef Pulse selector } & 24\end{array}$

3.6.3 Pulse Selector met borstelpees $\quad 25$

3.6.4 Proefopzet pulse selector met borstelpees 26

$\begin{array}{lll}3.6 .5 & \text { Praktijktest Puls selector met borstelpees } & 27\end{array}$

$\begin{array}{lll}3.7 & \text { Schanspaneel } & 27\end{array}$

$\begin{array}{lll}\text { 3.7.1 Inleiding en beschrijving } & 27\end{array}$

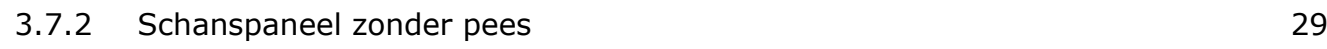

$\begin{array}{lll}\text { 3.7.3 Schanspaneel met extra onderpees } & 29\end{array}$

3.7.4 Resultaten self-sampling schanspaneel 30

3.7.5 Resultaten self-sampling schanspaneel met extra onderpees 31

$\begin{array}{lll}3.7 .6 & \text { Conclusie } & 31\end{array}$

$\begin{array}{lll}3.8 & \text { Kiwikuil } & 32\end{array}$

3.8.1 Inleiding en beschrijving $\quad 32$

$\begin{array}{lll}3.8 .2 & \text { Proefopzet } & 32\end{array}$

$\begin{array}{lll}3.8 .3 & \text { Monitoren visconditie } & 33\end{array}$

3.8.4 Resultaten self-sampling kiwikuil 33

$\begin{array}{lll}3.8 .5 & \text { Verlengde kiwikuil } & 35\end{array}$

3.8.6 Resultaten self-sampling verlengde kiwikuil 36

$\begin{array}{lll}3.8 .7 & \text { Conclusie } & 37\end{array}$

$\begin{array}{ll}3.9 & \text { Lucht puls } \\ 3.9 .1 & 37\end{array}$

$\begin{array}{lll}3.9 .1 & \text { Doel experiment } & 38\end{array}$

$\begin{array}{lll}3.9 .2 & \text { Ethische gronden } & 38\end{array}$ 
$\begin{array}{lll}3.9 .3 & \text { Locatie } & 38\end{array}$

$\begin{array}{lll}3.9 .4 & \text { Proefdieren } & 38\end{array}$

$\begin{array}{lll}3.9 .5 & \text { Materialen } & 38\end{array}$

$\begin{array}{lll}3.9 .6 & \text { Proefopzet } & 40\end{array}$

$\begin{array}{lll}3.9 .7 & \text { Resultaten } & 40\end{array}$

3.9.8 Conclusie $\quad 44$

$4 \quad$ Noorse Kreeften visserij $\quad 45$

4.2 Inleiding $\quad 45$

4.3 Deelnemende schepen $\quad 45$

$\begin{array}{lll}4.4 & \text { SepNep } & 45\end{array}$

4.4.1 Vangstvergelijking markwaardige Noorse kreeft $\quad 47$

$\begin{array}{lll}4.4 .2 & \text { Optimalisatie SepNep } & 48\end{array}$

4.4.3 Bevindingen SepNep testen breder in de vloot 50

$\begin{array}{lll}4.5 & \text { Swedish Grid } & 51\end{array}$

4.5.1 Swedish grid praktijktesten $\quad 53$

4.5.2 Praktijktesten verbeterde Swedish grid $\quad 54$

4.5.3 Resultaten waarnemersreis met verbeterd Swedish grid 55

$\begin{array}{ll}\text { 4.5.4 Conclusie en discussie } & 59\end{array}$

$5 \quad$ Flyshoot $\quad 60$

$\begin{array}{lll}5.2 & \text { Literatuuronderzoek } & 60\end{array}$

5.2.1 Conclusies $\quad 60$

5.2.2 Hypothetische netaanpassingen op basis van literatuur 61

$\begin{array}{lll}5.3 & \text { Mogelijke netaanpassingen } & 61\end{array}$

$\begin{array}{lll}\text { 5.3.1 Overzicht } & 61\end{array}$

5.3.2 Beschrijving getest ontsnappingspaneel $\quad 62$

5.4 Onderwateropnames $\quad 63$

5.4.1 Doelstelling 63

$\begin{array}{lll}5.4 .2 & \text { Methode } & 63\end{array}$

$\begin{array}{lll}5.4 .3 & \text { Resultaten } & 63\end{array}$

$\begin{array}{lll}5.4 .4 & \text { Conclusie } & 64\end{array}$

5.5 Vangstanalyse ontsnappingspaneel $\quad 65$

$\begin{array}{lll}5.5 .1 \quad \text { Inleiding } & 65\end{array}$

$\begin{array}{lll}5.5 .2 & \text { Resultaten self-sampling } & 65\end{array}$

5.5.3 Methode vangstanalyse $\quad 66$

$\begin{array}{lll}\text { 5.5.4 } & \text { Resultaten waarnemersreis } & 66\end{array}$

$\begin{array}{lll}5.5 .5 & \text { Discussie } & 70\end{array}$

$\begin{array}{lll}\text { 5.5.6 Conclusie } & 70\end{array}$

$\begin{array}{lll}5.6 & \text { Conclusies en aanbevelingen } & 70\end{array}$

$\begin{array}{lll}5.6 .1 & \text { Eindconclusies } & 70\end{array}$

$\begin{array}{lll}\text { 5.6.2 Suggesties verder onderzoek } & 71\end{array}$

6 Schol visserij $\quad 72$

$\begin{array}{lll}6.2 & \text { Inleiding } & 72\end{array}$

6.3 Bijvangst beperkende net-aanpassingen $\quad 72$

$7 \quad$ Conclusies en aanbevelingen $\quad 73$

$\begin{array}{lll}7.2 & \text { Tongvisserij } & 73\end{array}$

7.2.1 Elektrisch benthos ontsnappingspaneel (eBRP) 73

$\begin{array}{lll}7.2 .2 & \text { Touwtjespaneel } & 73\end{array}$

$\begin{array}{lll}7.2 .3 & \text { Pulse Selector } & 73\end{array}$

$\begin{array}{lll}7.2 .4 & \text { Schanspaneel } & 73\end{array}$ 
$\begin{array}{lll}7.2 .5 & \text { Kiwikuil } & 73\end{array}$

\begin{tabular}{ll}
7.2 .6 & Luchtpuls \\
\hline
\end{tabular}

$\begin{array}{lll}7.3 & \text { Noorse kreeften visserij } & 74\end{array}$

$\begin{array}{lll}\text { 7.3.1 SepNep } & 74\end{array}$

$\begin{array}{lll}7.3 .2 & \text { Swedish grid } & 74\end{array}$

$\begin{array}{lll}7.4 & \text { Flyshoot } & 74\end{array}$

$\begin{array}{lll}7.5 & \text { Scholvisserij } & 75\end{array}$

$\begin{array}{lr}\text { Kwaliteitsborging } & 76\end{array}$

$\begin{array}{lr}\text { Literatuur } & 77\end{array}$

$\begin{array}{lr}\text { Verantwoording } & 79\end{array}$

$\begin{array}{lll}\text { Bijlage 1: } \quad \text { Verslag bemonsteringsreis eBRP } & 81\end{array}$

$\begin{array}{llr}\text { Bijlage 2: } \quad \text { Touwtjespaneel } & 84\end{array}$

$\begin{array}{llr}\text { Bijlage 3: } & 90\end{array}$

$\begin{array}{llr}\text { Bijlage 4: } \quad \text { Schans paneel } & 93\end{array}$

$\begin{array}{lll}\text { Bijlage 5: } & \text { Verslag en ontwerp kiwikuil } & 98\end{array}$

Bijlage 6: $\quad$ Ervaringen SepNep breder in de vloot $r 12$

$\begin{array}{llr}\text { Bijlage 7: } & \text { Reisverslag Swedish grid } & 114\end{array}$

Bijlage 8: $\quad$ Reisverslag studiereis Noorse kreeft en netinnovatie 131

Bijlage 9: $\quad$ Flyshoot: Overzicht literatur wijting $\quad 141$

$\begin{array}{ll}\text { Bijlage 10: } & 146\end{array}$

i. $\quad$ Waarnemingen SCH135 april 2018

ii. Waarnemingen SCH135 januari $2019 \quad 151$

$\begin{array}{lr}\text { Bijlage 11: } & 155\end{array}$

iii. $\quad$ Reis 1 (maart 2017): net zonder aanpassingen 155

iv. $\quad$ Reis 2 (april 2018): net met ontsnappingspaneel (rug) en extra stimuli 156

v. Reis 3 (januari 2019): vangstanalyse 157 


\section{Samenvatting}

Om de gefaseerde implementatie van de aanlandplicht uitvoerbaar te maken is een selectiviteitsverbetering nodig voor de Nederlandse Demersale visserijen. Met op de huidige ongewenste bijvangsten is het uitvoeren van de aanlandplicht problematisch. Binnen het project Netinnovatie Kottervisserij II (NIKOII) zijn voor de voor de tong- en Noorse kreeftenvissenrij met gesleepte vistuigen, de flyshoot (allen $80 \mathrm{~mm}$ maaswijdte) en de $100+\mathrm{mm}$ scholvisserij netinnovaties ontworpen en getest om ongewenste bijvangsten te verminderen. Hierbij zijn verschillende technieken gebruikt; scheidingspanelen en sorteerroosters in de visserij op Noorse kreeft en ontsnappingspanelen in de flyshoot. In de tongvisserij is er geëxperimenteerd met ontsnappings- en scheidingspanelen, borstelpezen, een nieuw ontwerp van de kuil en een alternatieve methode om schol en tong in het net te krijgen. Netontwerpen zijn zowel op schaal als in de praktijk getest, waarbij data over de werking van de innovatie is verzameld op basis van self-sampling door de bemanning van de kotters en uitgebreide monitoring door waarnemers. Een samenvattend overzicht van de proeven per visserij en beknopte resultaten is hieronder in Tabel 1. 
Tabel 1. Overzicht geteste netinnovaties per visserij. Per test is aangegeven wat het doel van de netinnovatie was, de soorten waarop de innovatie gericht was, de gebruikte techniek en een korte samenvatting van het resultaat.

\begin{tabular}{|c|c|c|c|c|c|}
\hline Visserij & Netinnovatie & Doel & Techniek & Aanpassing gericht op & Resultaat \\
\hline Tong puls & $\begin{array}{l}\text { Elektrisch Benthos } \\
\text { Release panel }\end{array}$ & $\begin{array}{l}\text { Vermindering } \\
\text { bijvangst }\end{array}$ & Ontsnappingspaneel & $\begin{array}{l}\text { Benthos, debris, maatse tong, } \\
\text { ondermaatse schol }\end{array}$ & $\begin{array}{l}\text { Effectief voor verminderen bijvangst benthos } \\
\text { en stenen. Geen effect op maatse } \\
\text { tongvangsten. }\end{array}$ \\
\hline Tong puls & Touwtjes paneel & $\begin{array}{l}\text { Vermindering } \\
\text { bijvangst }\end{array}$ & Scheidingspaneel & Maatse tong, maatse schol & $\begin{array}{l}\text { Scheiding maatse tong } 50 \text { tot } 60 \% \text { maar } \\
\text { onvoldoende voor commerciële toepassing. } \\
\text { Verdere doorontwikkeling essentieel. }\end{array}$ \\
\hline Tong puls & Pulse Selector & $\begin{array}{l}\text { Vermindering } \\
\text { bijvangst }\end{array}$ & Scheidings(borstel)pees & Ondermaatse schol, schar & $\begin{array}{l}\text { Geen verlies marktwaardige vis. Ontwerp } \\
\text { extra kuil dient verbeterd te worden voor } \\
\text { aanvullende testen. }\end{array}$ \\
\hline Tong puls & Schanspaneel & $\begin{array}{l}\text { Vermindering } \\
\text { bijvangst }\end{array}$ & Scheidingspaneel & Wijting, kabeljauw & $\begin{array}{l}\text { Paneel met onderpees vangt } 2.5 \text { keer zo veel } \\
\text { ondermaatse wijting met } 15 \% \text { verlies } \\
\text { marktwaardige tong. }\end{array}$ \\
\hline Tong puls & Kiwikuil & $\begin{array}{l}\text { Vangst efficiëntie } \\
\text { behouden, } \\
\text { verbeteren } \\
\text { overleving, } \\
\text { verminderen } \\
\text { mechanische } \\
\text { belasting van de vis } \\
\text { in de kuil }\end{array}$ & Nieuw ontwerp kuil & Ondermaatse schol, tong & $\begin{array}{l}\text { Verlies marktwaardige tong en schol door } \\
\text { kiwikuil maar minder beschadigingen } \\
\text { aangetroffen op de ondermaatse schol. Verder } \\
\text { verbeteren doorstroming water in kuil } \\
\text { essentieel. }\end{array}$ \\
\hline Tong & Lucht puls & $\begin{array}{l}\text { Alternatief voor } \\
\text { pulsvisserij of } \\
\text { wekkerkettingen }\end{array}$ & Nieuwe vistechniek & Maatse tong, schol & $\begin{array}{l}\text { Zeer beperkte reactie vissen, in deze } \\
\text { opstelling geen alternatief voor } \\
\text { wekkerkettingen of puls }\end{array}$ \\
\hline $\begin{array}{l}\text { Noorse } \\
\text { Kreeft }\end{array}$ & SepNep & $\begin{array}{l}\text { Vermindering } \\
\text { bijvangst }\end{array}$ & $\begin{array}{l}\text { Scheidingspaneel en } \\
\text { sorteerrooster }\end{array}$ & Ondermaatse schol, schar & $\begin{array}{l}\text { SepNep vangt } 97 \% \text { Noorse kreeft ten opzichte } \\
\text { van conventionele netten. Sorteergrid kleine } \\
\text { Noorse kreeft dient verder ontwikkeld te } \\
\text { worden. }\end{array}$ \\
\hline $\begin{array}{l}\text { Noorse } \\
\text { Kreeft }\end{array}$ & Swedish grid & $\begin{array}{l}\text { Vermindering } \\
\text { bijvangst }\end{array}$ & Sorteerrooster & Ondermaatse schol & $\begin{array}{l}\text { Door het grid wordt } 61 \% \text { ondermaatse schol } \\
\text { en } 24 \% \text { ondermaatse wijting gescheiden en } \\
6 \% \text { maatse Noorse kreeft in bovenkuil } \\
\text { aangetroffen. Stabiliteit grid dient verbeterd te } \\
\text { worden. }\end{array}$ \\
\hline Flyshoot & Ontsnappingspaneel & $\begin{array}{l}\text { Vermindering } \\
\text { bijvangst }\end{array}$ & Ontsnappingspaneel & Ondermaatse wijting & $\begin{array}{l}\text { Reductie bijvangst ondermaatse wijting van } \\
48 \% \text {, van maatse wijting klasse } 4 \text { en } 3 \\
\text { ontsnapt en } 29 \% \text { en } 13 \% \text { door het paneel. } \\
\text { Ontsnapping van andere commerciële vis is } \\
\text { beperkt, het grootste verlies (tot } 20 \% \text { ) is dat } \\
\text { van kleine mul ( }<18 \mathrm{~cm} \text { ). Andere soorten } \\
\text { ontsnappen nauwelijks, inktvis ontsnapt niet. }\end{array}$ \\
\hline Scholvisserij & - & $\begin{array}{l}\text { Vermindering } \\
\text { bijvangst }\end{array}$ & - & Ondermaatse schol, rog & $\begin{array}{l}\text { Door toestaan gebruik grotere maaswijdten } \\
\text { verminderd animo onder vissers voor } \\
\text { selectieve netontwerpen }\end{array}$ \\
\hline
\end{tabular}




\section{Inleiding}

Het nieuwe Gemeenschappelijk Visserijbeleid (GVB) is op 1 januari 2014 ingegaan en geldt voor 10 jaar. In het GVB zijn een aantal verstrekkende maatregelen opgenomen voor de visserij, de aanlandplicht (European Union, 2013) is hier één van, en deze is tussen 2016 en 2019 gefaseerd ingevoerd voor de Nederlandse demersale visserij. Het doel van de aanlandplicht is het verder verduurzamen van de visserij door onder andere de wijziging van het huidig geldende aanlandquotum naar een vangstquotum. Voor bepaalde soorten geldt dat er geen discarding meer mag plaatsvinden en dat zowel maatse als ondermaatse, marktwaardige als niet marktwaardige vis welke onderhevig zijn aan vangstquota moet worden aangeland.

De veranderingen van de afgelopen jaren in de Nederlandse demersale visserij en de resultaten uit de voorgaande projecten bieden aanleiding om een vervolgproject te starten naar netinnovatie in deze sector. De Nederlandse vloot is afgenomen en alternatieve vistechnieken zoals de pulskor, twinrig, quad-rig en flyshoot hebben hun intrede gedaan. Deze voor de Nederlandse demersale visserij nieuwe(re) technieken kunnen profijt hebben van verbetering op het gebied van selectiviteit. Met selectiviteit van een vistuig wordt bedoeld de mate waarin met het vistuig ongewenste bijvangsten gevangen worden ten opzichte van de hoeveelheden marktwaardige doelsoorten in de vangst. Hoe selectiever een vistuig is, hoe minder ongewenste bijvangsten gevangen worden. Verdere verbetering van de selectiviteit is belangrijk omdat dit bijdraagt aan het verminderen van de visserijsterfte van bijgevangen ondermaatse vis, daarnaast wordt de aanlandplicht beter uitvoerbaar omdat een kotter een kleinere hoeveelheid ondermaatse vis aan boord hoeft te houden.

Van april 2014 tot en met december 2015 heeft er een project "Netinnovatie Kottervisserij" plaatsgevonden met als doel de verbetering van de selectiviteit in de demersale vistuigen gericht op de visserij op schol en tong (van Marlen et al, 2016). Dit project was een vervolg op het project "Vermindering discards door Technische Netaanpassingen (VDTN)" (van Marlen et al, 2013). Daarnaast is in dezelfde periode binnen het project 'Sectorale en keten integrale Aanpak Noorse Kreeft' gewerkt aan netinnovaties in de Noorse kreeften visserij (Molenaar et al, 2016). Dat laatste project is een vervolg geweest op 'Less Fuel and Discards in de Noorse kreeft visserij' (Steenbergen et al, 2012). Deze projecten zijn allemaal wetenschappelijk begeleid door Wageningen Marine Research (destijds IMARES). In België werkte het ILVO binnen project TECHVIS1 aan het verhogen van de selectiviteit in de platvisvisserij (TECHVIS IWT LBO - LA 120755). Specifiek werden door ILVO o.a. experimenten uitgevoerd met 90 graden gedraaide mazen in de kuil (T90) en elektrische benthos ontsnappingspanelen (eBRP) (Bayse et al, 2015; Soetaert et al, 2016).

Rekening houdende met de gefaseerde implementatie van de aanlandplicht in de demersale visserij, streeft de Nederlandse sector naar verdere selectiviteitsverbetering zodat de aanlandplicht beter uitvoerbaar wordt. Met het oog op de huidige ongewenste bijvangsten in de demersale visserijen (Verkempynck et al., 2018 ) is het uitvoeren van de aanlandplicht problematisch. De resultaten uit de voorgaande projecten tonen aan dat er stapsgewijs selectiviteitsverbeteringen mogelijk zijn. Echter, bij elke aanpassing is er ook een risico dat er naast minder bijvangsten ook minder marktwaardige vis gevangen wordt. Daarnaast zijn netaanpassingen en bijbehorende effecten per visserijmethode dermate verschillend dat het nodig wordt geacht om een vierdeling in het nieuwe project toe te passen voor de volgende visserijmethoden:

- Tongvisserij met gesleepte tuigen, maaswijdte $80 \mathrm{~mm}$

- $\quad$ Noorse Kreeft visserij met gesleepte tuigen, maaswijdte $80 \mathrm{~mm}$

- Flyshoot (gemengde vangst), maaswijdte $80 \mathrm{~mm}$

- Scholvisserij met gesleepte tuigen, maaswijdte $100+\mathrm{mm}$

\footnotetext{
${ }^{1}$ TECHVIS IWT LBO - LA 120755 - TECHnische innovaties voor een transitie naar een duurzame zeeVISserijsector
} 


\subsection{Kennisvraag}

Het project "Netinnovatie kottervisserij deel II (NIKO2)" had de volgende doelstellingen:

- $\quad$ Het verbeteren van de selectiviteit in de tongvisserij (puls $80 \mathrm{~mm}$ ), Noorse kreeft visserij (twin/quad-rig $80 \mathrm{~mm}$ ), scholvisserij (boomkor en twinrig $100+\mathrm{mm}$ ) en flyshoot (gemengde visserij $80 \mathrm{~mm}$ ).

- Het kwantificeren van het effect van netinnovaties op de selectiviteit van het vistuig ten opzichte van het traditionele tuig in de betreffende visserijtechniek.

- Het verbeteren van de samenwerking tussen visserijondernemers, visserij coöperaties en nettenmakers op het gebied van netinnovatie, zowel nationaal als internationaal.

Wageningen Marine Research en ILVO verzorgden in dit project de wetenschappelijke begeleiding. Tabel 1 geeft de binnen NIKOII geteste netinnovaties weer. Deze innovaties worden verder uitgewerkt in de hoofdstukken van dit rapport. 


\section{Methode}

In het project netinnovatie kottervisserij is het WMR-innovatiemodel (van Marlen et al, 2016; Molenaar et al, 2016) gebruikt voor het ontwikkelen en begeleiden van de geteste netontwerpen. Middels dit stappenplan heeft WMR de veldtesten begeleid en gegevens verzameld volgens vaste protocollen. Met behulp van deze gegevens is beoordeeld of de innovaties de beoogde doelen behaalden bij toepassing in het veld. Dit model (Figuur 1 ) is onderverdeelt in de volgende fases:
1. Ontwikkelfase
2. Testfase
3. Onderzoeksfase
4. Uitrolfase

\section{Ontwikkelfase}

Tijdens deze eerste fase zijn per visserijtechniek nieuwe netontwerpen aangedragen en besproken door de projectgroep. Als input voor deze nieuwe ontwerpen is er gekeken naar ontwikkelingen in het buitenland en onderwateropnamen van het gedrag van vis tijdens het vangstproces. Aangewezen leden van de projectgroep doen voorstellen voor potentiele innovaties, gezamenlijk wordt besloten welke potentiele innovaties getest dienen te worden. Hierbij worden ook de ervaringen van de reeds geteste vergelijkbare innovaties uit de voorgaande projecten meegenomen. In deze fase zijn de nieuwe ontwerpen eerst getest op zee door de vissers en/of als schaalmodel in een flumetank. Hierbij wordt een eerste globale indruk verkregen van de effectiviteit of het zinvol is om de innovatie verder te ontwikkelen.

\section{Testfase}

In de testfase wordt data verzameld tijdens praktijktesten met de ontwikkelde netten. Tijdens deze fase kunnen de netten (aan boord) worden verbeterd tot een goed concept waarmee langere tijd gevist kan worden. In deze fase nemen de vissers monsters van hun vangst middels een protocol voor self-sampling dat is ontwikkeld door WMR. Aangezien omstandigheden per schip verschillen worden de protocollen per schip en innovatie op maat gemaakt. Doel van de self-sampling is om een eerste indruk te krijgen van de effectiviteit van het aangepaste net. De uitkomsten van deze exercitie waren bepalend voor de overgang naar de volgende fase. Aan het einde van deze fase zijn de resultaten teruggekoppeld naar de projectgroep en hebben de betrokkenen bepaald of de netaanpassing voldoende perspectief heeft laten zien om getest te worden in de onderzoeksfase.

\section{Onderzoeksfase}

Tijdens deze fase zijn wetenschappelijke vangstvergelijkingen (door een onderzoeker van WMR of ILVO) uitgevoerd voor de meest kansrijke netontwerpen uitgevoerd om de effectiviteit vast te stellen. Hiervoor zijn detailmetingen gedaan van de marktwaardige vangst en de ongewenste bijvangst in zowel het nieuwe netontwerp als het conventionele netontwerp.

\section{Uitrolfase}

In deze fase zijn de in de onderzoekfase geteste en goed bevonden innovaties toegepast op meerdere schepen. Deze schepen hielden gegevens bij volgens een vast, door WMR opgesteld protocol. 


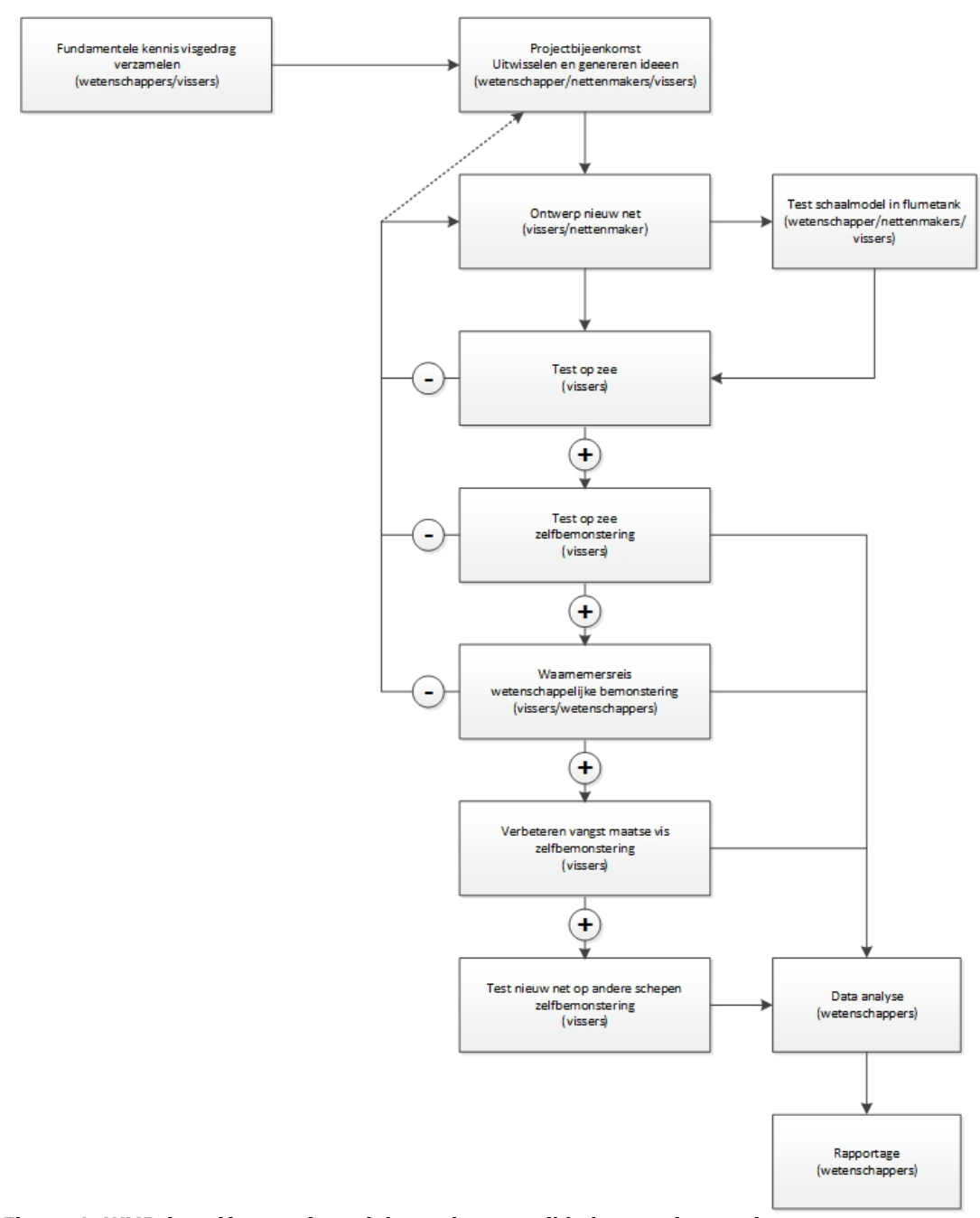

Figuur 1. WMR (net-)innovatiemodel voor het ontwikkelen van innovatieve netten.

\subsection{Bemonstering vangstsamenstelling}

Om de effectiviteit van de innovatieve visnetten te onderzoeken is er naar de vangstsamenstelling van het innovatieve net gekeken en vergeleken met de vangst uit een conventioneel net. Voor beide netten werd de vangst uitgezocht en werd de marktwaardige vis apart gehouden zoals weergegeven in Figuur 2. Deze bemonstering kan door de bemanning van de kotter uitgevoerd worden (self-sampling) of door een waarnemer. Voor beide vormen van bemonstering heeft WMR of ILVO een protocol opgesteld om gestructureerd data te verzamelen. Om een indruk te krijgen van de werking van de innovatie maar de bemanning van de kotter niet te veel te belasten werd er met een self-samplingprotocol minder gedetailleerde data verzameld dan wat er met een waarnemersreis. Hieronder wordt per type protocol een beschrijving gegeven van beide protocollen. 


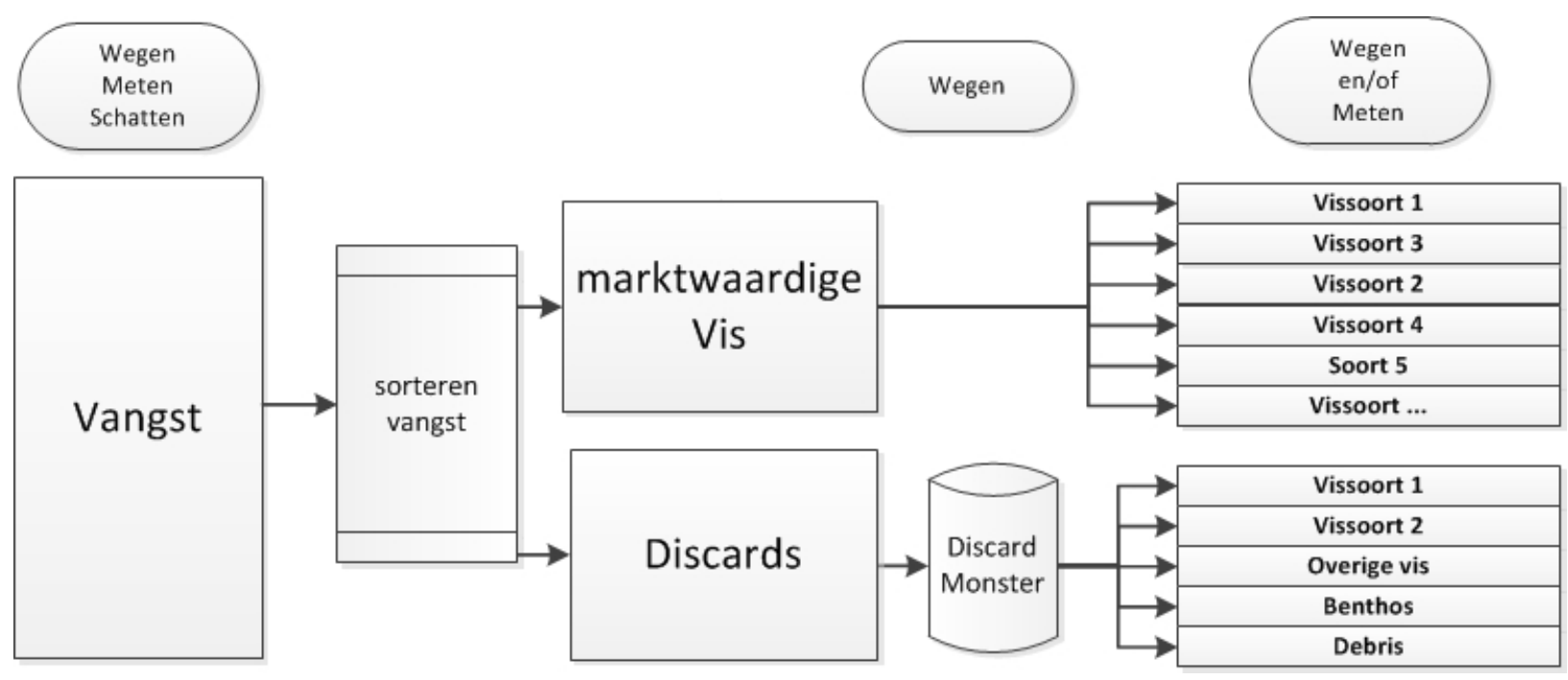

Figuur 2. Bemonsterings-schema vangstsamenstelling.

\subsubsection{Self-sampling}

De bemanningen van de kotters waarop netinnovaties waren geïmplementeerd, werden verzocht meerdere trekken per netaanpassing te bemonsteren, bij voorkeur zowel dagtrekken als nachttrekken. Het bemonsteringsprotocol is voorbereid en opgestuurd naar de kotters met daarbij een beschrijving die uitleg geeft over de wijze waarop de bemonstering gedaan moest worden. Belangrijk is om de locatie, tijd en de aanpassingen in het net per trek te noteren. $\mathrm{Na}$ het binnen halen van de netten werd het gewicht per kuil gewogen, gemeten of geschat. Per kuil werd alle maatse vangst gesorteerd en per sortering gewogen. Tijdens het uit de vangst sorteren van de maatse vis werd een discard monster genomen door aan het einde van de sorteerband (alle maatse vis is daar al uit de vangst gepakt) drie keer een emmer van 12 liter te vullen aan het begin, midden en einde van het sorteringsproces. Dit discard monster wordt dan in zijn totaliteit gewogen en per soort uitgezocht en gewogen.

In een aantal gevallen was alleen de totale vangst van en de vangst van marktwaardige vis per soort belangrijk. Voor deze reizen is een aangepast protocol opgesteld waarbij alleen marktwaardige vis geregistreerd werd zonder discard monster

\subsubsection{Waarnemersreis}

Als de self-sampling en de resultaten daarvan een positief beeld gaven van de netinnovatie werd een reis ingepland waarbij een waarnemer de werking van de innovatie net middels een volledige vangstvergelijking ging onderzoeken. Bij deze reizen is een vangstvergelijking gedaan op basis van het registreren van alle maatse vis en het nemen van een discardmonster (Figuur 2). Na het sorteren en wegen van de discard fracties werden ook alle vissen uit het discardsample op lengte gemeten. 


\title{
3 Tongvisserij
}

\author{
3.1 Inleiding
}

De gemengde demersale visserij op tong (solea solea) wordt jaarrond beoefend in de Noordzee voornamelijk met gesleepte boom- of pulskor tuigen (TBB), waarbij er wekkerkettingen of elektriciteit (puls) gebruikt worden om de doelsoorten uit de zeebodem op te schrikken en te vangen. De minimale maaswijdte in de kuil in deze visserij bedraagt $80 \mathrm{~mm}$, deze maaswijdte is nodig om het grootste deel van de marktwaardige tong in het net te houden (Molenaar \& Chen, 2018). Echter, deze maaswijdte is niet selectief voor de (bij)vangst van de overige rond- en platvissoorten. De samenstelling van de marktwaardige vangst bestaat hoofdzakelijk uit schol en tong met beperkte bijvangsten van tarbot en griet. Ongewenste bijvangst bestaat hoofdzakelijk uit ondermaatse schol, schar en benthische organismen (Verkempynck et al., 2018). Onder een volledige invoering van de aanlandplicht (European Union, 2013) wordt in deze visserij vooral de bijvangst van ondermaatse schol $(<27 \mathrm{~cm})$ en wijting $(<26 \mathrm{~cm})$ als problematisch ervaren. De voorgestelde en ontwikkelde innovaties richten zich dan ook voornamelijk op het voorkomen van de vangst of laten ontsnappen deze soorten (Van Marlen et al. 2013; van Marlen et al. 2016; Soetaert et al. 2018). Bij het voorkomen van de vangst wordt gezocht naar een oplossing waarmee de ongewenste vis niet in het net komt. In het geval van ontsnappen is de vis in het net maar wordt een ontsnappingsmogelijkheid in het net gemaakt.

In de tongvisserij visserij is binnen NIKO2 op verschillende manieren geprobeerd om met netontwerpen en innovaties de ongewenste bijvangst van vis en benthos te beperken. Hierbij is zowel gebruik gemaakt van het scheiden van doelsoorten en bijvangst op basis van verschillen in gedrag en vorm als het immobiliseren van de doelsoorten. Hierbij zijn verschillende scheidings- en ontsnappingspanelen in het net toegepast en methoden om de soorten voor de grondpees te scheiden. Daarnaast is er nog een proef gedaan om te onderzoeken of platvis uit de bodem gejaagd kan worden met behulp van luchtdruk. Elk ontwerp is uitgewerkt in een paragraaf in dit hoofdstuk met daarin een beschrijving van de methoden en de resultaten van de self-sampling (Fase 2) en waarnemersreizen (Fase 3).

\subsection{Onderwater beelden visgedrag in pulstuigen}

In voorgaande projecten zijn veel netontwerpen uitgeprobeerd middels 'trial en error', gerichte ontwikkeling selectieve ontwerpen met fundamentele kennis van het gedrag van de verschillende platvissoorten in pulsen boomkornetten ontbrak. Gedurende de looptijd van Netinnovatie Kottervisserij zijn er beelden beschikbaar gekomen van visgedrag in het net van een pulskor (Molenaar et al, 2018). Op 23 maart 2018 is in het kader van Netinnovatie Kottervisserij 2 er een bijeenkomst georganiseerd om samen met een groep tongvissers deze beelden te bekijken en analyseren om op basis daarvan nieuwe netontwerpen te ontwikkelen. Na deze bijeenkomst zijn er een aantal nieuwe ideeën voorgesteld die in paragraaf 3.5 verder uitgewerkt zijn.

\subsection{Deelnemende schepen}

Verschillende schepen hebben bijgedragen door binnen dit project netinnovaties te testen die waren gericht op het beperken van bijvangst in de tongvisserij. In totaal hebben zes pulskotters bijgedragen aan het project, de specificaties van de deelnemende schepen zijn hieronder weergegeven in Tabel 2. 
Tabel 2. Specificaties van de deelnemende schepen voor de netinnovaties in de tongvisserij.

\begin{tabular}{|c|c|c|c|c|c|c|}
\hline \multirow[t]{3}{*}{ Kenmerk/schip } & TX36 & TX94 Avontuur & BRA 5 & BRA 7 & WR244 & GO23 \\
\hline & Jan van Toon & & Pieter & Jade & Margretha & Cornelis \\
\hline & & & & & Hendrika & Jannetje \\
\hline Lengte (m) & 42.4 & 40 & 24 & 24 & 24.5 & 42.4 \\
\hline Breedte $(\mathrm{m})$ & 8.5 & 8.5 & 6 & 7 & 6 & 8.5 \\
\hline Diepte (m) & 5.2 & 5.3 & 3.3 & 4.3 & 2.7 & 5.2 \\
\hline Inhoud (GT) & 494 & 424 & 90 & 156 & 113 & 496 \\
\hline Motorvermogen (pk) & 1999 & 1529 & 300 & 500 & 300 & 1999 \\
\hline
\end{tabular}

\subsection{Elektrisch benthos ontsnappingspaneel (eBRP)}

\subsubsection{Inleiding en beschrijving}

Een benthos ontsnappingspaneel (BRP) is een paneel bestaande uit vierkante grote mazen dat kort voor de kuil in de buik van het net wordt gestoken. Het doel is om zoveel mogelijk benthos, stenen en afval te lozen. Dit bleek in het verleden goed te werken, maar het paneel werd weinig of nooit commercieel gebruikt omdat er ook maatse tong door het paneel ontsnapte. Daarom werd in recente jaren een kramppuls toegevoegd aan het paneel door het ILVO ten einde tong in kramp te brengen en op die manier het ontsnappen te beletten. Dit elektrisch benthos ontsnappingspaneel (electrified benthos release panel of eBRP) werd de voorbije jaren ontwikkeld en getest door het ILVO met verschillende maasgroottes en afmetingen en meest belovende resultaten werden voorlopig behaald met een $200 \mathrm{~mm}$ paneel, waarbij elke maas ongeveer 100 bij $100 \mathrm{~mm}$ meet. De eerste met een $200 \mathrm{~mm}$ paneel van $1.2 \mathrm{bij} 1.2 \mathrm{~m}$ en een kramppuls toonden aan dat 50 tot $70 \%$ van het benthos en afval geloosd kon worden zonder tongverlies. Het eBRP getest aan boord van de TX36 mat eveneens 1.2 bij $1.2 \mathrm{~m}$ en had vierkante mazen van 100 bij $100 \mathrm{~mm}$ en zat $2 \mathrm{~m}$ voor de kuil, op deze positie dekt het eBRP niet de volledige breedte van de onderzijde van het net (bijlage 1). Het ontsnappingspaneel werd door HFK engineering voorzien van 3 elektrodes die op $50 \mathrm{~cm}$ van elkaar lagen (Figuur 3). Deze werden aangevuld door een pulsmodule die in de rug van het net werd gehangen en gevoed werd met een kabel vertrekkende uit de vleugel. De gebruikte puls op het eBRP was doorheen de hele proefperiode dezelfde en bedroegen 60 bipolaire pulsen per seconde (30 Hz) bij een puls breedte van $270 \mu$ s en een spanning van ongeveer $57 \mathrm{~V}$.

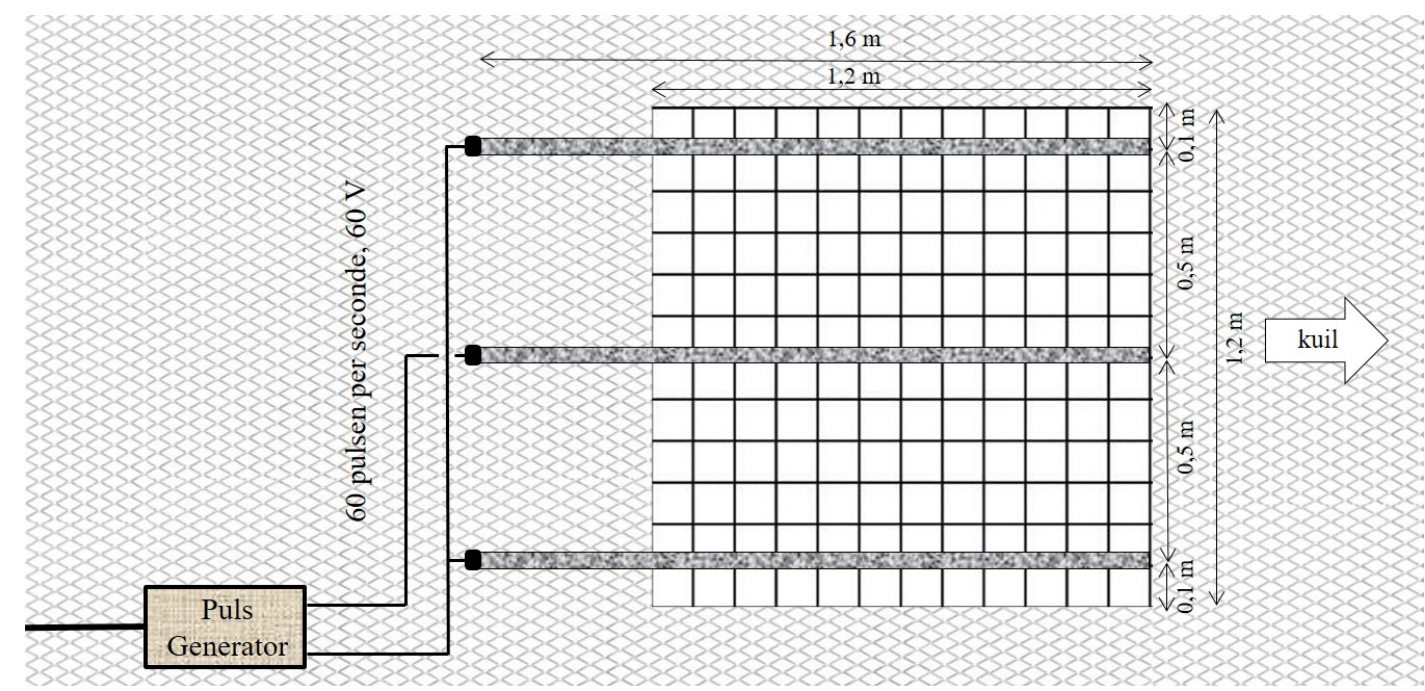

Figuur 3. Tekening van de eBRP configuratie getest op de TX36

De TX36 vist met pulswings met broeknetten (net met twee staarten en kuilen) zoals afgebeeld in foto 1 van het reisverslag (bijlage 1). In de pulswing aan bakboord werd in één staart (binnenzijde) een elektrisch 
benthos ontsnappingspaneel gestoken. Voorafgaand aan de reis werd hier reeds een 9-tal weken mee gevist waarin de vele, hier niet nader gespecificeerde technische uitdagingen van dit extra puls systeem in het net overwonnen werden. Op het einde van deze testperiode werkte beide eBRP's naar behoren en werd geen duidelijk verlies van maatse tong waargenomen in vergelijking met de standaard broeknetten aan de stuurboord pulswing.

\subsubsection{Monstername}

De waarnemersreis was van 22 t/m 27 oktober 2017 in de regio rond de Falls (Figuur 4) en het verloop wordt beschreven in het reisverslag. Om variatie te minimaliseren en de volledige vangst te kunnen analyseren werd besloten om beide staarten van eenzelfde vistuig met elkaar te vergelijken. Voordat de vergelijking heeft plaatsgevonden is het paneel eerst afgedekt met een stuk netwerk, in deze trekken is vergeleken of beide kuilen van het bakboord net gelijkwaardig visten (nultrekken). Voor de monstername werden beide kuilen afzonderlijk opgevangen d.m.v. een tussenschot in de stortbak (Figuur 5). Indien het weer het toeliet werden beide kuilen ook afzonderlijk gewogen met de unster van CIV Texel. Echter, in sommige gevallen bleken de uitgestorte volumes niet overeen te komen met de gemeten gewichten, mogelijk omdat een deel vangst achter de strop was blijven zitten. In dat geval werd de gewichten niet gebruikt om de discardresultaten op te schalen en werd de vangstanalyse beperkt tot het tellen en meten van de tongen.

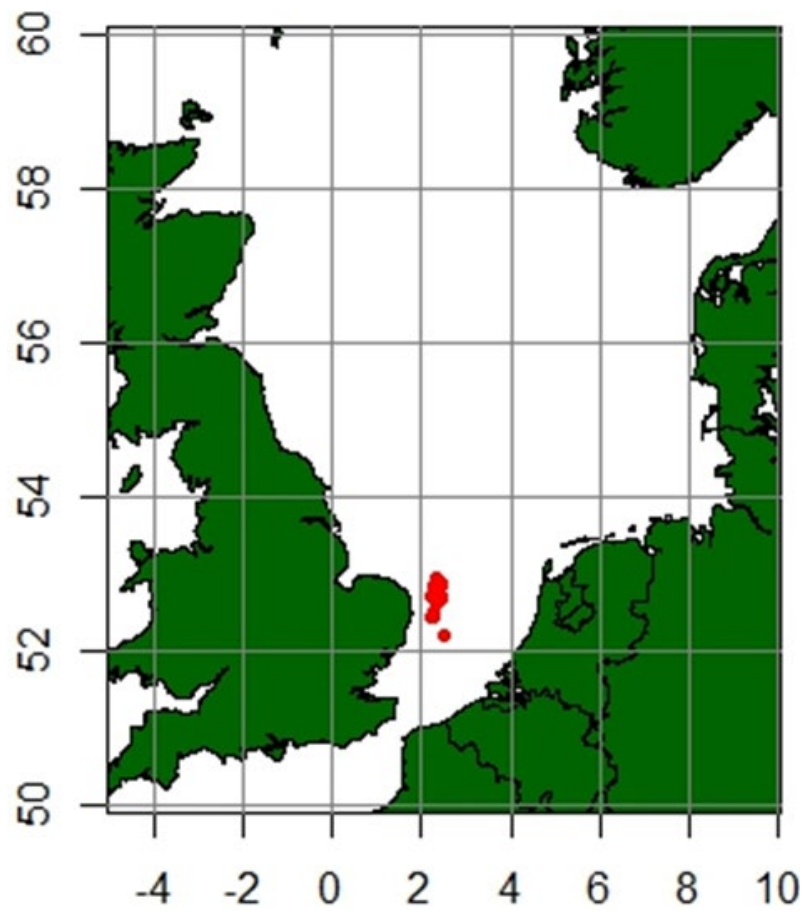

Figuur 4. De door de TX36 beviste locaties tijdens de reis.

Alle maatse tongen werden apart gehouden door de bemanning. De totale vangst per zijde werd gewogen en vervolgens werden alle tongen geteld en gemeten. Indien de gewichten van de beide kuilen betrouwbaar geacht werden omdat ze overeenkwamen met de gemeten vangstvolumes, werden ook een discard monster genomen. Voor de bemonstering van de discards werd afwisselend van beide sorteerbanden monsters genomen met een emmer die uitgestort werden in een mand (50 Liter) zodat een zo homogeen mogelijk monster van de discards verkregen werd. De mand discards werd gewogen en gesorteerd waarbij enerzijds tong, schol, schar, kabeljauw, wijting, steenbolk, rog afzonderlijk gewogen werden en anderzijds het gewicht van resterende vis (o.a. hondshaai, poon en mul) en restfractie (benthos en stenen) werd bepaald. Echter, de hoeveelheden discards van ondermaatse tong, schol en rondvis waren gedurende de hele reis gering. 


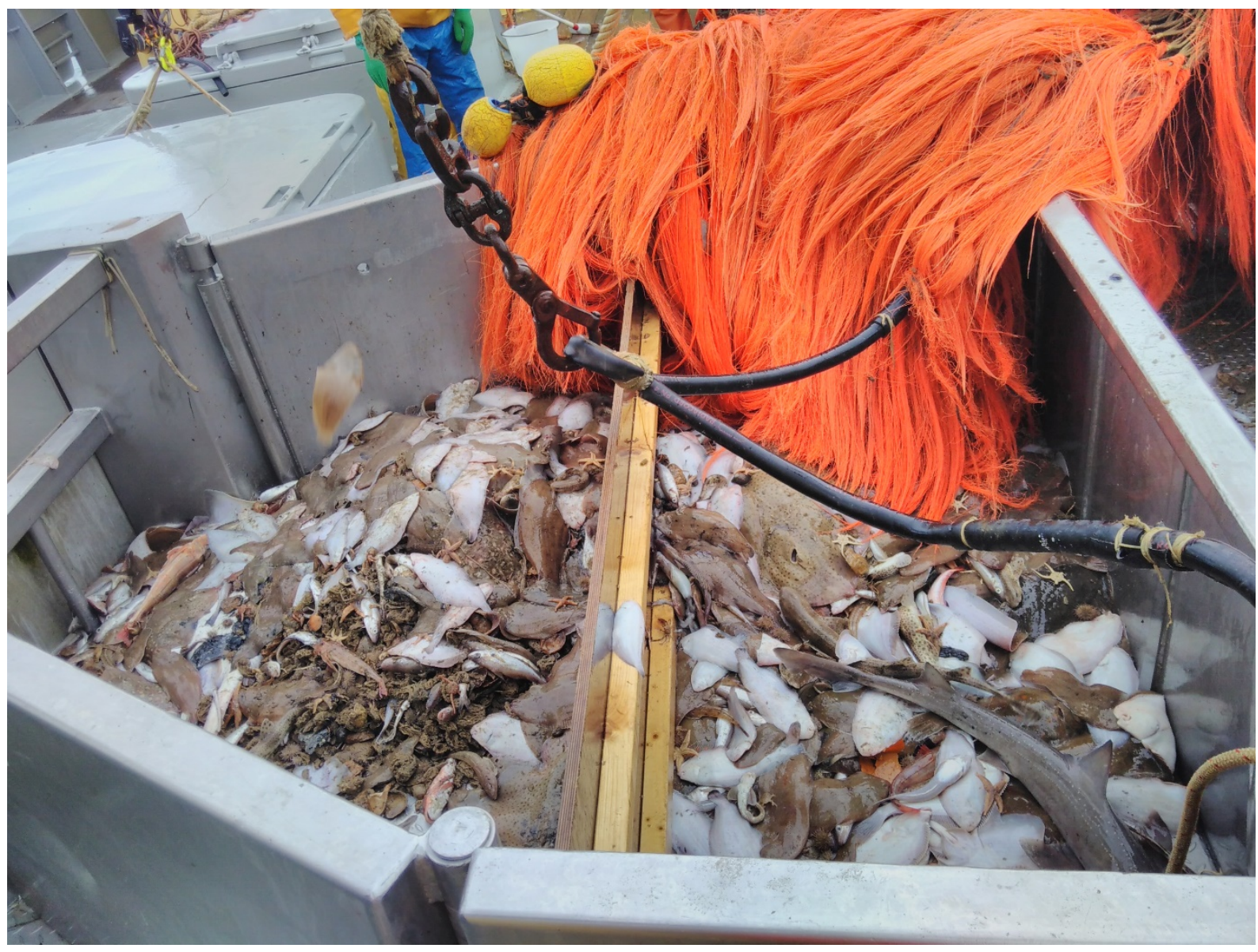

Figuur 5. Foto van de stortbak aan bakboord met het gebruikte tussenschot. De vangst links van het schot is afkomstig van het binnenste net, de vangst rechts ervan van het buitenste (referentie)net.

\subsubsection{Resultaten}

De totale vangstgewichten van de trekken die betrouwbaar konden gemeten worden tonen aan dat ongeveer $9 \%$ van het totaal volume geloosd werd door het paneel en dat terug te leiden valt tot een reductie van $19 \%$ in benthos- en afvaldiscards (Tabel 3). 
Tabel 3. De vangstresultaten per configuratie voor de verschillende fracties. De vangsten worden gegeven in $\mathrm{kg}$, berekend als totaal over het aantal trekken aangegeven in (\# trekken) voor het net aan de binnenkant (experimenteel) en buitenkant (referentie) van de pulskor aan bakboord. Daarna wordt het procentueel verschil aangegeven berekend als (binnenkant-buitenkant)/buitenkant en de p-waarde van een gepaarde t-test. Resultaten $<0.05$ zijn significant (vetgedrukt).

\begin{tabular}{|c|c|c|c|c|c|c|}
\hline & & \# trekken & binnenkant (kg) & buitenkant (kg) & $\%$ verschil & p-waarde \\
\hline \multirow[t]{5}{*}{ nultrek } & Totale vangst & 4 & 920 & 880 & $4,5 \%$ & 0,182 \\
\hline & Benthos + afval & 4 & 436 & 399 & $9,3 \%$ & 0,627 \\
\hline & Gewicht tong (>MLS) & 9 & 274 & 288 & $-4,9 \%$ & 0,248 \\
\hline & Aantallen tong (>MLS) & 9 & 621 & 631 & $-1,6 \%$ & 0,697 \\
\hline & Totale vangst & 5 & 1840 & 1980 & $-7,1 \%$ & 0,300 \\
\hline \multirow{3}{*}{$\begin{array}{c}\text { eBRP } \\
\text { instabiel }\end{array}$} & Benthos + afval & 5 & 852 & 1020 & $-16,5 \%$ & 0,140 \\
\hline & Gewicht tong (>MLS) & 6 & 188 & 181 & $3,9 \%$ & 0,737 \\
\hline & Aantallen tong (>MLS) & 6 & 414 & 395 & $4,8 \%$ & 0,586 \\
\hline \multirow{4}{*}{ eBRP stabiel } & Totale vangst & 3 & 660 & 760 & $-13,2 \%$ & 0,477 \\
\hline & Benthos + afval & 3 & 294 & 389 & $-24,4 \%$ & 0,728 \\
\hline & Gewicht tong (>MLS) & 5 & 171 & 158 & $8,2 \%$ & 0,040 \\
\hline & Aantallen tong (>MLS) & 5 & 347 & 345 & $0,6 \%$ & 0,901 \\
\hline \multirow{4}{*}{ eBRP totaal } & Totale vangst & 8 & 2500 & 2740 & $-8,8 \%$ & 0,156 \\
\hline & Benthos + afval & 8 & 1146 & 1409 & $-18,7 \%$ & 0,128 \\
\hline & Gewicht tong (>MLS) & 11 & 359 & 339 & $5,9 \%$ & 0,322 \\
\hline & Aantallen tong (>MLS) & 11 & 761 & 740 & $2,8 \%$ & 0,697 \\
\hline
\end{tabular}

Het aantal kilogram maatse tong gevangen tijdens de nultrekken lag ongeveer $5 \%$ lager voor het net aan de binnenkant van het vistuig. Tijdens de testtrekken met een eBRP zien we het tegenovergestelde, namelijk een lichte verhoging van het aantal kilogram gevangen tong van 4 en $8 \%$ (Tabel 3 ). Hetzelfde patroon is te zien in het aantal tongen (Tabel 3) en in de lengte frequentieverdelingen (Figuur 6), zij het iets minder uitgesproken. De oorzaak van de grotere vangst van maatse tong in het net met eBRP, die in het geval van de trekken met een eBRP met stabiel pulsveld significant waren, is onduidelijk. Mogelijk is het een artefact als gevolg van het beperkt aantal trekken maar zou ook kunnen dat het een gevolg is van een betere doorstroming van het water in het net door eBRP en de kleinere en schonere vangst. 

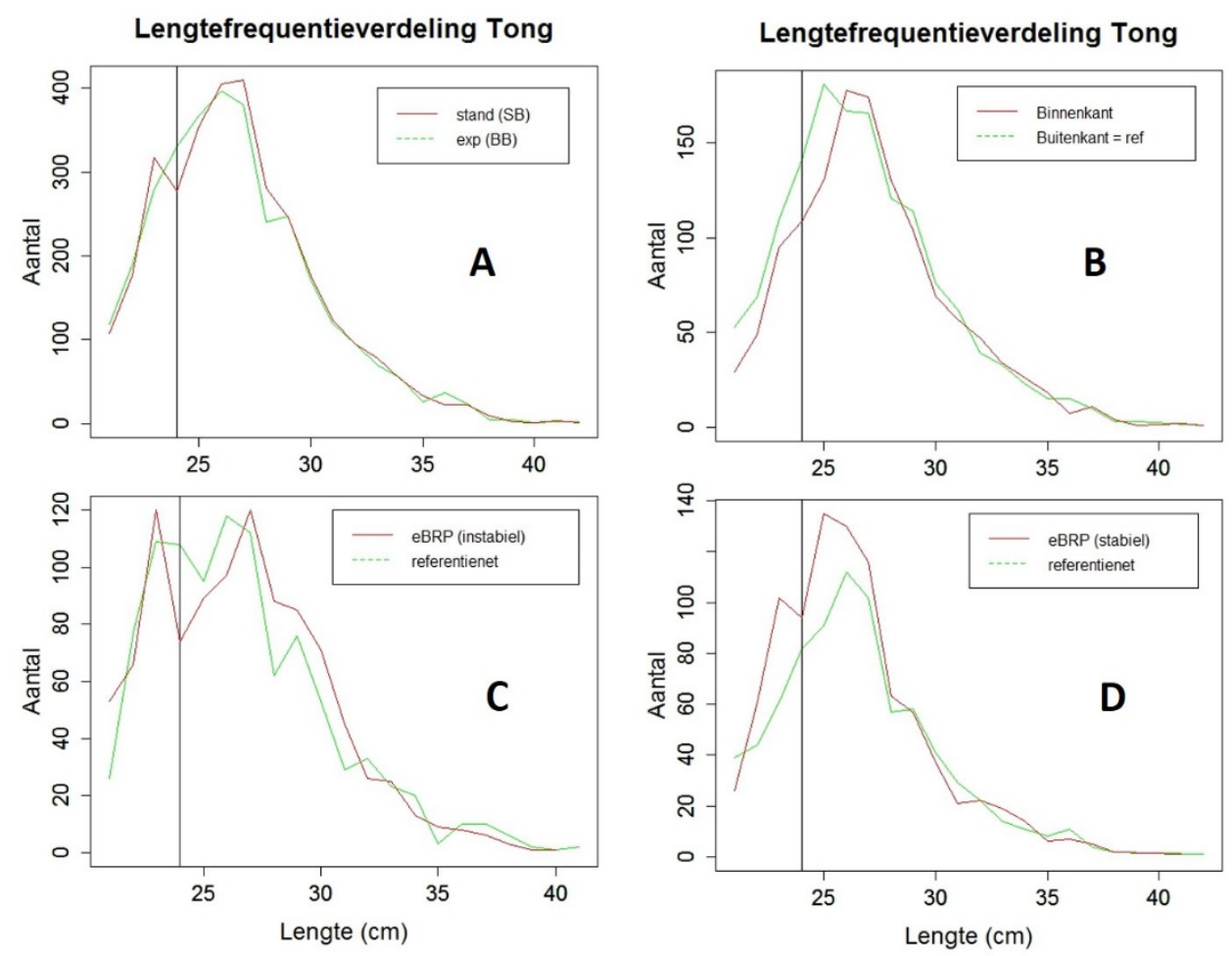

Figuur 6. De lengtefrequentieverdelingen (gevangen aantal per lengteklasse) voor tong over de gehele reis (A), tijdens de nultrekken (B), tijdens de trekken met eBRP en instabiele puls (C) en tijdens de trekken met perfect werkend eBRP (D).

De data met betrekking tot visdiscards is te beperkt variabel om onderbouwde conclusies te kunnen trekken. De oorzaak hiervan is viervoudig. Door pech zijn er slechts 5 trekken gebeurd en geanalyseerd met een correct werkend stabiel werkend eBRP systeem ('eBRP - stabiele puls') i.p.v. de beoogde 15. Daarnaast werden er in totaal 9 nultrekken verwerkt en 6 trekken met een eBRP met instabiele puls ('eBRP - niet stabiele puls') waarbij er foutmeldingen vanuit de pulsmodules op het paneel waargenomen zijn. Ten tweede konden niet voor alle trekken de discards verwerkt worden, waardoor per configuratie maximaal van 5 trekken de discardgewichten beschikbaar zijn. Ten derde waren de gevangen hoeveelheden ondermaatse rond- en platvis zeer beperkt, waardoor enkele individuen in een monster een zeer grote invloed hebben op de verhouding van de vangsten in beide netten en er een zeer grote variatie op de data zit. Tot slot waren er geen duidelijke consistente verschillen merkbaar tussen de beide vangsten waardoor mogelijke verschillen pas aangetoond kunnen worden met behulp van veel grote aantallen. Teneinde onder deze omstandigheden een zinvolle conclusie te kunnen trekken met betrekking tot de effecten op discards hadden minimaal 10 trekken per configuratie moeten uitgezocht zijn en hadden alle discards moeten uitgezocht worden i.p.v. een I. Louter ter indicatie geeft Tabel 4 het gemiddeld aantal kilo bijvangst voor rondvis en platvis per configuratie.

Tabel 4. Indicatief overzicht van het totaalgewicht aan discards in kg (gemiddelde $+\mathbf{s t d v})$ tijdens de uitgezochte trekken $($ trekduur $=$ $\pm 2 u u r)$. Het eBRP zat het net aan de binnenkant van het vistuig.

\begin{tabular}{|c|c|c|c|c|c|}
\hline \multirow[t]{2}{*}{ configuratie } & \multirow[t]{2}{*}{ \# trekken } & \multicolumn{2}{|c|}{ platvis } & \multicolumn{2}{|c|}{ rondvis } \\
\hline & & binnenkant & buitenkant & binnenkant & buitenkant \\
\hline nultrekken & 4 & $9,3 \pm 5,2$ & $16,0 \pm 11,1$ & $24,4 \pm 21,3$ & $21,3 \pm 12,2$ \\
\hline eBRP-instabiele puls & 5 & $24,2 \pm 7,6$ & $29,4 \pm 15,2$ & $65,4 \pm 22,6$ & $50,1 \pm 18,7$ \\
\hline eBRP-stabiele puls & 4 & $14,3 \pm 10,8$ & $15,4 \pm 11,6$ & $25,1 \pm 18,9$ & $25,5 \pm 21,8$ \\
\hline
\end{tabular}

\subsubsection{Conclusie}

Tijdens deze reis kregen we te maken met de nodige portie pech en visverlet waardoor het aantal trekken per configuratie beperkt was. Desondanks toont de bekomen data aan dat een eBRP zoals toegepast op de TX36 succesvol is in het lozen van bijgevangen benthos en stenen zonder verlies van maatse tong. De 
reducties in bijgevangen benthos en stenen waren echter aanzienlijk kleiner dan in vorige studies, wat hoogstwaarschijnlijk te wijten is aan enerzijds de reeds zeer beperkte hoeveelheden bijvangst van de licht opgetuigde pulswings van de TX36 en anderzijds van het feit dat het eBRP verder weg zat van de kuil waardoor een aanzienlijk deel van de vangst langs en niet over het paneel naar de kuil stroomt. Om dezelfde reden is het ook waarschijnlijk dat er minder tongen de kans hadden van te ontsnappen. De significant grotere vangsten van maatse tong in het net met eBRP en stabiele puls zijn opmerkelijk en onverwacht, maar meer trekken zijn nodig om dit resultaat te bevestigen en te kunnen inschatten of dit aan een verbeterde doorstroming van het net ligt of aan een andere reden.

Het effect op visdiscards kon niet onderzocht worden door een gebrek aan data, maar er waren geen aanwijzingen dat het gebruik van een eBRP tot noemenswaardige reducties leidde van ondermaatse platvis of rondvis en dus een mogelijk antwoord biedt op de aanlandingsplicht. Het toepassen van een kramppuls boven een eBRP immobiliseert de gevangen vissen ter hoogte van het paneel, ontsnapping van ondermaatse exemplaren door het paneel is daarom niet heel waarschijnlijk. Een eBRP lijkt voorlopig dus vooral een meerwaarde voor zwaarder vissende boom- of pulskorvaartuigen, waar het lozen van grote hoeveelheden benthos en stenen een significante verbetering kan betekenen voor de viskwaliteit en de selectiviteit in de kuil. Een verbetering in kwaliteit en dus de visconditie van de vissen zou ook een verbetering van de overleving van de discards kunnen beteken. Desalniettemin opende de ontwikkeling van pulsmodules die bruikbaar zijn in het net de poort naar een hele waaier nieuwe mogelijkheden om tot een verbeterde scheiding en/of selectiviteit te komen in de staart van het net.

\subsection{Touwtjes paneel}

\subsubsection{Beschrijving touwtjes paneel}

De eerste versie van het touwtjes paneel had een totale lengte van 8.5 meter en bestond uit stroken netwerk met daartussen vier secties van 1.5 meter met Dyneema touwen. Deze touwen staan $4 \mathrm{~cm}$ uit elkaar in de voorste twee secties touwen, en $2 \mathrm{~cm}$ uit elkaar in het achterste twee secties touwtjes van het paneel (zie tekening bijlage 2 en Figuur 7). De voorzijde van het paneel was 1 meter achter de onderpees van het pulsnet bevestigd en liep schuin omhoog richting de kuil eindigend in een tweede $80 \mathrm{~mm}$ kuil.

Om het paneel goed in het net te maken is er één achternet van de TX36 in de nettenschuur van Jaap Vlaming (JV Visserijconsultant) voorzien van het scheidingspaneel. Vrijdag 29 juni 2018 is het paneel met achternet bevestigd aan het broeknet (net met twee achtereinden) van de TX36, waarna er maandag 2 tot 6 juli op zee getest is met het paneel.

Om meer ruimte in het net te krijgen zijn er twee drijvers en een 'vlieger' aan de bovenzijde van het net bevestigd, hier zijn na de $2 \mathrm{e}$ trek nog twee drijvers (11ltr) bijgezet. Dit bleek de werking van het paneel niet ten goede te komen. Omdat de vlieger het net te ver omhoog trok is deze later weer verwijderd. Er is geprobeerd om te vissen met twee drijvers (11ltr) onder het paneel, dit had als resultaat dat bijna de gehele vangst in de onderkuil terecht kwam. 


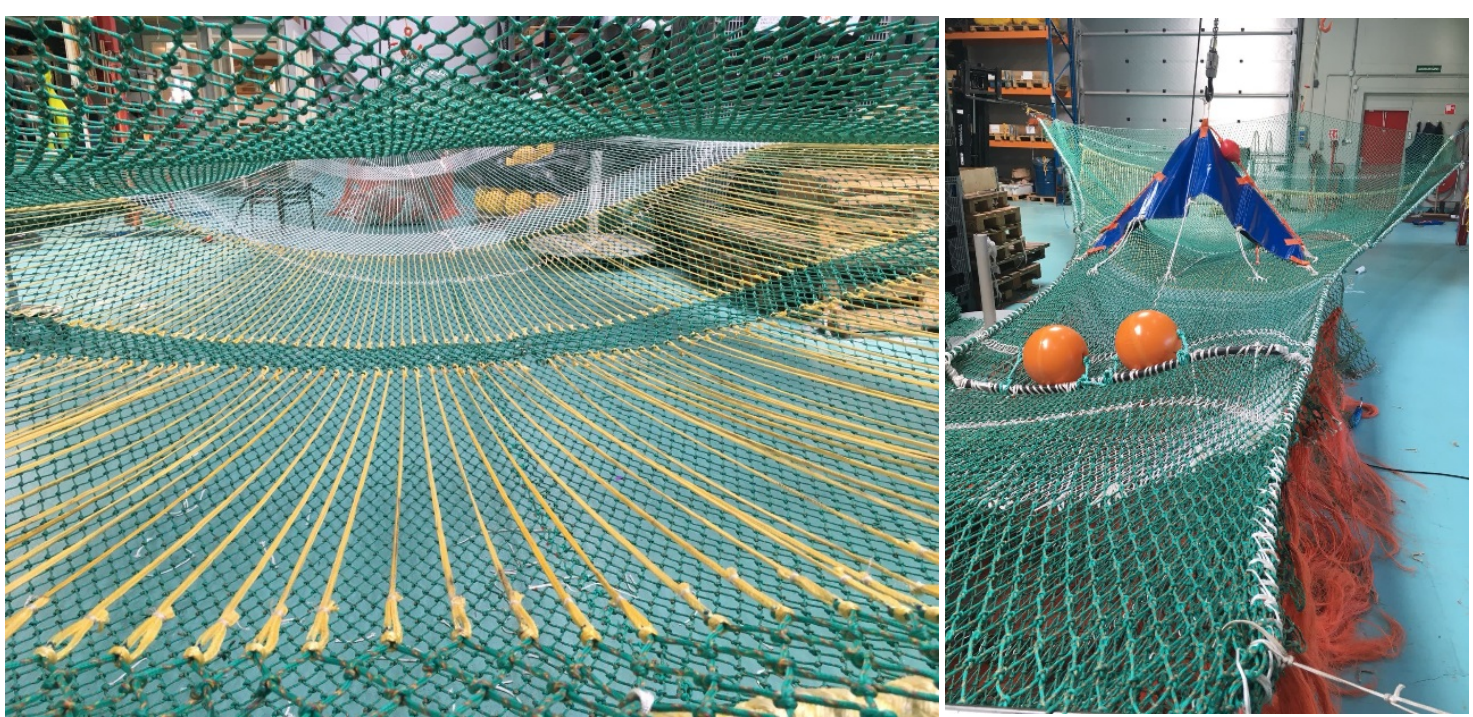

Figuur 7, Touwtjes paneel (gele \& witte) touwtjes linker foto, rechts het achternet met twee drijvers en een vlieger om extra hoogte te creëren in de bovenzijde van het net.

\subsubsection{Resultaten self-sampling}

In week 27 van 2018 heeft de TX36 een halve visweek met het touwtjespaneel getest. Er zijn 16 trekken met het paneel gedaan en de effectiviteit van het paneel is bemonsterd op basis van een self-

samplingsprotocol. De totale vangst per kuil (marktwaardige vis en discards) is geschat. De vangst is per kuil apart verwerkt en de marktwaardige vis is per soort gewogen. De resultaten zijn weergegeven in Tabel 5 en Figuur 8. Opvallend is dat de eerste 4 trekken het ruim twee keer zo veel vangst in de bovenkuil aangetroffen werd. Dit is ook terug te zien in de tong en schol vangsten waarvan rond de $80 \%$ in de bovenkuil gevonden werd. Na enkele aanpassingen aan het liftend vermogen van de vlieger en drijvers op het achternet wordt ongeveer de helft van de vangst gescheiden door het paneel, opnieuw wordt ook ongeveer de helft van de tong en schol in de bovenkuil gevonden. Voor trek 14 en 15 is er drijfvermogen onder het paneel gezet, hierdoor komt het paneel omhoog passeert zowel de marktwaardige tong als schol het paneel waardoor 80 tot $90 \%$ in de onderkuil in de onderkuil aangetroffen werd. 
Tabel 5. Resultaten self-sampling touwtjespaneel in week 27 van 2018 . Per kuil zijn weergegeven de totale vangst (aanlandingen en discards), marktwaardige tong $(>24 \mathrm{~cm})$, marktwaardige schol $(>27 \mathrm{~cm})$ in kilogram per trek. Daarnaast zijn de opmerkingen en netaanpassingen per trek weergegeven.

\begin{tabular}{|c|c|c|c|c|c|c|c|}
\hline & Onderkuil & & & Bovenkuil & & & \\
\hline Trek & $\begin{array}{l}\text { Vangst } \\
\text { totaal (kg) }\end{array}$ & $\begin{array}{c}\text { Tong } \\
\text { maats } \\
(\mathrm{kg})\end{array}$ & $\begin{array}{c}\text { Schol } \\
\text { maats } \\
(\mathrm{kg})\end{array}$ & $\begin{array}{l}\text { Vangst } \\
\text { totaal (kg) }\end{array}$ & $\begin{array}{c}\text { Tong } \\
\text { maats } \\
\text { (kg) }\end{array}$ & $\begin{array}{c}\text { Schol } \\
\text { maats } \\
(\mathrm{kg})\end{array}$ & Netaanpassingen / opmerkingen \\
\hline 1 & 40 & 1 & 9 & 90 & 4 & 38 & \\
\hline 2 & 50 & 1 & 15 & 120 & 6 & 46 & \\
\hline 3 & 30 & 1 & 3 & 120 & 7 & 40 & Achteraan 2 grote blazen (10 liter) bovenop rubber erbij \\
\hline 4 & 40 & 2 & 16 & 100 & 3 & 27 & 5 kleine blaasjes ( $800 \mathrm{gram}$ ) onder paneel gezet op de helft \\
\hline 5 & 100 & 2 & 23 & 90 & 2 & 24 & Vlieger er af gehaald/wel met 4 ballen \\
\hline 6 & 120 & 2 & 20 & 120 & 3 & 42 & Zonder vlieger met 4 grote ballen op rubber \\
\hline 7 & 100 & 3 & 16 & 160 & 4 & 32 & 2 grote ballen eraf gehaald \\
\hline 8 & 80 & 4 & 16 & 120 & 6 & 21 & \\
\hline 9 & 100 & 3 & 18 & 80 & 4 & 21 & Zonder ballen op rubber, steentjes in onderkuil \\
\hline 10 & 120 & 3 & 17 & 80 & 3 & 18 & \\
\hline 11 & 80 & 3 & 16 & 120 & 4 & 45 & \\
\hline 12 & 100 & 3 & 8 & 80 & 3 & 10 & Onderkuil stenen en zeesterren, boven alleen zeester \\
\hline 13 & 180 & 11 & 64 & 20 & 1 & 14 & 2 grote ballen onder paneel voorlaatste stuk \\
\hline 14 & 170 & 11 & 48 & 20 & 2 & 10 & 2 grote ballen onder paneel voorlaatste stuk \\
\hline 15 & 160 & 4 & 19 & 160 & 5 & 30 & $\begin{array}{l}2 \text { grote ballen eraf en } 3 \text { kleine er voor terug, stenen in vangst beide kuilen, } \\
\text { dodemansduimen in bovenkuil }\end{array}$ \\
\hline 16 & 120 & 7 & 46 & 100 & 4 & 45 & 1e trek veel vis/box in de boven kuil \\
\hline Gemiddelde & 98 & 4 & 22 & 99 & 4 & 29 & \\
\hline SD & 52 & 3 & 16 & 39 & 2 & 13 & \\
\hline
\end{tabular}

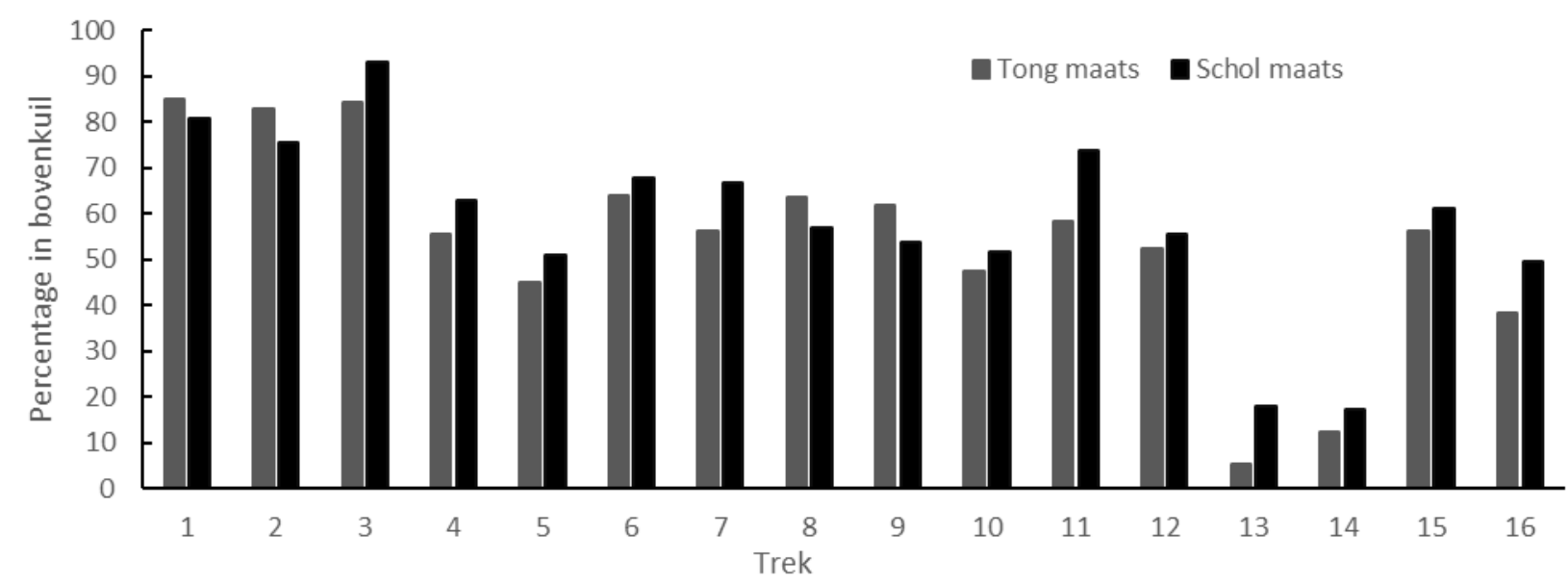

Figuur 8. Marktwaardige schol en tong aangetroffen in de bovenkuil. Uitgedrukt in percentage van de vangst per soort van onder en bovenkuil samen. Indien de scheiding van het paneel werkt zoals voorgesteld dan wordt $0 \%$ van de tong en $100 \%$ van de schol in de bovenkuil aangetroffen.

Op vrijdag 6 juli heeft de bemanning experimentele achternet met paneel vervangen door een conventioneel achternet. De deelnemende schipper en bemanning kwamen tot de volgende conclusie: "Het tongtouwtjespaneel werkt, maar nog niet voldoende tong is door het paneel gegaan. Er is eventueel een langer paneel nodig om de tong meer tijd te geven om door het paneel heen te kruipen. Nu hebben ze met een snelheid van 4.4 mijl over een lengte van 8 meter paneel ( 4 seconde) de tijd om er door te kruipen, dan is het nog best knap dat $50 \%$ van de tong door het paneel weet te kruipen. Eventueel moet er bij een vervolgtest één lang achternet met paneel komen in plaats van het huidige korte dubbele achternet." 


\subsubsection{Verlengt touwtjespaneel}

$\mathrm{Na}$ de eerste ervaringen met het touwtjes paneel is er een verlengde versie gemaakt van het touwtjes paneel. Omdat ongeveer de helft van de marktwaardige tong het paneel wist te passeren waren de betrokkenen van mening dat met een langer paneel een groter deel van de tong de kans kreeg om het paneel te passeren. Echter was het achternet van het broeknet van de TX36 te kort om het paneel nog verder te verlengen. $\mathrm{Er}$ is daarom besloten om de twee achter netten te vervangen voor één lang achternet waarin een langer paneel gemaakt kan worden.

Het touwtjes paneel is aan de voorzijde verlengt met een stuk netwerk met 400mm V-mazen waardoor het paneel een totale lengte heeft van 17.5 meter. De voorzijde van het paneel was 1 meter achter de onderpees gepositioneerd aan de onderzijde van het net, en liep naar achter schuin omhoog om $50 \mathrm{~cm}$ voor de kuil in de tweede kuil uit te komen. Het paneel was middels touwtjes aan de trekontlasters in de onderpees bevestigd, zodat de tong direct achter de onderpees eventueel al onder het paneel kon duiken. Het verlengde touwtjes paneel met het enkele achternet is in week 51 en 52 van 2018 getest op de TX36. De effectiviteit van het paneel is onderzocht middels self-sampling.

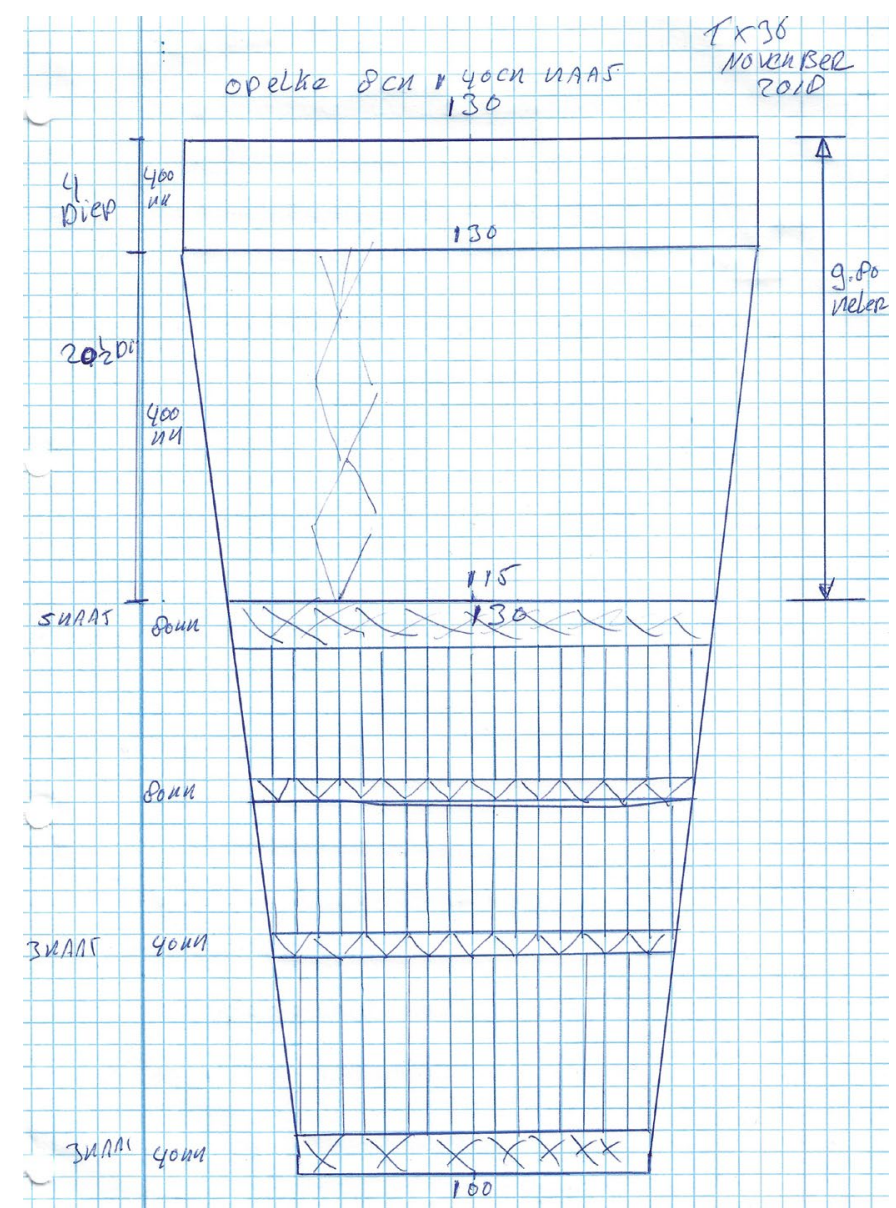

Figuur 9. Nettekening verlengt touwtjes paneel. De eerste sectie bestaat uit ruitvormige $400 \mathrm{~mm}$ mazen, daarna zijn er 3 secties met touwtjes. Tussen elke sectie is een stuk normaal netwerk gemaakt om de vorm van het paneel te behouden. 


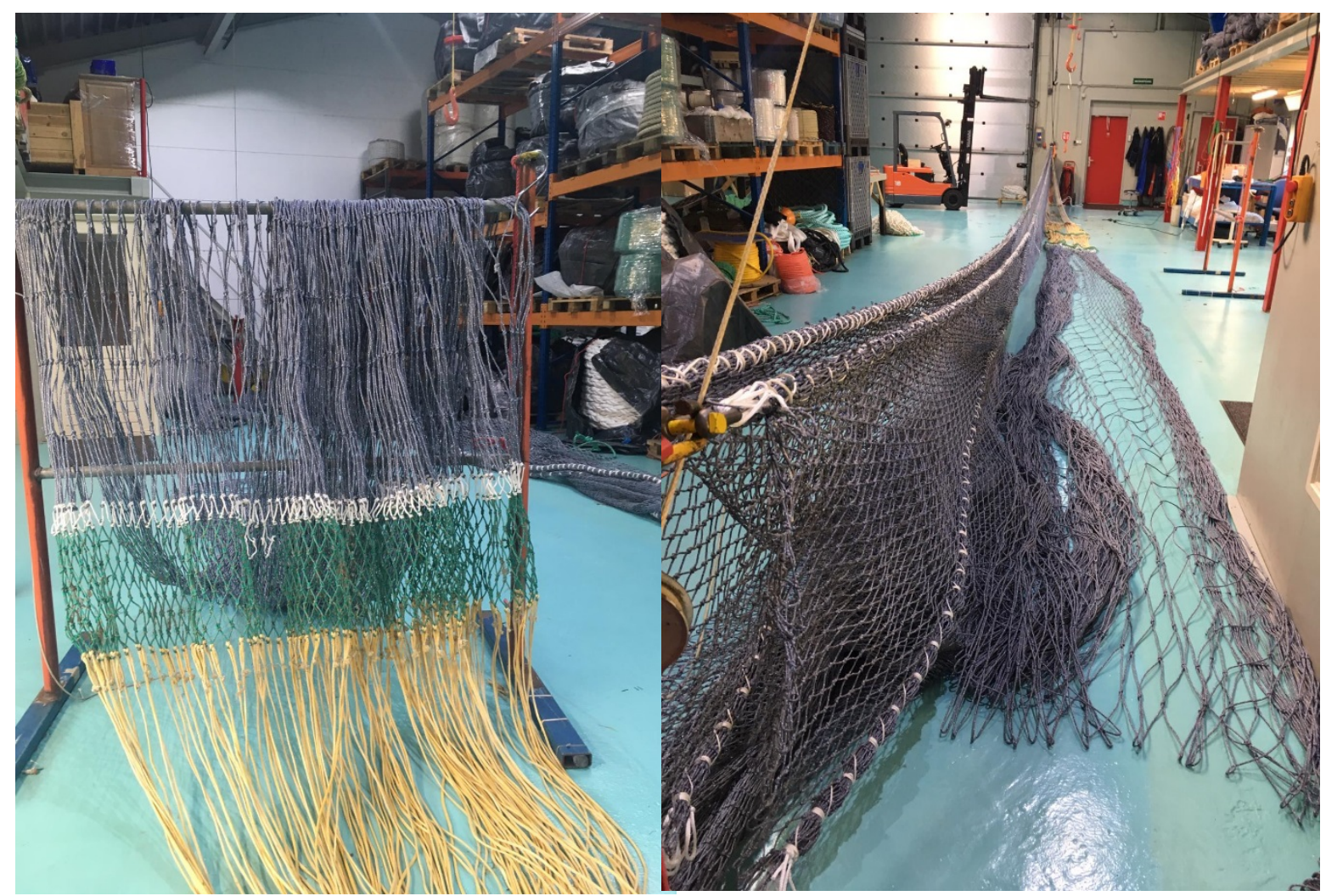

Figuur 10. Verlengt touwtjes paneel, in deze aangepaste versie is het paneel aan de voorzijde verlengt met een stuk $400 \mathrm{~mm}$ netwerk ( $\mathrm{V}$ maas) aan het paneel toegevoegd. Daarnaast is het gehele achternet langer gemaakt om de tong meer tijd te geven om door de mazen te kruipen.

Het idee voor het ontwerp touwtjes paneel is ontstaan naar aanleiding van beeldmateriaal wat vervaardigd is binnen het project 'Platvis in beeld' (Molenaar et al, 2018). Uit deze beelden bleek dat tong vaak op de bodem van het net gaat liggen en zoekt naar een uitgang. De andere (plat)vissen worden door de sterke stroming sneller naar achter in het net geleid. Het beoogde ontwerp van het tong touwtjes paneel maakt gebruik van de verschillen in gedragskenmerken van vissoorten waardoor ze door het paneel gescheiden worden en opgevangen kunnen worden in twee aparte kuilen.

De tong via het touwtjes paneel 'ontsnappen' naar de onderzijde van het net en komen daardoor in een aparte kuil terecht. De overige (plat)vis gaat over het paneel heen en komt in een aparte bovenkuil. Indien een effectieve scheiding bereikt is kan bij commerciële toepassing de onderkuil voor tong gemaakt worden van $80 \mathrm{~mm}$ netwerk en de bovenkuil van bijvoorbeeld $120 \mathrm{~mm}$ waardoor de bijvangst van ondermaatse schol en overige vissoorten aanzienlijk beperkt wordt. Echter dient eerst de werking van het paneel onderzocht te worden door de vangst op te vangen in twee kuilen met een gelijke maaswijdte $(80 \mathrm{~mm})$. Binnen Netinnovatie Kottervisserij 2 zijn er twee versies van het paneel getest.

\subsubsection{Resultaten verlengt touwtjespaneel}

Op 27 en 28 december 2018 heeft de TX36 getest met het verlengt touwtjes paneel in het bakboordnet. Er zijn totaal 12 trekken met het paneel bemonsterd, de resultaten zijn weergegeven in Tabel 6 en Figuur 11 . De eerste 2 trekken is er gevist met een vlieger op het achternet om te zorgen dat het achternet en paneel schuin omhoog zou lopen. Dit had niet het gewenste effect en het grootste deel van de vangst werd in de bovenkuil aangetroffen. Van de marktwaardige tong werd $30 \%$ gescheiden en in de onderkuil gevonden, daarbij zat $70-90 \%$ van de schol in de bovenkuil. Door de tegenvallende tongscheiding is na de $2^{\mathrm{e}}$ trek de vlieger verwijderd. Opvallend is dat ondanks het langere paneel er gemiddeld $141 \mathrm{~kg}$ per trek in de bovenkuil gevangen werd, tegen $104 \mathrm{~kg}$ in de onderkuil. Van trek $6 \mathrm{t} / \mathrm{m} 14$ werd ruim de helft van de marktwaardige tong in de bovenkuil gevonden, voor schol was dit tussen de 10 en 30\%. Door het verlengen van het touwtjespaneel kan een groter deel van de vis markwaardige tong en schol het paneel passeren, echter is een volledige scheiding van tong en schol nog niet bereikt. Na de $14^{\mathrm{e}}$ trek is er daarom besloten om het paneel weer uit het net te verwijderen. 
Tabel 6. Resultaten self-sampling touwtjespaneel in week 51 van 2018. Per kuil zijn weergegeven de totale vangst (aanlandingen en discards), marktwaardige tong $(>24 \mathrm{~cm})$, marktwaardige schol $(>27 \mathrm{~cm})$ en overige marktwaardige vissoorten in kilogram per trek. Daarnaast zijn de opmerkingen en netaanpassingen per trek weergegeven.

\begin{tabular}{|c|c|c|c|c|c|c|c|c|c|}
\hline \multirow[b]{2}{*}{ Trek } & \multicolumn{4}{|l|}{ Onderkuil } & \multicolumn{4}{|l|}{ Bovenkuil } & \multirow[b]{2}{*}{ Netaanpassingen / opmerkingen } \\
\hline & $\begin{array}{c}\text { Vangst } \\
\text { totaal } \\
\text { (kg) }\end{array}$ & $\begin{array}{c}\text { Tong } \\
\text { maats } \\
(\mathrm{kg})\end{array}$ & $\begin{array}{l}\text { Schol } \\
\text { maats } \\
(\mathrm{kg})\end{array}$ & $\begin{array}{l}\text { Overige } \\
\text { vis }(\mathrm{kg})\end{array}$ & $\begin{array}{c}\text { Vangst totaal } \\
(\mathrm{kg})\end{array}$ & $\begin{array}{c}\text { Tong } \\
\text { maats } \\
(\mathrm{kg})\end{array}$ & $\begin{array}{c}\text { Schol } \\
\text { maats } \\
(\mathrm{kg})\end{array}$ & $\begin{array}{l}\text { Overige } \\
\text { vis }(\mathrm{kg})\end{array}$ & \\
\hline 1 & 18 & 4 & 3 & 10 & 105 & 9 & 23 & 10 & \\
\hline 2 & 53 & 7 & 5 & 13 & 105 & 17 & 15 & 12 & Vlieger eruit gesneden na het halen \\
\hline 3 & 35 & 4 & 1 & 10 & 158 & 23 & 24 & 10 & Zonder vlieger. Na het halen touwtje losgesneden \\
\hline 4 & 88 & 13 & 6 & 7 & 175 & 25 & 17 & 7 & \\
\hline 5 & 105 & 5 & 6 & 1 & 193 & 18 & 19 & 2 & Een deel van paneel uitgesneden en nieuw stuk ingeregen \\
\hline 6 & 175 & 20 & 6 & 6 & 210 & 18 & 33 & 7 & \\
\hline 9 & 210 & 34 & 8 & 7 & 210 & 19 & 18 & 5 & \\
\hline 10 & 175 & 23 & 6 & 2 & 175 & 28 & 14 & 3 & \\
\hline 11 & 105 & 28 & 5 & 4 & 105 & 24 & 9 & 3 & \\
\hline 12 & 88 & 23 & 4 & 4 & 70 & 18 & 18 & 4 & \\
\hline 13 & 88 & 21 & 2 & 6 & 70 & 26 & 13 & 7 & \\
\hline 14 & 105 & 23 & 5 & 4 & 123 & 28 & 13 & 5 & \\
\hline Gemiddeld & 104 & 17 & 5 & 6 & 141 & 21 & 18 & 6 & \\
\hline SD & 58 & 10 & 2 & 4 & 51 & 6 & 6 & 3 & \\
\hline
\end{tabular}

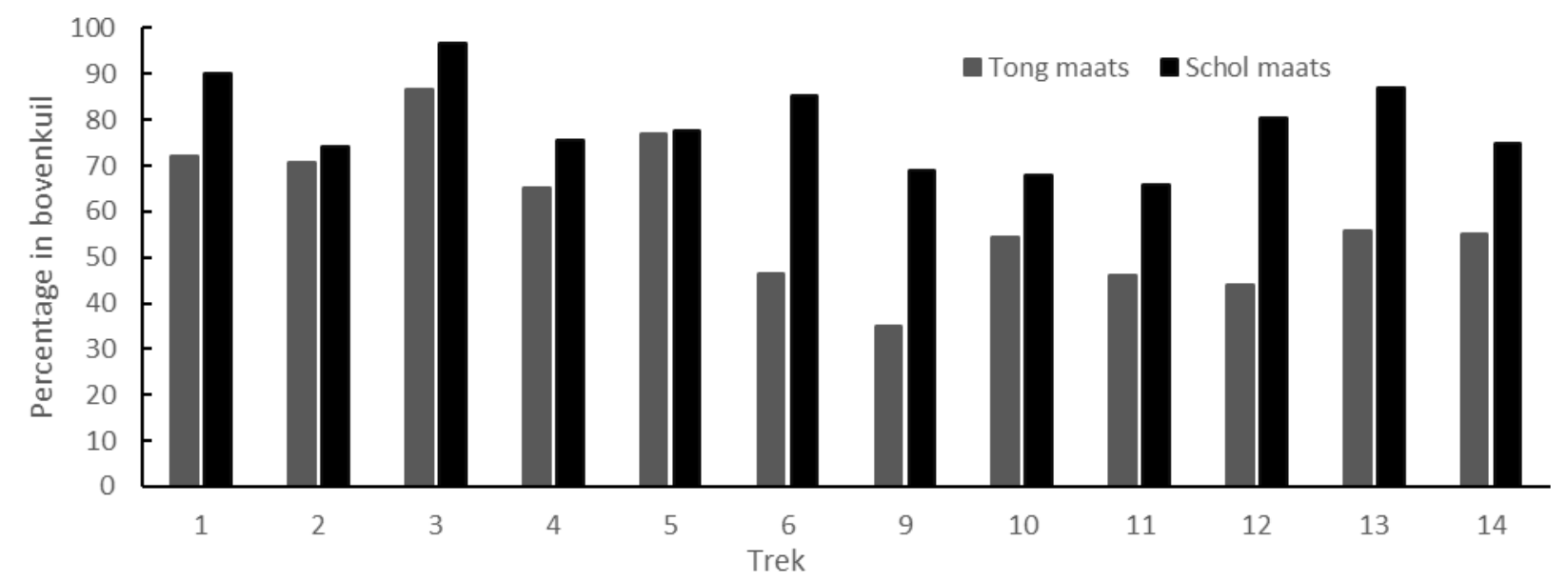

Figuur 11. Marktwaardige schol en tong aangetroffen in de bovenkuil. Uitgedrukt in percentage van de vangst per soort van onder en bovenkuil samen. Indien de scheiding van het paneel werkt zoals voorgesteld dan wordt $0 \%$ van de tong en $100 \%$ van de schol in de bovenkuil aangetroffen.

\subsubsection{Conclusie touwtjespaneel}

Het touwtjespaneel was ontworpen om tong en schol te scheiden, het idee was om een paneel te maken in het net waar tong wel door heen zou gaan schol niet. Uit de testen zou dan moeten blijken dat een groot deel van de tong in de onderkuil, en schol in de bovenkuil aangetroffen werd. Het percentage dan van elke soort in de boven of onderkuil aangetroffen wordt, moet dan een groot verschil tonen. Dit was echter niet het geval. In de eerste versie was er variatie tussen de trekken in de hoeveelheid tong en schol die in de bovenkuil aangetroffen werd, maar binnen de trekken was het percentage voor schol en tong nagenoeg gelijk (Figuur 8). Voor het verlengde touwtjespaneel werd echter wel een groter verschil in de percentages tussen de soorten waargenomen (Figuur 11), waarbij ruim 70\% van de schol in de bovenkuil gevonden werd. Opvallend is dat tong het paneel in deze trekken $(6 \mathrm{t} / \mathrm{m} 14)$ beter weet te passeren dan schol. Echter is dit niet voldoende om dit paneel commercieel toe te passen omdat bij het vergroten van de maaswijdte van de bovenkuil naar $120 \mathrm{~mm}$ zou in deze configuratie $40 \%$ van de marktwaardige tong ontsnappen. Een vervolg zou zich kunnen focussen op het optimaliseren van de passeerbaarheid van het paneel voor tong. Onderwateropnames op het paneel tijdens het vissen leveren mogelijk belangrijke nieuwe inzichten op die voor deze optimalisatie gebruikt kunnen worden. 


\subsection{Pulse selector}

De pulse selector is gebaseerd op het scheiden van tong en overige vis vóór de onderpees van het net. De gedachte achter dit ontwerp is dat deze scheiding plaats vindt door verschillende gedragskenmerken van vissoorten bij naderend gevaar. Het idee is dat tong zich ingraaft voor het naderend gevaar van bijvoorbeeld een onderpees of borstelpees. Overige (plat)vissen vertonen deze reactie niet of in mindere mate waardoor ze voor het naderende gevaar uit blijven zwemmen tot een bepaald stadium van vermoeidheid bereikt is en de vis door de onderpees wordt ingehaald en over de onderpees het net zal binnengaan. Hierdoor zou het theoretisch mogelijk zijn om de andere vis op te vangen vóórdat de tong elektrisch gestimuleerd wordt om de bodem te verlaten. Indien tong en overige vis gescheiden zijn kan de vis anders dan tong richting een ontsnappingspaneel geleid worden waar ondermaatse exemplaren kunnen ontsnappen. Een andere mogelijkheid is om deze overige vis anders dan tong op te vangen in een extra kuil, indien deze gemaakt is van netwerk van $120 \mathrm{~mm}$ kunnen ondermaatse individuen uit de deze extra kuil ontsnappen. Er zijn twee varianten van de Pulse selector getest, waarbij de eerste variant was gemaakt met een rubberpees met ontsnappingspanelen, en de tweede variant met een borstelpees en een extra kuil.

\subsubsection{Beschrijving Pulse selector}

De Puls selector bestond uit een V-vormige extra onderpees gemaakt van rubberen schrijven en een ketting, deze $\mathrm{V}$-vormige pees was bevestigd onder het midden van de wing. Tussen de $\mathrm{V}$-vormige onderpees en de bovenzijde van het net was $80 \mathrm{~mm}$ netwerk bevestigd. Het idee is dat de opgeschrikte vissen (anders dan tong) vóór het pulsveld naar de zijkant van het net geleid worden waar zich aan beide zijden van het net tot aan de grondpees een ontsnappingspaneel van $160 \mathrm{~mm}$ vierkanten (T45) mazen bevindt. Door dit paneel kunnen de ondermaatse vissen buiten het pulsveld ontsnappen zonder gedemobiliseerd te worden door de puls. Maatse vissen kunnen hier niet door heen en gaan over de grondpees alsnog het net in. Verwacht wordt dat tong niet reageert op de V-vormige onderpees en ingegraven blijft tot het pulsveld, waar deze elektrisch gestimuleerd wordt om de bodem te verlaten en over de tweede onderpees gevangen worden door het net. Een schematische tekening van het concept geeft het experimentele concept weer wat in de praktijk getest is (zie Figuur 12 \&Figuur 13). 

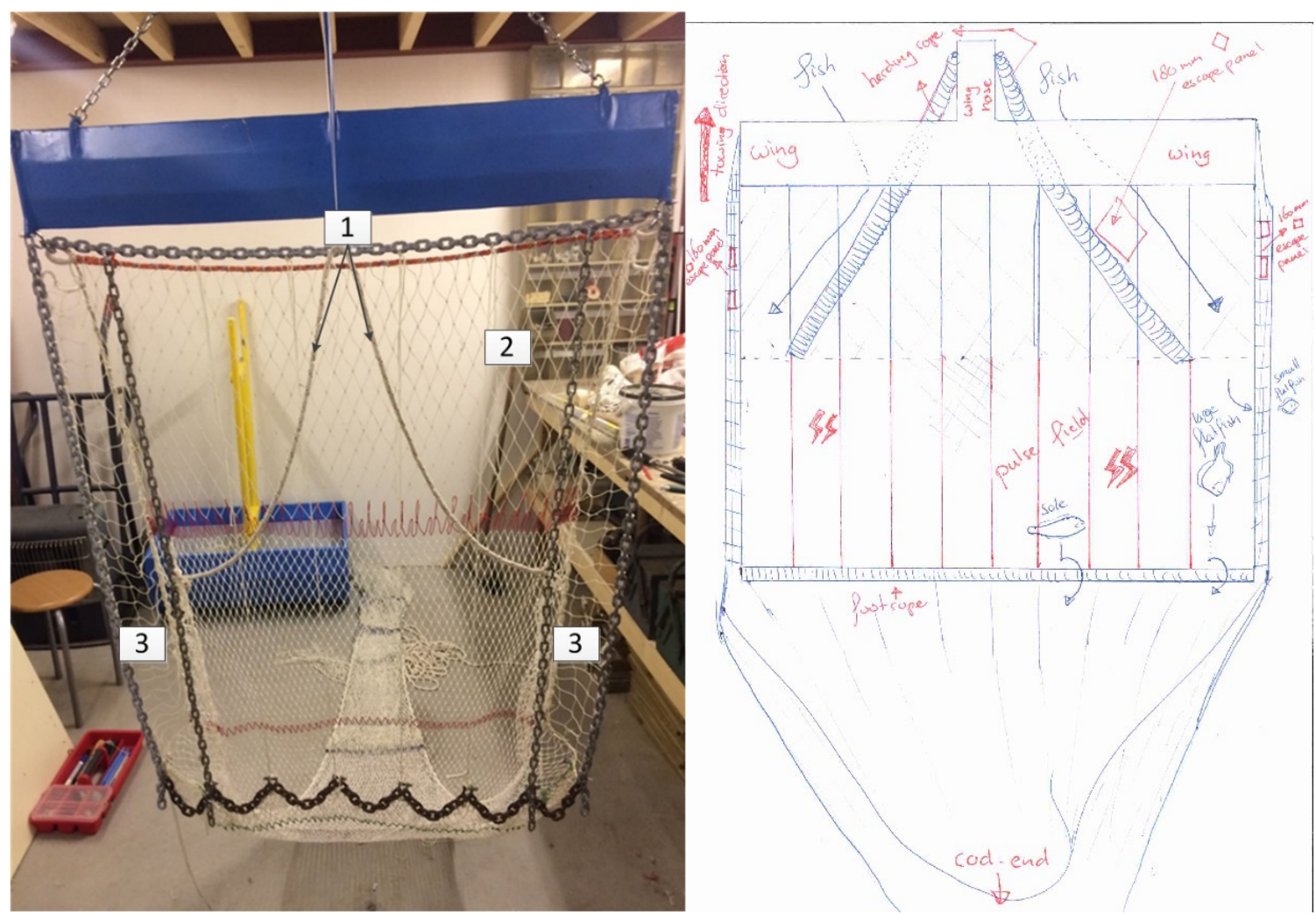

Figuur 12. Links een schaalmodel van de pulse selector met nummers met elementen uit de concepttekening. Rechts een tekening van het puls selector concept met waarbij de vis anders dan tong door een extra onderpees met netwerk (1) daarboven naar ze zijkant van het net geleid wordt. In de bovenkap van het net bevinden zich $180 \mathrm{~mm}$ T0 mazen (2) en in de zijkant van het net $160 \mathrm{~mm}$ T45 mazen (3) waardoor de ondermaatse vis kan ontsnappen. Na de extra onderpees wordt de tong in het pulsveld gestimuleerd om de bodem te verlaten waarna alle marktwaardige vis over de onderpees in het net terecht komt.

\subsubsection{Praktijkproef Pulse selector}

De Pulse selector betreft een innovatief tuig waarvan de werking in de praktijk nog niet bekend was, daarom is volgens het innovatiemodel (Figuur 1) een praktijktest gedaan door de BRA5. Van november 2017 tot december is er gewerkt aan het klaar maken van de tuigen, daarna heeft er een praktijkproef in de eerste week van januari 2018 plaatsgevonden.

Het experimentele Pulse selector tuig (Figuur 13) was in het stuurboordnet van de BRA5 gemaakt en effecten zijn vergeleken met het conventionele net aan de bakboordzijde van het schip. Er is gevist westelijk van Den Helder buiten de 12 mijl. In totaal zijn er 3 trekken gedaan met het experimentele net waarbij de aantallen marktwaardige tong per net geregistreerd zijn. Uit deze resultaten blijkt dat er een gelijk aantal of meer tongen gevangen werden in het tuig met de Pulse Selector (Tabel 7). Ondermaatse vis en bijvangsten zijn niet geregistreerd. Na het ophalen van de netten viel het op dat er vis en zeesterren vast zaten in het netwerk boven de extra V-vormige onderpees.

Tabel 7. Marktwaardige tongvangsten van Pulse selector en conventioneel pulsnet in aantallen per trek.

\begin{tabular}{cccc} 
Trek & $\begin{array}{c}\text { Mrekduur } \\
(\mathbf{m i n})\end{array}$ & Puls Selector $(\mathbf{s b})$ & Conventioneel net (bb) \\
\hline $\mathbf{1}$ & 40 & 25 & 16 \\
\hline $\mathbf{2}$ & 75 & 21 & 22 \\
\hline $\mathbf{3}$ & 90 & 50 & 43 \\
\hline
\end{tabular}

Uit de waarnemingen van de proef () blijkt dat op harde visgrond met de getijdenstroom mee vissend het tuig met de Pulse selector meer weerstand had en de koers van het schip 3 a 4 graden naar stuurboord trok. Tegen de getijdenstroom in was de extra weerstand dusdanig dat de kotter 0.4 mijl langzamer viste. Doordat de extra weerstand van het tuig in de eerste praktijdproef aanzienlijk was, is besloten om niet 
verder te experimenten met deze uitvoering. Zodoende is de v-vormige extra onderpees vervangen voor een lichte borstelpees. Deze versie van de Pulse Selector wordt beschreven in de volgende paragraaf.

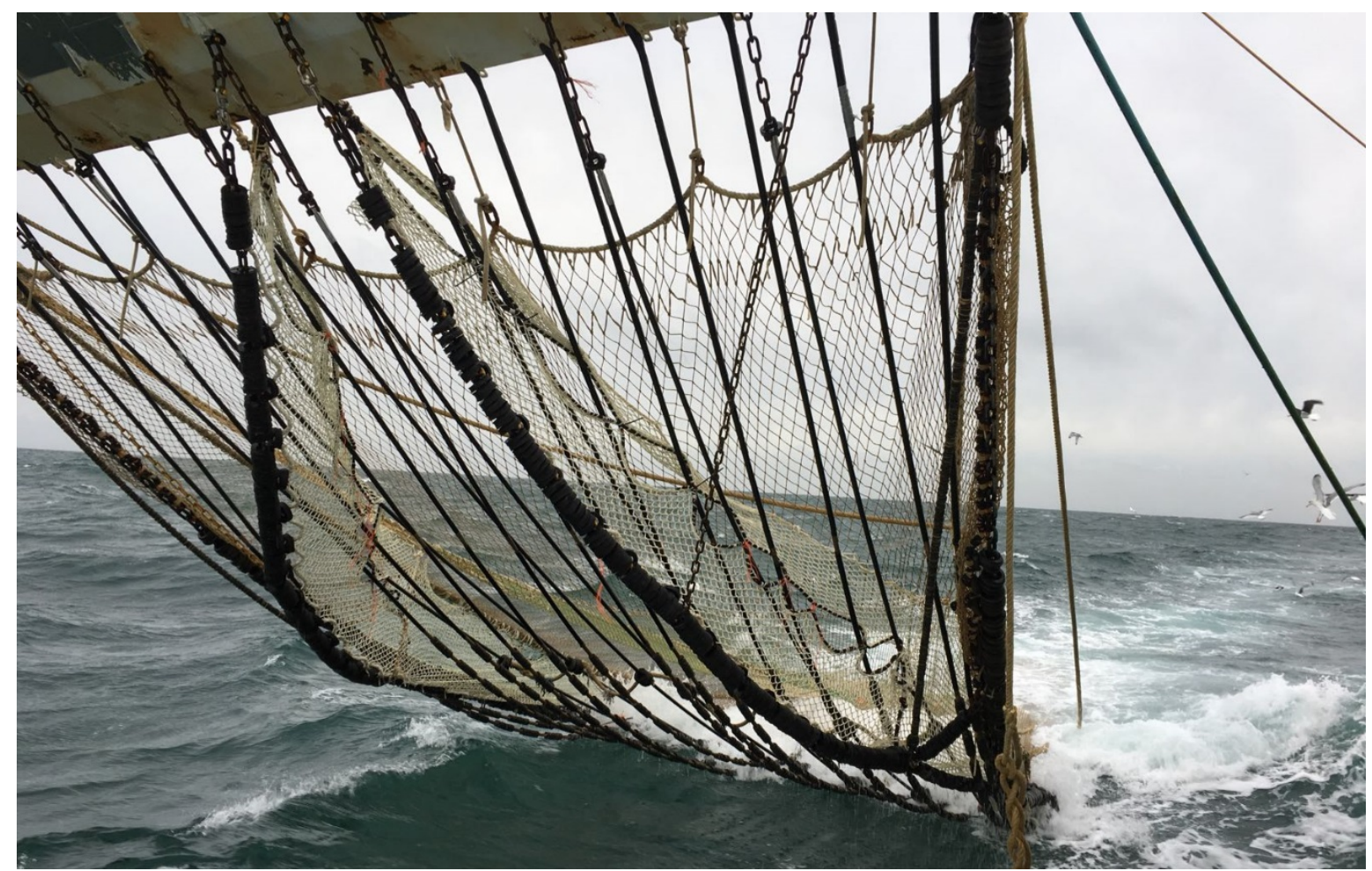

Figuur 13. Pulse selector in een 7 meter pulsnet met vanaf het midden van de wing bevestigde extra onderpees met netwerk dat de overige vis anders dan tong naar de zijkant van het net moet geleiden. Aan beide zijdes van het net zijn ontsnappingspanelen aangebracht met vierkante mazen.

\subsubsection{Pulse Selector met borstelpees}

Gezien de Pulse selector met rubberpees te veel extra weerstand gaf tijdens het vissen is er een tweede versie van het zelfde principe gemaakt. In deze tweede versie is het principe omgedraaid; het idee is dat de vis (anders dan tong) nu door een lichtere borstelpees (Figuur 14) nog vóór het pulsveld naar het midden van het net gedreven wordt. De specificaties van de borstelpees zijn weergegeven in Figuur 15. Aan het einde van de borstelpees bevindt zich een klein stukje extra onderpees waar de bijeengedreven vis opgeschrikt en opgevangen wordt in een extra tunnel die leidt naar een extra kuil. Deze kuil kan in een commerciële setting gemaakt worden van een grotere maaswijdte waardoor de marktwaardige vis opgevangen wordt en de ondermaatse vis kan ontsnappen.

$\mathrm{Na}$ de borstelpees en het begin van de extra kuil komt het elektrisch wekveld van het tuig, hier worden de tongen geprikkeld om de bodem te verlaten en worden vervolgens in een 'normale' $80 \mathrm{~mm}$ kuil opgevangen. 

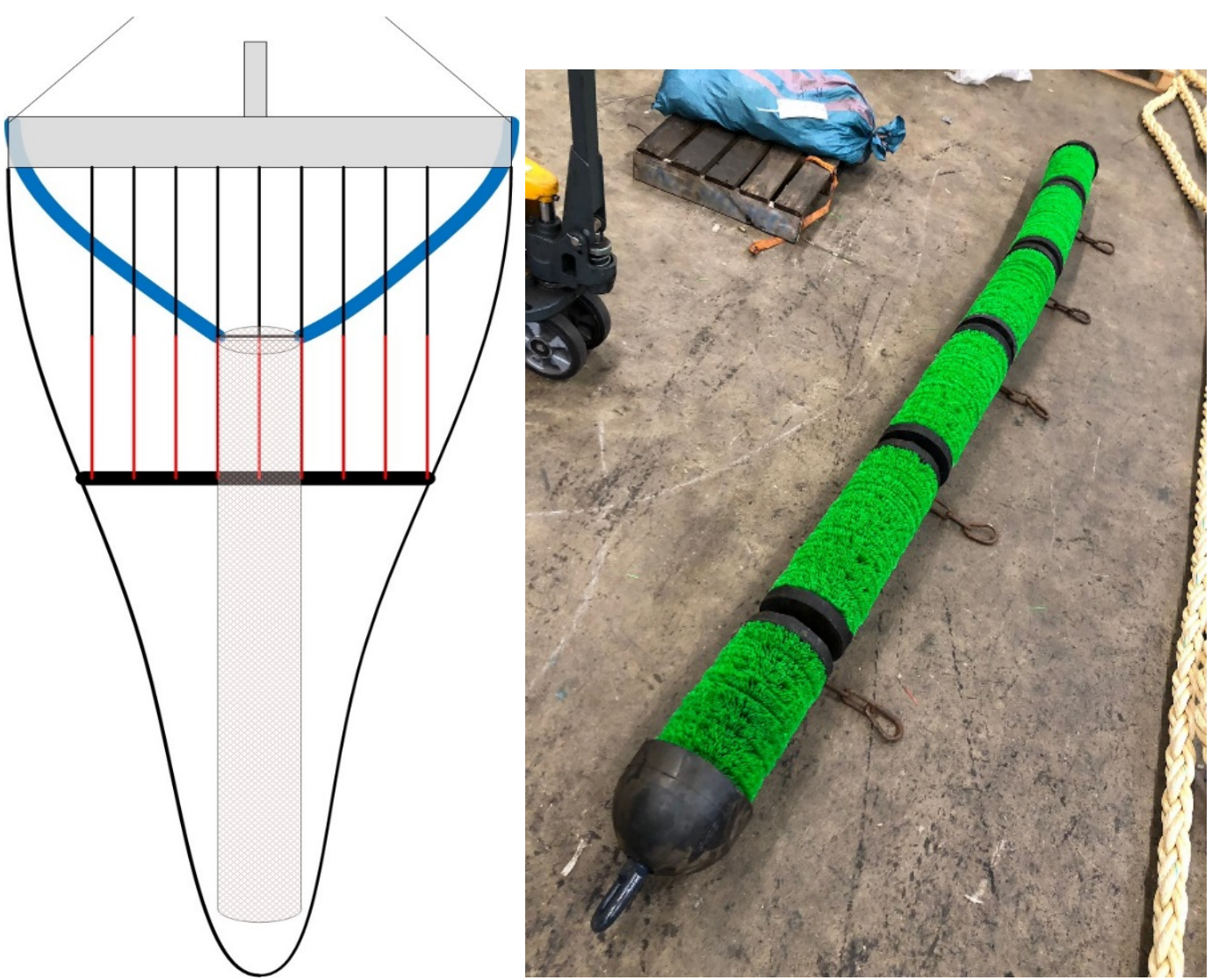

Figuur 14. Links de concept tekening van Pulse selector met in blauw de borstelpees welke de overige vis anders dan tong naar het midden van het net moet drijven waarna deze vis opgevangen wordt in een extra kuil. Rechts de borstelpees zoals gebruikt in de proef.

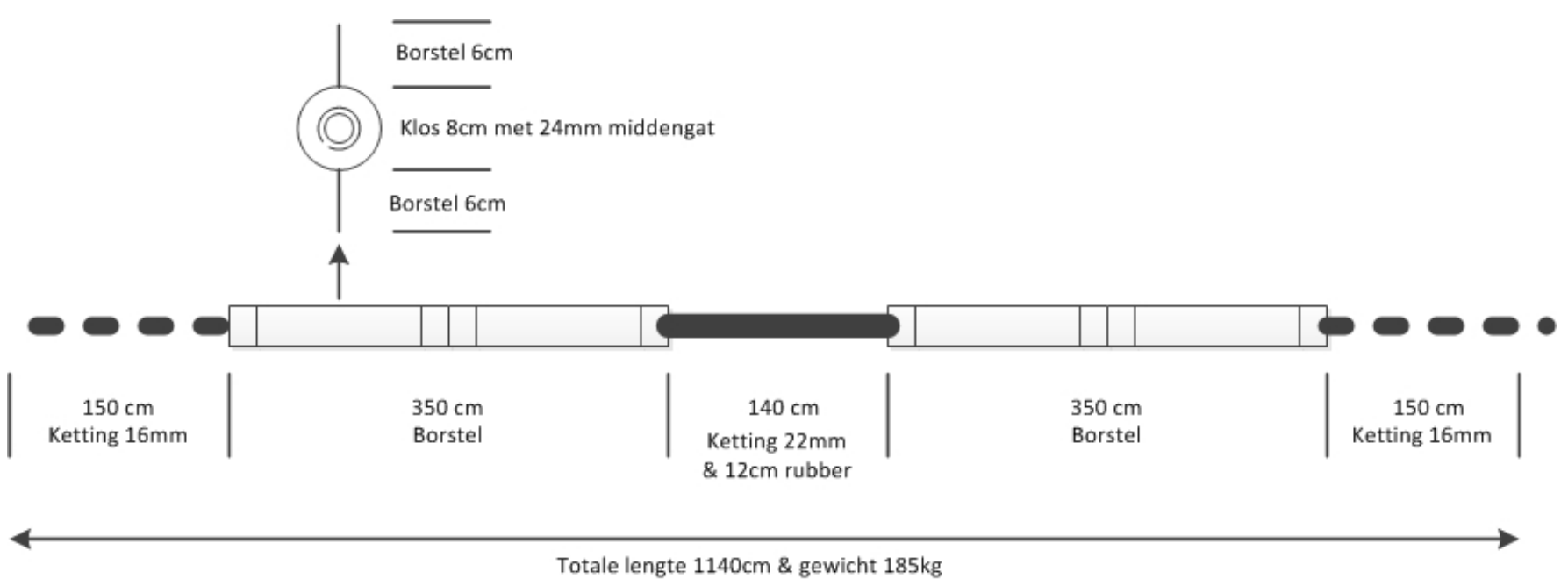

Figuur 15. Specificaties van de borstelpees van de Pulse selector

\subsubsection{Proefopzet pulse selector met borstelpees}

Voor de testen en onderzoeken van het effect van de borstelpees is er voor de extra kuil geen gebruik gemaakt van een grotere maaswijdte. Beide kuilen waren gemaakt van $80 \mathrm{~mm}$ netwerk waardoor er op basis van de vangsten in beide kuilen geanalyseerd kon worden welke vis door de borstelpees naar het midden geleid kon worden. De borstelpees was oorspronkelijk ontworpen voor het 7 meter brede tuig van de BRA5, de testen hebben echter plaatsgevonden op de BRA7 welke 7.8 meter brede tuigen heeft. Om de juiste vorm in de borstelpees te krijgen is er daarom aan beide uiteinden van de pees $150 \mathrm{~cm}$ ketting bevestigd (Figuur $15 \& 16$ ). 


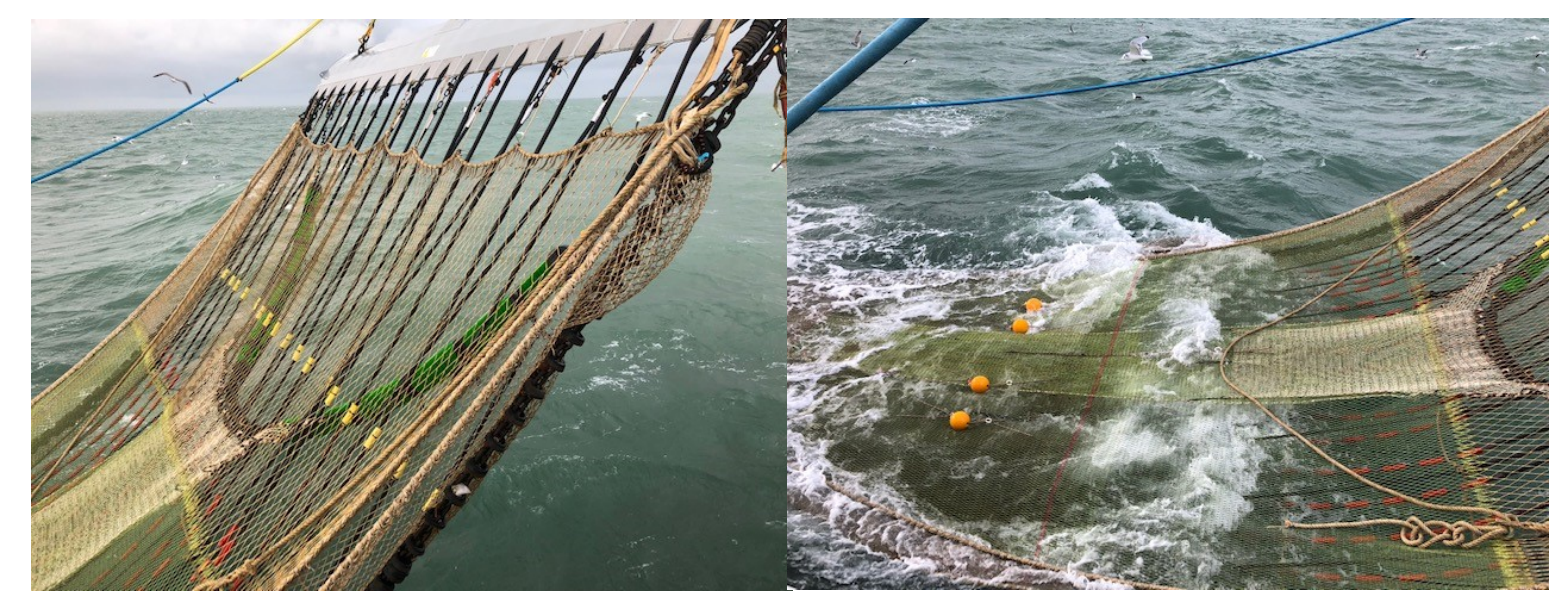

Figuur 16. Puls selector met borstelpees en extra tunnel zoals getest in december 2018.

\subsubsection{Praktijktest Puls selector met borstelpees}

Om een eerste indruk van de werking van de Pulse selector met borstelpees is er in de week 51 van 2018 experimenteel gevist met het tuig met de borstelpees en extra kuil aan de bakboordzijde van de BRA7. Er zijn 12 trekken met het experimentele tuig gedaan in "het gaatje van Ellen" waarbij er per trek in de normale kuil van het net een totale vangst van 120 tot $200 \mathrm{~kg}$ waarvan ongeveer $80 \mathrm{~kg}$ benthos en inert materiaal geschat werd. De eerste trek werd $20 \mathrm{~kg}$ kleine vis gezien in de extra kuil achter de borstelpees, de trekken daaropvolgend was dit 10 tot $15 \mathrm{~kg}$. Er werd geen verlies van marktwaardige vis ten opzichte van het conventionele net aan stuurboord waargenomen door de bemanning van de BRA7. Echter stond de extra tunnel welke achter de borstelpees de vis op moest vangen te strak in het net, dit heeft mogelijk gevolgen gehad voor de effectiviteit van het opvangen van vis die bij elkaar gedreven is door de bostelpees beïnvloed. Daarnaast begonnen de borstels niet direct aan beide uiteinden van de wing waardoor er mogelijk niet alle vis (anders dan tong) over de volledige breedte van het tuig bij elkaar gedreven is. Uit de trekkrachtmeters van beide vistuigen bleek dat de weerstand van het experimentele net nagenoeg gelijk was aan die van het conventionele net aan stuurboord.

De optuiging van de Puls selector was in deze eerste praktijktest nog niet optimaal, daarom moeten de resultaten met voorzichtigheid geïnterpreteerd worden. Er lijkt op basis van de eerste test geen vangstverlies op te treden, en een deel van de ondermaatse vis kan in een extra kuil gevangen worden. Een tweede test is aan te raden waarbij de borstels van de pees aan beide uiteinden verlengd worden en de extra tunnel beter in het net bevestigd wordt.

\subsection{Schanspaneel}

\subsubsection{Inleiding en beschrijving}

Het schanspaneel creëert een als het ware 'springschans' over de pulsmodules en het pulsveld. Het paneel bestaat uit een valse onderpees met scheidingspaneel in het net vóór het pulsveld in een pulstuig. Ook bij het schanspaneel wordt gebruik gemaakt van het idee om de doelsoort tong te scheiden van de overige vissoorten in de vangst. Hierbij wordt gebruik gemaakt van de typische gedragskenmerken van de verschillende vissoorten in de vangst. De doelsoort tong heeft de eigenschap zich diep(er) in te graven bij naderend gevaar (vistuig), waardoor er om deze vis effectief te vangen gebruik wordt gemaakt van wekkerkettingen of elektriciteit. De overige soorten graven zich niet of minder diep in en vertonen vluchtgedrag bij naderend gevaar. Juist deze eigenschappen worden gebruikt om met het schanspaneel effectief de bijvangst van ondermaatse vis te voorkomen. 
De overige vissoorten (anders dan de doelsoort tong) worden vóór het elektrische werkveld van het pulstuig gescheiden van de tongvangst middels een lichte extra onderpees. In tegenstelling tot de tong kan deze extra onderpees ervoor zorgen dat rondvis, schol en schar opschrikken en boven de pees langs proberen te vluchten. Aan de extra onderpees is een oplopend horizontaal scheidingspaneel bevestigd welke de vis omhoog leidt richting de bovenzijde van het net. Hier wordt een ontsnappingsmogelijkheid voor ondermaatse vis gecreëerd (Figuur 17). Marktwaardige vis kan de ontsnappingsmogelijkheid fysiek niet passeren en wordt boven het scheidingspaneel langs alsnog naar de kuil geleidt. In het geval dat het paneel er in slaagt om effectief rondvis naar boven te leiden kan mogelijk voorkomen worden dat kabeljauw en wijting puls gerelateerde beschadigingen aan de ruggengraat oplopen.

Tong zal waarschijnlijk minimaal reageren op de naderende lichte onderpees en in ingegraven positie onder het paneel door gaan richting het wekveld, hier wordt deze gestimuleerd om de bodem te verlaten en over de normale onderpees in het net te belanden. Om te voorkomen dat de tongen bij het verlaten van de bodem door het scheidingpaneel zwemmen richting de ontsnappingsmogelijkheid, is de maaswijdte van het scheidingspaneel dusdanig klein dat er geen marktwaardige tong door heen kan.

\section{Ontsnappingspaneel}

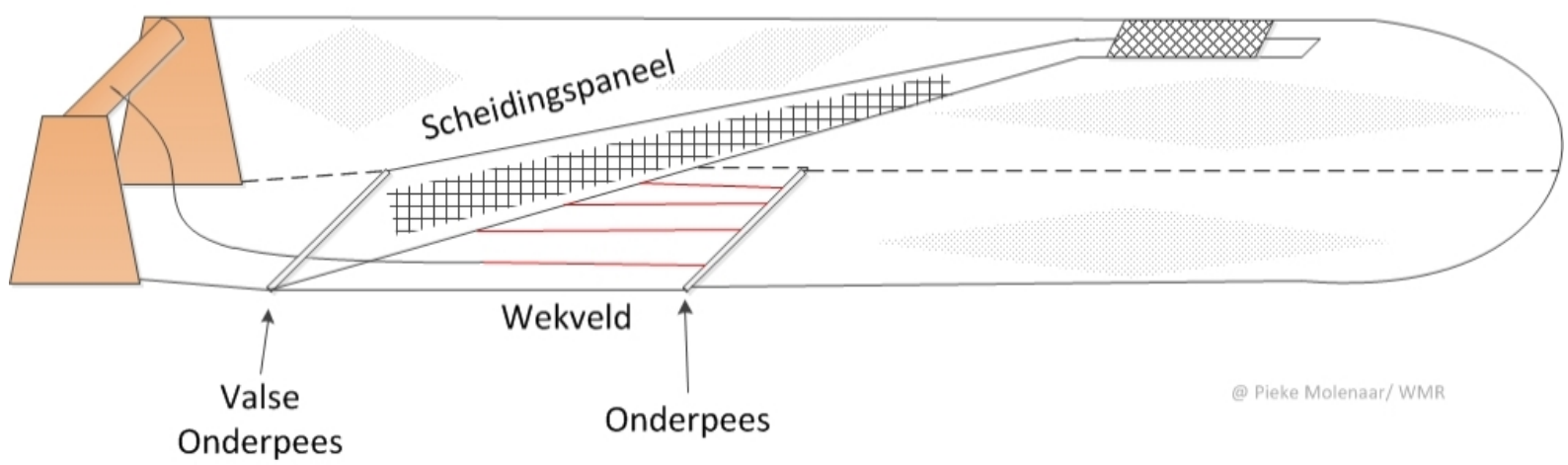

Figuur 17. Schematische weergave het schanspaneel met valse onderpees en ontsnappingspaneel in de bovenzijde van het net.

Als de werking van het ontsnappingspaneel beperkt is kan er ook voor gekozen worden om de gescheiden vangst op te vangen in een aparte kuil (Figuur 18). Als er geen tong boven het paneel langs gaat en in de bovenkuil terecht komt kan deze gemaakt worden van een grotere maaswijdte (120mm) waarmee een aanzienlijk deel van de ondermaatse vis kan ontsnappen. Om de effectiviteit van het scheidingspaneel te onderzoeken is het in eerste instantie aan te raden om gedurende het onderzoek zowel voor de bovenkuil als de onderkuil een maaswijdte van $80 \mathrm{~mm}$ aan te houden.

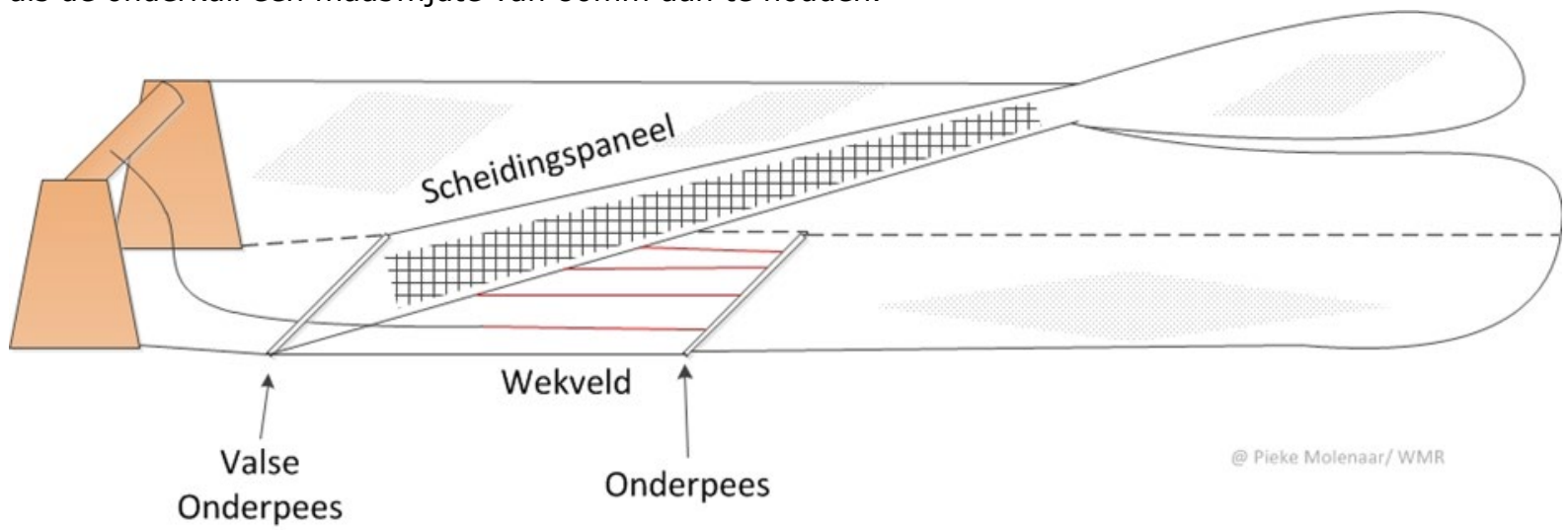

Figuur 18. Schematische weergave van het schanspaneel waarbij de gescheiden vangst opgevangen wordt in een tweede extra kuil.

Het idee en eerste ontwerp is ontstaan bij de coöperatie Westvoorn in Stellendam, er is daar destijds een test gedaan met een kotter die in de zuidelijke Noordzee op stenige bestekken vist. Echter liep het paneel dusdanig veel beschadigingen op in de eerste visweek dat er destijds is besloten om eventuele testen geen 
vervolg te geven. Binnen het project Netinnovatie Kottervisserij II zag de schipper van de WR244 mogelijkheden om dit idee opnieuw te testen, ditmaal op een eurokotter met een pulskor met een boom van 4.5 meter breed. Op het moment dat het paneel klaar was werd te kotter verkocht en kreeg het initiatief geen vervolg. In 2018 is het idee opgepakt door de TX94 en werd het idee verder uitgewerkt. Hierbij is deze aangepast aan de pulswing tuigen van deze kotter met als voornaamste doel om te kijken of de bijvangst van wijting verminderd kan worden.

\subsubsection{Schanspaneel zonder pees}

Het schanspaneel op de TX94 is gemaakt van netwerk met een maaswijdte van 60mm. Aan de voorzijde is het paneel $50 \mathrm{~cm}$ vóór de eerste conductor van de puls module vastgemaakt aan de trekontlasters van de onderpees (Figuur 19). Vanaf daar loopt het paneel schuim omhoog naar achteren tot 1.5 meter achter de onderpees. Met deze configuratie zijn in week 48 en 49 van 2018 testen uitgevoerd door de TX94.

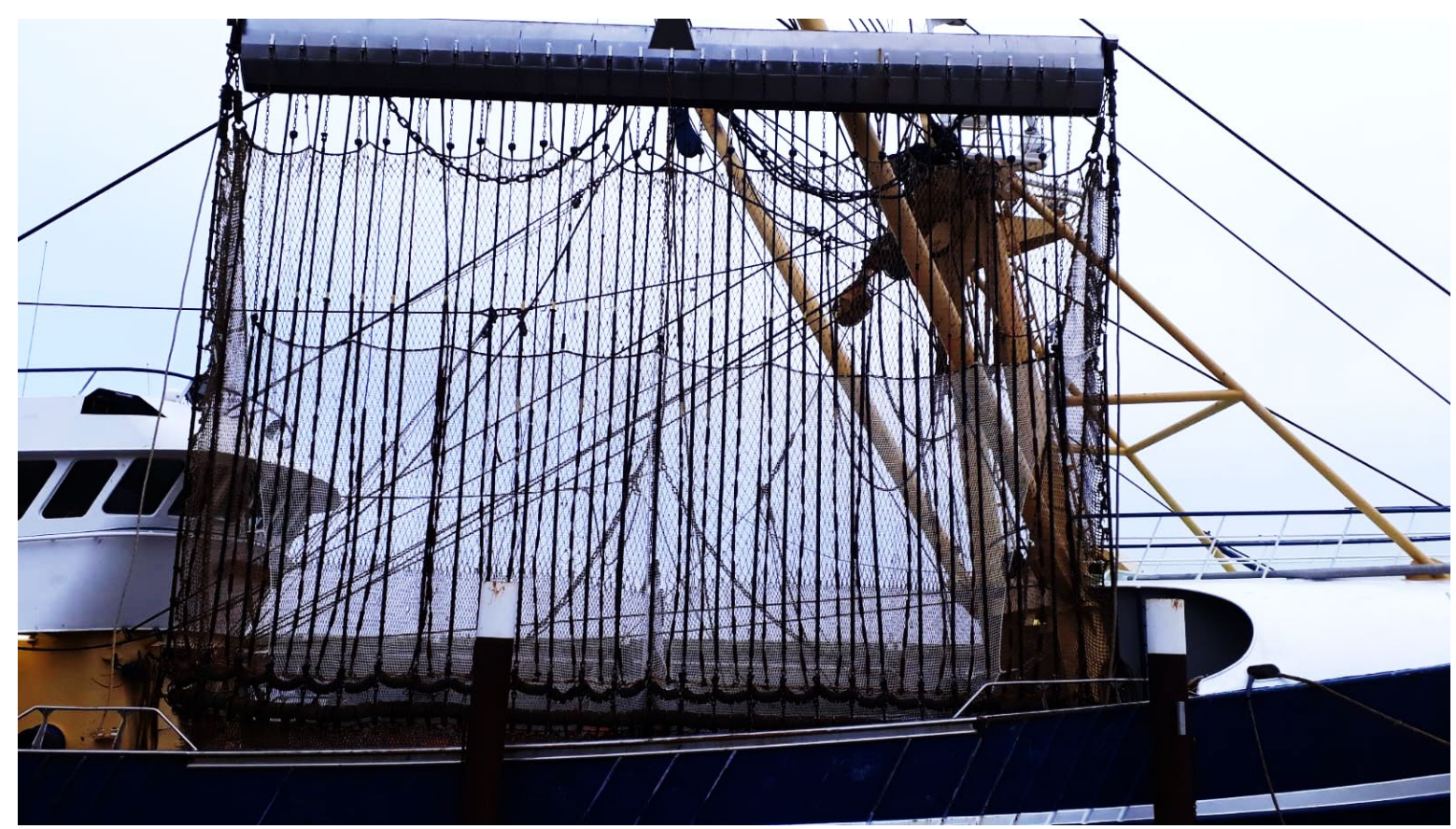

Figuur 19 Schanspaneel in het pulsnet van de TX94. Het paneel begint net voor de geleiders van de pulsmodules en loopt schuim omhoog tot 1.5 meter voorbij de onderpees.

\subsubsection{Schanspaneel met extra onderpees}

Het schanspaneel is na de eerste praktijktesten voorzien van een lichte onderpees die tussen de trekontlasters bevestigd is, de gele ketting en rubberschijven zijn zichtbaar in Figuur 20. Het doel was om de vis (anders dan tong) voor het paneel op te schrikken waardoor ze boven het paneel langs gaan. 


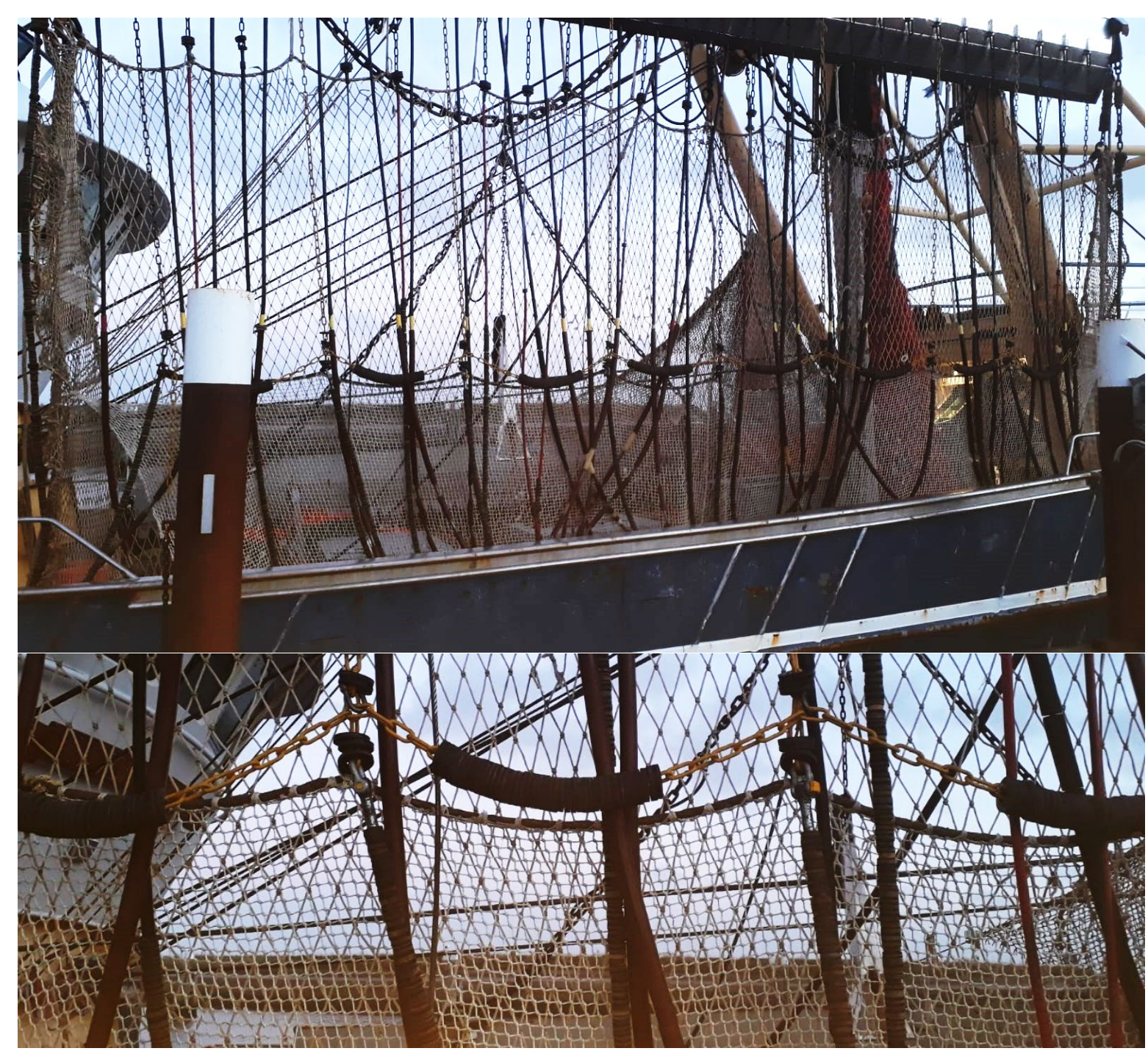

Figuur 20. Schanspaneel met voor het paneel een lichte valse onderpees welke bevestigd is aan de trekontlasters van het net.

\subsubsection{Resultaten self-sampling schanspaneel}

In week 49 van 2018 zijn de vangsten bemonsterd op basis van een versimpeld self-samplingsprotocol. Gedurende de visweek zijn 4 trekken bemonsterd, waarbij alle vangst van maatse tong, schol en maatse en ondermaatse wijting uit de vangst opgezocht en geregistreerd werd. Uit deze gegevens blijkt dat er een gelijke hoeveelheid of minder maatse tong gevangen wordt met het paneel. De vangsten van ondermaatse wijting zijn met $60-133 \%$ toegenomen in het net met het schanspaneel (Tabel 8 ).

Tabel 8. Resultaten in kilogram per trek voor week 49. Van 4 trekken zijn alle tong (maats), schol (maats) en wijting (maats \& ondermaats) per net (stuurboord en bakboord) verzameld en gewogen In de laatste kolom is per soort het procentuele verschil tussen beide netten aangeven. * betreft aantal vissen i.p.v. kilogram

\begin{tabular}{|c|c|c|c|c|c|c|c|c|c|c|c|c|c|c|c|}
\hline \multirow{3}{*}{ Trek } & \multicolumn{5}{|c|}{ Paneel (SB) } & \multicolumn{5}{|c|}{ Conventioneel (BB) } & \multicolumn{5}{|c|}{ Verschil in \% } \\
\hline & \multirow{2}{*}{$\begin{array}{l}\text { Tong } \\
>24 \mathrm{~cm}\end{array}$} & \multicolumn{2}{|c|}{ Schol } & \multicolumn{2}{|c|}{ Wijting } & \multirow{2}{*}{$\begin{array}{l}\text { Tong } \\
>24 \mathrm{~cm}\end{array}$} & \multicolumn{2}{|c|}{ Schol } & \multicolumn{2}{|c|}{ Wijting } & \multirow{2}{*}{$\begin{array}{l}\text { Tong } \\
>24 \mathrm{~cm}\end{array}$} & \multicolumn{2}{|c|}{ Schol } & \multicolumn{2}{|c|}{ Wijting } \\
\hline & & $>27 \mathrm{~cm}$ & $<27 \mathrm{~cm}$ & $>26 \mathrm{~cm}$ & $<26 \mathrm{~cm}$ & & $>27 \mathrm{~cm}$ & $<27 \mathrm{~cm}$ & $>26 \mathrm{~cm}$ & $<26 \mathrm{~cm}$ & & $>27 \mathrm{~cm}$ & $<27 \mathrm{~cm}$ & $>26 \mathrm{~cm}$ & $<26 \mathrm{~cm}$ \\
\hline 5 & 15 & 12 & - & $1^{*}$ & $20^{*}$ & 15 & 12 & - & $5^{*}$ & $10^{*}$ & 0 & 0 & - & -80 & 100 \\
\hline 17 & 15 & 50 & - & 10 & 40 & 20 & 50 & - & 10 & 25 & -25 & 0 & - & 0 & 60 \\
\hline 19 & 15 & 44 & - & 6 & 42 & 20 & 45 & - & 6 & 18 & -25 & -2 & - & 0 & 133 \\
\hline 25 & 10 & 31 & - & 13 & 55 & 15 & 28 & - & 12 & 30 & -33 & 11 & - & 8 & 83 \\
\hline
\end{tabular}




\subsubsection{Resultaten self-sampling schanspaneel met extra onderpees}

In week 50 is met het schanspaneel met extra onderpees het zelfde protocol aangehouden waarbij ook ondermaatse schol is verzameld, daarnaast zijn er bij elke trek alle maatse tongen per net apart gehouden en geregistreerd. Na 15 trekken met het paneel en extra pees zijn beide uit het net verwijderd. Om te controleren of beide netten gelijk op vissen is de vangst van maatse tong nog 13 trekken bijgehouden. Daarnaast is de vangst van wijting en schol nog twee trekken bemonsterd. Uit de resultaten bleek dat het net met paneel en extra pees significant minder tong (14.7\%) ving ten opzichte van het conventionele net (Tabel 9). Uit de resultaten van schol en wijting blijkt dat er geen verschil is tussen de maatse vangsten, maar dat de ondermaatse vangsten van wijting in de twee bemonsterde trekken met $247 \%$ en $283 \%$ toe namen (Tabel 10). Ook voor kleine schol werd dit waargenomen, met een toename van 133 en $150 \%$.

Tabel 9. Vangst marktwaardige tong in kilogram per trek (+-SD) van het stuurboordtuig en bakboordtuig. De eerste 15 trekken is er met het schanspaneel met extra onderpees gevist, vervolgens zijn er nog 13 trekken gevist zonder het paneel.

\begin{tabular}{cccc} 
Net & $\begin{array}{c}\text { Aantal } \\
\text { trekken }\end{array}$ & Gemiddelde tongvangst (kg/trek) & Verschil (\%) \\
\hline Paneel met extra pees (SB) & 15 & $14.7+-5.2$ & $-14.7 \%$ \\
Conventioneel (BB) & 15 & $17.3+-6.2$ & 0.006 \\
Conventioneel (SB) zonder paneel & 13 & $18.7+-4.4$ & 0.613 \\
Conventioneel (BB) & 13 & $18.2+-4$ &
\end{tabular}

Tabel 10. Resultaten week 50 van 4 trekken waarbij alle tong (maats), schol (maats \& ondermaats) en wijting (maats \& ondermaats) per net (stuurboord en bakboord) verzameld en gewogen zijn. Trek 14 en 15 zijn trekken met het schanspaneel en trek 17 en 22 zijn referentie treken zonder het schanspaneel. In de laatste kolom is per soort het procentuele verschil tussen beide netten aangeven.

\begin{tabular}{|c|c|c|c|c|c|c|c|c|c|c|c|c|c|c|c|}
\hline \multirow{3}{*}{ Trek } & \multicolumn{5}{|c|}{ Paneel met extra onderpees(SB) } & \multicolumn{5}{|c|}{ Conventioneel (BB) } & \multicolumn{5}{|c|}{ Verschil in \% } \\
\hline & \multirow{2}{*}{$\begin{array}{l}\text { Tong } \\
>24 \mathrm{~cm}\end{array}$} & \multicolumn{2}{|c|}{ Schol } & \multicolumn{2}{|c|}{ Wijting } & \multirow{2}{*}{$\begin{array}{l}\text { Tong } \\
>24 \mathrm{~cm}\end{array}$} & \multicolumn{2}{|c|}{ Schol } & \multicolumn{2}{|c|}{ Wijting } & \multirow{2}{*}{$\begin{array}{l}\text { Tong } \\
>24 \mathrm{~cm}\end{array}$} & \multicolumn{2}{|c|}{ Schol } & \multicolumn{2}{|c|}{ Wijting } \\
\hline & & $>27 \mathrm{~cm}$ & $<27 \mathrm{~cm}$ & $>26 \mathrm{~cm}$ & $<26 \mathrm{~cm}$ & & $>27 \mathrm{~cm}$ & $<27 \mathrm{~cm}$ & $>26 \mathrm{~cm}$ & $<26 \mathrm{~cm}$ & & $>27 \mathrm{~cm}$ & $<27 \mathrm{~cm}$ & $>26 \mathrm{~cm}$ & $<26 \mathrm{~cm}$ \\
\hline 14 & 9 & 45 & 35 & 9 & 52 & 11 & 45 & 15 & 9 & 15 & -18 & 0 & 133 & 0 & 247 \\
\hline \multirow[t]{2}{*}{15} & 14 & 37 & 30 & 7 & 46 & 16 & 37 & 12 & 7 & 12 & -13 & 0 & 150 & 0 & 283 \\
\hline & \multicolumn{5}{|c|}{ Conventioneel (SB) zonder paneel } & \multicolumn{5}{|c|}{ Conventioneel (BB) } & & & & & \\
\hline 17 & 15 & 39 & 22 & 11 & 18 & 20 & 38 & 21 & 11 & 19 & -25 & 3 & 5 & 0 & -5 \\
\hline 22 & 25 & 30 & 11 & 17 & 18 & 20 & 30 & 11 & 17 & 18 & 25 & 0 & 0 & 0 & 0 \\
\hline
\end{tabular}

\subsubsection{Conclusie}

Tegen de verwachting in werd er door het schanspaneel met en zonder lichte extra onderpees aanzienlijk meer wijting gevangen in het net ten opzichte van het bakboord tuig. Het paneel is aan de trekontlasters bevestigd welke er waarschijnlijk voor zorgen dat het paneel 10-15 cm van de bodem begint. Deze ruimte gebruikt wijting blijkbaar om onder het paneel door te gaan, waarna ze door de toegepaste $60 \mathrm{~mm}$ mazen niet meer omhoog kunnen zwemmen en daardoor ook niet door de grote mazen in de eerste sectie van de bovenzijde van het net kunnen ontsnappen. Mogelijk zwemt wijting bij het naderen van de wing eerst naar de zeebodem, om met het naderen of passeren van de onderpees een uitgang in de bozenzijde van het net te zoeken (Molenaar et al, 2018). Met het toepassen een lichte extra onderpees ving het net met schanspaneel gemiddeld per trek (14.7\%) significant minder tong ten opzichte van het bakboord tuig. In het geval het schanspaneel nogmaals getest wordt is het aan te bevelen om de licht onderpees over de bodem te laten lopen en het paneel hier direct aan te bevestigen. Dit voorkomt dat er ruimte ontstaat tussen de pees en begin van het paneel waardoor de wijting er alsnog onderdoor gaat. Het tongverlies door het toepassen van een lichte extra onderpees vóór het pulsveld kan voor een visser onacceptabel zijn waardoor verdere toepassing van het paneel beperkt is. 


\subsection{Kiwikuil}

\subsubsection{Inleiding en beschrijving}

De kiwikuil betreft een Nederlandse variatie op een innovatief concept uit Nieuw-Zeeland (Precision sea food harvesting) waarbij een kuil van een gesleept vistuig vervangen wordt door een lange cilindervormige 'zak'. In deze cilinder zijn openingen gemaakt waardoor ondermaatse of ongewenste bijvangsten kunnen ontsnappen. Deze gaten kunnen aan de hand van de vorm van de vis geoptimaliseerd worden. De laatste sectie van deze cilinder bevat geen gaten en is een dichte 'zak', hier kan de gevangen vis in een relatief rustige omgeving verblijven tot het net boven gehaald wordt. Door het reduceren van de waterstroom en werveling in de innovatieve kuil komt de vis beperkt vermoeid en onbeschadigd aan boord. Echter is het Nieuw-Zeelandse ontwerp niet direct geschikt voor de Nederlandse visserij, en dient hierop aangepast te worden.

De kiwikuil is een innovatie waarbij de kuil in de tongvisserij met pulswing tuigen vervangen wordt door een kuil uit vezel versterkt zeildoek. Een kuil van conventioneel netwerk heeft tijdens het vissen een wervelende waterstroming waardoor vissen en benthische organismen veelvuldig met elkaar en het netwerk in contact komen, hierdoor kunnen de vissen beschadigingen oplopen wat een negatief effect kan hebben op de viskwaliteit. Om deze beschadigingen te voorkomen is er een kuil gemaakt van zeildoek met openingen die zijn geoptimaliseerd en georiënteerd voor het ontsnappen van ondermaatse tong en kleine schol. De gedachte is dat door de gefixeerde vorm van kiwikuil de vorm van de kuil en openingen tijdens het vissen behouden blijft. De waterdruk en stroming in de kuil wordt door de openingen steeds minder, en achter in de kuil zal de stroming minimaal zijn. Hierdoor hebben de ondermaatse vissen meer kans om rond te zwemmen en te zoeken naar een uitgang.

Naast de selectievere eigenschappen zou hiermee de overlevingskans van de vis die wordt teruggezet in zee (discards) verbeterd kunnen worden. In het reguliere net krijgt de vis gedurende het verblijf in de kuil een continue stroom van schurend zandhoudend water over zich heen. Doordat het einde van de kiwikuil gesloten is zal het water hier met de kuil mee bewegen zodat een meer visvriendelijke omgeving ontstaat en de conditie van de vis waarschijnlijk verbeterd ten opzichte van een conventionele kuil. De overlevingskans van discards neemt toe als de conditie waarin de vis aan dek komt verbetert (Schram en Molenaar, 2018). Op 26 juni 2018 is een schaalmodel (Figuur 21) getest in het Innovatie Centrum zuid west Nederland te Stellendam om te beoordelen hoe het prototype achter het net "staat". Tijdens vier testen bleek dat de kuil van zeildoek de waterstroom in het net niet negatief beïnvloed.

Gezien de positieve testen met schaalmodellen is besloten om de kiwikuil in de praktijk op een pulskotter (GO23) te testen. Hiervoor is er door Van Wijk en Coöperatie Westvoorn een prototype kiwikuil gemaakt voor één tuig van de G023. Tijdens de twee praktijkproeven op de GO23 is er gekeken hoe er aan boord met de kiwikuil gewerkt kan worden en naar het bezinken van sediment in het laatste stuk van de kuil. Daarnaast is de selectiviteit en visconditie van de gevangen vis bemonsterd met een selfsamplingsprotocol.

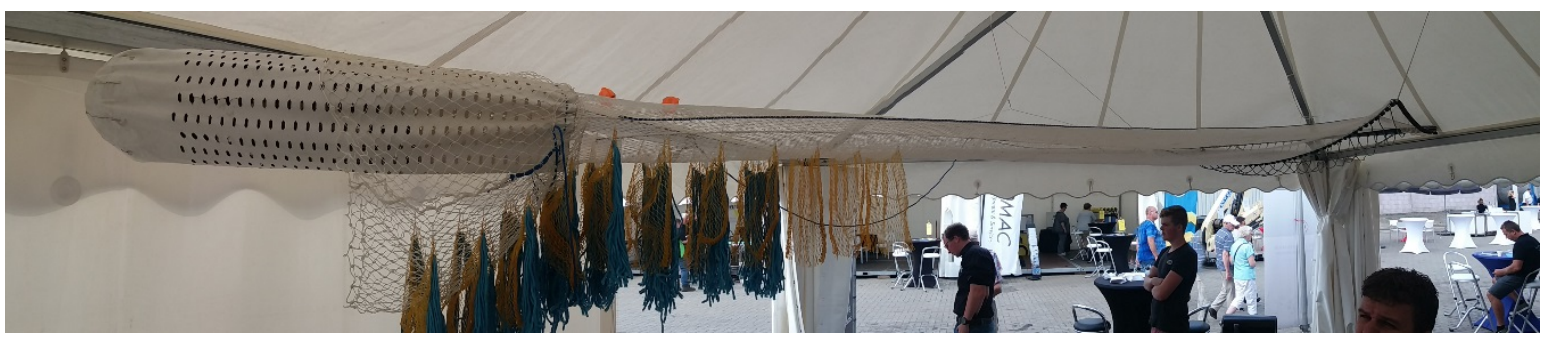

Figuur 21. Schaalmodel van een pulsnet met daaraan een prototype kiwikuil

\subsubsection{Proefopzet}

De praktijkproeven met een prototype van de kiwikuil hadden drie doelen; het opdoen van praktische ervaring met het vissen met de kiwikuil, het onderzoeken van de vangstefficiëntie en het meten van de 
visconditie middels het scoren van beschadigingen. Hiervoor zijn aan boord van de pulskotter GO-23 aan de 1 zijde een reguliere kuil en aan de andere zijde de kiwikuil bevestigd, beide tuigen van de GO23 zijn 12 meter breed. Voor het meten van de effecten zijn twee protocollen opgesteld; één voor het meten van vangstsamenstelling (Figuur 21) en één apart protocol voor het meten van de visconditie. Het uitvoeren van beide protocollen in één trek is arbeidsintensief en daarom slechts een beperkt aantal trekken gedaan.

\subsubsection{Monitoren visconditie}

De overlevingskansen van teruggezette ongewenste bijvangsten zijn gerelateerd aan de beschadigen die de vis heeft opgelopen tijdens het vangst en verwerkingsproces (Schram \& Molenaar 2018; Van der Reijden et al. 2017). Het systematisch beoordelen van de conditie van vissen uit de conventionele en kiwikuil geeft een inzicht in de relatieve overlevingskansen van schol uit beide kuilen. Deze methode is ook gebruikt in onderzoek naar het verbeteren van overlevingskansen van ongewenste bijvangsten (Schram \& Molenaar 2018) en een vergelijkbaar self-samplingsprotocol is gebruikt om de effecten van de kiwikuil te beoordelen.

Bij de bemonstering van de trek werden uit beide kuilen tijdens de verwerking van de vangst willekeurig 30 ondermaatse schollen van het einde van de verwerkingsband gepakt en in een met zeewater gevulde tub geplaatst. Beide tubs waren voorzien van doorstroming met zeewater. De vangst van bakboord en stuurboord werd per trek om en om als eerste of als tweede verwerkt om de blootstellingsduur van de vangst aan lucht de balanceren. Na het verzamelen van de vissen, zijn de vissen die als eerste zijn verzameld ook als eerste beoordeeld. Voor elke individuele vis werd de aanwezigheid van beschadigen gescoord, een klasse toegekend en de totale lengte gemeten. De vitaliteitsklassen en beschadigingsscores zijn weergegeven in Tabel 11.

Tabel 11. Definities gebruikt voor registreren vitaliteit en beschadigingen van ondermaatse schol.

\begin{tabular}{|c|c|}
\hline \multicolumn{2}{|c|}{ Vitaliteitsklasse (naar: van Marlen et al. 2016) } \\
\hline Klasse & Omschrijving \\
\hline A & Levendige vis, geen zichtbare beschadigingen of verlies van schubben of slijmlaag. \\
\hline B & $\begin{array}{l}\text { Minder levendige vis, tot } 20 \% \text { verlies van schubben en/of slijmlaag, kleine krassen } \\
\text { en puntbloedingen op de onderzijde van de vis. }\end{array}$ \\
\hline C & $\begin{array}{l}\text { Slome vis, meerdere krassen, tot } 50 \% \text { van schubben en/of slijmlaag. Meerdere } \\
\text { rode vlekken of onderhuidse- en puntbloedingen op onderzijde vis. }\end{array}$ \\
\hline D & $\begin{array}{l}\text { Slome vis, rode vlekken of bloedingen op kop, veel krassen en kale plekken, meer } \\
\text { dan } 50 \% \text { verlies van schubben en/of slijmlaag. Veel puntbloedingen en } \\
\text { onderhuidse bloedingen op onderzijde vis. Dode vissen worden ook aan klasse D } \\
\text { toegewezen. }\end{array}$ \\
\hline Dood & $\begin{array}{l}\text { Vis vertoont in water geen ventilerende beweging met kieuwen voor een periode } \\
\text { van minimaal } 20 \text { seconden. }\end{array}$ \\
\hline \multicolumn{2}{|c|}{ Beschadigingsscores } \\
\hline Beschadiging & Omschrijving ( 1 =aanwezig; $0=$ afwezig) \\
\hline Vin & In de lucht gehouden, de vis heeft beschadigingen op de (staart)vinnen. \\
\hline $\begin{array}{l}\text { Schubverlies } \\
>50 \%\end{array}$ & Huidbeschadigingen of schub/slijmverlies van meer dan $50 \%$ van het oppervlakte. \\
\hline Kop bloeding & Aanwezigheid van bloedingen aan de kop. \\
\hline $\begin{array}{l}\text { Onderhuidse- } \\
\text { bloeding }\end{array}$ & Aanwezigheid van onderhuidse bloedingen anders dan puntbloedingen. \\
\hline Ingewanden & Ingewanden zijn zichtbaar buiten het lichaam van de vis. \\
\hline Wond & Aanwezigheid van een wond, zodanig dat de huid daadwerkelijk kapot is. \\
\hline
\end{tabular}

\subsubsection{Resultaten self-sampling kiwikuil}

Het eerste prototype op commerciële schaal van de kiwikuil is op 15 oktober 2018 getest op de GO23 (Figuur 22). De openingen in het 5.7 meter langer prototype hadden een diameter van 70mm (bijlage 5), 
dit kan mogelijk uitrekken tijdens het vissen door de elastische eigenschappen van het zeildoek. De kiwikuil was bevestigd aan de het bakboord pulswing tuig en werd vergeleken met het conventionele stuurboord tuig. Er zijn vier trekken van 120 minuten gedaan op een diepte van 33 tot 45 meter met een snelheid van 4.8 knopen. De vangstsamenstelling is in 3 trekken bemonsterd en de visconditie is in twee trekken gescoord.
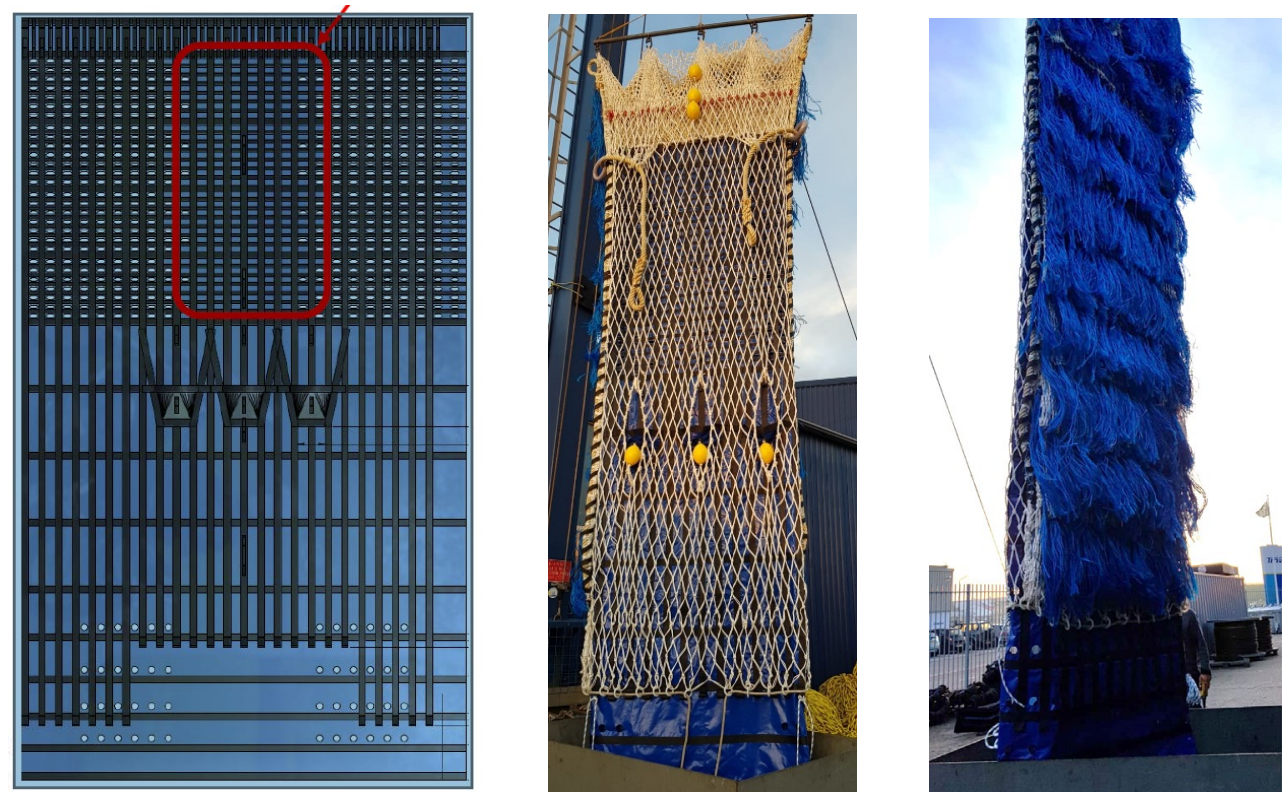

Figuur 22. Eerste commerciële prototype van de kiwikuil. Links, de platte concepttekening met daarin de openingen weergegeven, de rode cirkel zijn de voor de $3^{e}$ en $4^{e}$ trek met dit ontwerp extra gaten aangebracht. Midden, de bovenzijde van het prototype, om de kiwikuil te beschermen is er een overkuil om het prototype gemaakt. De onderzijde van de kiwikuil wordt voor het uitzetten van de netten opgerold. Rechts, de onderzijde van de kiwi- en beschermkuil, deze zijde is voorzien van pluis om te voorkomen dat de steenachtige visgronden van de GO23 de kiwikuil beschadigen.

Bij het aan boord brengen van de eerste vangst van de kiwikuil ontstond er een scheur in het zeildoek waardoor er mogelijk vangst verloren is gegaan. Ter verbetering van de waterdoorstroom door de kiwikuil zijn er voor de $3^{\text {e }}$ trek 140 extra openingen in het zeildoek gemaakt, boven op de 476 in de originele kiwikuil. Voor de $4^{\mathrm{e}}$ trek zijn daar nog 40 gaten aan toegevoegd. Door de lagere (tong)vangsten is de kiwikuil na 4 trekken vervangen door een conventionele kuil. Door inconsistenties in de vangstbemonstering zijn alleen de totale vangst en marktwaardige tong en schol weergegeven. De resultaten van de bemonsterde trekken zijn weergegeven in Tabel 12 en Figuur 23. Het reisverslag met de bevindingen en opmerkingen zijn bijgevoegd in bijlage 5 .

De resultaten van de vangstbemonstering (Tabel 12) laten zien dat ten opzichte van de conventionele kuil de kiwikuil gemiddeld 63\% minder ving (totale vangst), over 3 trekken werd er gemiddeld $152 \mathrm{~kg}$ met de kiwikuil en $408 \mathrm{~kg}$ in de conventionele kuil gevangen. De kiwikuil ving $70 \%$ minder tong en $37 \%$ minder schol.

Tabel 12. Gewichten in kilogram per trek van alle vangst van maatse soorten zoals schol en tong per kuil van de conventionele en kiwikuil.

\begin{tabular}{l|ccc|ccc} 
& \multicolumn{3}{c|}{ Kiwikuil (bb) } & \multicolumn{3}{c}{ Conventionele kuil (sb) } \\
Trek & Vangst kuil & Schol & Tong & Vangst kuil & Schol & Tong \\
\hline 1 & 140 & 8 & 4 & 280 & 18 & 18 \\
2 & 175 & 30 & 18 & 420 & 61 & 42 \\
4 & 140 & 31 & 14 & 525 & 41 & 50 \\
Gemiddeld & $\mathbf{1 5 2}$ & $\mathbf{2 3}$ & $\mathbf{1 2}$ & $\mathbf{4 0 8}$ & $\mathbf{4 0}$ & $\mathbf{3 7}$
\end{tabular}

Voor elke kuil is de conditie beoordeelt van 60 ondermaatse schollen, in de kiwikuil was de gemiddelde lengte $23.2 \mathrm{~cm}$ waar dit voor de conventionele kuil $23.0 \mathrm{~cm}$ was. Uit de monitoring van de visconditie (Figuur 23) bleek dat $63 \%$ van de bemonsterde vissen uit de conventionele kuil meer dan $50 \%$ van de schubben of slijmlaag verloren was, voor de kiwikuil was dit 50\%. Kop bloedingen waren aanwezig bij $63 \%$ van de vissen uit de conventionele kuil en in tegenstellig was dit bij 53\% van de vissen uit de kiwikuil het geval. Bij 
de overige beschadigingen werden geen grote verschillen waargenomen. De vitaliteitsscore laat een ten opzichte van de conventionele kuil een verschuiving van de D-score naar de B-score zien. In de kiwikuil scoorde $35 \%$ van de bemonsterde vissen een $\mathrm{D}$, tegenover $42 \%$ in de conventionele kuil. Voor de B-score was dit $28 \%$ voor de kiwikuil en $20 \%$ voor de conventionele kuil. Het aantal vissen dat dood werd aangetroffen op het moment van beoordelen was $10 \%$ in de kiwikuil en $5 \%$ in de conventionele kuil.

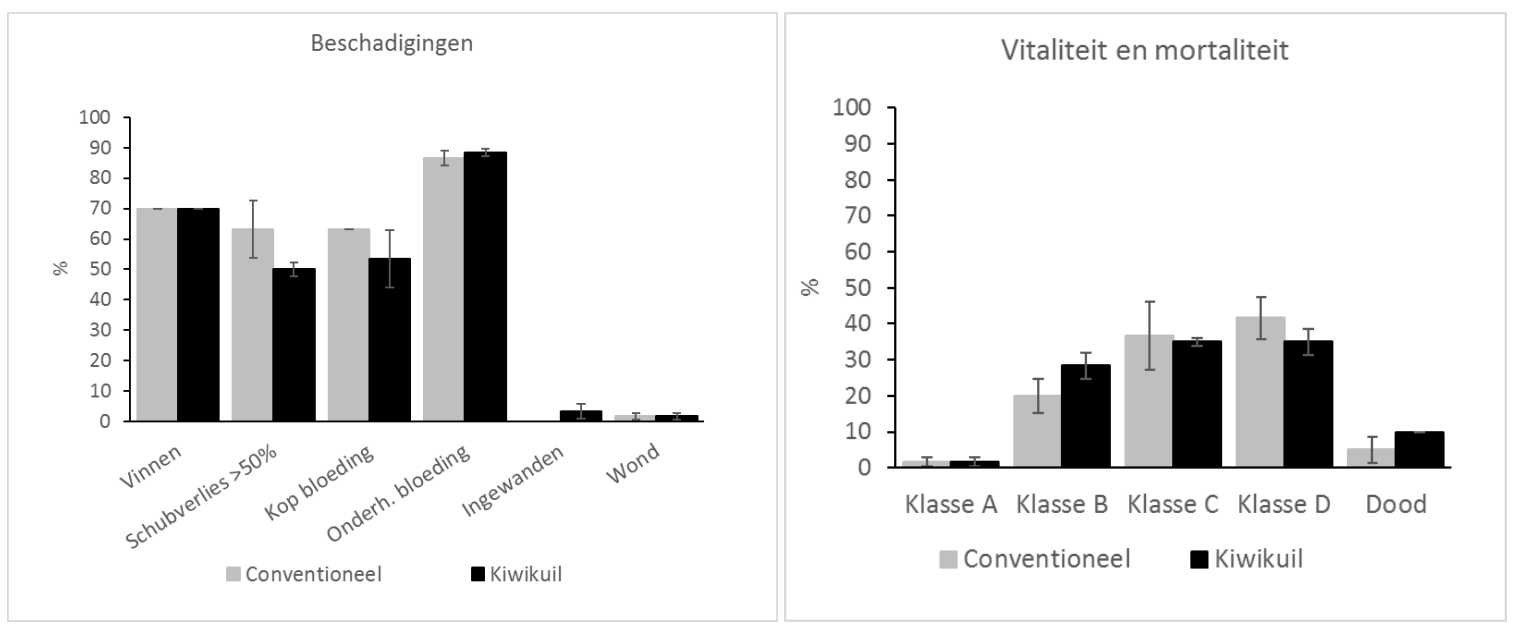

Figuur 23. Links percentage beschadigen waargenomen bij ondermaatse schol in de kiwikuil en de conventionele kuil. Rechts de vitaliteitsklasse (A t/m D) van ondermaatse schol in de kiwikuil en conventionele kuil waarbij A levendige onbeschadigde vissen zijn en $D$ beschadigde vissen met geringe overlevingskans. Daarnaast is het percentage vissen dat dood was tijdens het monitoren weergeven.

De extra trekkracht van het tuig met de kiwikuil was gedurende de trek ongeveer $200 \mathrm{~kg}$. Na de eerste experimenten aan boord van de GO23 hebben de bemanning en ontwikkelaars geconcludeerd dat de doorstroming van het ontwerp verbeterd moet worden. In het achternet (100 mm mazen) waaraan de kiwikuil bevestigd zat werden veel vissen waargenomen die gestoken zaten in de mazen. Dit duidt op een beperkte doorstroming in de kiwikuil waardoor een deel van de vangst door de $100 \mathrm{~mm}$ mazen kan ontsnappen. Het aantal door de mazen gestoken vissen werd minder bij het aanbrengen van extra openingen (trek 3 en 4). Ook werd opgemerkt dat de $70 \mathrm{~mm}$ openingen te wijd waren, er zaten te veel marktwaardige vissen klem in de openingen en daarnaast is er mogelijk een deel ontsnapt. Ook werd er elke trek meer zand in de vangst van de kiwikuil waargenomen.

\subsubsection{Verlengde kiwikuil}

Uit de test met het eerste prototype kwamen een aantal verbeterpunten naar voren waarmee een verbeterde versie is gemaakt. Om het vangstverlies te beperken is de diameter van de gaten (bijlage 5) verkleind naar $60 \mathrm{~mm}$ (kwam bij testen naar voren dat maatse tong gemakkelijk door $70 \mathrm{~mm}$ zeildoek kon). Daarnaast is het ontwerp langer gemaakt (6.4 meter) en zijn er meer gaten aangebracht om de waterstroom door de kuil te verbeteren (Figuur 24). De gedachte is dat er dan minder vissen gestoken zitten in de mazen vóór de kuil en daarnaast zal er met een betere doorstroming misschien minder zand in de kuil achterblijven. 

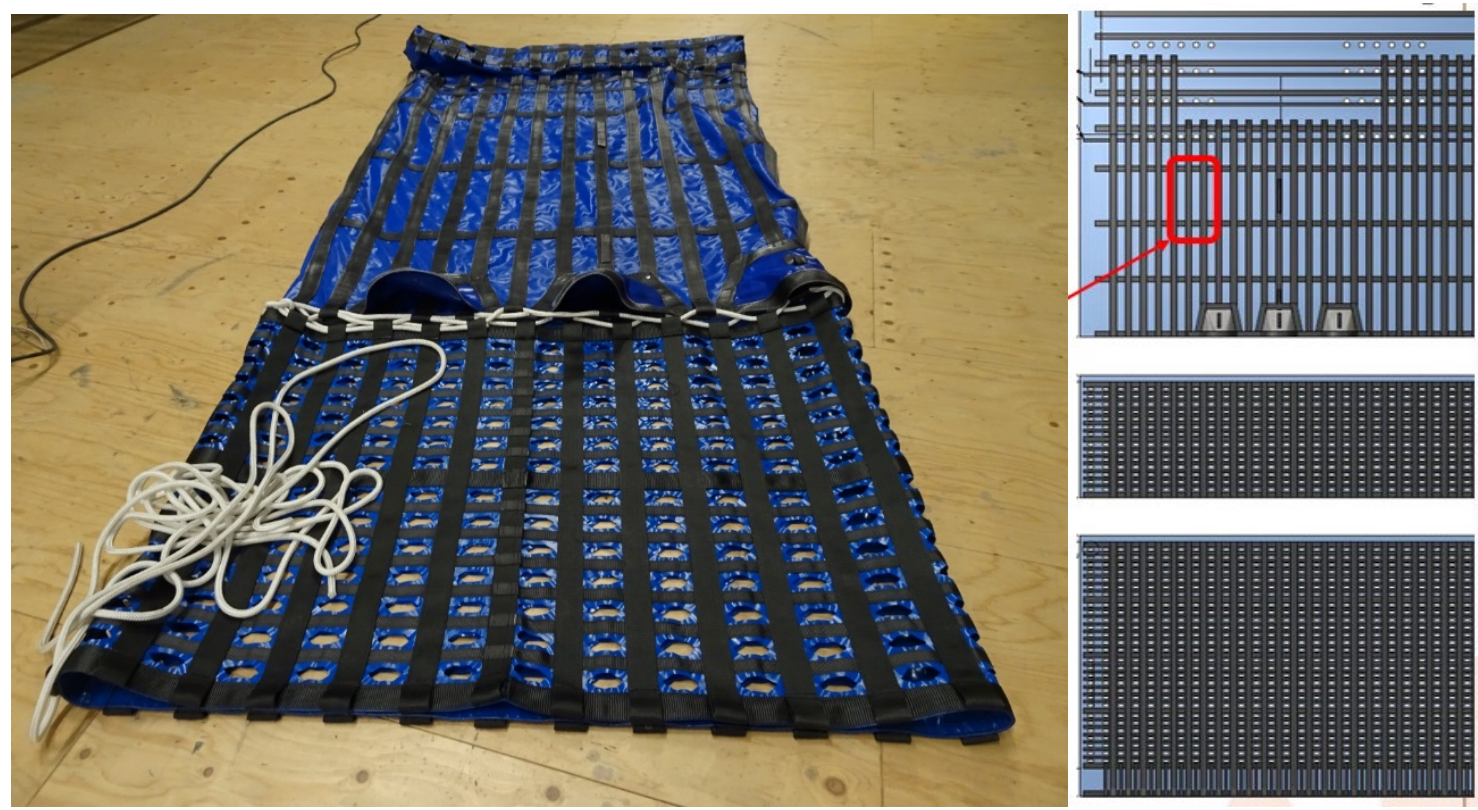

Figuur 24. Verlengde kiwikuil. Op de linker foto ziet men twee secties; de verlengde sectie met gaten en dichte sectie van de kiwikuil zichtbaar. Op de rechter foto ziet men een platte concepttekening de 3 secties van de verlengde kiwikuil, boven de dichte kuil en onder twee secties met gaten. De rode cirkel geef de locatie van de scheur aan, deze ontstond bij het aan boord halen van de kuil.

\subsubsection{Resultaten self-sampling verlengde kiwikuil}

In op 11 december 2018 is er op de GO23 drie trekken gevist met de verlengde kiwikuil. In deze drie trekken is 120 minuten gevist op een diepte van 35 tot 45 meter met een snelheid van 4.8 knopen. De kiwikuil was aan het bakboord pulsnet bevestigd en de effectiviteit is vergeleken met een conventionele stuurboordnet. De vangst van beide kuilen is apart verwerkt en geregistreerd, alleen de tong, schol en totale vangst is gerapporteerd door inconsistenties in de bemonstering. Daarnaast zijn er elke trek per kuil 30 ondermaatse schollen verzameld waarvan de conditie conform protocol beoordeeld is. De verlengde kiwikuil trok aan et begin van de trek $2 \%$ zwaarder ten opzichte van het conventionele tuig.

De resultaten van de vangstbemonstering (Tabel 13) laten zien dat ten opzichte van de conventionele kuil de verlengde kiwikuil gemiddeld 39\% minder ving, over 3 trekken werd er gemiddeld per trek $327 \mathrm{~kg}$ met de kiwikuil en $537 \mathrm{~kg}$ in de conventionele kuil gevangen. De kiwikuil ving 48\% minder tong en 24\% minder schol. In alle bemonsterde trekken werd naar de normale vangst ook zand in de kiwikuil waargenomen.

Tabel 13. Gewichten in kilogram per trek van alle vangst, maatse schol en tong per kuil. Gezien de verschillende maaswijdten tussen beide kuilen en het experimentele karakter van de proef dienen deze resultaten met voorzichtigheid gereinterpreteerd te worden.

\begin{tabular}{l|ccc|ccc} 
& \multicolumn{3}{|c|}{ Verlengde Kiwikuil (bb) } & \multicolumn{3}{c}{ Conventionele kuil (sb) } \\
Trek & Vangst kuil & Schol & Tong & Vangst kuil & Schol & Tong \\
\hline 1 & 350 & 37 & 20 & 525 & 60 & 38 \\
2 & 280 & 80 & 25 & 525 & 80 & 54 \\
3 & 350 & 48 & 13 & 560 & 77 & 20 \\
Gemiddeld & $\mathbf{3 2 7}$ & $\mathbf{5 5}$ & $\mathbf{1 9}$ & $\mathbf{5 3 7}$ & $\mathbf{7 2}$ & $\mathbf{3 7}$
\end{tabular}

Voor elke kuil is de conditie beoordeelt van 90 ondermaatse schollen, in de kiwikuil was de gemiddelde lengte $22.2 \mathrm{~cm}$ waar dit voor de conventionele kuil $21.6 \mathrm{~cm}$ was. Uit de monitoring van de visconditie (Figuur 25) bleek dat bemonsterde vissen op de score 'ingewanden' na op in de kiwikuil op alle vlakken minder beschadigingen scoorden. Beschadigde vinnen werden bij $73 \%$ van de vissen uit de conventionele kuil waargenomen, tegen $58 \%$ in de kiwikuil. Voor schubverlies was dit $80 \%$ tegen $61 \%$, kopbloedingen $76 \%$ tegen $60 \%$, onderhuidse bloedingen $67 \%$ tegen $50 \%$. Wonden werden niet waargenomen bij vissen uit de kiwikuil, tegen $3 \%$ in de conventionele kuil. 
De vitaliteitsscore laat een ten opzichte van de conventionele kuil een kleine verschuiving van de D-score naar een $C$ en $B$-score zien. In de kiwikuil scoorde $56 \%$ van de bemonsterde vissen een $D$, tegenover $60 \%$ in de conventionele kuil. Het aantal vissen dat dood werd aangetroffen op het moment van beoordelen was $17 \%$ in de kiwikuil en $12 \%$ in de conventionele kuil.

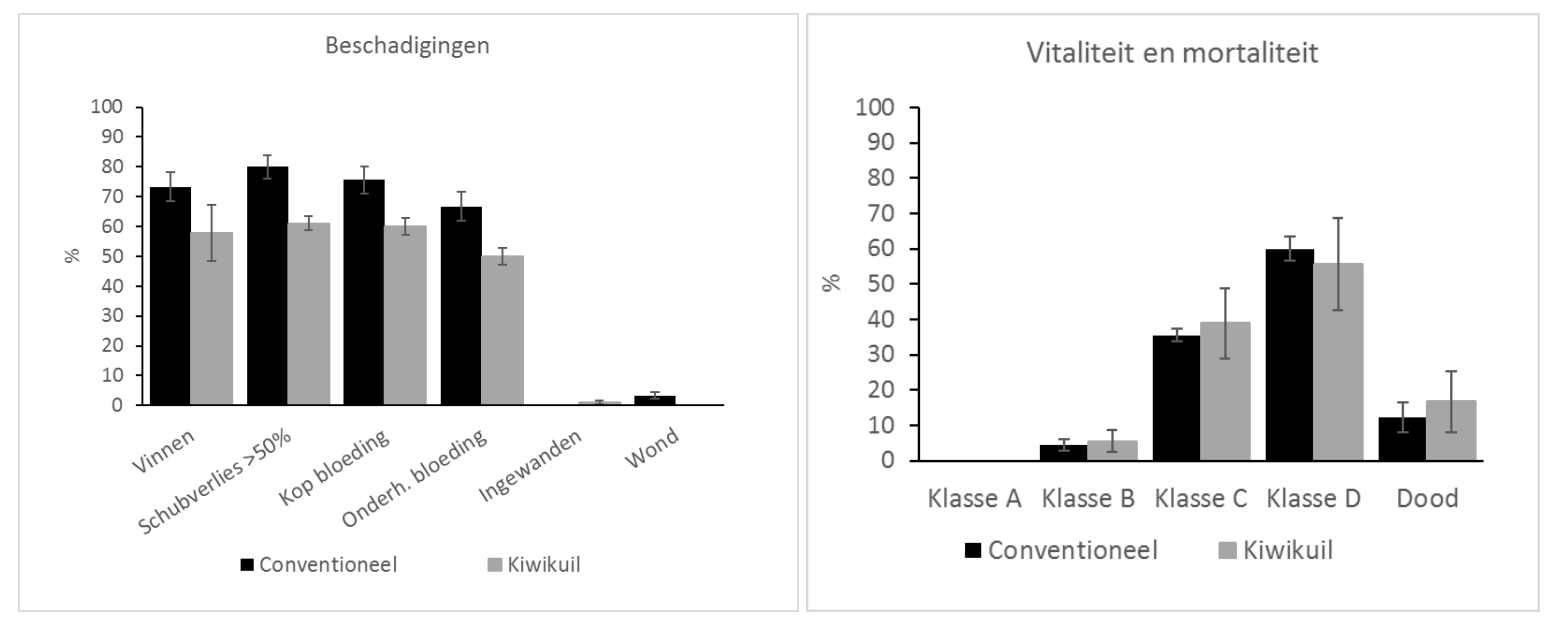

Figuur 25. Links, percentage beschadigen waargenomen bij ondermaatse schol in de verlengde kiwikuil en de conventionele kuil. Rechts, de vitaliteitsklasse (A $t / m$ D) van ondermaatse schol in de kiwikuil en conventionele kuil (waarbij A levendige onbeschadigde vissen zijn en $D$ beschadigde vissen met geringe overlevingskans). Daarnaast is het percentage vissen dat dood was tijdens het monitoren weergeven.

\subsubsection{Conclusie}

De vangsten van marktwaardige vis waren in de verlengde kiwikuil aanzienlijk minder dan de conventionele kuil. Gezien de maaswijdte van de openingen is het niet mogelijk dat marktwaardige schol uit de kuil ontsnapt, mogelijk is de waterstroom door de kuil te beperkt waardoor schol en tong door de grote mazen in de voorzijde van het net ontsnappen. Tong kan daarentegen mogelijk ook ontsnappen door de gaten in de kiwikuil, het dient daarom de aanbeveling om de opening te optimaliseren naar de breedte en dikte van de kleinste marktwaardige tong $(24 \mathrm{~cm})$.

Voor ondermaatse schol uit de verlengde kiwikuil worden minder beschadigingen waargenomen ten opzichte van de conventionele kuil. Hoewel er minder beschadigingen waargenomen worden is er nog steeds een aanzienlijk percentage van de vissen beschadigd, dit heeft mogelijk met de steenachtige visgronden van de GO23 te maken waarbij er ook stenen bijgevangen worden. Hierdoor is de verschuiving naar betere beschadigingsklassen (A/B) waarschijnlijk beperkt. Opvallend is het hogere percentage directe mortaliteit in de kiwikuil, mogelijk heeft dit een verband met het zand dat gevangen wordt in de kiwikuil. Hoewel de uitvoering en vangstefficiëntie van de kiwikuil nog verbeterd dient te worden hebben de resultaten op het gebied van beschadigingen wel potentie om de overleving van ongewenste bijvangsten te verhogen.

\subsection{Lucht puls}

Gezien het volledig verbieden van de pulstechniek is er binnen de Nederlandse visserijsector gekeken naar een eventueel alternatief voor elektrische (puls) of mechanische (wekker kettingen) stimulering om platvis te vangen. Een mogelijkheid werd gezien in het stimuleren van platvis door middel van perslucht. Het idee is om platvissen met luchtbellen te prikkelen zodat zij opzwemmen van- of uit de zeebodem en dan met een sleepnet gevangen kunnen worden. Voor de visserij met wekkerkettingen is de ontwikkeling van een alternatieve visserij die tot minder brandstofgebruik leidt gewenst. Om de werking en effectiviteit van dit idee te testen is een prototype ontwikkeld waarmee testen gedaan kunnen worden onder gecontroleerd omstandigheden. 
Vooraf was onbekend of platvissen die zich op of in de zeebodem bevinden met luchtbellen dusdanig geprikkeld kunnen worden dat zij loskomen van de bodem zodat zij vervolgens met een sleepnet gevangen kunnen worden. Ook was niet bekend welke verschillen in 'prikkelbaarheid met lucht' bestaan tussen vissoorten en tussen vissen van verschillende grootte binnen vissoorten en hoe deze verschillen zijn gerelateerd aan technische instelling van het vistuig op basis van luchtbellen. Kennis van dergelijke verschillen is echter van belang voor de ontwikkeling van een vistuig waarbij perslucht gebruikt wordt om de vissen te simuleren om de bodem te verlaten.

\subsubsection{Doel experiment}

Het doel van het experiment was:

- Het vaststellen van de mogelijkheid schol en tong dusdanig met luchtbellen te prikkelen dat zij te vangen zijn met een sleepnet

- Het vaststellen het effect van diverse technische instellingen van het lucht-vistuig op de mate waarin schol en tong geprikkeld worden

\subsubsection{Ethische gronden}

Gezien het onderzoek proeven met levende gewervelden betreft valt deze onder de wet op dierproeven (WOD). De dierproeven voor de experimenten zijn in overeenkomst met de Nederlandse Wet op de dierproeven uitgevoerd. Het experiment is goedgekeurd door de Centrale Commissie Dierproeven (Experiment 2017.D-0012.005)

\subsubsection{Locatie}

Het experiment is uitgevoerd bij het Visserij Innovatie Centrum zuidwest Nederland (VIC) in Stellendam. Bij

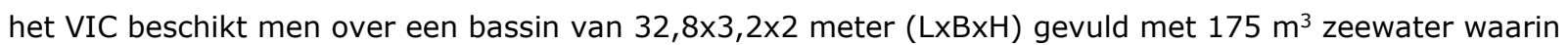
onderdelen van vistuigen of schaalmodellen van vistuigen getest kunnen worden, eventueel met levende vissen. Aan weerszijden van het bassin is een rails bevestigd waarover een wagen kan voortbewegen met een maximale snelheid van 4.5 knoop. Aan deze wagen kunnen (onderdelen van) vistuigen bevestigd worden en door het bassin gesleept worden.

\subsubsection{Proefdieren}

Voor de proef met luchtbellen is gekozen om dit uit te voeren met schol en tong, gezien deze soorten de voornaamste doelsoorten zijn van de puls en boomkorvisserij. De vissen zijn twee weken voor de uitvoering van experiment verzameld in een met pulstuigen uitgerust commercieel vissersschip. Tijdens het verwerken van de vangst zijn de vissen geselecteerd die in de best beschikbare conditie waren, deze zijn aan boord opgeslagen in een beluchte en een met zeewater doorstroomde 600 liter tub. Bij aankomst in de haven van Stellendam zijn de vissen in de tubs naar het VIC vervoerd en gehuisvest in de speciaal daarvoor ingerichte bakken in het VIC. Deze bakken zijn voorzien van grof zand, beluchting en worden doorstroomd met water uit het testbassin, op deze manier wennen de vissen aan de huisvestingsomstandigheden. Tijdens het verblijf in het VIC zijn de vissen gevoerd met zagers.

\subsubsection{Materialen}

Voor de proeven is gebruik gemaakt van een 'Atlas Copco GA7VSDff' compressor (Figuur 26) voor het genereren van luchtruk op de bodem van de tank. De compressor was voorzien van een klep waarmee de luchtdruk naar de proefopstelling gereguleerd kon worden.

Voor de proeven is een speciale kooi (Figuur 27) gemaakt om de vissen binnen een beperkt gebied van het bassin te houden. De kooi bestond uit een metalen frame met daaromheen netwerk. Door het beperken van de ruimte waarin de vissen liggen kan er gericht gekeken worden of de experimentele opstelling met luchtbellen de vissen kan prikkelen. Met het beperken van de zwemruimte kunnen de vissen gemakkelijker teruggevonden worden naar de proef. 
De proefopstelling bestond uit een compressor die middels een slang aan de opstelling in het bassin verbonden was. De opstelling was bevestigd aan de loopwagen en kon daardoor met een ingestelde snelheid boven de bodem bewogen worden. Het geheel bestond uit twee verticale stalen buizen waartussen een horizontale pvc-buis bevestigd was welke boven de bodem van het bassin langs ging, de slang van de compressor was aan de stalen buizen bevestigd. De perslucht werd door de gaten in de pvc-buis richting de bodem van het bassin geblazen. De stalen buizen waren aan de loopwagen bevestigd middels klemmen, door het verstellen van de buizen kon de hoogte boven de bodem van de pvc-buis met gaten gevarieerd worden. Daarnaast kon de oriëntatie van de gaten in de pvc-buis ten opzichte van de bodem aangepast worden, waardoor de lucht uit de gaten naar voren, recht naar beneden of naar achteren geblazen kon worden.

Op de loopwagen en kooi waren 4 onderwatercamera's bevestigd waarmee de proeven en effecten vastgelegd werden uit verschillende hoeken. In de controlekamer van het VIC konden de beelden live bekeken (Figuur 27) worden en na de proef teruggekeken worden om de effecten de beoordelen. De beelden zijn gearchiveerd voor toekomstig gebruik.
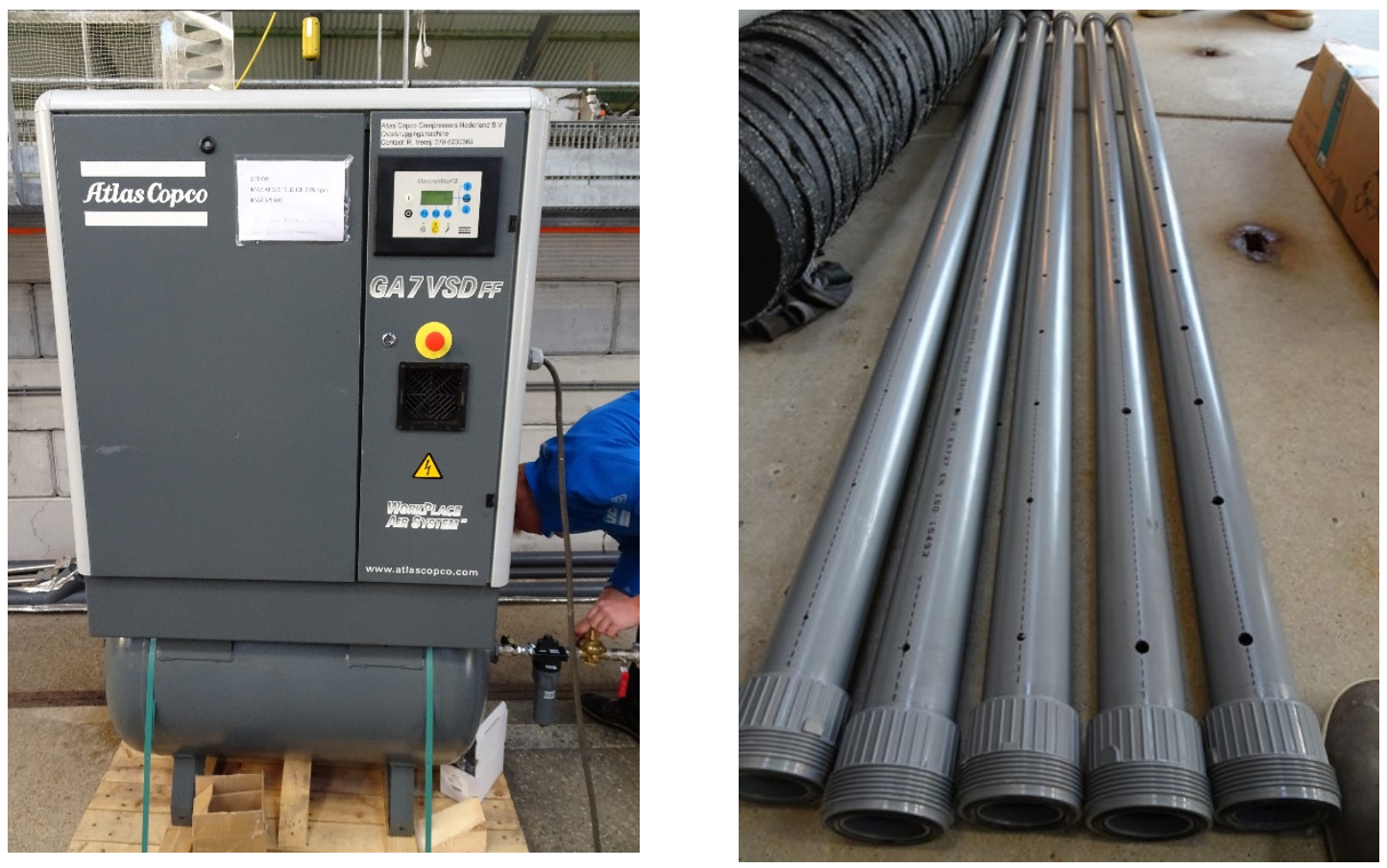

Figuur 26. Compressor (links) en pvc-buizen met gaatjes met verschillende diameter en afstanden voor het testen van luchtbellen als techniek om vis te prikkelen. 


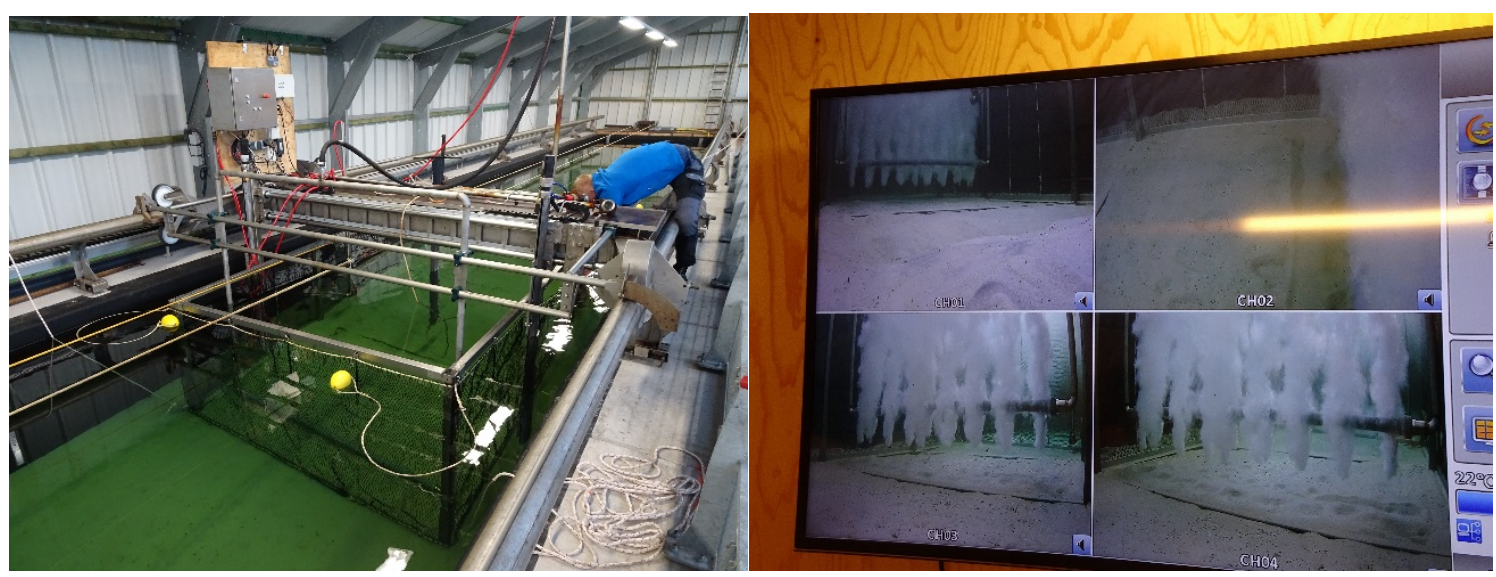

Figuur 27. Links de proefopstelling in het bassin van het VIC. Rechts de schermen uit de controlekamer waarop de effecten van de luchtbellen zichtbaar waren.

\subsubsection{Proefopzet}

Op basis van tests zonder vis is vastgesteld dat een (netto) luchtdruk van 4 a 5 bar nodig is om met luchtbellen opwerveling van zand van de zeebodem te bewerkstelligen. Het experiment is daarom met deze luchtdruk uitgevoerd. De tests hebben ook geleid tot 5 prototypes voor buizen (Figuur 26) waarmee de luchtbellen gemaakt worden. Deze buizen verschillen in het aantal gaten waar de lucht uit komt, de diameter en de verdeling van de gaten in de buis. De buizen zijn op 4 hoogtes boven de bodem getest. Naast de rechte buis is een ontwerp getest met $T$ vormige buizen met extra luchtgaten (Figuur 28). In het originele deel van de pijp waren de luchtgaten schuin naar voren gepositioneerd. In eerste instantie is getest met een plaat boven de pvc-pijp om de verblijftijd en route van de luchtbellen boven de bodem te verlengen. In latere proeven is deze plaat weer verwijderd

Voor de proeven werden 5 maatse schollen en 7 ondermaatse tongen in het midden van de kooi in het bassin gezet. De vissen werden losgelaten in een grote buis waardoor ze in het midden van de kooi boven de bodem losgelaten werden, op deze manier waren de vissen gepositioneerd op de juiste locatie in de kooi. Na het overzetten van de vissen in de proefopstelling en tussen de proeven werd een acclimatisatieperiode van 30 minuten tot 1 uur aangehouden. De vissen zijn op voorwaarde dat ze in goede conditie waren maximaal $3 x$ blootgesteld aan luchtbellen, waarbij tussen elke blootstelling een pauze is gehanteerd. Na drie proeven zijn de vissen uit de tank gehaald en vervangen voor nieuwe vissen voor de volgende set proeven.

In het experimentele opstellen werden de testvissen blootgesteld aan de luchtbellen. In de kooi werd de proefopstelling voortbewogen met $0.1 \mathrm{~m} / \mathrm{s}$ boven de vissen terwijl de lucht door de gaten naar buiten geperst werd. De reactie van de vissen op de luchtbellen werd vastgelegd met onderwatercamera's om vast te stellen hoeveel van de vissen in een groep reageerden. Hierbij is geregistreerd of ze reageren en indien dat het geval is hoe hoog de vissen loskomen van de bodem (vissen die niet (hoog genoeg) van de bodem loskomen worden in de praktijk op zee niet gevangen).

\subsubsection{Resultaten}

De testen met luchtbellen hebben plaatsgevonden in het VIC op 16 en 17 oktober 2018. De watertemperatuur in het bassin was 17 graden met aan saliniteit van $23 \mathrm{~g} / \mathrm{l}$. De waterdiepte tot de zandbodem in de proefopstelling bedroeg $170 \mathrm{~cm}$ en de bodem van het bassin was bedekt met $25 \mathrm{~cm}$ gekalibreerd filterzand. Alle proeven zijn uitgevoerd met een snelheid van $0.1 \mathrm{~m} / \mathrm{s}$, deze snelheid is lager dan regulier in de boomkor of pulsvisserij. In totaal zijn er deze dagen 24 testen met luchtbellen gedaan, waarvan er 15 met vissen in het bassin gedaan zijn. 
In eerste instantie is er zonder vissen in de kooi gekeken bij welke afstand tussen de pvc-buis en de bodem de luchtbellen de bodem raakten. Deze proef is uitgevoerd met de pvc-buis met $3 \mathrm{~mm}$ gaten welke $20 \mathrm{~cm}$ uit elkaar gepositioneerd waren. De druk van de compressor liep tijdens de test terug van 5 bar naar 2.5 bar. De resultaten zijn weergegeven in Tabel 14. Op basis van deze proef is er gekozen om de buis voor de eerste proef met vissen op een hoogte van $15 \mathrm{~cm}$ boven de bodem te zetten.

Tabel 14. Test zonder vissen om effectieve hoogte van buis met luchtbellen boven bodem te bepalen.

\begin{tabular}{cc} 
Hoogte buis van bodem & Effect \\
\hline 30 & $\begin{array}{c}\text { Geen verplaatsing van zandkorrels op } \\
\text { bodem }\end{array}$ \\
\hline 20 & $\begin{array}{c}\text { Luchtbellen komen tot } 2 \mathrm{~cm} \text { boven } \\
\text { bodem }\end{array}$ \\
\hline 15 & Luchtbellen raken net de bodem \\
\hline 10 & Luchtbellen maken kuiltje zand \\
\hline
\end{tabular}

De eerste proef met vissen is uitgevoerd met de buis $15 \mathrm{~cm}$ boven de bodem en de overige instellingen zoals tijdens de eerste test voor de hoogte van de buis (Tabel 14). Eerst zijn 5 maatse schollen en 7 ondermaatse tongen in de kooi geplaatst, waarna de vissen 60 minuten konden acclimatiseren. De specificaties per proef zijn te vinden in Tabel 15 en Tabel 16. Daarna werden de vissen blootgesteld aan de luchtbellen uit de proefopstelling welke met een snelheid van $0.1 \mathrm{~m} / \mathrm{s}$ werd voortbewogen boven de bodem. $\mathrm{Na}$ het terugkijken van de opnames van de 4 onderwatercamera's werd geconcludeerd dat geen enkele van de ingezette vissen gereageerd had. Daarom is besloten om de volgende proef uit de voeren met de buis op een hoogte van $12.5 \mathrm{~cm}$ boven de bodem zodat de luchtbellen effectiever de bodem te laten raken. Omdat deze hoogte ook geen reactie gaf van de ingezette vissen (Tabel 17) is de derde proef uitgevoerd met de buis op een hoogte van $10 \mathrm{~cm}$ en is de oriëntatie van de gaatjes aangepast zodat de luchtbellen schuin naar voren geblazen werden. Dit omdat de voortbeweging van de experimentele setting ervoor zorgt dat de luchtbellen schuin naar achteren geblazen worden ondanks dat de luchtgaten recht naar beneden georiënteerd zijn. Als resultaat van de aanpassingen had 1 tong zich verplaatst na het passeren van de opstelling en luchtbellen. Echter, was de reactie van de vissen naar oordeel van de aanwezige visserijexperts te beperkt voor een succesvolle visserij. Daarom is besloten om de daaropvolgende proeven uit te voeren met de buis op een hoogte van $3 \mathrm{~cm}$ van de bodem (Tabel 15). In proef $4 \mathrm{t} / \mathrm{m} 7$ is gevarieerd met de oriëntatie van de luchtgaten met als resultaat dat per proef één of soms twee tongen verplaatst waren t.o.v. hun originele positie (Tabel 17). In proef 8 werd waargenomen dat twee tongen mee werden genomen door de opwaartse kracht van water en lucht die na het passeren van de proefopstelling aanwezig was. Bij proef 8, 10 en 11 zijn er twee rubberen matten boven de buis gemaakt om de route en verblijftijd van de luchtbellen bij de bodem aan te passen. Het effect was beperkt en er werd geen vooruitgang gevonden. Voor proef $12 \mathrm{t} / \mathrm{m} 15$ is er een aangepaste buis met T stuken gemaakt waarmee zowel luchtbellen uit de $\mathrm{T}$ stukken als de originele buis geblazen werden (Figuur 28). Het effect op de vissen was vergelijkbaar t.o.v. de eerder proeven, één of een aantal keer twee tongen waren verplaatst en de overige vissen vertoonden geen reactie (Tabel 17). 


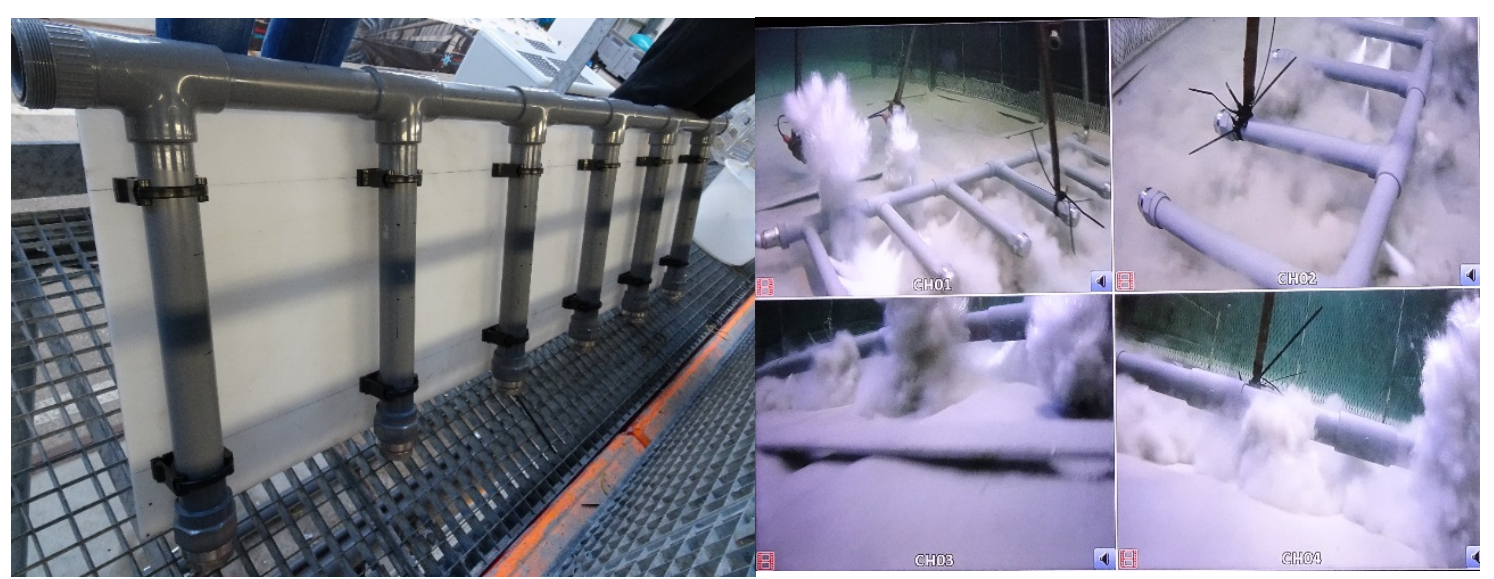

Figuur 28. Rechts de aangepaste pvc-pijp voor proef $12 \mathrm{t} / \mathrm{m} 15$ met $\mathrm{T}$ stukken met luchtgaten die opzij blazen. In het originele deel van de pijp waren de luchtgaten schuin naar voren gepositioneerd. In eerste instantie is getest met een plaat boven de pvc-pijp om de verblijftijd en route van de luchtbellen boven de bodem te verlengen. In latere proeven is deze plaat weer verwijderd. Links de beelden van de 4 camera's op het moment dat de eerste luchtbellen uit de proefopstelling komen.

Tabel 15. Specificaties van de proeven met luchtbubbels: aantal vissen, aantal blootstellingen, hoogte van de buis boven de bodem, afstand tussen de luchtgaten in de buis, diameter van de luchtgaten en de druk bij de uitgang van de compressor. De druk bij de uitgang van de compressor liep terug gedurende de proef. Na proef 7 is er één tong uit de testopstelling verwijderd, proef 8 en 9 zijn daarom met 6 tongen uitgevoerd.

\begin{tabular}{cccccccc}
$\begin{array}{c}\text { Proef } \\
\text { nr. }\end{array}$ & $\begin{array}{c}\text { Aantal } \\
\text { schol }\end{array}$ & $\begin{array}{c}\text { Aantal } \\
\text { tong }\end{array}$ & $\begin{array}{c}\text { Bloot- } \\
\text { stellings } \\
\text { nr. }\end{array}$ & $\begin{array}{c}\text { Hoogte buis } \\
\text { boven } \\
\text { bodem }(\mathrm{cm})\end{array}$ & $\begin{array}{c}\text { Afstand } \\
\text { tussen } \\
\text { lucht- } \\
\text { gaten } \\
\text { (cm) }\end{array}$ & $\begin{array}{c}\text { Diameter } \\
\text { luchtgaten }\end{array}$ & $\begin{array}{c}\text { Druk } \\
\text { (bar) }\end{array}$ \\
\hline 1 & 5 & 7 & 1 & 15 & 20 & 3 & 5 tot 2.5 \\
\hline 2 & 5 & 7 & 2 & 12.5 & 20 & 3 & 5 tot 2.5 \\
\hline 3 & 5 & 7 & 3 & 10 & 20 & 3 & 5 tot 2.5 \\
\hline 4 & 5 & 7 & 1 & 3 & 20 & 3 & 5 tot 2.5 \\
\hline 5 & 5 & 7 & 2 & 3 & 10 & 3 & 5 tot 1.5 \\
\hline 6 & 5 & 7 & 3 & 3 & 10 & 3 & 5 tot 1.5 \\
\hline 7 & 5 & 7 & 1 & 3 & 10 & 3 & 5 tot 1.5 \\
\hline 8 & 5 & 6 & 2 & 3 & 10 & 3 & 5 tot 1.5 \\
\hline 9 & 5 & 6 & 3 & 3 & 10 & 3 & 5 tot 1.5 \\
\hline 10 & 5 & 7 & 1 & 3 & 10 & 3 & 5 tot 1.5 \\
\hline 11 & 5 & 7 & 2 & 3 & 10 & 3 & 5 tot 1.5 \\
\hline 12 & 5 & 7 & 3 & 3 & T-stuk & 3 & 5 tot 1.0 \\
\hline 13 & 5 & 7 & 1 & 3 & T-stuk & 3 & 5 tot 1.0 \\
\hline 14 & 5 & 7 & 2 & 3 & T-stuk & 3 & 5 tot 1.2 \\
\hline 15 & 5 & 7 & 3 & 3 & T-stuk & 3 & 5 tot 0.5 \\
\hline
\end{tabular}


Tabel 16. Oriëntatie luchtgaten ten opzichte van de sleeprichting van de proefopstelling en overige aanpassingen aan de proefopstelling.

\begin{tabular}{|c|c|c|}
\hline Proefnr. & Oriëntatie luchtgaten & Overige aanpassingen \\
\hline 1 & Recht naar beneden & n.v.t. \\
\hline 2 & Recht naar beneden & n.v.t. \\
\hline 3 & Schuin naar voren & n.v.t. \\
\hline 4 & Schuin naar voren & n.v.t. \\
\hline 5 & Schuin naar voren & n.v.t. \\
\hline 6 & Recht naar beneden & n.v.t. \\
\hline 7 & Schuin naar achteren & n.v.t. \\
\hline 8 & Schuin naar achteren & $2 x$ rubber mat $41 \times 88 \mathrm{~cm}$ op buis bevestigd \\
\hline 9 & Schuin naar achteren & $2.5 \mathrm{~m} 10 \mathrm{~mm}$ ketting achter buis bevestigd \\
\hline 10 & Schuin naar achteren & $\begin{array}{l}2 \times \text { rubber mat } 41 \times 88 \mathrm{~cm} \text { op buis bevestigd } \& \\
\text { ketting op mat voor neerwaartse druk }\end{array}$ \\
\hline 11 & Schuin naar achteren & $2 x$ rubber mat $41 \times 88 \mathrm{~cm}$ op buis bevestigd \\
\hline 12 & $\begin{array}{l}\text { Schuin naar voren \& T-stuk met } \\
\text { luchtgaten schuin naar de zijkant }\end{array}$ & $\begin{array}{l}\text { Extra plaat boven buis + extra T stukken aan } \\
\text { luchtbuis }\end{array}$ \\
\hline 13 & $\begin{array}{l}\text { Schuin naar voren \& T-stuk met } \\
\text { luchtgaten schuin naar de zijkant }\end{array}$ & extra T stukken aan luchtbuis \\
\hline 14 & $\begin{array}{l}\text { Schuin naar voren \& T-stuk met } \\
\text { luchtgaten schuin naar de zijkant }\end{array}$ & $\begin{array}{c}\text { extra T stukken aan luchtbuis \& meer } \\
\text { luchtdruk }\end{array}$ \\
\hline 15 & $\begin{array}{l}\text { Schuin naar voren \& T-stuk met } \\
\text { luchtgaten schuin naar de zijkant }\end{array}$ & Minder luchtdruk met rubber flappen \\
\hline
\end{tabular}


Tabel 17. Observaties per proef van de effecten van luchtbubbels op vissen en proefopstelling.

\begin{tabular}{|c|c|}
\hline Proefnr. & Bevindingen \\
\hline 1 & Geen zichtbare reactie vissen \\
\hline 2 & Geen zichtbare reactie vissen \\
\hline 3 & $\begin{array}{l}\text { Eén tong verplaatst. Zand wordt van vissen geblazen, als gevolg graven ze } \\
\text { dieper in de bodem. }\end{array}$ \\
\hline 4 & Eén tong 2 meter verplaatst. Geen zichtbare reactie overige vissen. \\
\hline 5 & $\begin{array}{l}\text { Eén tong springt op en komt los van de bodem, overige vissen niet } \\
\text { verplaatst. }\end{array}$ \\
\hline 6 & $\begin{array}{l}\text { Twee tongen verplaatst door lucht/waterstroom. Bodemberoering } 10-25 \\
\text { cm als loopwagen stil staat. Overige vis schoon geblazen met waterstraal en } \\
\text { lucht maar graven zich weer in. Overige vis niet verplaatst. }\end{array}$ \\
\hline 7 & $\begin{array}{l}\text { Twee tongen mee genomen door opwaartse lucht en waterstroom, één } \\
\text { duidelijk } 1.5 \text { meter omhoog geblazen. Bodemberoering } 10-25 \mathrm{~cm} \text { diep, } \\
\text { overige vis geen zichtbare reactie. }\end{array}$ \\
\hline 8 & $\begin{array}{l}\text { Twee schollen en een tong naar achterste vak van de kooi verplaatst. } \\
\text { Werveling en stroming gaan onder rubbermat door, met als gevolg geen } \\
\text { grondcontact van bubbels. Misschien wordt oriëntatie buis te ver } \\
\text { horizontaal gedraaid door opwaartse kracht lucht onder rubbermat. } \\
\text { Toepassen mat lijkt geen vooruitgang }\end{array}$ \\
\hline 9 & Eén tong verplaatst, de overige vissen niet. \\
\hline 10 & Geen reactie vissen. \\
\hline 11 & Geen reactie vissen. \\
\hline 12 & $\begin{array}{l}\text { Luchtbellen drukken plaat en buis omhoog waardoor hele opstelling schuim } \\
\text { omhoog komt te staan, geen goede proef. }\end{array}$ \\
\hline 13 & Twee tongen verplaatst naar buitenzijden van de kooi \\
\hline 14 & Eén tong verplaatst, de overige vissen niet. \\
\hline 15 & Geen reactie, alle vis op zelfde plek. \\
\hline
\end{tabular}

\subsubsection{Conclusie}

Platvis ligt van nature in of op de bodem, om gevangen te worden dient te platvis gestimuleerd te worden om los van de bodem te komen zodat deze over de grondpees van een sleepnet gaat en daardoor gevangen kan worden in het net. Indien de platvis op of in de bodem blijft liggen gaat de grondpees over de vissen heen en worden ze niet gevangen. Om de platvis en met name tong los van de zeebodem te krijgen worden in een traditioneel boomkor wekkerkettingen gebruikt, en met de puls elektrische stroomstootjes. In deze proef is geprobeerd om met luchtdruk en dus luchtbellen boven de bodem de vis te stimuleren om de bodem te verlaten. Echter, laten de proeven zien dat in deze opstelling een zeer beperkt aantal vissen reageert op de luchtbellen. In enkele gevallen kwam er een tong los van de bodem en werd door de luchtbellen meegenomen naar boven. Overige observaties lieten zien dat de luchtbellen het zand van de ingegraven vissen blies waarop de vissen zich opnieuw in het zand ingroeven. Hierdoor is de kans groot dat de grondpees van een vistuig over de vissen heen gaat en ze niet gevangen worden in het net. Daarmee lijkt deze methode in deze opstelling nog geen alternatief voor wekkerkettingen of puls gezien de beperkte effectiviteit waarmee tong en schol gestimuleerd worden om de bodem te verlaten. 


\section{Noorse Kreeften visserij}

\subsection{Inleiding}

De gemengde visserij op Noorse kreeft wordt voornamelijk in het vroege voorjaar tot het begin van de winter beoefend, al zijn er enkele schepen die in de wintermaanden doorvissen. Er wordt gevist met specifieke ottertrawls (OTB) in een twin- of quad- (4) of multi-rig (6) optuiging waarbij de netten zijn voorzien van kuilen met een maaswijdte van $80 \mathrm{~mm}$. De samenstelling van de marktwaardige vangst is afhankelijk van het tijdstip van de dag, maar bestaat hoofdzakelijk uit Noorse kreeft en schol met beperkte bijvangsten van tarbot, griet en rondvis (Verkempynck et al., 2018; Molenaar at al, 2016). Bijvangsten bestaan voornamelijk uit niet marktwaardige Noorse kreeft, ondermaatse schol en schar en in minder mate uit wijting, grauwe poon, rog en andere benthische organismen (Verkempynck et al., 2018; Molenaar at al, 2016). Onder de huidige aanlandplicht (European Union, 2013) vormen voornamelijk de ongewenste bijvangst van ondermaatse schol en niet marktwaardige Noorse kreeft een aandachtspunt. In het project 'Vermindering discards door netinnovatie in de Noorse Kreeft visserij' zijn er volgens het WMR innovatietraject (Figuur 1) verschillende netontwerpen en innovaties getest om de bijvangst van ondermaatse schol, schar en niet marktwaardige Noorse kreeften te beperken (Molenaar et al. 2016). Uit dit project zijn twee bijvangst beperkende innovaties gekomen dit binnen NIKO2 verder uitgewerkt worden. In het geval van SepNep ging het om een verdere optimalisatie van de werking en het breder uittesten onder de schepen die op Noorse Kreeft vissen, in het geval van het Swedish grid diende de innovatie aangepast te worden aan de Nederlandse situatie en werd de werking getest.

\subsection{Deelnemende schepen}

Verschillende schepen hebben bijgedragen door binnen dit project netinnovaties te testen die waren gericht op het beperken van bijvangst in de Noorse kreeften visserij. In totaal hebben acht pulskotters bijgedragen aan het project, de specificaties van de deelnemende schepen zijn hieronder weergegeven in Tabel 18 .

Tabel 18. Deelnemende schepen aan netinnovatie in de Noorse kreeften visserij.

\begin{tabular}{|c|c|c|c|c|c|c|c|c|}
\hline Kenmerk/ & N350 & UK210 & UK158 & WR274 & WR189 & WR18 & WR108 & ZK2 \\
\hline \multirow[t]{2}{*}{ Schip } & Ingrid & Cristina & Willem & Dirk & Grietje & In- & Stella & Portunus \\
\hline & & Maria & Jacob & Senior & & Solidum & Maris & \\
\hline Lengte (m) & 24 & 23 & 24 & 24 & 24 & 25 & 23 & 21 \\
\hline Breedte (m) & 6.0 & 8.5 & 7 & 6.0 & 6.6 & 5.5 & 6 & 6.0 \\
\hline Diepte $(\mathrm{m})$ & 2.6 & 3.5 & 3.7 & 2.7 & 3.1 & 2.6 & 2.6 & 2.7 \\
\hline Inhoud (GT) & 104 & 192 & 161 & 105 & 137 & 64 & 83 & 82 \\
\hline Motorvermogen (pk) & 300 & 533 & 468 & 300 & 300 & 300 & 300 & 300 \\
\hline
\end{tabular}

\subsection{SepNep}

Als reactie op de aanlandplicht is er in een samenwerkingsverband tussen wetenschap en visserijsector in het project 'Less Fuel \& Discards in visserij op Noorse kreeft' en 'Vermindering discards door netinnovatie in de Noorse Kreeft visserij' gezocht naar selectievere netontwerpen voor de visserij op Noorse Kreeft (Steenbergen et al, 2012; Molenaar et al, 2018). Uit de verschillende netontwerpen die getest zijn kwam het SepNep als effectief naar voren.

SepNep is een concept waarbij een bestaand net voor Noorse kreeft uitgerust wordt met een taps toelopend paneel waarmee de gemengde vangst van vis en Noorse Kreeft gescheiden wordt. Dit 
scheidingpaneel scheidt de vangst in vis en Noorse kreeft, beide fracties worden in een aparte kuil opgevangen. De Noorse kreeften worden opgevangen in een kuil met een maaswijdte van $80 \mathrm{~mm}$ en de vis in een kuil met $120 \mathrm{~mm}$. Door de relatief grote maaswijdte van de kuil voor de vis kunnen de ondermaatse vissen grotendeels ontsnappen en wordt de ongewenste bijvangst door dit netontwerp verminderd. Tijdens de vangstvergelijkingsreis werd er met het SepNep een vermindering van ongewenste bijvangst bereikt van $65 \%$. Als er specifiek naar schol gekeken werd dan verminderde het SepNep net de bijvangst van ondermaatse schol met $69 \%$ en werd er $78 \%$ minder ondermaatse schar gevangen. Echter werd er in de SepNep netten 20\% minder marktwaardige Noorse kreeft en 13\% meer niet marktwaardige Noorse kreeft gevangen (Molenaar et al. 2016). Dergelijke verliezen zijn waarschijnlijk te hoog voor een brede acceptatie en toepassing van SepNep binnen de vloot. Daarom is verdere optimalisatie van het concept noodzakelijk. De specificaties van het SepNep paneel worden in Tabel 19 en Figuur 29 weergegeven.

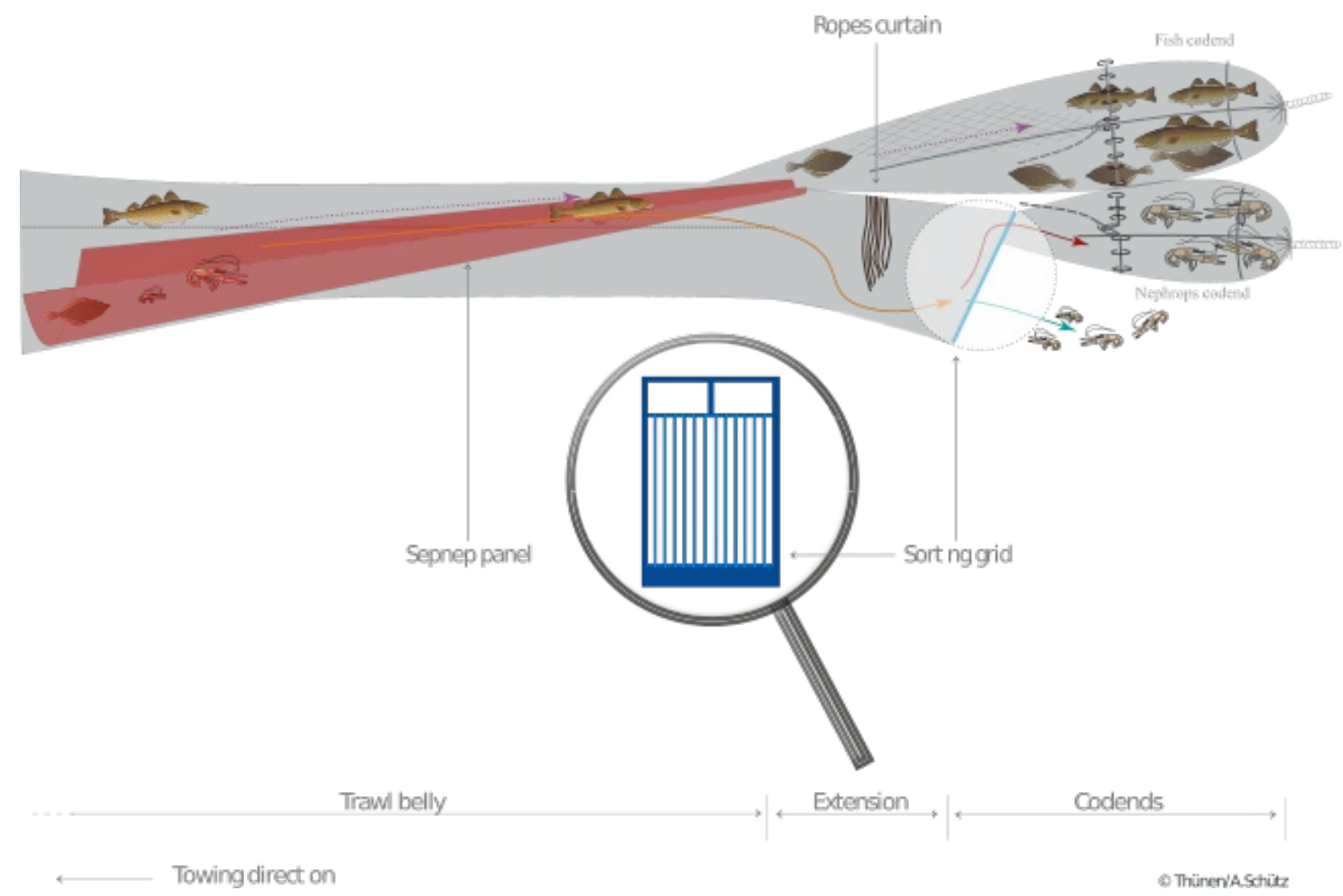

Figuur 29, Tekening SepNep concept. Het scheidingspaneel voor vis in Noorse kreeft is weergegeven in rood, het optionele sorteerrooster is weergeven in blauw (Santos \& Molenaar, 2016). 
Tabel 19, Specificaties scheidingspaneel, onder- en bovenkuil en het optionele grid van het SepNep netontwerp.

\begin{tabular}{|c|c|}
\hline Kenmerkt per onderdeel van het tuig & Specificatie \\
\hline \multicolumn{2}{|l|}{ Bovenkuil (vis kuil) } \\
\hline Minimum maaswijdte & $120 \mathrm{~mm}$ (tussen de knopen) \\
\hline Maximale omtrek kuil & 80 mazen rond (inclusief naden) \\
\hline \multicolumn{2}{|l|}{ Onderkuil (Noorse kreeften kuil) } \\
\hline Minimum maaswijdte & $80 \mathrm{~mm}$ (tussen de knopen) \\
\hline Maximale omtrek kuil & 110 mazen rond (inclusief naden) \\
\hline \multicolumn{2}{|l|}{ SepNep scheidingspaneel } \\
\hline Maximale maaswijdte & $105 \mathrm{~mm}$ (tussen de knopen) \\
\hline Minimum lengte paneel & 100 mazen \\
\hline Voorzijde paneel & $\begin{array}{l}\text { Maximaal } 88 \% \text { van netbreedte, dit komt } \\
\text { overeen met } 2 \text { mazen in het paneel }(105 \mathrm{~mm}) \\
\text { bevestigd op } 3 \text { mazen van het net }(80 \mathrm{~mm})\end{array}$ \\
\hline achterzijde paneel & 16 mazen breed \\
\hline \multicolumn{2}{|l|}{ Sorteer rooster Noorse kreeft } \\
\hline Minimale spijlafstand & $17 \mathrm{~mm}$ \\
\hline
\end{tabular}

Dit ontwerp is buiten NIKO II getest en verbeterd op het Duitse onderzoeksschip Solea (Santos \& Molenaar, 2016). Echter diende het ontwerp nog wel geoptimaliseerd en breder in de vloot getest te worden om vlootbreed in de verschillende Noorse kreeften netten effectief te functioneren. De optimalisatie werd in NIKO II uitgevoerd door de WR189 en de UK158 waar een vangstvergelijking is uitgevoerd. De overige deelnemende schepen hebben de SepNep netten uitgeprobeerd waarbij zij feedback gaven op de werking en toepasbaarheid in de werkwijze van het schip.

\subsubsection{Vangstvergelijking markwaardige Noorse kreeft}

De UK158 heeft in week 36 van 2017 een vangst vergelijking gedaan met aan bakboord twee SepNep netten en aan stuurboord twee conventionele netten. Op basis van een self-samplingsprotocol van WMR heeft de bemanning de vangsten bijgehouden uit de twee verschillende netten. Elke trek is stuurboord en bakboord apart verwerkt en is de vangst van marktwaardige Noorse kreeft per kant gewogen. Daarnaast zijn er 3 trekken bemonsterd op basis van een discardsample (paragraaf 0 ). Het beperkte aantal trekken dat bemonsterd is maakt de analyse en interpretatie van deze resultaten echter moeilijk.

\subsubsection{Resultaten bemonstering marktwaardige kreeft}

In week 36 zijn er totaal 16 trekken gedaan van 4 tot 5 uur. De vangsten van marktwaardige Noorse kreeft varieerden met het tijdstip van de dag, waarbij er in de trekken bij daglicht zoals gewoonlijk aanzienlijk minder Noorse kreeft gevangen werd. In de drie trekken $(7,11$ en 15) waarbij de onder en bovenkuil van de SepNep netten apart verwerkt werden werd $10 \%, 16 \%$ en $28 \%$ van de marktwaardige kreeft in de $120 \mathrm{~mm}$ bovenkuil aangetroffen(Figuur 30). Ondanks dat een deel van de marktwaardige kreeften in de wijde bovenkuil gevangen zijn leidt dit niet tot een aanzienlijk vangstverlies, in Figuur 30 is te zien dat de vangt van Noorse kreeft in trek 7 iets minder is, trek 11 gelijk en in trek 15 er zelfs meer kreeft gevangen is in de SepNep netten. Gemiddeld over de hele week is er per trek 59.1 kilogram kreeft in de SepNep en 60.8 kilogram in de conventionele netten, gemiddeld over deze week vangen de SepNep netten $2.7 \%$ minder Noorse kreeft in vergelijking met conventionele netten. 


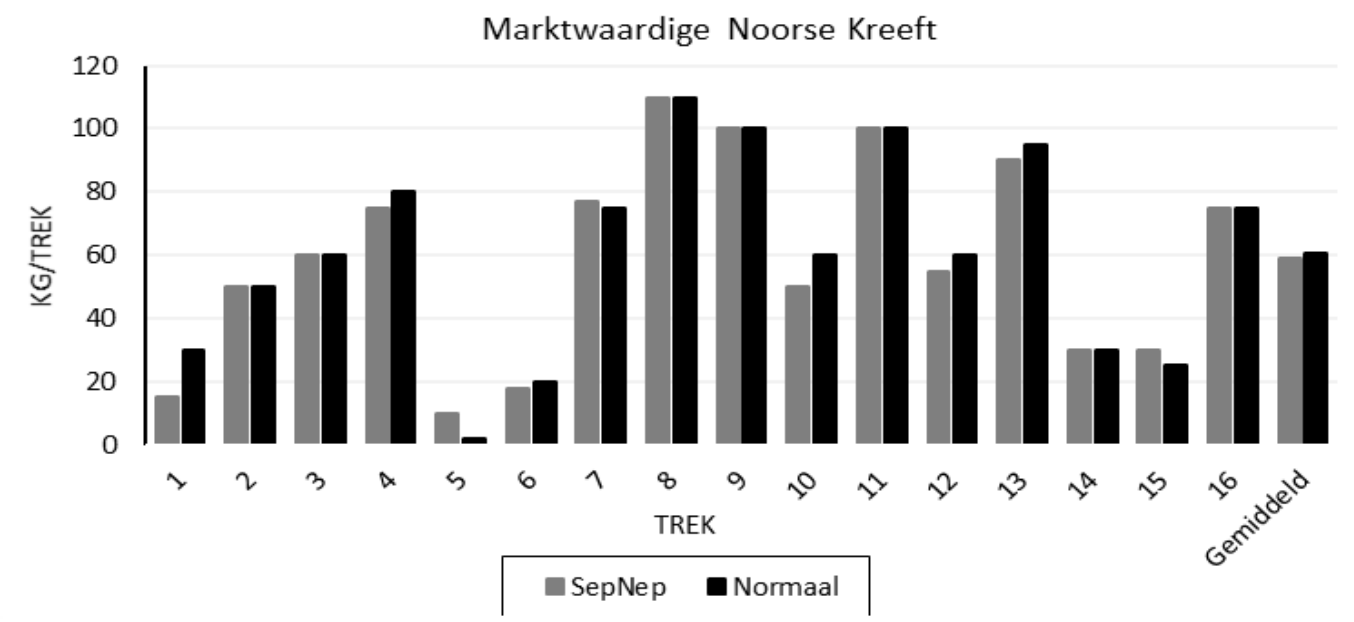

Figuur 30. Vangst marktwaardige Noorse kreeft in kilogram per trek voor de SepNep netten (2) en conventionele netten (2).

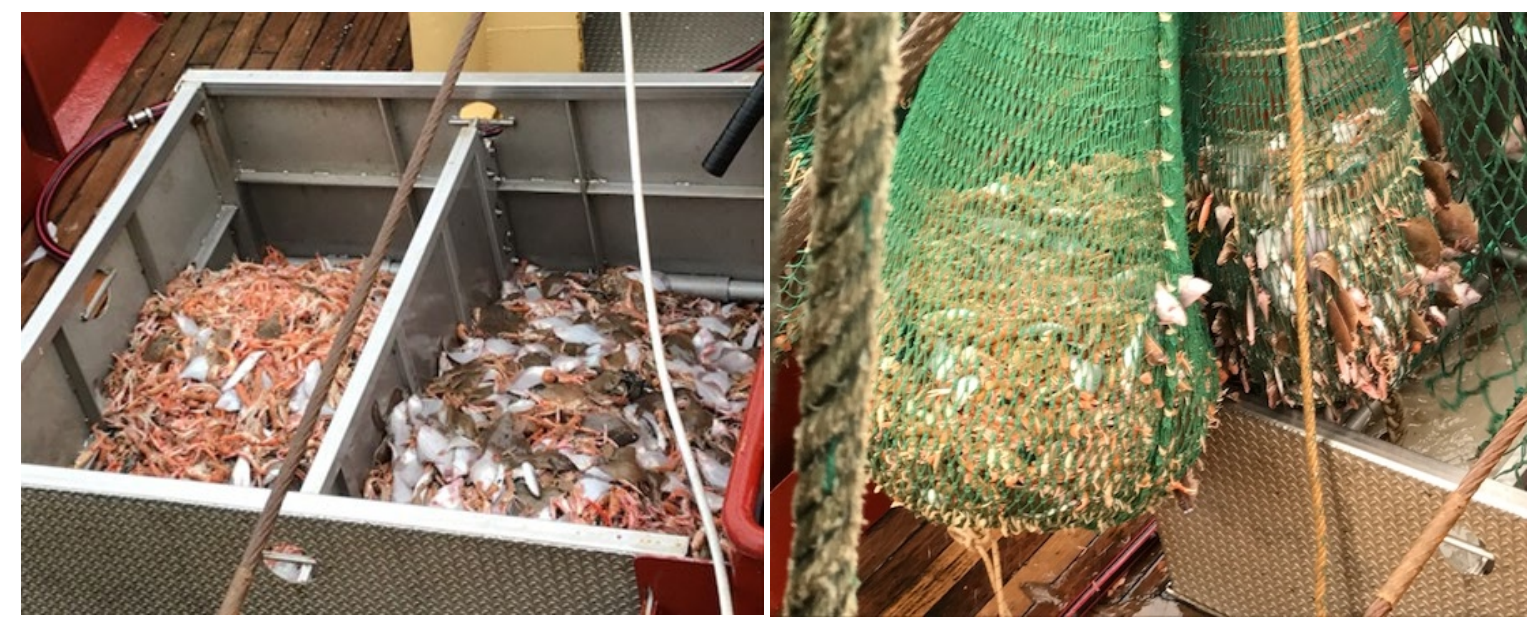

Figuur 31. SepNep proeven UK158. Linker foto, links in de stortbak is de vangst uit de $80 \mathrm{~mm}$ onderkuil van het SepNep net en rechts de vangst uit de $120 \mathrm{~mm}$ Kuil. Rechter foto laat de twee kuilen van het SepNep net zien, links de $90 \mathrm{~mm}$ kuil en rechts de $120 \mathrm{~mm}$ kuil voor de vis.

\subsubsection{Optimalisatie SepNep}

De ontwikkeling en optimalisatie voor commerciële toepassing van het SepNep ontwerp richt zich op twee aspecten; (i) het scheidingspaneel en (ii) het grid. Gedurende de looptijd van het project heeft de WR189 jaarrond (als er op kreeft gevist werd) met de SepNep netten gevist. Gedurende deze reizen is aan deze twee aspecten van het SepNep gewerkt in hun commerciële Noorse kreeftennetten waarbij de voornaamste focus lag op het scheidingspaneel.

\subsubsection{SepNep paneel}

Voor de optimalisatie van het netontwerp zijn vier kreeftennetten en twee reserve netten voor de WR189 gemaakt volgens het SepNep principe. In enkele panelen zijn kleine variaties aangebracht om te zoeken naar een optimale scheiding van Noorse kreeft en vis waarbij alle Noorse kreeften in de onderkuil komen. Uit de testen op het Duitse onderzoeksschip Solea kwam naar voren dat het plaatsen van drijvers onder het paneel de scheiding van Noorse kreeft en de overige vangst effectiever maakte (Santos \& Molenaar, 2016). Zodoende is dit ook toegepast in de netten van de WR189. Er is geëxperimenteerd met de positie van de drijvers, naast positionering zoals weergegeven in Figuur 32. Geoptimaliseerd SepNep sorteer paneel met aan de onderzijde drijvers bevestigd om extra verhoging van het paneel te bewerkstelligen. De effectiviteit van het paneel voor het scheiden van Noorse Kreeft en de overige vangst wordt hiermee verbeterd. is er getest met een paneel waarbij de drijvers in een lange lijn geplaatst waren. Dit leek een positief effect te hebben aldus de schipper van de WR189. Naast de experimenten met drijvers is er een paneel gemaakt waarbij de mazen een kwartslag gedraaid zijn (T45), hierdoor staan de mazen in het paneel vierkant open. 

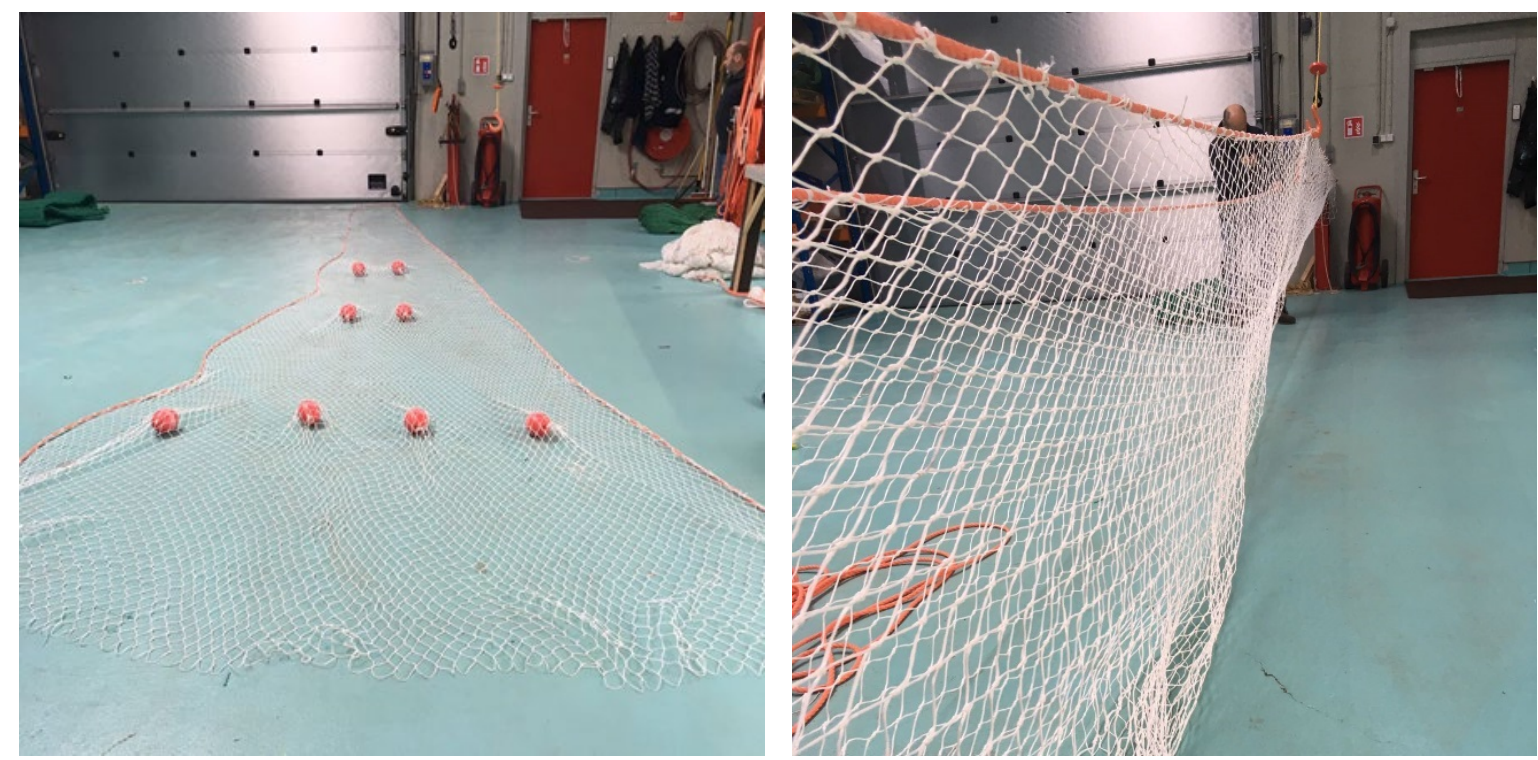

Dit paneel bleek zeer effectief te werken, echter is het in het net maken van een paneel met vierkante mazen moeilijker in vergelijking met een paneel met ruitvormige (TO) mazen.

Figuur 32. Geoptimaliseerd SepNep sorteer paneel met aan de onderzijde drijvers bevestigd om extra verhoging van het paneel te bewerkstelligen. De effectiviteit van het paneel voor het scheiden van Noorse Kreeft en de overige vangst wordt hiermee verbeterd.

\subsubsection{SepNep grid}

Voor het beperken van de bijvangst van ondermaatse kreeft is er in het voorgaande project een sorteer rooster ontwikkeld (Molenaar et al, 2016). De selectiviteit van het rooster is op het Duitse onderzoeksschip Solea uitvoerig getest waarbij een ruimte van $17 \mathrm{~mm}$ tussen de spijlen effectief bleek te zijn (Santos \& Molenaar, 2016). Tijdens de proeven bleek dat de stevigheid en stabiliteit van het grid verbeterd kon worden. Voor een effectieve commerciële toepassing van het grid moet het stabiel in het net staan onder de juiste hellingshoek. Om dit te bereiken is het grid in een roestvrijstalen frame geplaatst, om het gewicht op te heffen en het grid stabiel te houden zijn er aan de bovenzijde drijvers bevestigd (Figuur 33). Een bijkomend voordeel is dat het frame met het grid beschermd wordt tegen krachten bij het halen en het zetten van de netten. De sorterende werking van het grid was goed aldus de schipper, alleen leek het grid soms een schepje modder van de zeebodem mee te nemen. Waarschijnlijk is er iets meer drijfvermogen nodig om het grid beter te positioneren. Eventueel kan er ook een sleeplap onder het grid bevestigd worden om het scheppen van modder te voorkomen. Verdere ontwikkeling en optimalisatie zou gericht kunnen worden op de hellingshoek, doorstroming en spijlopeningen $(18 \mathrm{~mm})$. 


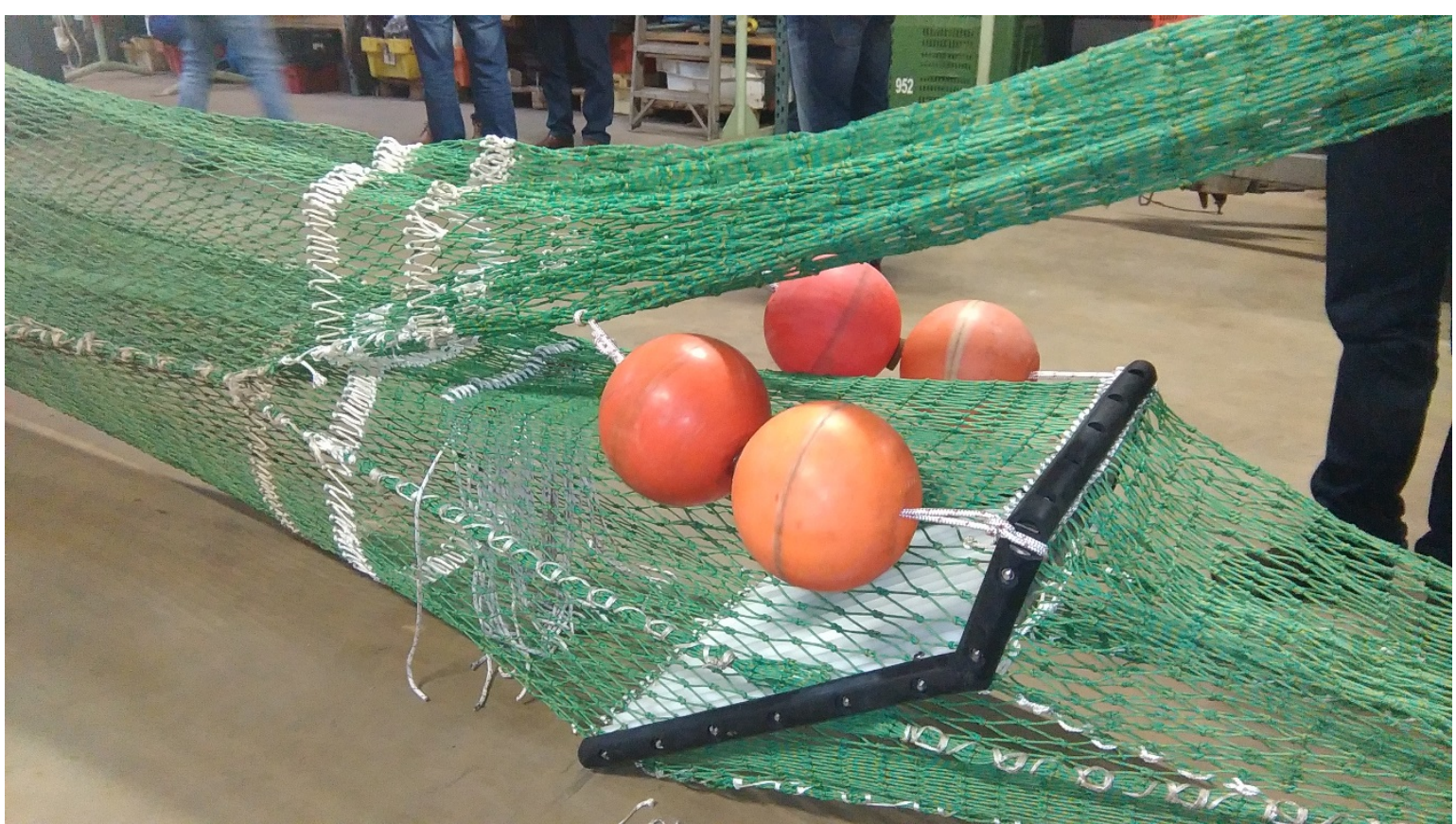

Figuur 33, SepNep sorteerrooster (wit) om de bijvangst van niet marktwaardige Noorse Kreeft te beperken. Te kleine kreeftjes passeren de openingen tussen de spijlen van het grid en ontsnappen, markwaardige kreeften kunnen er niet door heen, schuiven naar boven en komen in de $80 \mathrm{~mm}$ kreeftenkuil terecht. Om het grid te beschermen is het plastic grid geplaatst in een rvs-beschermframe. De extra drijvers zijn aangebracht om het grid in positie te houden en voorkomen dat het grid zijwaarts kan bewegen tijdens het vissen.

\subsubsection{Bevindingen SepNep testen breder in de vloot}

Gedurende de looptijd van het project is het SepNep ontwerp opgenomen in de discardplannen van de Scheveningen groep (Joint Recommendation of the Scheveningen Group, 2018). Hierdoor is het netontwerp opgenomen in de huidige regelgeving en mag er legaal commercieel met het SepNep netontwerp gevist worden. Hierdoor verviel voor de deelnemende vissers de verplichting om deel te nemen aan onderzoek om het netontwerp te mogen gebruiken. Dit heeft zijn weerslag gehad op de terugkoppeling van de selfsamplingsresultaten waardoor een beperkte terugkoppeling heeft plaatsgevonden.

Een tiental schepen heeft gedurende de looptijd van het project het SepNep scheidingspaneel in hun net laten maken. Echter is er veel verschil in netontwerpen tussen de kotters, waardoor het ontwerp van het scheidingspanel niet altijd 1 op 1 overgenomen kon worden. De SepNep scheidingspanelen zijn daarom op maat gemaakt door netmaker J. Vlaming (JV Visserijconsulent) voor specifieke kotters. Een aantal heeft er mee gevist, waarbij er wisselende positieve en negatieve resultaten gehaald werden (bijlage 6). De oorzaak van het behalen van een negatief resultaat kan in twee richtingen gezocht worden, een suboptimaal SepNep scheidingspaneel ontwerp voor het specifieke net van de kotter of het beperkt schoon houden van het paneel. Dit laatste kan ontstaan door praktische aspecten aan boord tijdens het ophalen, legen en uitzetten van de netten die het schoon maken bemoeilijken.

Voor een optimale werking van het paneel moet het schoon zijn bij het uitzetten van het net. Indien er debris, krabben of roggen in het paneel hangen tijdens het halen van de netten, moeten deze richting de kuil geleid worden. Door deze handeling is het paneel bij de volgende trek schoon en werkt het optimaal. Indien dit niet gedaan worden drukt 'verstrikte' vangst mogelijk het paneel tegen de onderzijde van het net en word de werking verminderd waardoor een groot deel van de vangst in de wijde $120 \mathrm{~mm}$ bovenkuil terecht komt met vangstverlies als gevolg. Dit vangstverlies is mogelijk een gevolg van de opstelling van de nettenrol op sommige schepen, in een aantal gevallen is die dusdanig (laag) waardoor de bemanning tijdens het halen van net netten niet bij het net of paneel kan komen. Hierdoor kan men in het geval van 'verstrikte' vangst deze niet naar de kuil geleiden. Hiervoor moet een extra handeling na het halen van het net gedaan worden, gezien dit vistijd kost wordt het paneel dan niet schoon gemaakt. Dit kan een verminderde werking van het paneel en negatieve ervaring tot gevolg kan hebben. Omdat aanpassingen aan het nettenrol (hoger plaatsen) niet altijd direct mogelijk zijn sommige vissers afwachtend met het 
gebruik van SepNep netten. Ondanks de schonere vangsten die de vangstverwerking verkorten en een betere viskwaliteit, moeten er tijdens het halen en zetten van de netten enkele extra handelingen verricht worden. Het lijkt er daarom op dat deze schepen SepNep pas commercieel toe willen passen indien de aanlandplicht daadwerkelijk gehandhaafd wordt.

\subsection{Swedish Grid}

Van 15 tot 18 april 2018 heeft De Nederlandse Vissersbond als onderdeel van NIKO II een groepsreis naar Zweden georganiseerd voor vissers, visserijvertegenwoordigers en nettenmakers die geïnteresseerd zijn in het ontwikkelen van selectievere netten voor Noorse Kreeft. Het doel van deze reis was het informeren van de deelnemers rondom de in Zweden gebruikte visserijtechnieken, netten en de ontwikkelingen rond het beperken van bijvangst in de Noorse kreeften visserij. Een van de besproken technieken om bijvangst de beperken in Zweden was het "Swedish grid" (Figuur 34). Dit betreft een sorteerrooster waarmee tijdens het vangstproces de gewenste Noorse Kreeften gescheiden worden van de overige (bij)vangst (Valentinsson \& Ulmestrand, 2007). Enkele deelnemers van de groepsreis hebben dit grid binnen NIKO2 getest in de Nederlandse Noorse kreeftenvisserij om een oplossing te vinden voor de ongewenste bijvangst van ondermaatse platvis.

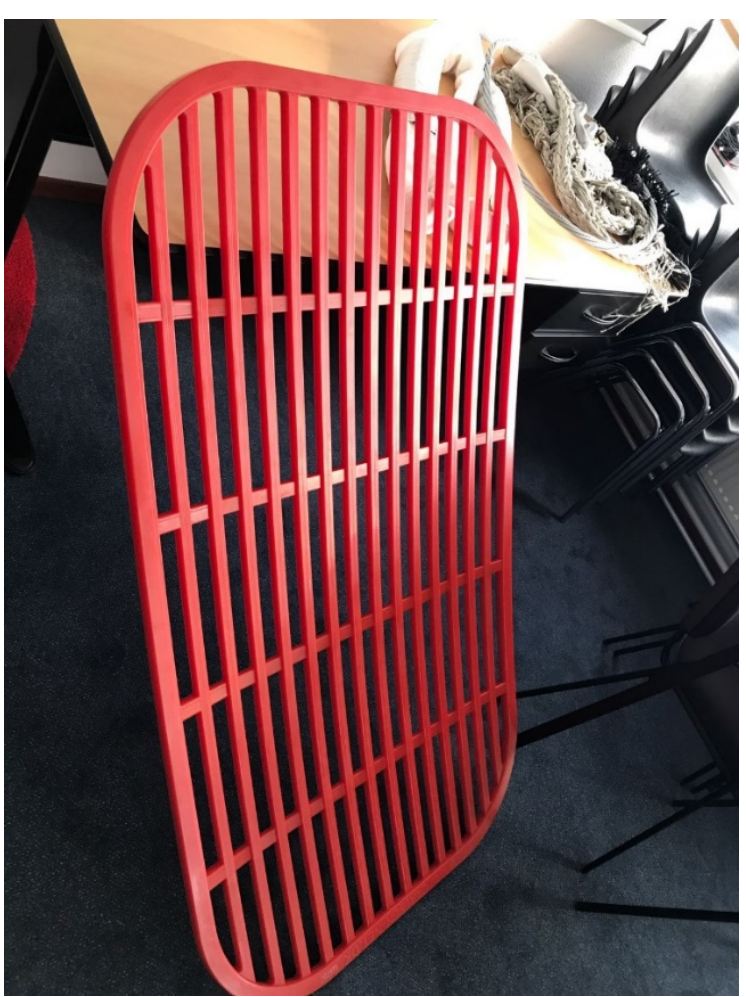

Figuur 34. Swedish grid met afmetingen: $150 \times 850 \times 2.5 \mathrm{~cm}$, gewicht $12 \mathrm{~kg}$, spijlafstand $35 \mathrm{~mm}$.

Het Swedish grid wordt in zweden gebruikt om selectief enkel Noorse kreeften te vangen zonder bijvangst van overige vissoorten. Het principe berust op het scheiden van de gemixte vangst door middel van een sorteerrooster. Dit rooster heeft spijlen die $35 \mathrm{~mm}$ uit elkaar staan, Noorse Kreeft kunnen het grid passeren door de openingen tussen de spijlen en de ongewenste (bij)vangst wordt door het rooster omhoog geleid naar een ontsnappings-gat in de bovenzijde van het net. 
De Nederlandse Noorse kreeftenvisserij is een gemixte visserij waarbij er naast Noorse Kreeft ook maatse vis gevangen en aangeland wordt, het gaat met name om schol, tarbot en griet. Deze marktwaardige visbijvangst kan een aanzienlijk deel van de vangst en besomming bedragen en is daarom belangrijk voor deze visserij.

Het Swedish grid zoals gebruikt in Zweden zorgt ervoor dat alle organismen die de openingen tussen de spijlen van het grid niet passeren ontsnappen. Omdat hiermee de waardevolle (bij)vangst van marktwaardige vis ontsnapt is dit geen oplossing voor de Nederlandse visserij. Het net dient daarom aangepast te worden, waarbij de vangst die niet door het grid gaat opgevangen wordt in een tweede kuil (in plaats van naar een ontsnappingsopening geleid wordt). Indien er in deze kuil een grotere maaswijdte gebruikt wordt $(120 \mathrm{~mm})$ dan kunnen de ondermaatse (plat)vissen ontsnappen. De kuil waarin de Noorse Kreeft opgevangen worden blijft $80 \mathrm{~mm}$. De verschillende aanpassingen en testen met de voor de Nederlandse visserij aangepaste "Swedish grid" zijn uitgewerkt binnen dit hoofdstuk. 


\subsubsection{Swedish grid praktijktesten}

De eerste testen met het grid uit Figuur 34 zijn in week 33 van 2017 aan boord van de WR 274 getest. In week 39 is dit grid ook getest door de WR 108. Er werd tijdens de testen alleen gekeken naar de scheiding van Noorse kreeft en vis van het net met Swedish grid. Uit de evaluatie van de praktijktesten bleek dat de werking van het grid positief was waarbij nagenoeg alle kreeft in de onderkuil aangetroffen werd en de vis in de bovenkuil (Figuur 35). Op deze visgronden was zeer beperkt (ondermaatse) schol aanwezig in de vangst, daarom kon er geen uitspraak gedaan worden over de effectiviteit van het scheiden van ondermaatse schol. Daarnaast bleek tijdens de testen dat de grids te groot en zwaar waren waardoor het lastig was om er aan boord mee te werken, ook vervormde het grid als het op de nettenrol gedraaid werd, de vervorming had een negatief effect op de werking.

$\mathrm{Na}$ de praktijktest is tijdens de evaluatie besloten dat er in vervolgproeven een kleiner verstevigd ontwerp van het Swedish grid gebruikt ging worden. Tevens moest het grid verder richting de kuil in het net geplaatst worden om vervorming op de nettenrol te voorkomen.

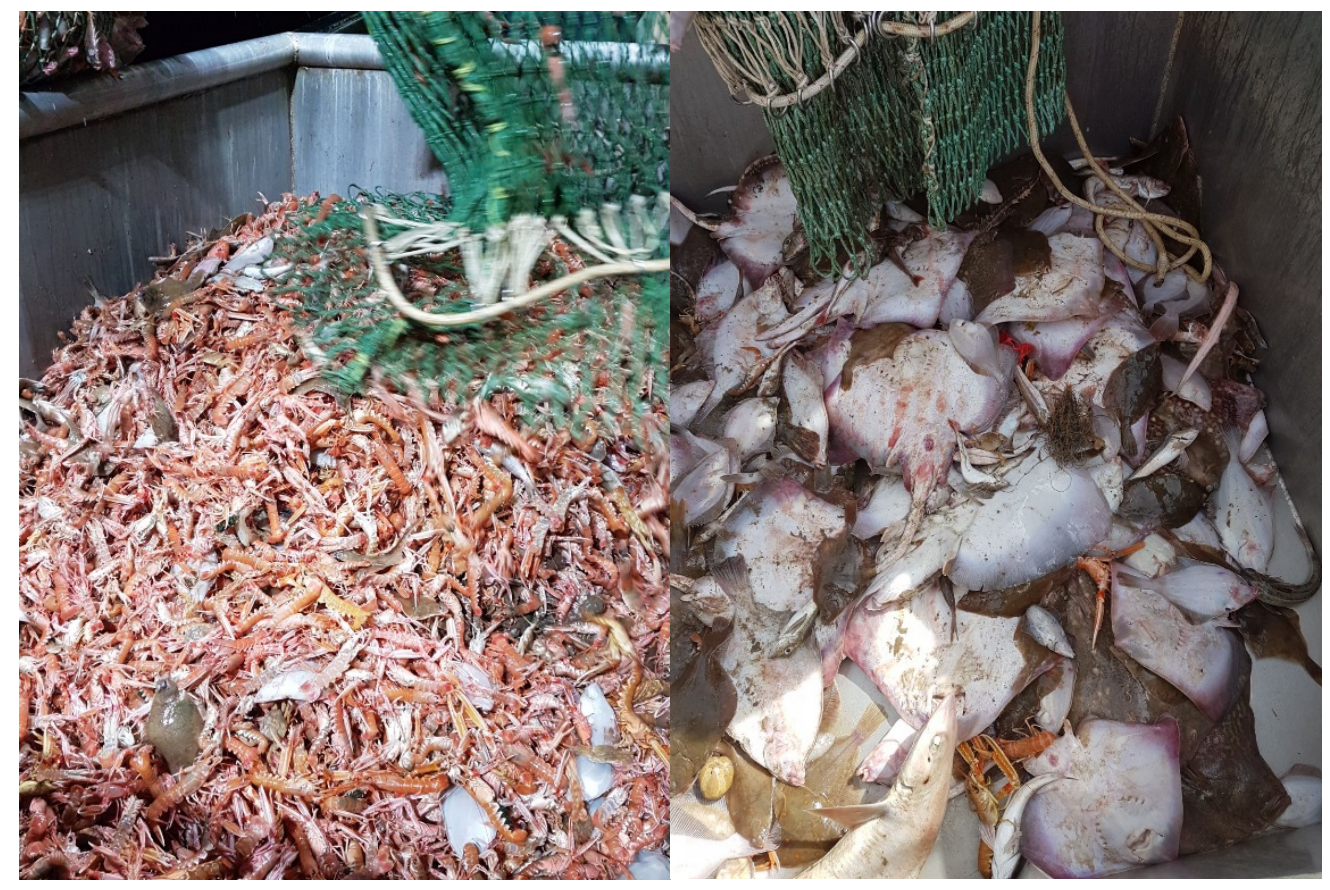

Figuur 35. Links de vangst van een nachttrek uit de onderkuil, rechts de vangst uit de (vis)bovenkuil. Beide kuilen hadden een vergelijkbare maaswijde. De scheiding van kreeft is deze trek uitstekend. Over effectiviteit van het grid op ondermaatse platvis kan gezien de geringe vangsten van platvis in beide kuilen weinig gezegd worden.

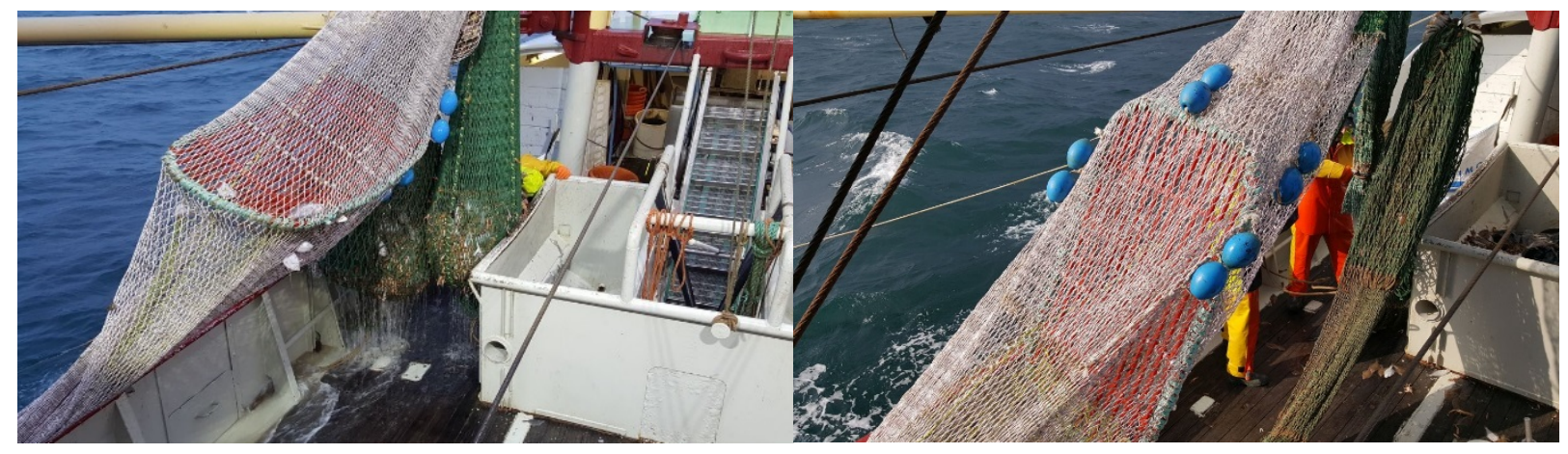

Figuur 36. Swedish grid zoals getest op de WR108 


\subsubsection{Praktijktesten verbeterde Swedish grid}

Met de aanbevelingen van de praktijktest in 2017 zijn er twee varianten van een verbeterd Swedish grid vervaarding door CIV Den Oever. Beide achternetten met grid zijn in week 28 van 2018 opnieuw getest op de WR274. Beide grids hebben een spijlafstand van $35 \mathrm{~mm}$, zijn $1250 \mathrm{~mm}$ hoog, $740 \mathrm{~mm}$ breed en gemaakt van PU (Figuur 37). Grid A is rood en onder een hoek van 52 graden in het net gezet en voor het grid voorzien van een trawl kite. De maaswijdte van de bovenkuil van dit achternet is $87,9 \mathrm{~mm}$ en $86,8 \mathrm{~mm}$ voor de onderkuil (omega gemeten, 10 mazen). Grid B is blauw en staat een hoek van 47 graden en is voorzien van enkele drijvers voor opwaartse kracht. Voor het grid is in de tunnel van het net een stuk geel netwerk aangebracht van 50mazen diep om de vangst naar de onderkant van het grid te dwingen. Hierdoor wordt het beschikbare oppervlak van het grid optimaal gebruikt voor selectie. De maaswijdte van de bovenkuil van dit achternet is $88,6 \mathrm{~mm}$ en $86,9 \mathrm{~mm}$ voor de onderkuil (Omega gemeten, 10 mazen). Tijdens de praktijkproef wordt naast de vangst ook gekeken of het grid zijn vorm behield als het op de nettenrol werd gedraaid.

De vangsten van beide netten werden samengevoegd, maar de onder en bovenkuil werden apart verwerkt en opgevangen, waarbij de vangst bemonsterd werd op basis van een discardmonster (paragraaf 0 ). Door het samenvoegen van de vangsten kan het verschil tussen beide ontwerpen niet vastgesteld worden.

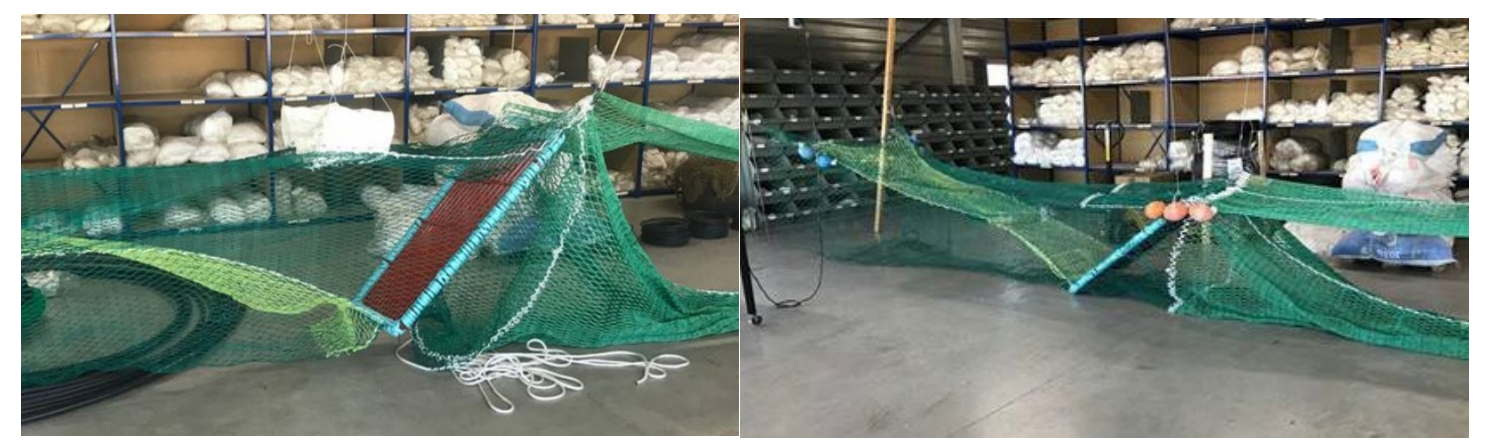

Figuur 37, links grid A onder een hoek van 52 graden met voor het grid een witte trawl kite aan de bovenzijde van het net bevestigd. Rechts, grid B onder een hoek van 47 graden met aan beide zijden 3 drijvers voor het stabiel houden van het grid tijdens het vissen. Beide achternetten zijn gemaakt door CIV Den Over.

\subsubsection{Resultaten self-sampling}

In week 28 heeft de WR274 13 trekken gedaan met het aangepaste Swedish grid A en B. Het reisverslag is te vinden in bijlage 7. Van deze trekken zijn 9 trekken bemonsterd, bij de overige trekken waren de weersomstandigheden dusdanig dat bemonstering niet mogelijk was. De eerste trek is niet bemonsterd en na de tweede trek bleek dat grid A op zijn kant lag tijdens het vissen. Daarop is de trawl kite vervangen voor drijvers. Na de $5^{e}$ trek is het grid $\mathrm{A}$ er af gehaald en is er verder gevist met grid $\mathrm{B}$. Hoe dit de bemonstering en resultaten beïnvloed heeft is onbekend. De bemonsterde vangsten zijn per trek weergegeven in (

Tabel 20 \& Tabel 21). Gemiddeld werd $28 \%$ van alle vangst in de bovenkuil en $72 \%$ in de onderkuil aangetroffen. Bij elke trek werd tussen de 1.1 tot $5.6 \mathrm{~kg}$ ongesorteerde Noorse kreeft in de bovenkuil gevonden en 34.4 tot $90.6 \mathrm{~kg}$ in de onderkuil, van de Noorse kreeft werd gemiddeld $4 \%$ in de bovenkuil gevonden. Opvallend is dat er in 5 van de 9 bemonsterde trekken exact $2.9 \%$ Noorse kreeft in de bovenkuil aangetroffen werd. Het grootste deel (83\%) van de marktwaardige schol werd in de bovenkuil aangetroffen, voor de ondermaatse schol was dit echter $42 \%$. Van de overige maatse vis (mul, kabeljauw, tarbot, griet wijting en schar) werd gemiddeld over alle trekken $80 \%$ in de bovenkuil aangetroffen, voor de ondermaatse vis (schar, wijting, pitvis, etc.) was dit gemiddeld $24 \%$. Voor de vangst van benthos werd gemiddeld $44 \%$ aangetroffen in de bovenkuil, hierbij is het opvallend dat op trekniveau de percentages in 8 van de 9 trekken op exact $43 \%$ uitkomt. 
Tabel 20. Middels self-sampling geregistreerde vangsten op de WR274 in de onder en bovenkuil van het aangepaste Swedish grid weergegeven in kilogram per trek. Per soort is er onderscheid gemaakt tussen maatse en ondermaatse exemplaren.

\begin{tabular}{|c|c|c|c|c|c|c|c|c|c|c|c|c|}
\hline \multirow[b]{2}{*}{ Trek } & \multicolumn{6}{|c|}{ |Bovenkuil (kg/trek) } & \multicolumn{6}{|c|}{ Onderkuil (kg/trek) } \\
\hline & $\begin{array}{c}\text { Noorse } \\
\text { Kreeft }\end{array}$ & Maats & $\begin{array}{l}\text { ol } \\
\text { Onder- } \\
\text { maats }\end{array}$ & $\begin{array}{r}\text { Over } \\
\text { Maats }\end{array}$ & $\begin{array}{l}\text { vis } \\
\text { Onder- } \\
\text { maats }\end{array}$ & Benthos & $\begin{array}{c}\begin{array}{c}\text { Noorse } \\
\text { Kreeft }\end{array} \\
\text { Maats }\end{array}$ & Maats & $\begin{array}{l}\text { Onder- } \\
\text { maats }\end{array}$ & $\begin{array}{r}\text { Ove } \\
\text { Maats }\end{array}$ & $\begin{array}{l}\text { e vis } \\
\text { Onder- } \\
\text { maats }\end{array}$ & Benthos \\
\hline 2 & 1.1 & 4.8 & 14.8 & 2.2 & 12.9 & 2.2 & 36.5 & 1.0 & 23.2 & 2.0 & 34.2 & 2.9 \\
\hline 3 & 2.4 & 9.9 & 33.0 & 4.2 & 21.6 & 4.5 & 74.5 & 1.0 & 43.8 & 1.0 & 34.2 & 5.9 \\
\hline 9 & 2.4 & 10.8 & 32.3 & 4.9 & 28.8 & 4.9 & 81.3 & 3.0 & 42.7 & 1.0 & 81.5 & 6.5 \\
\hline 10 & 5.6 & 9.7 & 32.3 & 8.3 & 22.6 & 4.4 & 69.7 & 4.0 & 50.8 & 1.0 & 67.9 & 5.8 \\
\hline 11 & 1.4 & 6.2 & 18.5 & 2.8 & 16.5 & 2.8 & 46.4 & 2.0 & 25.5 & 1.0 & 47.4 & 3.7 \\
\hline 12 & 2.0 & 8.8 & 25.9 & 4.0 & 23.4 & 4.0 & 66.2 & 3.0 & 38.1 & 1.0 & 66.0 & 5.3 \\
\hline 13 & 2.1 & 9.3 & 27.7 & 4.2 & 24.7 & 4.2 & 69.7 & 1.0 & 40.3 & 1.0 & 71.3 & 5.5 \\
\hline
\end{tabular}

Tabel 21. Percentages van de aangetroffen vangsten met het aangepaste Swedish grid. In de linker kolommen is het percentage van het net wat in de onder en bovenkuil ten opzichte van de totaalvangst van het net. Voor de overige waarden is per soort en categorie weergegeven welk percentage in de bovenkuil is aangetroffen van de gecombineerde vangst van de onder en bovenkuil.

\begin{tabular}{|c|c|c|c|c|c|c|c|c|c|}
\hline \multirow[b]{3}{*}{ Trek } & \multirow{2}{*}{\multicolumn{2}{|c|}{$\begin{array}{c}\text { percentage van } \\
\text { totale vangst }\end{array}$}} & \multicolumn{7}{|c|}{ Percentage van totale vangst per soort en maat aangetroffen in de bovenkuil } \\
\hline & & & \multirow[t]{2}{*}{$\begin{array}{c}\text { Noorse } \\
\text { Kreeft }\end{array}$} & \multirow{2}{*}{\multicolumn{2}{|c|}{$\begin{array}{c}\text { Schol maats } \\
\text { Onder- } \\
\text { Maats } \quad \text { maats }\end{array}$}} & \multirow{2}{*}{\multicolumn{2}{|c|}{$\begin{array}{c}\text { Overige vis } \\
\text { Onder- } \\
\text { Maats maats }\end{array}$}} & \multirow[t]{2}{*}{ Benthos } & \multirow[b]{2}{*}{ Opmerkingen } \\
\hline & $\begin{array}{l}\text { Boven } \\
\text { kuil }\end{array}$ & $\begin{array}{c}\text { Onder } \\
\text { kuil }\end{array}$ & & & & & & & \\
\hline 2 & 27.6 & 72.4 & 2.9 & 82.8 & 38.9 & 52.4 & 27.4 & 43.1 & \\
\hline 8 & 27.6 & 72.4 & 5.3 & 86.0 & 44.6 & 94.9 & 9.3 & 48.7 & Drijvers erbij \\
\hline 9 & 28.0 & 72.0 & 2.9 & 78.3 & 43.1 & 83.1 & 26.1 & 43.0 & \\
\hline 10 & 29.4 & 70.6 & 7.4 & 70.8 & 38.9 & 89.2 & 25.0 & 43.1 & Drijvers en geleidenetwerk eraf \\
\hline 11 & 27.7 & 72.3 & 2.9 & 75.6 & 42.0 & 73.7 & 25.8 & 43.1 & \\
\hline 12 & 27.5 & 72.5 & 2.9 & 74.6 & 40.5 & 80.0 & 26.2 & 43.0 & Grid op zijn kant? \\
\hline
\end{tabular}

\subsubsection{Conclusies en aanbevelingen self-sampling}

Uit de resultaten van de self-sampling blijkt dat Noorse kreeft effectief het grid kan passeren, gemiddeld werd $96 \%$ in de onderkuil gevonden. Van de gevangen ondermaatse schol werd gemiddeld $42 \%$ in de bovenkuil aangetroffen, hiervan kan een deel ontsnappen als er in de bovenkuil een 120mm maaswijdte wordt toegepast. Ondanks de aanpassingen aan het net gedurende de reis, en één trek waarbij het grid waarschijnlijk op zijn kant lag zijn de self-samplingsresultaten opvallend uniform. De aanbeveling dient daarom om aanvullende trekken te bemonsteren om een realistisch beeld te krijgen van de werking van het grid op verschillende visgronden en onder verschillende omstandigheden.

\subsubsection{Resultaten waarnemersreis met verbeterd Swedish grid}

In week 50 van 2018 (11/12/2018-14/12/2018) heeft er een onderzoeksreis plaatsgevonden op de WR274 waarbij de verbeterde versie van het Swedish grid getest is. Tijdens deze onderzoeksreis is een waarnemer van WMR en de tijdens ze self-sampling betrokken netmaker van CIV Den Oever mee geweest om detailmetingen te doen om de werking van het grid te onderzoeken. De WR274 vist met borden en vier netten (quad-rig) op Noorse Kreeft, het middelste net aan stuurboord was voorzien van een nieuw achternet met daarin het grid. De door het grid gescheiden vangstfracties zijn opgevangen in twee kuilen. Van beide kuilen zijn tijdens de reis 20 mazen gemeten met de OMEGA maaswijdtemeter, waarbij de bovenkuil een maaswijdte had van $84.5 \mathrm{~mm}$ (1.8 SD) en de onderkuil $83.5 \mathrm{~mm}$ (1.5 SD). Gedurende de reis waaide er een noordoostenwind met een kracht van 2 tot 7 bft. Er is gevist in het Botney gat (Figuur 38) en er zijn in totaal 7 trekken bemonsterd. 
De vangst is bemonsterd op basis van registratie van marktwaardige vis en een discardsample (paragraaf 2.1.2), hiervoor is de vangst van de onder- en bovenkuil apart opgevangen in tubs waarna het volume van de vangst bepaald is. Vervolgens is de maatse vis er door de bemanning uit gesorteerd en per kuil apart gehouden en gewogen. Van de discards werd per kuil gedurende het verwerkingsproces een sample genomen, dit sample werd gesorteerd op vissoorten, Noorse kreeft, benthos en debris. Van elke gesorteerde fractie is het gewicht genoteerd en voor de vissoorten en Noorse kreeft is de lengte van de carapax gemeten.

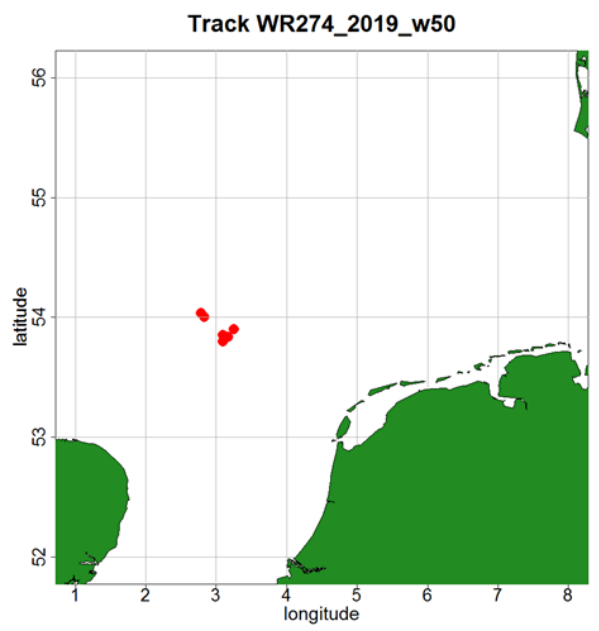

Figuur 38. Beviste locaties in het Botneygat gedurende de onderzoeksreis in week 502018 waarbij het swedish grid getest werd op de WR274.

Om de stand van het grid tijdens het vissen te monitoren was het grid voorzien van een STAR ODDI hellingshoeken, diepte en temperatuurlogger. Uit de gegevens van de datalogger bleek dat het grid bij de trekken 1, 5 en 6 tijdens het vissen rechtop stond onder een hoek van 40 tot 50 graden (0). Van trek 2 zijn geen meting in verband met uitlezen data, echter was aan de slijtage aan de touwen rond het grid te zien dat het grid waarschijnlijk gedraaid was. Uit de data blijkt dat gedurende trek 3, 4 en 7 het grid een deel van de trek 'omgevallen' was op zijn linker- of rechterkant. Opvallend is dat na enige tijd op zijn zij gevist te hebben het grid ook weer 'overeind' kwam in zijn gewenste positie (0).

Tabel 22 Resultaten waarnemersreis Swedish grid in vangst in gemiddelde vangst in kilo per uur voor de onder en bovenkuil. De vangsthoeveelheden zijn verzameld uit één net van de quad-rig optuiging waarin het Swedish grid gemaakt was. Indien de vangst niet door de spijlopeningen van het grid ging deze opgevangen is in de bovenkuil.

\begin{tabular}{|c|c|c|c|c|c|c|}
\hline Soort & & Onderkuil & & Bovenkuil & & $\begin{array}{c}\% \text { in } \\
\text { bovenkuil }\end{array}$ \\
\hline & $\begin{array}{l}\text { Landings/ } \\
\text { discards }\end{array}$ & $\mathrm{kg} / \mathrm{uur}$ & SD & $\mathrm{kg} / \mathrm{uur}$ & SD & \\
\hline Noorse Kreeft & L & 2.79 & 1.59 & 0.19 & 0.20 & $6 \%$ \\
\hline$<\sim 32 \mathrm{~mm} \mathrm{CL}$ & $\mathrm{D}$ & 1.58 & 1.47 & 0.16 & 0.17 & $9 \%$ \\
\hline Schol & $\mathrm{L}$ & 1.31 & 0.65 & 4.66 & 1.82 & $78 \%$ \\
\hline$<26 \mathrm{~cm}$ & D & 4.27 & 1.99 & 6.60 & 2.07 & $61 \%$ \\
\hline Tong & $\mathrm{L}$ & 0.15 & 0.20 & 0.20 & 0.14 & $57 \%$ \\
\hline$<24 \mathrm{~cm}$ & D & - & - & - & - & - \\
\hline Schar & $\mathrm{L}$ & 0.06 & 0.03 & 0.07 & 0.05 & $51 \%$ \\
\hline$<\sim 30 \mathrm{~cm}$ & D & 0.62 & 0.21 & 0.31 & 0.18 & $33 \%$ \\
\hline Wijting & $\mathrm{L}$ & 0.31 & 0.32 & 0.53 & 0.29 & $63 \%$ \\
\hline$<26 \mathrm{~cm}$ & $\mathrm{D}$ & 4.16 & 1.47 & 1.34 & 0.63 & $24 \%$ \\
\hline \multirow[t]{2}{*}{ Overige vis } & $\mathrm{L}$ & 0.17 & 0.15 & 1.46 & 1.16 & $90 \%$ \\
\hline & D & 0.80 & 0.64 & 4.08 & 5.01 & $84 \%$ \\
\hline Benthos & $\mathrm{D}$ & 3.23 & 2.12 & 0.67 & 0.47 & $17 \%$ \\
\hline
\end{tabular}


Uit de vangstanalyse van het testnet kwam van de marktwaardige Noorse Kreeft gemiddeld $0.19 \mathrm{~kg} / \mathrm{u}(6 \%)$ in de bovenkuil terecht. Voor de marktwaardige vis betrof dit $4.66 \mathrm{~kg} / \mathrm{u}(78 \%)$ voor schol, $0.2 \mathrm{~kg} / \mathrm{u}(57 \%)$ voor tong, en $0.53 \mathrm{~kg} / \mathrm{u}(63 \%)$ voor wijting. Overige vis bestaat uit rode- en grauwe poon, gevlekte- en stekelrog, honds- en gladde gevlekte haai, tarbot, griet en kabeljauw. Van de overige vis werden van zowel de aanlandingen als discards het grootste deel (90 \& 84\%) in de bovenkuil aangetroffen.

Van de niet markwaardige Noorse kreeft (discards) werd gemiddeld $0.16 \mathrm{~kg} / \mathrm{u}(9 \%)$ in de bovenkuil aangetroffen. Voor de ondermaatse vis was dit $6.6 \mathrm{~kg} / \mathrm{u}(61 \%)$ voor schol, $0.31 \mathrm{~kg} / \mathrm{u}(33 \%)$ voor schar en $1.34 \mathrm{~kg} / \mathrm{u}(24 \%)$ voor wijting. Benthos werd meestal in de onderkuil aangetroffen met $3.23 \mathrm{~kg} / \mathrm{u}(83 \%)$.

De resultaten laten zien dat met het toepassen van het Swedish grid een aanzienlijk deel va de ondermaatse schol $(61 \%)$ in de bovenkuil van het net terecht komt. Voor het naar boven geleiden van ondermaatse wijting (24\%) en schar (33\%) was dit het grid minder effectief.
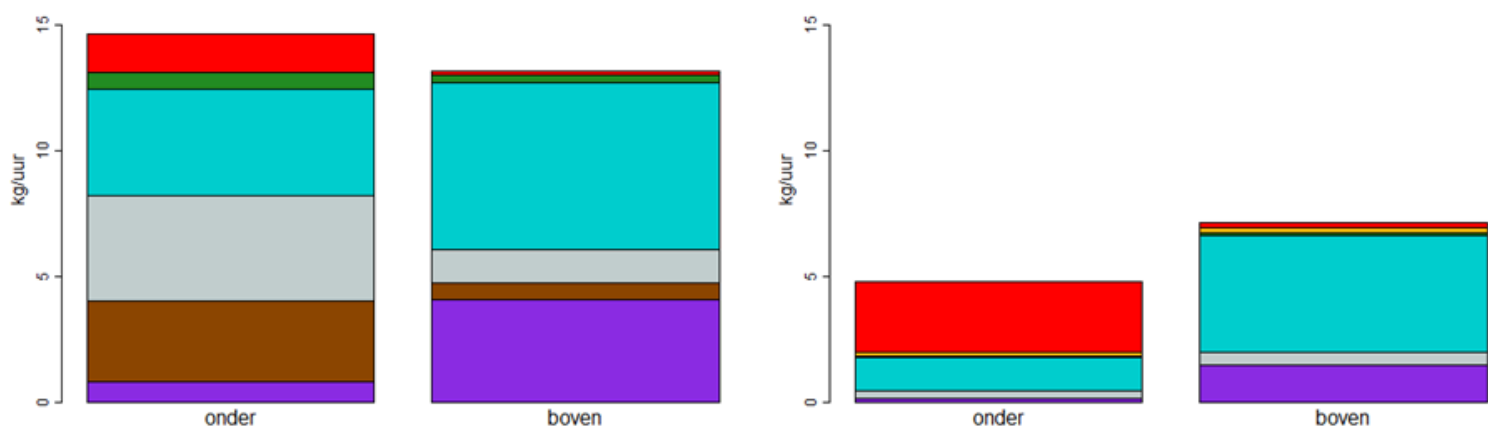

믈 $\begin{aligned} & \text { overige } \\ & \text { benthos }\end{aligned}$ 
Pleuronectes platessa

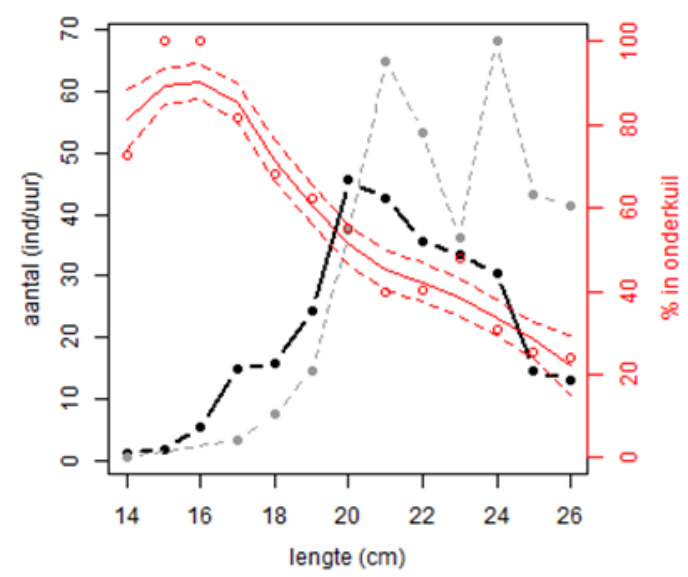

- onderkuil $\square$ bovenkuil
Nephrops norvegicus

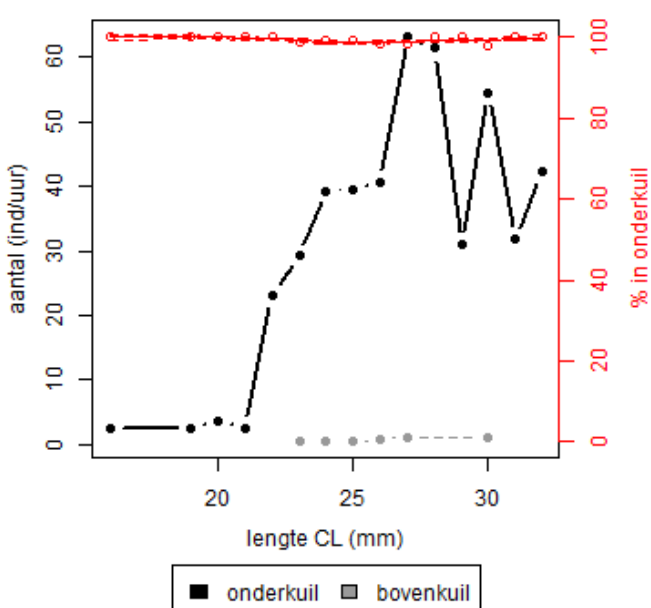

Limanda limanda

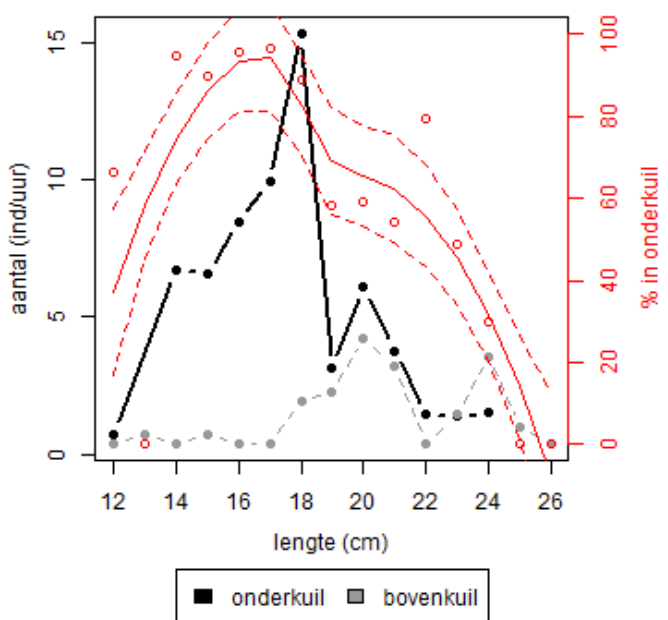

Merlangius merlangus

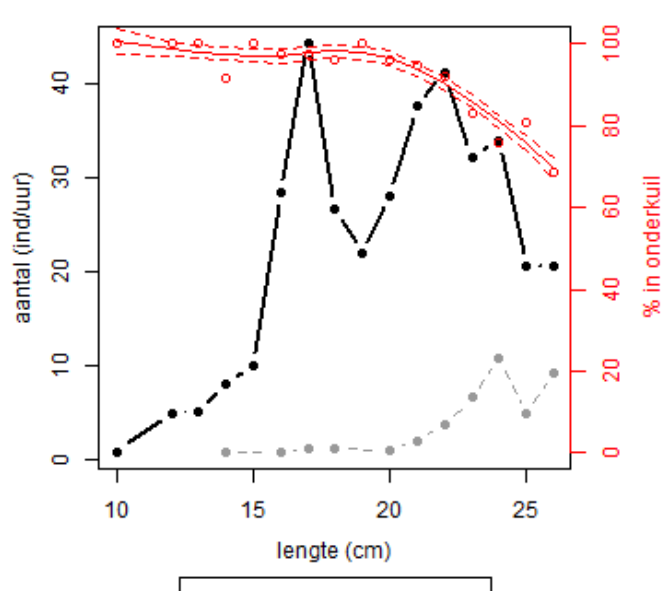

onderkuil $\square$ bovenkuil

Figuur 40. Gemiddelde lengte frequentie verdeling van gevangen discards in aantallen per uur gevangen in de bovenkuil (grijs) en onderkuil (zwart). De rode lijn geeft het percentage van de totale vangst van die lengteklasse (onder + boven) die is aangetroffen in de onderkuil

Gedurende de onderzoeksreis zijn de lengtes gemeten van de ondermaatse- of niet marktwaardige individuen welke gevangen zijn in de onder en bovenkuil. De resultaten voor schol, Noorse kreeft, wijting en schar zijn weergegeven in Figuur 40. Opvallend is dat van de schol kleiner dan $19 \mathrm{~cm}$ de meerderheid in de onderkuil gevangen wordt, deze kleine schol gaat dus door de spijlen van het grid. Van 10 tot $26 \mathrm{~cm}$ is er een trend zichtbaar waarbij de grotere individuen niet tussen de spijlen door gaan en in de bovenkuil aangetroffen worden, waarbij $22 \%$ van de schollen van $26 \mathrm{~cm}$ in de onderkuil aangetroffen wordt. Niet marktwaardige Noorse kreeft tot $32 \mathrm{~mm}$ carapax lengte werd van elke lengte meer dan $95 \%$ in de onderkuil aangetroffen. Voor schar lag dit anders, van de scharren kleiner dan $19 \mathrm{~cm}$ werd het grootste deel in de onderkuil aangetroffen, waarbij er bij de grotere scharren $(20-26 \mathrm{~cm})$ het grootste deel in de bovenkuil gevangen werd. Van de ondermaatse wijting werd van alle lengteklassen 70-95\% in de onderkuil gevangen. 


\subsubsection{Conclusie en discussie}

Indien de bovenkuil in een commerciële situatie voorzien wordt van een grotere maaswijde (120mm) kan een deel van de ondermaatse vis ontsnappen, waarbij maximaal $61 \%$ van de ondermaatse schol, $24 \%$ ondermaatse wijting en $33 \%$ schar kan ontsnappen. Voor alle soorten betreft het voornamelijk de grotere exemplaren van de ondermaatse vis. Echter, ontsnapt meestal niet alle ondermaatse vis, deze percentages geven daarom een indicatie van de maximale potentie onder deze omstandigheden.

Uit de data van de hellingshoeken logger die op het grid bevestigd was bleek dat de positie van het grid in 3 van de 7 trekken de gehele trek de juiste positie heeft gehouden. Indien er naar de resultaten van deze individuele trekken gekeken wordt $(0)$ is het mogelijk dat het grid effectiever kan werken dan in het gemiddelde van deze 7 trekken naar voor komt. Echter, dient het grid dan wel verder verbeterd te worden zodat het stabieler in het net staat tijdens het vissen. 


\section{Flyshoot}

De flyshootvisserij is veruit de minst bestudeerde visserijtak in onderhavig onderzoek. Voor een goed begrip van de techniek is meer fundamenteel onderzoek noodzakelijk. Met name de interactie tussen de verschillende vistuigonderdelen en de verschillende vissoorten is nog vaak onbekend. Om netaanpassingen voor een betere selectiviteit te kunnen ontwerpen is eerst de observatie van het visgedrag t.o.v. de zegentouwen, de vlerken, de bovenpees, de rubberpees en de andere netonderdelen noodzakelijk. Daarom wordt aanbevolen om meer onderwateropnames te maken. In het verleden werden binnen de kenniskringen flyshoot door het ILVO onderwateropnames gemaakt. Deze beelden kunnen reeds gebruikt worden, maar zijn nog onvoldoende. Specifieke opnamen zijn gewenst, waarbij in samenspraak met de vissers de bovenstaande vragen over visgedrag ten opzichte van de diverse netonderdelen beantwoord kunnen worden. Het is verstandig om exclusieve tijd uit te trekken voor het maken van de onderwateropname, waarbij er geen tijdsdruk is omwille van eventueel vangstverlies. Ook de keuze van een bestek met goede zichtbaarheid is uitermate van belang.

Het project NIKO II had als doelstelling om de selectiviteit in de kottervisserijen te verhogen, netinnovaties te kwantificeren en de samenwerking met visserij coöperaties en nettenmakers te verbeteren om op die manier de uitdagingen van de aanlandingsplicht beter het hoofd te bieden. De focus van de module Flyshoot lag daarbij vooral op de vangst van wijting, aangezien dat deze soort regelmatig gevangen wordt maar in tegenstelling tot de rest van de vangst een (beperkt) quota kent.

Aangezien het een vrij nieuwe visserijtechniek betreft waarvan nog niet zoveel geweten is, werd enerzijds een literatuuronderzoek gedaan en anderzijds ingezet op het maken van onderwatercamerabeelden om zoveel mogelijk kennis te vergaren met betrekking tot het gedrag van wijting (en andere doelsoorten) en het verloop van het vangstproces. Deze info kon dan later gebruikt worden voor het testen en evalueren van enkele netaanpassingen op het gedrag en de ontsnapping van wijting.

Dit hoofdstuk bevat enkel de meest interessante zaken. De overige info werd gebundeld in 3 bijlagen: overzicht literatuur (0), observaties onderwaterbeelden $(0)$ en reisverslagen $(0)$.

\subsection{Literatuuronderzoek}

De samenvattingen per publicatie worden gegeven in 0 .

\subsubsection{Conclusies}

- $\quad$ r is weinig kennis voorhanden over hoe wijting zich gedraagt in een flyshootnet en/of hoe dit gedrag zich verhoudt tot die van andere soorten die niet mogen ontsnappen zoals mul, makreel of inktvissoorten.

- Wijting vertoont geen duikend vluchtgedrag, maar zal ofwel omhoog ofwel zijdelings trachten te ontsnappen

- Het grootste deel van de wijting (schelvis en koolvis) komt hoger dan $1 \mathrm{~m}$ de staart van het net binnen, terwijl kabeljauw en platvis meestal in de onderste $20 \mathrm{~cm}$ van het net terug te vinden zijn en zelden hoger dan $1(.5) \mathrm{m}$.

- Wijting ontsnapt (relatief) gemakkelijk door de mazen van het net als zijn grootte het toelaat en er contact gemaakt wordt. Dit contact wordt gestimuleerd indien er mechanische of visuele elementen zijn die de vis stimuleren om zijn zwemgedrag aan te passen. Vierkante mazen van $80 \mathrm{~mm}$ zijn perfect voor lozen van ondermaatse wijting. Grotere mazen zorgen enkel voor groter verlies van commerciële vis.

- Een paneel met vierkante mazen in de rug van het net wordt effectiever naarmate het zich meer naar achteren bevindt. 


\subsubsection{Hypothetische netaanpassingen op basis van literatuur}

\subsubsection{Scheiding op basis van verschil in gedrag}

Indien op de camerabeelden een verschil wordt gezien in reactie van wijting op visuele of fysieke stimuli in vergelijking met makreel, mul of inktvis dan zouden deze verschillen gebruikt kunnen worden om het gedrag van de vissen te beïnvloeden zodat een verbeterde selectiviteit met minimaal vangstverlies van marktwaardige vis kan gerealiseerd worden.

Meest voor de hand liggende optie is om gebruik te maken van een ontsnappingspaneel met vierkante 80 $\mathrm{mm}$ mazen in de rug aangezien de literatuur aangeeft dat ondermaatse wijting daar door ontsnapt. De testen zouden dan het beste kunnen focussen op (i) vaststellen hoe groot de ontsnapping van (ondermaatse) wijting is, (ii) kijken of die ontsnapping kan verhoogd worden door gebruik te maken van extra stimuli en (iii) bepalen hoeveel andere marktwaardige vis verloren gaat.

\subsubsection{Scheiding op basis van verschil in vangsttijdstip}

Tijdens de bijeenkomst (Stellendam, 28/04/2017) werd er door sommige vissers en reders geopperd dat wijting sneller in het net binnenkomt in vergelijking met bijvoorbeeld makreel. Ofschoon een volledige scheiding tussen beide soorten onmogelijk lijkt omwille van hun gelijkaardige vorm en positie in het net, zou er mogelijk dus wel een deel van de wijting geloosd kunnen worden in het begin van het vangstproces als er nog geen andere vis bovenaan in de staart van het net is.

Een mogelijkheid is om een paneel met grote vierkante mazen aan te brengen in de rug aan het begin van de staart om via deze weg wijting te lozen. Zonder stimuli gaat het gros van de vis er echter onderdoor. Een mogelijkheid is om gebruik te maken van een oplopend stuk net of oplopend touwwerk (al dan niet met boeien), maar dit zou ook tot aanzienlijke ongewenste verliezen van andere doelsoorten leiden. Tijdens het overlegmoment werd aangegeven dat wijting vroeger dan de andere soorten in het net binnenkomt en daarom is het mogelijk de vis in de fase van de vangst nog te proberen te lozen. Dit zou bekomen kunnen worden door touwen met vlotters die enkel aan het onderpaneel bevestigd worden en die in het begin van het binnenhalen, bij lage sleepsnelheden, stijl omhoog staan en zo de wijting afleiden naar het paneel. In het ideale geval worden deze strengen met vlotters later in het proces, bij hogere watersnelheden door het net, platgeduwd waardoor er dan geen/weinig verlies meer zou optreden.

\subsection{Mogelijke netaanpassingen}

\subsubsection{Overzicht}

Op basis van de literatuur leken de volgende netaanpassingen of materialen het meest voor de hand liggend om te testen in een flyshootnet en de werking ervan visueel te evalueren:

- Groot paneel met vierkante mazen $(80 \mathrm{~mm})$ in de rug van het net om te kijken welke soorten er wanneer door ontsnappen, cfr paneel verplicht in de Noordzee.

- Op een helft (L/R) van het paneel met $80 \mathrm{~mm}$ vierkante mazen kunnen mogelijks korte stukjes touw $(2 \mathrm{~cm})$ bevestigd worden op dwarse benen die bij stroming in de maasopening fladderen zodat de maas visueel gesloten lijkt, maar de vis bij contact er toch doorheen gaat.

(Er van uitgaande dat makreel meer visueel beslist en wijting meer op contact)

- Ontsnappingspaneel boven rijging in zijkant van staart, al dan niet over volledige rug.

- Paneel in opvallend wit garen of donker garen.

- Gekleurde of witte lichtjes, al dan niet knipperend.

- Touwen met veel kleine vlotters (loodgecompenseerd) of witte touwen met slechts enkele grote vlotters op het einde (loodgecompenseerd) om vis te 'leiden'.

- Reep netwerk dat met behulp van 2 touwtjes van ca $20 \mathrm{~cm}$ (zodat o.a. platvis er nog vlot onder kan) aan buik is bevestigd en bovenaan omhoog gehouden wordt door vlotters.

- Gebruik van licht/lampen. 


\subsubsection{Beschrijving getest ontsnappingspaneel}

Er werd gebruik gemaakt van een ontsnappingspaneel zoals het ook gebruikt wordt door Flyshooters in de Noordzee (Figuur 41). Het paneel was $1.5 \mathrm{~m}$ breed en in totaal $3.4 \mathrm{~m}$ lang, bestaande uit vierkante mazen van ongeveer 4.5 op $4.5 \mathrm{~cm}$ (gestrekte maasopening van $87.8 \pm 2.3 \mathrm{~mm}$ ). Het paneel zat $10 \mathrm{~m}$ voor de aanzet van de staart.

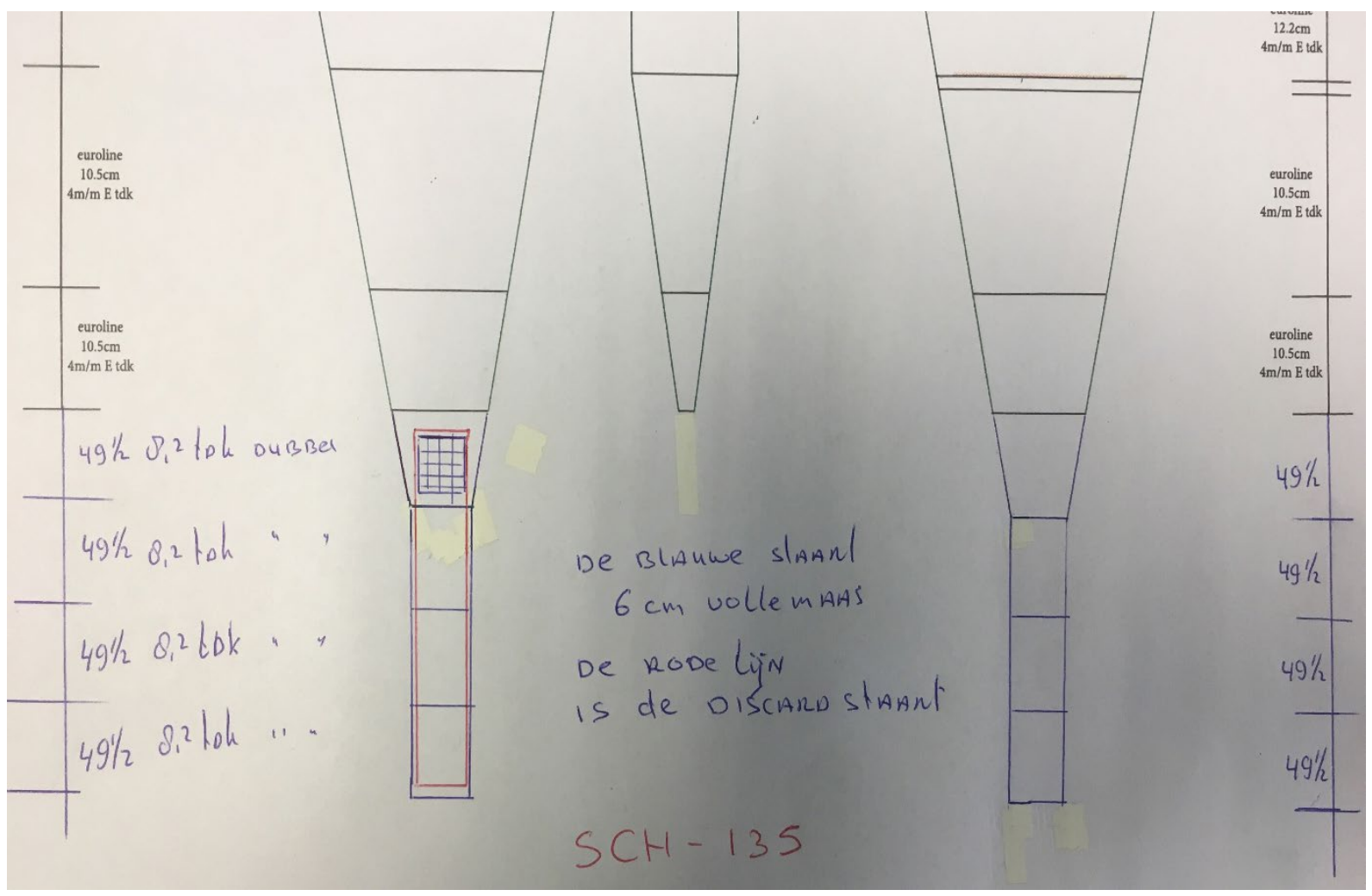

Figuur 41. Nettekening van het gebruikte experimentele net met daarop de locatie van het ontsnappingspaneel en de afmetingen van de overkuil.

Om een goed zicht te krijgen op de ontsnapping door het paneel werd er door Coöperatie Westvoorn ook een overkuil over het paneel gezet met een volle maas van $6 \mathrm{~cm}$ (maasopening van $55.2 \pm 1.0 \mathrm{~mm}$ ). Deze werden voorzien van drijvende blaasjes/vlotters om de overkuil mooi open te houden en te vermijden dat hij het paneel zou gaan afdekken (Figuur 42).

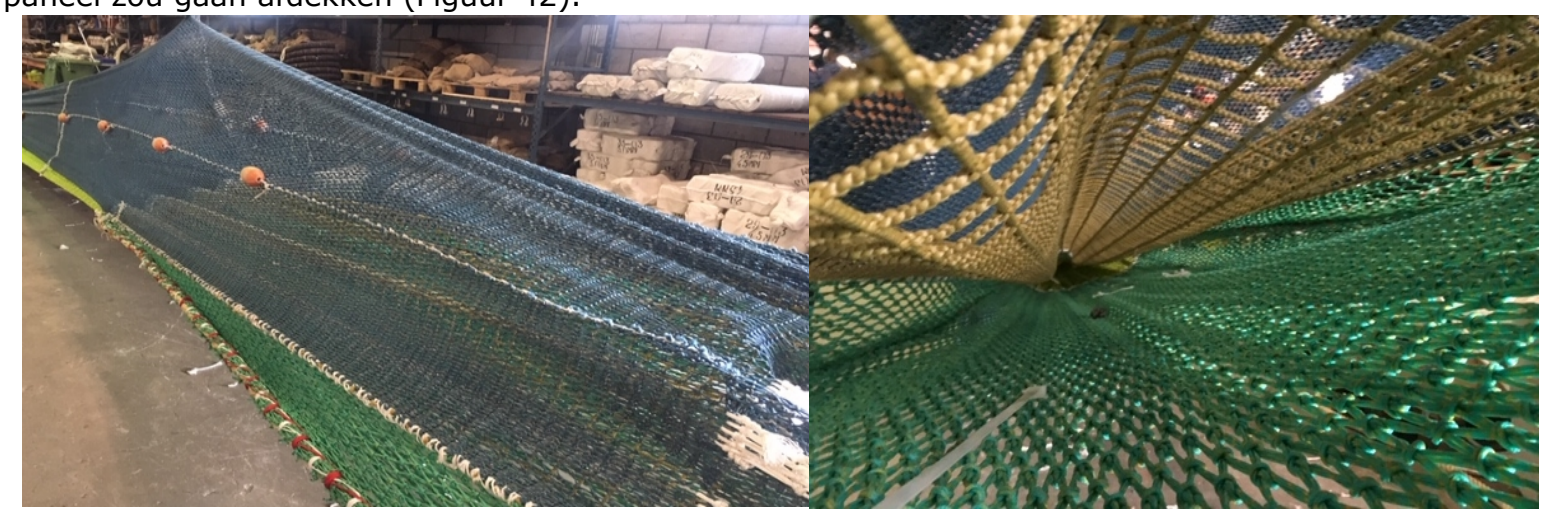

Figuur 42: Twee foto's waarop de overkuil in blauw netmateriaal met oranje drijvende blaasjes te zien is van de buitenkant (links) en van binnenuit waarbij men door de witte vierkante mazen van het ontsnappingspaneel kijkt (rechts). 


\subsection{Onderwateropnames}

\subsubsection{Doelstelling}

De voornaamste vragen bij aanvang van het project waren

- Welke vissoort komt wanneer het net binnen?

- Waar bevindt elke soort zich in de staart van het net waar eventuele scheiding kan gebeuren en hoe reageren ze op de toenemende snelheid tijdens het vangstproces?

- Welke soorten (en grootte) ontsnapt er precies door een ontsnappingspaneel met vierkante mazen in de rug van het net?

- Welke impact hebben mechanische en/of visuele stimuli ter hoogte van het ontsnappingspaneel op ontsnapping(gedrag)?

\subsubsection{Methode}

Gezien de grote afstand tussen het schip en het net werd er geopteerd om te filmen met go pro's die met behulp van frames in of op het net bevestigd werden door een technisch medewerker van het ILVO.

\subsubsection{Resultaten}

Ruwe beelden kunnen opgevraagd worden bij het ILVO. De beste fragmenten zijn eveneens te verkrijgen bij Jaczon of Coöperatie Westvoorn. Een gedetailleerde beschrijving per reis en per fragment is terug te vinden in 0 .

\subsubsection{Reis 1 - maart 2017: net zonder aanpassingen ( 3 bruikbare trekken)}

- Vangst schuift terug van kuil naar staart wanneer er gestopt wordt met halen om uit te pikken.

- Eerst platvis in net (onderaan), daarna de rondvis (hoger in staart). Telkens in wisselende hoeveelheden qua aantal.

- In sommige trekken opent de staart pas laat en komt de vis niet geleidelijk door de staart, maar als 1 grote bal van verschillende soorten.

\subsubsection{Reis 2 - april 2018: $80 \mathrm{~mm}$ ontsnappingspaneel in rug en extra stimuli ( 9 bruikbare trekken)}

Welke vissoort komt wanneer door de staart?

- Net recht en vullend vanaf 25-30 min na te water lating

- Platvis komt binnen vanaf laatste 30-40 min van de trek

- Wijting komt het net binnen vanaf laatste 15-30 minuten van trek

- Haring komt pas net binnen in laatste 10-15min van trek

- Vaak komt eerste rondvis als een 'bal': ze stroppen ergens op en het net opent pas later.

- Sommige trekken ging de vis over het net, andere trekken waren onderpees en spie opgerold: de netopening vist niet elke trek stabiel en betrouwbaar.

Waar bevindt elke soort zich in de staart van het net waar eventuele scheiding kan gebeuren?

- Haring gegroepeerd, soms enkel bovenaan, soms zijkant. Geobserveerde ontsnapping bijna altijd zijdelings.

- Wijting die ergens tegen tikt (bv waar paneel samengezet is) maakt makkelijker beweging omhoog. Paneel met meer ribben zou dus efficiënter kunnen werken. Een 'dansend' paneel zal waarschijnlijk ook tot meer ontsnapping leiden.

- Platvis schijft vlot door naar kuil, rondvis probeert zijn positie t.o.v. het net constant te houden zolang de snelheid dat toelaat.

- Hondshaai, inktvis, poon, ... ook afzonderlijk. Locatie lijkt meer variabel.

- Regelmatige blijkt vis gemengd als een bal richting kuil te schuiven omdat de staart niet tijdig mooi open ging staan (afhankelijk van tij?). Dit bemoeilijkt uiteraard selectie d.m.v. paneel doordat er weinig zwemruimte en tijd is op het moment dat ze zich onder het paneel bevinden. 
Hoe reageren ze op de toenemende snelheid tijdens het vangstproces?

- Platvis, poon, ... vechten zo lang ze kunnen voor en in de mond van het net, maar eens in het net schuiven ze vlot door richting kuil (reeds uitgeput).

- Rondvis: Geen duidelijke beelden van gedrag in netopening, maar eens in het net/de staart houden ze zo lang mogelijk gelijke tred met het hen omringend netmateriaal. Eens snelheid te hoog wordt schuiven ze noodgedwongen door naar de kuil.

- Wijting in combinatie met paneel: zonder overkuil gaat een ontsnapte vis onmiddellijk zijn weg naar boven voortzetten en drijft hij snel af naar achteren. Met overkuil gaat de vis opnieuw proberen gelijke tred te houden t.o.v. netmateriaal rond hem.

Welke soorten (en grootte) ontsnapt er precies door een ontsnappingspaneel met vierkante mazen in de rug van het net?

- Hoe strakker net openstaat, hoe minder ontsnapping. Hoe meer ribbels en plooien, hoe makkelijker ontsnapping optreedt.

- In aanwezigheid van licht lijken ze schichtiger te bewegen.

- Aanwezigheid van (lood)touwtjes lijkt geen invloed te hebben.

- Rudimentaire vangstanalyse van trek 3 toont aan dat verlies van commerciële vis door paneel in rug verwaarloosbaar is: 5 maatse wijtingen en een inktvisje op een zak van 200-300 kg geloosde vis.

Welke impact hebben mechanische en/of visuele stimuli ter hoogte van het ontsnappingspaneel op ontsnapping(sgedrag)?

- Rode touwen voor het paneel \& Witte loodtouwtjes op het einde van het paneel:

- Vissen maken zo min mogelijk contact, maar zien het niet als een bedreiging en zwemmen er rond, voor, achter naargelang ze dat nodig achten.

- Aanwezigheid van (lood)touwtjes lijkt het gedrag van wijting of haring weinig te beïnvloeden en gaf geen aanleiding tot verhoogde ontsnapping door het paneel.

$\Rightarrow$ Verschil met literatuur mogelijk te verklaren doordat deze touwtjes dun waren en traag of niet bewogen, vs dikke koorden met blaasjes die harder trilden en door het water bewogen.

$\Rightarrow$ Geen meerwaarde

- Lampen

- Vis lijkt zenuwachtiger te reageren met lampen (of door laag net?) en maakt meer 'burst' bewegingen, wat kans op ontsnapping zou moeten vergroten.

$\Rightarrow$ Om verbeterde ontsnapping vast te stellen zouden we (i) de vangstanalyse van trekken met lichtjes moeten vergelijken met trekken zonder (data van januari 2019) of (ii) moeten een vangstvergelijking doen door te werken met een broeknet.

Het nadeel van een broeknet is dat verwerking van de vangst ook gescheiden zou moeten verlopen en het net dus niet gevierd zou kunnen worden vooraleer de vangst uit de ene kuil volledig verwerkt is en de hopper opnieuw leeg is.

\subsubsection{Derde reis (januari 2019): net met ontsnappingspaneel (rug) ( 3 half bruikbare} trekken)

- Geen zicht op werking op bodem wegens te donker.

- Voldoende ruimte tussen overkuil en paneel: geen belemmering van ontsnapping

- Paneel meestal gegolfd wat ontsnapping vermoedelijk bevordert.

- Overkuil staat telkens mooi horizontaal en in verlengde van de staart.

$\Rightarrow$ Er zijn geen aanwijzingen om aan te nemen dat de overkuil de ontsnapping door het paneel belemmerd zou hebben.

\subsubsection{Conclusie}

Een ontsnappingspaneel (vierkante mazen van $80 \mathrm{~mm}$ ) lijkt veelbelovend om ondermaatse wijting te laten ontsnappen, zeker omdat het verlies van andere commerciële soorten klein lijkt. Hoe meer het paneel gegolfd lag of bewoog, hoe makkelijker wijting (zijdelings) leek te ontsnappen. Platvis en poon volgen eerder de buik, inktvis stroomt gewoon onder het paneel door en soorten als haring die in school zwemmen blijven bij elkaar 
en ontwijken als school het net, ongeacht of ze er door kunnen of niet. Vangstanalyse d.m.v. overkuil is echter nodig om het verlies te kwantificeren en verdere testen in periodes met mul zijn aangewezen om een mogelijk verlies van deze soort vast te stellen.

De aanwezigheid van de overkuil tijdens de uitgevoerde experimenten leek de ontsnapping ook niet te belemmeren. Er was voldoende ruimte tussen overkuil en paneel en de overkuil hing mooi in verlengde en horizontaal boven de staart en kuil waardoor de doorstroming naar achter toe niet belemmerd zou mogen geweest zijn. De resultaten van de vangstanalyse zouden dus representatief moeten zijn voor de situatie zonder overkuil.

\subsection{Vangstanalyse ontsnappingspaneel}

\subsubsection{Inleiding}

De camerabeelden van april 2018 toonden aan dat vooral wijting door het paneel ontsnapte. Bepaalde commercieel belangrijke soorten zoals mul werden toen echter niet gevangen en bovendien bleek het niet mogelijk om op basis van de camerabeelden de hoeveelheid ontsnapping te gaan kwantificeren. Daarom werd besloten om te werken met een kleinmazige $55 \mathrm{~mm}$ overkuil over het $90 \mathrm{~mm}$ paneel zodat alle vis die er normaal door zou ontsnappen, weerhouden zou blijven. Dit laat een vangstanalyse toe waarbij de vangsten in de overkuil kunnen geanalyseerd en vergeleken worden met deze in de normale $80 \mathrm{~mm}$ kuil. Het laat bovendien toe om relatief nauwkeurig te bepalen welk aandeel van de ondermaatse vis, in het bijzonder wijting, en commerciële vis zoals mul ontsnapt doorheen het paneel.

\subsubsection{Resultaten self-sampling}

Teneinde een eerste inschatting te krijgen van de hoeveelheid vis die daadwerkelijk door het paneel ontsnapt en de rentabiliteit van een dergelijk paneel in 'Het kanaal' te verzekeren, werd beslist om voorafgaand aan de waarnemersreis al aan self-sampling te doen. Hiervoor werd de bemanning gevraagd om een inschatting te maken van enerzijds het totale vangstgewicht van de kuil en de overkuil over het paneel, en anderzijds de gewichten van commerciële vis in beide kuilen op basis van de data in het logboek. Een overzicht van de verzamelde gegevens wordt gegeven in Tabel 23.

Tabel 23. Een samenvatting van de geschatte vangstgewichten in de kuil ('kuil') en overkuil over het paneel ('paneel') op de SCH135 over 15 trekken in week 43,44 en 51 van 2018. 'SOM' geeft het totaal weer over de 15 trekken, 'GEMIDDELDE' het gemiddeld geschat vangstgewicht van die fractie per trek waarin de fractie aanwezig was. 'Totaal' geeft het totaal geschat gewicht van de vangst weer.

\begin{tabular}{|c|c|c|c|c|c|c|}
\hline & & \multicolumn{2}{|c|}{ Som (kg) } & \multicolumn{2}{|c|}{ Gemiddeld (kg) } & \multirow{2}{*}{$\begin{array}{l}\text { Ontsnapping } \\
\text { door paneel }\end{array}$} \\
\hline & & kuil & paneel & kuil & paneel & \\
\hline Mul & $>18 \mathrm{~cm}$ & 485 & 38 & 54 & 4 & $7 \%$ \\
\hline & $<18 \mathrm{~cm}$ & 475 & 178 & 53 & 18 & $27 \%$ \\
\hline Wijting & alle & 700 & 100 & 117 & 17 & $13 \%$ \\
\hline Poon & $>25 \mathrm{~cm}$ & 780 & 0 & 78 & 0 & $0 \%$ \\
\hline Inktvis & alle & 1000 & 0 & 91 & 0 & $0 \%$ \\
\hline Makreel & alle & 40 & 0 & 40 & 0 & \\
\hline Horsmakreel & alle & 160 & 35 & 53 & 12 & $18 \%$ \\
\hline Totaal & & 8700 & 647 & 580 & 43 & $7 \%$ \\
\hline
\end{tabular}

De voornaamste indicaties uit deze data zijn dat $7 \%$ van de vangst door het paneel ontsnapt, waarvan ongeveer een kwart van de kleinste mul door het paneel zou ontsnappen. Inktvis ontsnapt niet. De hoeveelheden en verhoudingen discards worden echter sterk bepaald door de vangstsamenstelling. In de periode dat deze gegevens verzameld werden, werd veel mul en weinig wijting gevangen wat mogelijks een effect heeft op de hoeveelheden geloosde vis. 


\subsubsection{Methode vangstanalyse}

\subsubsection{Monstername}

Tijdens de vangstanalyse op 14 en 15 januari 2019 werden de vangsten uit de overkuil (maasopening 55.2 $\pm 1.0 \mathrm{~mm}$ ) over het paneel (maasopening $87.8 \pm 2.3 \mathrm{~mm}$ ) vergeleken met die van de standaard kuil. De vangsten van de overkuil werden bij alle 15 trekken volledig opgevangen in manden en vervolgens gesorteerd en geanalyseerd. Tijdens de 10 trekken dat er niet gewerkt werd met camera's werd ook de vangst van de hoofdkuil geanalyseerd. Er werd een monster genomen van 3 grote vismanden $(50-80 \mathrm{~kg})$ van de volledige vangst door met een $10 \mathrm{~L}$ emmer vis te scheppen over de volledige oppervlakte van de uitgestorte vangst, waarbij er op gelet werd om ook dieper te graven en een deel van de vangst van de aanvoerband te scheppen om een zo representatief mogelijk monster te bekomen. Tegelijk werd ook de hoogte van de vangst in de hopper bepaald nadat die was uitgestort en genivelleerd, waarbij de onderkant van de rechte zijwanden als referentie werd genomen. Met deze waarde werd achteraf op basis van de afmetingen en volumes aangegeven op de technische tekeningen het vangstvolume geschat. De verhouding tussen het volume van het genomen monster en de totale vangst werd gebruik om de gewichten en lengtes in het monster op te schalen naar de volledige vangst. Bij vangstanalyses in de toekomst lijkt het aan te raden om, als het weer dit toelaat, rechtstreeks het vangstgewicht in de kuil te bepalen d.m.v. een unster/weegcel.

\subsubsection{Sorteringsproces}

Vervolgens werden de vismanden met hulp van de bemanning naar binnengebracht waar naast de aanvoerband een sorteertafel en weegschalen waren opgesteld. Van elke mand werd voor het sorteren het gewicht en volume bepaald waarna ze op de sorteertafel werd uitgestort en alle dieren werden gesorteerd op soort. Voor schar, schol, tongschar en steenbolk werd de vis boven en onder de minimum landing size (MLS) gescheiden, voor poon gebeurde dit ook maar werd $25 \mathrm{~cm}$ als grens gebruikt. Nadat de volledige vangst van de desbetreffende kuil gesorteerd was werd per soort(fractie) het gewicht bepaald. Van wijting en mul werd bovendien de lengte per individu bepaald om een meer gedetailleerd beeld te krijgen van de ontsnappingskansen per lengte.

\subsubsection{Analyse}

Op basis van de hoogte van de vangst in de manden werd het volume per monster berekend en vergeleken met de schatting van het totaal volume in de hopper. Deze verhouding werd gebruikt om de gewichten en aantallen gemeten in het monster van de kuil op te schalen naar de volledige vangst. De gewichten en aantallen van de overkuil werden niet opgeschaald aangezien die volledig geanalyseerd werden.

Voor de lengte-frequentie grafieken werd gebruikt gemaakt van een generalized LMMs met een polynomiale benadering van de logit functie. Het grillig verloop van de aantallen gevangen in de kuil zijn het gevolg van het opschalen van de metingen gedaan in het monster naar de volledige vangst wat de nauwkeurigheid, zeker bij grote vangst/monster verhoudingen, niet ten goede komt. Een grotere dataset zou dit probleem verhelpen.

\subsubsection{Resultaten waarnemersreis}

De voornaamste vrees bij het gebruik van ontsnappingspanelen is dat veel marktwaardige vis verloren gaat. Net zoals de self-sampling data tonen de gegevens in Tabel 23 aan dat dit niet het geval is. Meer dan $90 \%$ van de ontsnapte vis was wijting. Het verlies aan mul en poon was respectievelijk gemiddeld $2 \mathrm{~kg}$ en $1 \mathrm{~kg}$ per trek maar dit was quasi voornamelijk vis uit de kleinste lengteklasse (Tabel $24 \& 25$ ). Bij alle andere soorten was het verlies minder dan $1 \mathrm{~kg}$ per trek. De commerciële waarde van de vis die door het paneel gaat is dus gering en was tijdens deze waarnemersreis gemiddeld minder dan $€ 10$ mul, $€ 30$ wijting en $€ 10$ andere vis per trek. 
Tabel 24. Het gewicht $(\mathrm{kg})$ per soort dat na ontsnapping door het paneel in de overkuil aangetroffen, weergegeven per bemonsterde trek en gemiddeld over alle bemonsterde trekken.

\begin{tabular}{|c|c|c|c|c|c|c|c|c|c|c|c|c|c|c|}
\hline Trek & 2 & 3 & 4 & 5 & 6 & 7 & 8 & 10 & 11 & 12 & 13 & 14 & 15 & Gemiddelde \\
\hline Horsmakreel & & 0,5 & 0,1 & 0,3 & 0,7 & 0,3 & & 0,1 & 0,1 & 0,5 & & 0,7 & 0,4 & 0,3 \\
\hline Mul & 0,6 & 1,0 & 0,2 & 3,6 & 1,0 & 0,2 & 1,1 & 4,7 & 0,3 & 1,0 & 8,4 & 1,3 & 0,9 & 1,9 \\
\hline Inktvis & & 0,6 & & 0,1 & 0,2 & & 0,3 & & & 0,3 & 0,3 & 0,5 & 0,1 & 0,2 \\
\hline Poon & 0,8 & 1,6 & 0,9 & 0,8 & 2,3 & 0,5 & 1,0 & 1,0 & 0,1 & 2,2 & 1,1 & 1,4 & 1,4 & 1,2 \\
\hline Schar & & & & & & & 0,1 & & & & & 0,1 & & 0,0 \\
\hline Schol & 0,4 & & & & & & 0,0 & & & 0,2 & & 0,1 & 0,2 & 0,1 \\
\hline Steenbolk & 1,0 & 0,2 & 1,0 & & 1,1 & 2,9 & 0,6 & 0,0 & 0,8 & 1,4 & 0,1 & 0,3 & & 0,7 \\
\hline Wijting & 94,8 & 133,8 & 139,8 & 69,0 & 103,6 & 39,1 & 4,3 & 1,2 & 5,6 & 100,1 & 8,1 & 31,5 & 11,8 & 57,1 \\
\hline Totaal & 97,6 & 137,7 & 141,9 & 73,7 & 108,9 & 43,0 & 7,4 & 7,0 & 6,8 & 105,7 & 18,0 & 35,9 & 14,8 & 61,4 \\
\hline
\end{tabular}

Wanneer we voor de doelsoorten van deze studie, wijting, mul en inktvis naast de gewichten van de vis in de overkuil ook de gewichten bekijken van de vis die in de $80 \mathrm{~mm}$ kuil gevangen werd, dan zien we dat de ontsnapping het grootst is voor wijting, waarvan een kwart door het paneel ontsnapte (Tabel 25). Van mul ging er ongeveer $13 \%$ verloren terwijl van inktvis alles gevangen werd. Bovendien zien we dat de gemiddelde vangst van inktvis volgens het logboek van de bemanning mooi in dezelfde lijn ligt van wat berekend werd op basis van de gewichten inktvis in het monster opgeschaald naar het totaal geschat volume in de hopper, 335 vs 314 kg, wat aantoont dat de monstername en berekeningen van het ILVO representatief waren voor de werkelijke vangst. Enkel de gewichten van inktvis werden gebruikt aangezien die van mul veel kleiner zijn, en dus vatbaarder voor fouten, en de gewichten van wijting in het logboek geen rekening houden met wat gediscard werd.

Tabel 25. Het totale gewicht $(\mathbf{k g})$ van alle wijting, mul en inktvis die gevangen werden in de 80 mm kuil of ontsnapten door het paneel ('Vangst in overkuil') weergegeven per trek met onderaan het gemiddelde gewichten per trek ('Gemiddeld') en het percentage ontsnapping ('Ontsnapping') gebaseerd op de gewichten.

\begin{tabular}{|c|c|c|c|c|c|c|c|c|c|}
\hline \multirow[t]{3}{*}{ Trek } & \multicolumn{5}{|c|}{ Vangst $80 \mathrm{~mm}$ kuil } & \multicolumn{4}{|c|}{ Vangst in overkuil } \\
\hline & \multirow[t]{2}{*}{ Totaal } & \multirow{2}{*}{$\begin{array}{c}\text { Logboek } \\
\text { Inktvis }\end{array}$} & \multicolumn{3}{|c|}{ Monstername } & \multirow[t]{2}{*}{ Totaal } & \multirow[t]{2}{*}{ Inktvis } & \multirow[t]{2}{*}{ Mul } & \multirow[t]{2}{*}{ Wijting } \\
\hline & & & Inktvis & Mul & Wijting & & & & \\
\hline 2 & 1614 & 340 & 433 & 14 & 286 & 98 & & 0,6 & 95 \\
\hline 3 & 1164 & 380 & 314 & 8 & 265 & 138 & 0,6 & 1,0 & 134 \\
\hline 4 & 1935 & 500 & 522 & 14 & 665 & 142 & & 0,2 & 140 \\
\hline 5 & & 420 & & & & 74 & 0,1 & 3,6 & 69 \\
\hline 6 & & 380 & & & & 109 & 0,2 & 1,0 & 104 \\
\hline 7 & 1614 & 380 & 297 & 8 & 160 & 43 & & 0,2 & 39 \\
\hline 8 & 586 & 450 & 314 & 12 & 50 & 7 & 0,3 & 1,1 & 4 \\
\hline 10 & 650 & 220 & 372 & 23 & 11 & 7 & & 4,7 & 1 \\
\hline 11 & 586 & 220 & 150 & 1 & 64 & 7 & & 0,3 & 6 \\
\hline 12 & 1164 & 300 & 408 & 3 & 109 & 106 & 0,3 & 1,0 & 100 \\
\hline 13 & 586 & 240 & 180 & 33 & 25 & 18 & 0,3 & 8,4 & 8 \\
\hline 14 & 972 & 260 & 146 & 11 & 63 & 36 & 0,5 & 1,3 & 32 \\
\hline 15 & & 270 & & & & 15 & 0,1 & 0,9 & 12 \\
\hline Gemiddeld & 1087 & 335 & 314 & 13 & 170 & 61 & 0,3 & 1,9 & 57 \\
\hline Ontsnapping & & & & & & $5 \%$ & $0 \%$ & $13 \%$ & $25 \%$ \\
\hline
\end{tabular}




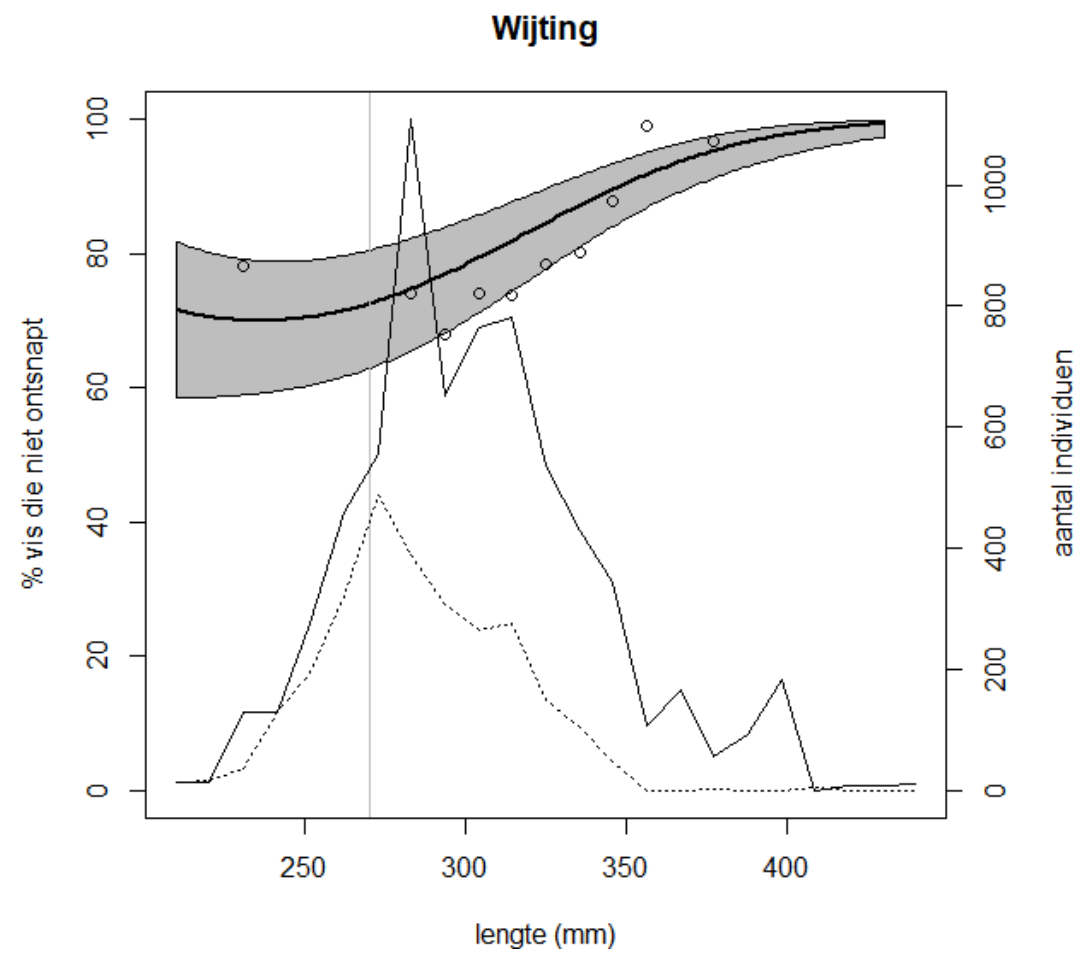

Figuur 43. Lengte-frequentie verdeling van wijting met het aantal gevangen individuen in functie van de lengte. De volle zwarte grafieklijn geeft het aantal wijting in de $80 \mathrm{~mm}$ kuil, terwijl de stippellijn eronder het aantal vissen geeft die door het paneel ontsnapte. De linker verticale as geeft een schatting van het percentage wijting van die grootte die niet ontsnapt en in de kuil terecht komt. Die werd berekend door per lengte een proportie te berekenen (vissen in 80 mm kuil t.o.v. het totaal), weergegeven als een bolletje, en daar een trend door te modelleren. De trendlijn is de dikke zwarte lijn in het midden van de grijze band die de breedte van het betrouwbaarheidsinterval weergeeft. Deze trendlijn schat de kans geeft dat een vis die het net binnenkomt niet ontsnapt en in de $80 \mathrm{~mm}$ kuil terecht komt. (data van 10 trekken)

Wanneer we nu gaan kijken naar lengte van de dieren die door het paneel ontsnappen (Figuur 43 \& 44), dan bevestigen de cijfers het vermoeden dat het vooral de kleinere dieren zijn die zich door het paneel kunnen murwen. In beide gevallen toont de trendlijn in de grijze band aan dat de ontsnapping het grootst is voor de kleine dieren en afneemt naar $0 \%$ voor de grootste dieren. Bij wijting zien we ook bij klasse 4 (tot $32 \mathrm{~cm}$ ) nog behoorlijk wat ontsnapping (Figuur 43), terwijl bij mul het verlies bijna uitsluitend plaatsvindt bij dieren kleiner dan $20 \mathrm{~cm}$ (Figuur 44 links). Wanneer we inzoomen op de grotere lengteklasses van mul (Figuur 44 rechts) dan zien we dat de ontsnapping door het paneel verwaarloosbaar is.

Het hoekige profiel van de lengteverdeling van de $80 \mathrm{~mm}$ kuil zijn te wijten aan het sterke opschaaleffect doordat de monsters een relatief klein deel van de vangst betroffen en er slechts 10 trekken in detail bemonsterd werden. 

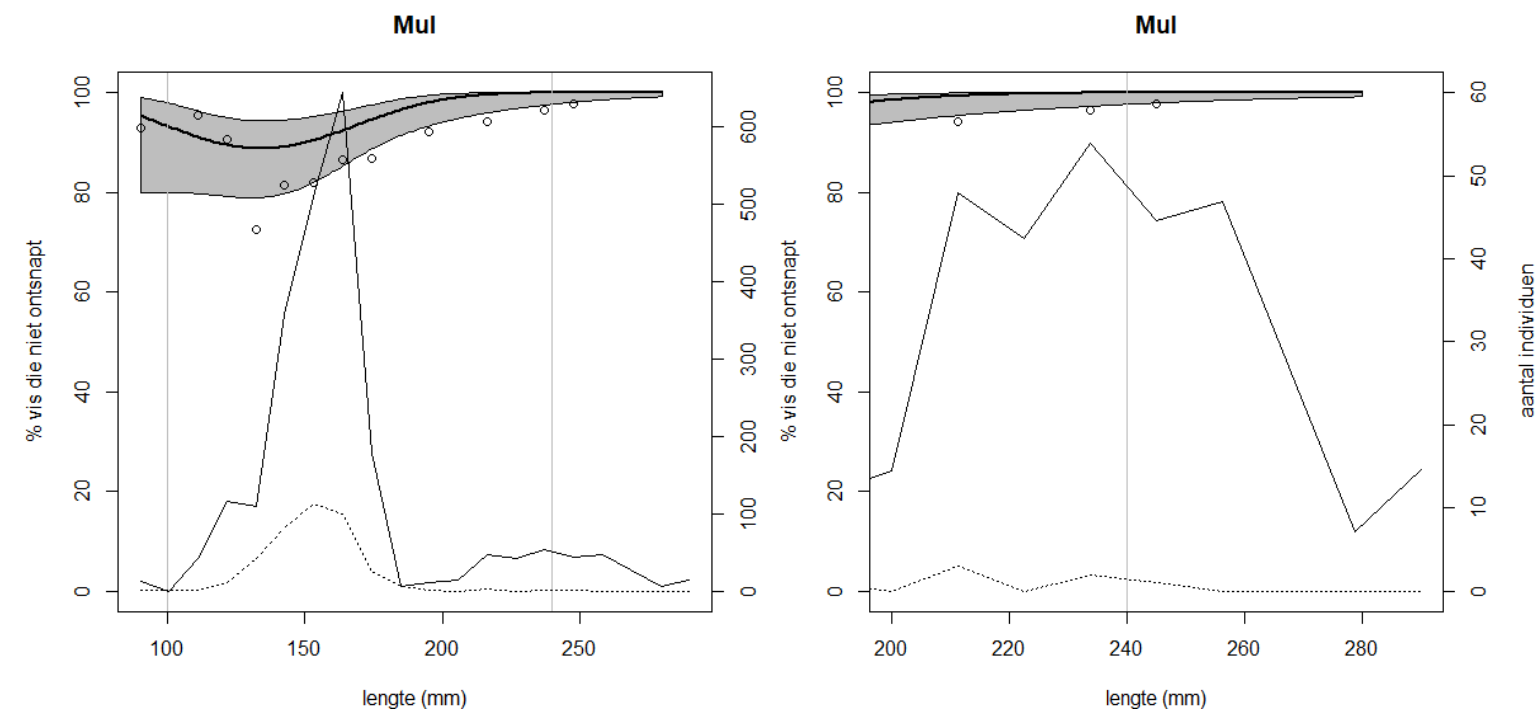

Figuur 44. Lengte-frequentie verdelingen van alle mul (links) en enkel de grote mul (rechts) met het aantal gevangen individuen per grootte. De volle zwarte grafieklijn geeft het aantal wijting in de 80 mm kuil, terwijl de stippellijn eronder het aantal vissen geeft die door het paneel ontsnapte. De linker verticale as geeft een schatting van het percentage mul van die grootte die niet ontsnapt en in de kuil terecht komt. Die werd berekend door per lengte een proportie te berekenen (vissen in 80 mm kuil t.o.v. het totaal), weergegeven als een bolletje, en daar een trend door te modelleren. De trendlijn is de dikke zwarte lijn in het midden van de grijze band die de breedte van het betrouwbaarheidsinterval weergeeft. Deze trendlijn schat de kans geeft dat een vis die het net binnenkomt niet ontsnapt en in de $80 \mathrm{~mm}$ kuil terecht komt (data van 10 trekken).

Wanneer we de verliezen gaan bekijken per commerciële lengteklasse dan worden Figuur 43 en 44 vertaald in concrete cijfers en zien we dat het procentueel verlies het grootst is voor de kleinste vissen met het minst aanlandingswaarde (Tabel 26). Het verlies van wat als kleine mul beschouwd wordt is ongeveer $19 \%$, terwijl het voor grotere mul verwaarloosbaar is. Voor wijting zien we dezelfde trend met een verlies van $48 \%$ voor ondermaatse wijting en $29 \%$ verlies van wijting klasse 4 , voor de grotere vis is het verlies nog kleiner. De ontsnapping van ongeveer de helft van de ondermaatse wijting bevestigt heel duidelijk de effectiviteit aan van het paneel om ondermaatse wijting te lozen.

Tabel 26. Gemiddelde procentuele ontsnapping doorheen het paneel per lengteklasse voor wijting en mul op basis van aantal individuen. (10 trekken)

\begin{tabular}{|c|c|c|c|c|c|c|c|c|c|}
\hline \multicolumn{5}{|c|}{ Wijting } & \multicolumn{5}{|c|}{ Mul } \\
\hline Ondermaats & Klasse & Klasse & Klasse & Klasse & Kleine mul & Klasse & Klasse & Klasse & Klasse \\
\hline & 4 & 3 & 2 & 1 & & 4 & 3 & 2 & 1 \\
\hline \multirow[t]{2}{*}{$<27 \mathrm{~cm}$} & $27-32$ & $32-36$ & $36-40$ & $>40$ & $<18 \mathrm{~cm}$ & $<10$ & $10-24$ & $24-33$ & $>33$ \\
\hline & $\mathrm{cm}$ & $\mathrm{cm}$ & $\mathrm{cm}$ & $\mathrm{cm}$ & & $\mathrm{cm}$ & $\mathrm{cm}$ & $\mathrm{cm}$ & $\mathrm{cm}$ \\
\hline $48 \%$ & $29 \%$ & $13 \%$ & $4 \%$ & $0 \%$ & $19 \%$ & $7 \%$ & $19 \%$ & $1 \%$ & $0 \%$ \\
\hline
\end{tabular}

Tot slot geven we in Tabel 27 ook nog de procentuele ontsnapping doorheen het paneel van de andere soorten commerciële vis die tijdens deze trip bemonsterd werden. Deze cijfers geven nogmaals aan dat er buiten van wijting en mul geen marktwaardige vis ontsnapt, op 1.5\% kleine horsmakreel na. Bovendien blijkt het paneel ook een significante hoeveelheid ondermaatse steenbolk $( \pm 15 \%)$ te lozen.

Tabel 27. Gemiddelde procentuele ontsnapping doorheen het paneel per soort op basis van gewicht. (10 trekken).

\begin{tabular}{|c|c|c|c|c|c|}
\hline Inktvis & Horsmakreel & \multicolumn{2}{|c|}{ Poon } & \multicolumn{2}{|c|}{ Steenbolk } \\
\hline alle & alle & $<25 \mathrm{~cm}$ & $>25 \mathrm{~cm}$ & $<27 \mathrm{~cm}$ & $>27 \mathrm{~cm}$ \\
\hline $0.1 \%$ & $1.5 \%$ & $1,8 \%$ & $0,0 \%$ & $5,6 \%$ & $0,0 \%$ \\
\hline \multicolumn{2}{|c|}{ Schar } & \multicolumn{2}{|c|}{ Schol } & \multicolumn{2}{|c|}{ Tongschar } \\
\hline$<25 \mathrm{~cm}$ & $>25 \mathrm{~cm}$ & $<27 \mathrm{~cm}$ & $>27 \mathrm{~cm}$ & $<25 \mathrm{~cm}$ & $>25 \mathrm{~cm}$ \\
\hline $0,1 \%$ & $0,0 \%$ & $0,1 \%$ & $0,0 \%$ & $0,0 \%$ & $0,0 \%$ \\
\hline
\end{tabular}




\subsubsection{Discussie}

De resultaten bekomen op de $\mathrm{SCH} 135$ bevestigen dat een ontsnappingspaneel in de rug van het net met vierkante mazen en een maasopening ongeveer $90 \mathrm{~mm}$ uitstekend geschikt is om ondermaatse wijting te lozen. Dit wordt bevestigd door zowel de eerste ruwe schattingen gemaakt door de schipper tijdens de selfsampling ('ss') (Tabel 23) als de gedetailleerde vangstanalyse tijdens de waarnemersreis ('wr') (Tabel 24 \& 25). De inschatting van de van de schipper lijkt eerder pessimistisch met een overschatting van de hoeveelheid ontsnapte mul en vooral horsmakreel en een onderschatting van de hoeveelheid ontsnapte wijting in de overkuil, al kunnen de verschillen ook deels verklaard worden door het verschil in vangstsamenstelling:

- Totale ontsnapping door paneel: $7 \%$ (ss) t.o.v. 5\% (wr)

- Ontsnapping wijting door paneel: $13 \%$ (ss) t.o.v. $25 \%$ (wr)

- Ontsnapping mul door paneel: $18 \%$ (ss) t.o.v. $13 \%$ (wr)

- Ontsnapping inktvis door paneel: 0\% (ss) t.o.v. 0.1\% (wr)

- Ontsnapping horsmakreel door paneel: $18 \%$ (ss) t.o.v. $1.5 \%$ (wr)

De gegevens uit de waarnemersreis tonen twee belangrijke zaken. Enerzijds dat ongeveer de helft van de ondermaatse wijting (48\%) kan ontsnappen door het geteste paneel. Anderzijds dat er geen noemenswaardige ontsnapping plaatsvindt van platvis en dat de ontsnapping bij rondvis vooral plaatsvindt bij kleinere, minder waardevolle, lengteklasses. Grotere mul en inktvis werden wel volledig weerhouden in de vangst. Het enige economisch significante vangstverlies lijkt dus de kleinere mul (waarvan het verlies op $19 \%$ geschat werd) en de wijting van klasse 4 en 3 . Deze bevindingen bewijzen het nut van een ontsnappingspaneel als netaanpassing om de bijvangst van ondermaatse wijting aan te pakken met het oog op de aanlandingsplicht.

De camerabeelden tonen aan dat de overkuil de ontsnapping niet belemmerde, maar desondanks kan een beperking op de ontsnapping niet uitgesloten worden aangezien een paneel zonder overkuil een andere doorstroming en lichtinval zal kennen.

\subsubsection{Conclusie}

De vangstanalyses op de $\mathrm{SCH} 135$ bewijzen dat ongeveer de helft van de ondermaatse wijting ontsnapt door een paneel met vierkante mazen (maasopening $87.8 \pm 2.3 \mathrm{~mm}$ ) in de rug van het net $10 \mathrm{~m}$ voor de kuil. Voor de voornaamste andere doelsoorten kwam het verlies op ongeveer $20 \%$ voor mul kleiner dan $18 \mathrm{~cm}$, 29 en 13\% voor wijting van klasse 4 en 3 en $1.5 \%$ voor horsmakreel. Voor mul van klasse 1 en 2 , inktvis, poon, steenbolk en platvis was de ontsnapping doorheen het paneel afwezig of verwaarloosbaar.

\subsection{Conclusies en aanbevelingen}

\subsubsection{Eindconclusies}

De bestaande kennis over het gedrag van wijting en andere soorten zoals mul, makreel en inktvis in flyshootvisserij is zeer beperkt, maar de beschikbare info over het gedrag in andere types visserijen werd grotendeels bevestigd in deze studie, waarvan de voornaamste waren:

- Wijting zoekt de bovenkant van de staart op en zal opwaarts of zijdelings trachten te ontsnappen, zeker na contact met het paneel. Golven in het ontsnappingspaneel maken (zijdelingse) ontsnapping makkelijker.

- Lampjes op en rond het paneel leken de vis nerveuzer te maken, wat mogelijk zijn kans op contact met het paneel en dus ontsnapping zou kunnen vergroten. Witte en rode touwen hadden geen merkbaar effect op het gedrag of de ontsnapping van wijting.

- De overkuil leek de ontsnapping niet actief te belemmeren, maar het effect van een verschillende doorstroming en licht kan niet ingeschat worden.

- Ontsnapping van commerciële vis was beperkt tot kleine mul en wijting. Grote mul, inktvis, grote poon en platvis ontsnappen niet door het geteste paneel. 
De observaties van de onderwaterbeelden vertaalden zich mooi in de resultaten van de vangstanalyse, waarbij meer dan $90 \%$ van de vangst in de overkuil bestond uit wijting. De vangstanalyse toonde aan dat ongeveer de helft van de ondermaatse wijting ontsnapte door een paneel met vierkante mazen (maasopening $87.8 \pm 2.3 \mathrm{~mm}$ ) in de rug van het net $10 \mathrm{~m}$ voor de kuil. Voor de voornaamste andere doelsoorten kwam het verlies op ongeveer $20 \%$ voor mul kleiner dan $18 \mathrm{~cm}$, 29 en $13 \%$ voor wijting van klasse 4 en 3 en $1.5 \%$ voor horsmakreel. Mul van klasse 1 en 2, inktvis, poon, steenbolk en platvis ontsnapten niet door het paneel.

\subsubsection{Suggesties verder onderzoek}

In een vervolgproject zou er gezocht kunnen worden naar manieren om de ontsnapping van ondermaatse wijting doorheen het paneel verder te verbeteren. Studies in andere visserijen met wijting en ontsnappingspanelen toonden enkele relevante aanknopingspunten aan:

- Het vergroten van de vierkante mazen vergroot het verlies van ondermaatse wijting maar laat wel meer maatse vis ontsnappen. Dit wordt ook bevestigd door de lengte-frequentie verdeling van de wijting in de overkuil die piekte bij $27 \mathrm{~cm}$. Grotere mazen testen is dus minder zinvol.

- Hoe dichter het paneel bij de kuil zit, hoe efficiënter. In deze experimenten zat het paneel 10 meter voor de kuil. Dit zou verkleint kunnen worden tot 5 of 3 meter.

- Het paneel verlengen waardoor de wijting meer tijd krijgt om te ontsnappen.

- Het paneel verbreden richting de rijgingen zodat zijdelingse ontsnapping makkelijker wordt.

- Het gebruik van de onderwaterlampen verder testen aangezien deze wijting leken te agiteren. Hierbij kan gekeken worden naar het effect van de kleur van het licht en de plaats van de lampjes (boven of op het paneel, op het einde of aan de zijkanten) op de ontsnapping van wijting en mul. 


\section{Schol visserij}

\subsection{Inleiding}

De scholvisserij met gesleepte tuigen met een maaswijdte $100+\mathrm{mm}$ in de kuil wordt voornamelijk seizoensmatig beoefend in de zomermaanden. Voor deze visserij worden twin-rig ottertrawls (OTB) en boomkortuigen (BT) gebruikt, waarbij kuilen gebruikt worden van $110 \mathrm{~mm}$ en $115 \mathrm{~mm}$ en in mindere mate $120 \mathrm{~mm}$. De vangst bestaat hoofdzakelijk uit marktwaardige schol met geringe bijvangsten van tarbot, griet, tongschar en rondvis (Verkempynck et al., 2018). Ongewenste bijvangst bestaat voornamelijk uit ondermaatse schol, schar en in minder mate uit verschillende soorten roggen (Verkempynck et al., 2018). Onder de huidige aanlandplicht (European Union, 2013) vormen vooral de bijvangst van ondermaatse schol en rog een aandachtspunt. In NIKO1 is er om de bijvangst van ondermaatse schol en schar te beperken in deze visserij getest met een kuil waarvan de mazen 90 graden gedraaid waren (T90), de proeven hadden niet het gewenste effect (van Marlen et al. 2016).

\subsection{Bijvangst beperkende net-aanpassingen}

Voor het beperken van de vangst van ongewenste bijvangst van ondermaatse schol (en schar) kan er in deze visserij gekozen worden om een grotere maaswijdte (120-140mm) voor de kuil te gebruiken. Echter, gaat het verminderen van de bijvangst van ondermaatse schol gepaard met een verlies van marktwaardige en waardevolle tongschar. Er is daarom beperkt animo voor het vissen met grotere maaswijdtes.

Een verminderd gevoel van urgentie kan mogelijk een rol gespeeld hebben bij het uitblijven van experimentele netontwerpen voor de scholvisserij. De regelgeving is aangepast halverwege 2016, vissers uit het BT2-segment (boomkor/puls 80-119 mm) konden vanaf toen ook gebruik maken van de zeedagen uit het BT1-segment (boomkor/puls $>120 \mathrm{~mm}$ ). Dit betekende concreet dat scholvissers met mazen wijder dan $119 \mathrm{~mm}$ konden vissen zonder beperkt te worden in dagen dat ze op zee mochten zijn. Het vergroten van de maaswijdte in deze visserij kan aanzienlijk bijdragen in het verminderen van discards.

Het beperken van de ongewenste bijvangst van rog vraagt gezien het formaat van deze dieren om andere aanpassingen. Het vergoten van de maaswijdte wordt niet effectief geacht voor het verminderen van bijvangsten van roggen. Aan de hand van een internationale QuickScan naar het beperken van de bijvangst van rog zijn een tweetal aanpassingen voorgesteld; (i) een scheidingspaneel of -rooster die de grotere roggen van de overige vangst moeten scheiden of (ii) het vissen zonder wekkerketting(en) in een twin-rig ottertrawl (Kynoch et al. 2015). Daarnaast is er tijdens de studiereis naar Zweden geïnformeerd naar mogelijke technische oplossingen (bijlage 8). De Nederlandse Vissersbond heeft onderzocht of er animo was onder de scholvissers om aanpassingen uit de testen. De vissers gaven aan dat bovengenoemde aanpassingen waarschijnlijk ook de vangst van de waardevolle tarbot en griet beperken, gezien zowel grote rog, tarbot en griet een vergelijkbare vorm hebben. Omdat een deel van de besomming van een scholkotter bestaat uit de bijvangst van griet en tarbot was er geen animo om deze aanpassingen te testen. 


\section{Conclusies en aanbevelingen}

\subsection{Tongvisserij}

\subsubsection{Elektrisch benthos ontsnappingspaneel (eBRP)}

De proeven tonen aan dat met een eBRP succesvol bijvangst van benthos en stenen gereduceerd kan worden zonder verlies van maatse tong. Het effect op visdiscards kon niet onderzocht worden door een gebrek aan data, maar er waren geen aanwijzingen dat het gebruik van een eBRP tot noemenswaardige reducties leidde van ondermaatse platvis of rondvis. Een eBRP lijkt voorlopig dus vooral een meerwaarde voor zwaarder vissende boom- of pulskorvaartuigen, waar het lozen van grote hoeveelheden benthos en stenen een significante verbetering kan betekenen voor de viskwaliteit en de mogelijk de selectiviteit in de kuil. Een verbetering in kwaliteit en dus de visconditie van de vissen zou ook een verbetering van de overleving van de discards kunnen beteken. Het wordt aanbevolen om in vervolgonderzoek beide aspecten mee te nemen. De ontwikkeling van pulsmodules die bruikbaar zijn in het net opent nieuwe mogelijkheden om tot een verbeterde scheiding en/of selectiviteit te komen in de staart van het net.

\subsubsection{Touwtjespaneel}

Het touwtjespaneel was ontworpen om tong en schol te scheiden, waarbij tong in de onderkuil en schol in een bovenkuil opgevangen werd. Essentieel hiervoor is een effectieve scheiding van beide soorten. Dit was echter niet het geval. In de eerste versie per trek het percentage schol en tong in beide kuilen nagenoeg gelijk. Voor het verlengde touwtjespaneel werd echter een groter verschil in de percentages tussen de soorten waargenomen, dit was niet voldoende om dit paneel commercieel toe te passen. Een vervolg zou zich kunnen focussen op het optimaliseren van de passeerbaarheid van het paneel voor tong waarbij onderwateropnames op het paneel tijdens het vissen mogelijk nieuwe inzichten leveren.

\subsubsection{Pulse Selector}

Met het toepassen van het Pulse selector concept werd geen verlies van marktwaardige vis ten opzichte van het conventionele net waargenomen. Echter was de uitvoering van de borstelpees en extra tunnel en kuil achter de borstelpees niet optimaal waardoor over de effectiviteit van de innovatie op het scheiden van tong en overige vis beperkt uitspraken gedaan kunnen worden. Een vervolg test is aan te raden waarbij de borstels van de pees aan beide uiteinden verlengd worden en de extra tunnel beter in het net bevestigd wordt.

\subsubsection{Schanspaneel}

Met het schanspaneel met en zonder extra onderpees werd aanzienlijk meer ondermaatse wijting gevangen in het net conventionele tuig. Het toepassen van een lichte extra onderpees met schanspaneel had als gevolg dat er gemiddeld per trek (14.7\%) minder tong gevangen werd ten opzichte van het bakboord tuig. In het geval het schanspaneel nogmaals getest wordt is het aan te bevelen om de licht onderpees over de bodem te laten lopen en het paneel hier direct aan te bevestigen. Dit voorkomt dat er ruimte ontstaat tussen de pees en begin van het paneel waardoor wijting er alsnog onderdoor gaat. Video observaties voor de extra onderpees kunnen mogelijk inzicht bieden in het gedrag van zowel tong als wijting en de gevonden verschillen verklaren.

\subsubsection{Kiwikuil}

De vangsten van marktwaardige vis waren in de verlengde kiwikuil aanzienlijk minder dan de conventionele kuil. Dit is mogelijk een gevolg van een beperkte waterstroming door de kiwikuil, het is aan te bevelen om 
een vervolgontwerp langer te maken en van meer openingen te voorzien. Ook wordt aanbevolen om de openingen in de kiwikuil te optimaliseren naar de breedte en dikte van de kleinste marktwaardige tong $(24 \mathrm{~cm})$. Voor ondermaatse schol uit de verlengde kiwikuil worden minder beschadigingen waargenomen ten opzichte van de conventionele kuil. Hoewel er minder beschadigingen waargenomen worden is er nog steeds een aanzienlijk percentage van de vissen beschadigd. Indien de vangst efficiëntie en doorstroming van de kiwikuil verbeterd is dient het de aanbeveling om de beschadigingen opnieuw te classificeren, mogelijk heeft een verbeterde doorstroming minder beschadigingen tot gevolg. Ook de ophoping van zand in de kiwikuil is een aandachtspunt, met het aanbrengen van meer openingen in de onderzijde van de kiwikuil wordt dit mogelijk verminderd.

\subsubsection{Luchtpuls}

Met de luchtpuls geprobeerd om met luchtdruk en dus luchtbellen boven de bodem de vis te stimuleren om de bodem te verlaten. Echter, laten de proeven zien dat in de gebruikte opstelling een zeer beperkt aantal vissen reageert op de luchtbellen. Daarmee lijkt deze methode in deze opstelling nog geen alternatief voor wekkerkettingen of puls gezien de beperkte effectiviteit waarmee tong en schol gestimuleerd worden om de bodem te verlaten.

\subsection{Noorse kreeften visserij}

\subsubsection{SepNep}

De verbetering van de effectiviteit van het SepNep paneel is behaald door het toevoegen van drijfvermogen onder het paneel. Daarnaast is tijdens een week vergelijkend vissen naar voren gekomen dat SepNep $97 \%$ van de Noorse kreeften vangt in vergelijking met conventionele netten. Aanbevolen wordt te onderzoeken hoe dit netontwerp breder in de vloot opgepakt kan worden, waarbij een oplossing gezocht wordt voor praktische moeilijkheden welke sommige schepen ervaren bij het halen, zetten en schoonhouden van de SepNep netten. Ook zou een vangstvergelijking met verbeterde SepNep panelen en conventionele Noorse kreeften netten informatief zijn om de bijvangst vermindering in de commerciële situatie nogmaals te classificeren. Het optionele grid dat gebruikt kan worden naast het SepNep paneel biedt een oplossing om de kleine niet marktwaardige Noorse kreeften te laten ontsnappen, het dient de aanbeveling om dit grid verder te optimaliseren voor commerciële toepassingen.

\subsubsection{Swedish grid}

De resultaten van de waarnemersreis met het Swedish grid lieten zien dat het huidige ontwerp $61 \%$ van de ondermaatse schol, $24 \%$ ondermaatse wijting en $33 \%$ schar het grid niet passeerden en in de bovenkuil gevangen werden. Dit betreft het gemiddelde resultaat van 7 bemonsterde trekken waarbij het grid niet in de juiste positie stond tijdens 3 trekken, de resultaten van de individuele trekken waarbij het grid in de juiste positie stond geven een indicatie dat het grid effectiever kan werken. De verder ontwikkeling van het grid moet zich daarom focussen op de stabiliteit van het ontwerp tijdens het vissen. Gezien de minimale vangsten van marktwaardige Noorse kreeft in de bovenkuil (80 mm maaswijdte) kan deze vervangen worden voor een $120+\mathrm{mm}$ bovenkuil. Het dient de aanbeveling om met een stabiel grid en een $120+\mathrm{mm}$ bovenkuil de reductie in ongewenste bijvangst opnieuw de classificeren om een beter beeld te krijgen van de bijvangstreductie. Het huidige ontwerp voorziet nog niet in een oplossing om de kleine niet marktwaardige Noorse kreeften te laten ontsnappen, dit zou mogelijk aanvullingen kunnen zijn op een toekomstig ontwerp.

\subsection{Flyshoot}

De experimenten lieten zien dat de bijvangst van ondermaatse wijting gehalveerd kan worden door 10 meter voor de kuil een paneel met vierkante mazen (maaswijdte $87.8 \mathrm{~mm}$ ) in de bovenzijde van het net te maken. Het verlies door het toepassen van dit paneel op de voornaamste andere doelsoorten was ongeveer 
$20 \%$ voor mul kleiner dan $18 \mathrm{~cm}, 29$ en $13 \%$ voor wijting van klasse 4 en 3 en 1.5\% voor horsmakreel. Mul van klasse 1 en 2 , inktvis, poon, steenbolk en platvis ontsnapten niet door het paneel.

Om de werking van het paneel te verbeteren en een grotere deel van de wijting te laten opstappen aanbevolen om te experimenteren met een paneel dat dichter bij de kuil gepositioneerd is, er kan eventueel aan 3 tot 5 meter van de kuil gedacht worden. Daarnaast zou het paneel efficiënter kunnen zijn als het langer en/of breder gemaakt wordt.

\subsection{Scholvisserij}

Door een aanpassing van de regelgeving kunnen vissers uit het BT2-segment (boomkor/puls 80-119 mm) ook gebruik maken van de zeedagen uit het BT1-segment (boomkor/puls >120 mm). Hierdoor kunnen scholvissers met een kuil met mazen wijder dan $119 \mathrm{~mm}$ vissen zonder beperkt te worden in dagen dat ze op zee mogen zijn. Het vergroten van de maaswijdte van de kuil in deze visserij draagt bij aan een vermindering van ongewenste bijvangsten. Het beperken van de ongewenste bijvangst van rog vraagt gezien het formaat van deze dieren om andere aanpassingen, indien dit urgent bevonden wordt kan hier specifiek een oplossing voor gezocht worden. 


\section{Kwaliteitsborging}

Wageningen Marine Research beschikt over een ISO 9001:2015 gecertificeerd

kwaliteitsmanagementsysteem. Dit certificaat is geldig tot 15 december 2021. De organisatie is gecertificeerd sinds 27 februari 2001. De certificering is uitgevoerd door DNV GL.

Het chemisch laboratorium te IJmuiden beschikt over een NEN-EN-ISO/IEC 17025:2005 accreditatie voor testlaboratoria met nummer L097. Deze accreditatie is geldig tot 1 april 2021 en is voor het eerst verleend op 27 maart 1997; deze accreditatie is verleend door de Raad voor Accreditatie. Het chemisch laboratorium heeft hierdoor aangetoond in staat te zijn op technisch bekwame wijze valide resultaten te leveren en te werken volgens de ISO17025 norm. De scope (L097) met de geaccrediteerde analysemethoden is te vinden op de website van de Raad voor Accreditatie (www.rva.nl).

Op grond van deze accreditatie is het kwaliteitskenmerk $\mathrm{Q}$ toegekend aan de resultaten van die componenten die op de scope staan vermeld, mits aan alle kwaliteitseisen is voldaan. Het kwaliteitskenmerk $Q$ staat vermeld in de tabellen met de onderzoeksresultaten. Indien het kwaliteitskenmerk $Q$ niet staat vermeld is de reden hiervan vermeld.

De kwaliteit van de analysemethoden wordt op verschillende manieren gewaarborgd. De juistheid van de analysemethoden wordt regelmatig getoetst door deelname aan ringonderzoeken waaronder die georganiseerd door QUASIMEME. Indien geen ringonderzoek voorhanden is, wordt een tweede lijnscontrole uitgevoerd. Tevens wordt bij iedere meetserie een eerstelijnscontrole uitgevoerd.

Naast de lijnscontroles wordende volgende algemene kwaliteitscontroles uitgevoerd:

- Blanco onderzoek.

- Terugvinding (recovery).

- Interne standaard voor borging opwerkmethode.

- Injectie standard.

- Gevoeligheid.

Bovenstaande controles staan beschreven in Wageningen Marine Research werkvoorschrift ISW 2.10.2.105. Indien gewenst kunnen gegevens met betrekking tot de prestatiekenmerken van de analysemethoden bij het chemisch laboratorium worden opgevraagd.

Indien sprake is van onbeheerste kwaliteit worden passende maatregelen genomen. 


\section{Literatuur}

Bayse, S., Herrmann, B., Lenoir, H., Depestele, J., Polet, H., Vanderperren, E., Verschueren, B., 2015. Could a T90 mesh codend improve selectivity in the Belgian beam trawl fishery?. In: Fisheries Research, Vol. 174, 2015, blz. 201-209.

European Union, 2013. Regulation (EU) No 1380/2013 of the European Parliament and of the Council of 11 December 2013 on the Common Fisheries Policy, amending Council Regulations (EC) No 1954/2003 and (EC) No 1224/2009 and repealing Council Regulations (EC) No 2371/2002 and (EC) No 639/2004 and Council Decision 2004/585/EC. Official Journal of the European Union L, 354: 22-61.

Kynoch, R., Fryer, R., Neat, F. 2015. A simple technical measure to reduce bycatch and discard of skates and sharks in mixed-species bottom-trawl fisheries. ICES Journal of Marine Science, doi:10.1093/icesjms/fsv037

Kraan, M., Uhlmann, S., Steenbergen, J., Van Helmond, A. T. M. and Van Hoof, L. 2013. The optimal process of self-sampling in fisheries: lessons learned in the Netherlandsa. J Fish Biol, 83: 963-973. doi: $10.1111 / \mathrm{jfb} .12192$

Molenaar, P., Chen, C., Cod-end selectivity for sole (Solea solea) and plaice (Pleuronectes platessa) in North Sea pulse-trawl fisheries, 2018. Best Practices II - WP4 selectivity Wageningen, Wageningen Marine Research (University \& Research centre), Wageningen Marine Research report C049/18. 30 pp.

Molenaar, P., Dammers, M., van Rijn, J. 2018. Platvis in beeld; stimulans voor netinnovatie in de tongvisserij. Wageningen Marine Research Wageningen UR (University \& Research centre), Wageningen Marine Research rapport C026/18. 20 blz.

Molenaar, P., Steenbergen, J., Glorius, S., Dammers M., 2016. Vermindering discards door netinnovatie in de Noorse Kreeft visserij. Wageningen Marine Research. IMARES rapport C027/16

Schram; E., and Molenaar, P. 2018. Discards survival probabilities of flatfish and rays in North Sea pulsetrawl fisheries. Wageningen, Wageningen Marine Research (University \& Research centre), Wageningen Marine Research report C037/18. 39 pp.

Santos, J., Molenaar, P., 2016. Bericht über die 725. Reise des FFS Solea vom 07.09 bis 23.09.2016. Thünen Institut Für Ostseefischerei. 44pp

Soetaert, M., Lenoir, H., and Verschueren, B. 2018. Reducing bycatch in beam trawls and electrotrawls with (electrified) benthos release panels. ICES Journal of Marine Science, doi:10.1093/icesjms/fsw096.

Steenbergen, J., Machiels M., Nijman, R., 2012. LFD: Less Fuel \& Discards in visserij op Noorse kreeft. Eindrapportage. IMARES Rapport 036.12

TECHVIS IWT LBO - LA 120755 - TECHnische innovaties voor een transitie naar een duurzame zeeVISserijsector.

Valentinsson D., Ulmestrand M. 2007. Species-selective Nephrops trawling: Swedish grid experiments. Fisheries Research 90 (2008) 109-117

Van der Reijden, K., Molenaar, P., Chen, C., Uhlmann, S., Goudswaard, C., and van Marlen, B. 2017. Survival of undersized plaice (Pleuronectes platessa), sole (Solea solea), and dab (Limanda limanda) in North Sea pulse-trawl fisheries. ICES Journal of Marine Science, 74: 1672-1680. 
van Marlen, B., Bol, R., Groeneveld, K., Nijman, R., Rink, G., Buyvoets E., 2013. Vermindering discards door technische aanpassingen in de netten (VIP - VDTN). IMARES Rapport C127/13

van Marlen, B. Molenaar, P., Bol, R., Dammers, M. Groeneveld, K., den Heijer, W.M., Machiels, M.A.M., 2016. Netinnovatie kottervisserij. Wageningen Marine Research. IMARES rapport C110/15

Verkempynck R., van Overzee H. \& Dammers M., 2018. Discard self-sampling of Dutch bottom-trawl and seine fisheries in 2014-2016. CVO Report 18.007. https://doi.org/10.18174/446002. 


\section{Verantwoording}

Rapport C051/19

Projectnummer: 4311400006

Dit rapport is met grote zorgvuldigheid tot stand gekomen. De wetenschappelijke kwaliteit is intern getoetst door een collega-onderzoeker en het verantwoordelijk lid van het managementteam van Wageningen Marine Research

Akkoord:
Handtekening

Edward Schram

Onderzoeker Visserij

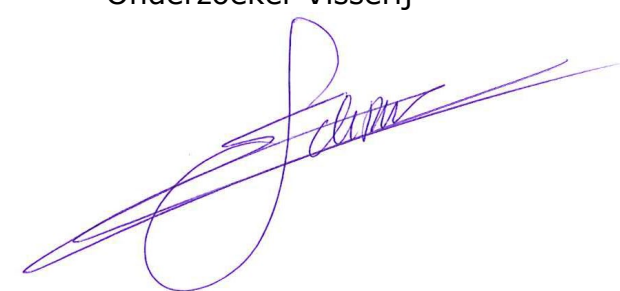

Datum:

29 mei 2019

Akkoord:

Drs. J. Asjes

MT lid Integratie

Handtekening:

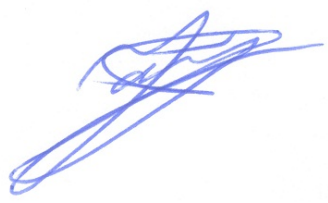

Datum:

29 mei 2019 


\title{
Bijlage 1: Verslag bemonsteringsreis eBRP
}

\author{
Vaartuig: TX-36
}

Reisduur: 22 t.e.m. 27 oktober 2017

Aantal slepen: 33 slepen uitgevoerd, 27 slepen aanwezig voor analyse, 20 effectief bemonsterd Opstappers: Maarten Soetaert (ILVO, bemonstering) en Harmen Klein Wolthuis (HFK Engineering, technische aanpassingen)

De TX36 'Jan van Toon' voer zondagavond omstreeks $22 \mathrm{u}$ uit en was vrijdagochtend vroeg terug in de haven. De TX36 vist met pulswing en broeknetten (Figuur 1) waarbij beide broeknetten aan bakboord initieel voorzien waren van een eBRP. Omwille van de beheersbaarheid van de hoeveelheden vangst en het kleine verschil in visnamigheid tussen het stuurboord- en bakboordnet in de weken voorafgaand aan deze observerreis werd er besloten om de vergelijking te maken tussen de binnen- en buitenkuil van het bakboordnet. Hiertoe werden beide kuilen afzonderlijk opgevangen in de stortbak d.m.v. een tussenschot (Figuur 2). Indien het weer het toeliet werden beide kuilen ook afzonderlijk gewogen met de unster van CIV Texel, anders werd een inschatting gemaakt van beide vangsten.

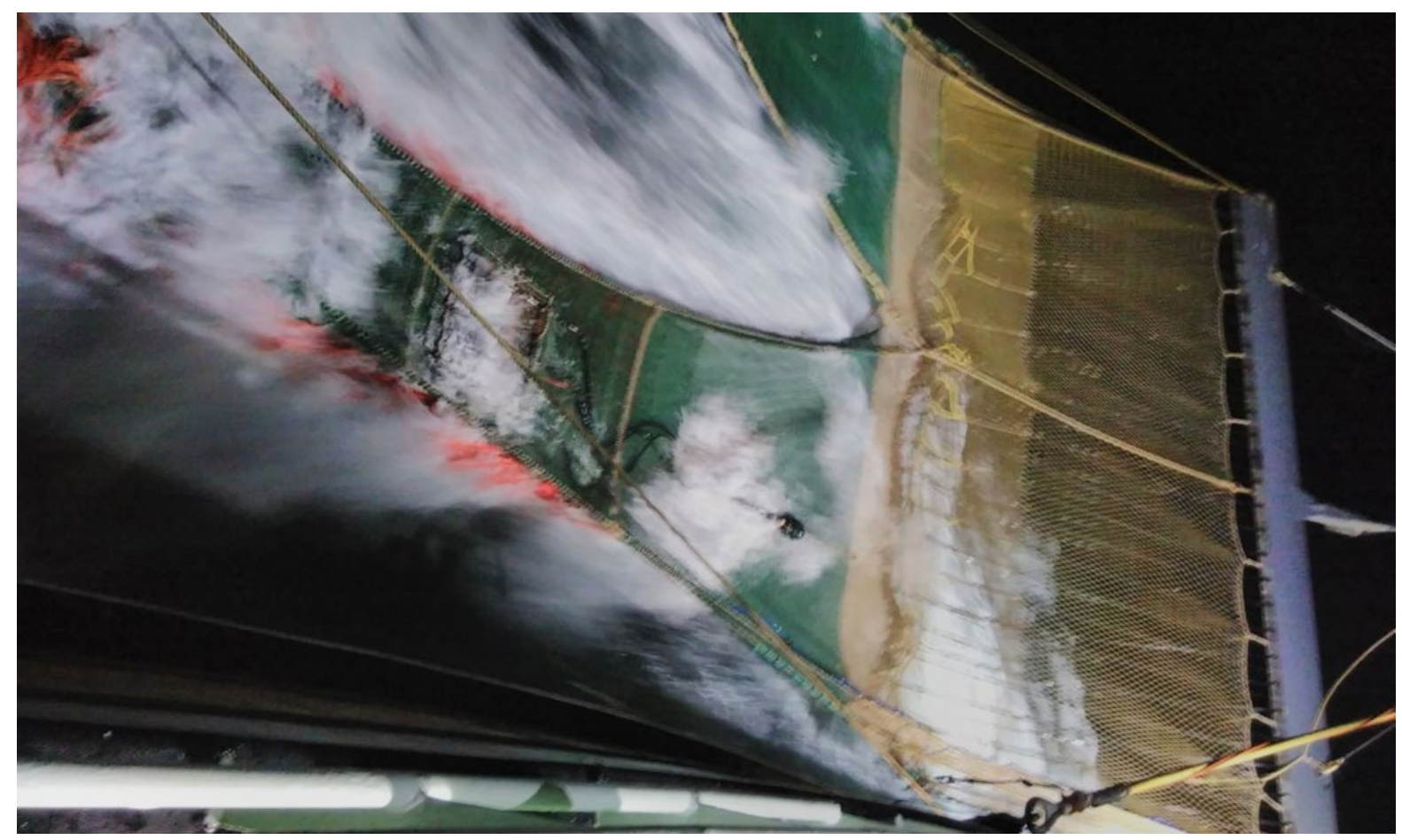

Figuur 1: Beeld van het bakboord vistuig tijdens het spoelen van de netten op het einde van de reis. Aan de binnenzijde is duidelijk de puls uitrusting en 3 elektrodes te zien, alsook het paneel in de rug dat voor de laatste sleep geopend werd.

Voor de vangstanalyse werden alle commerciële tongen apart gehouden door de bemanning. De totale vangst per zijde werd gewogen en vervolgens werden alle tongen geteld en gemeten. Indien de gewichten van de beide kuils betrouwbaar waren, werden ook de discards geanalyseerd. Voor de analyse van de discards werd afwisselend van beide sorteerbanden stalen genomen met een emmer die uitgestort werden in een vismand zodat een zo homogeen mogelijk substaal van de discards verkregen werd. De mand discards werd gewogen en gesorteerd waarbij enerzijds tong, schol, schar, kabeljauw, wijting, steenbolk, rog afzonderlijk gewogen werden en anderzijds het gewicht van resterende vis (hondshaai, poon, mul...) en restfractie (benthos en stenen werd bepaald. Echter, de hoeveelheden discards van ondermaatse tong, schol en rondvis waren gedurende de hele reis gering. 


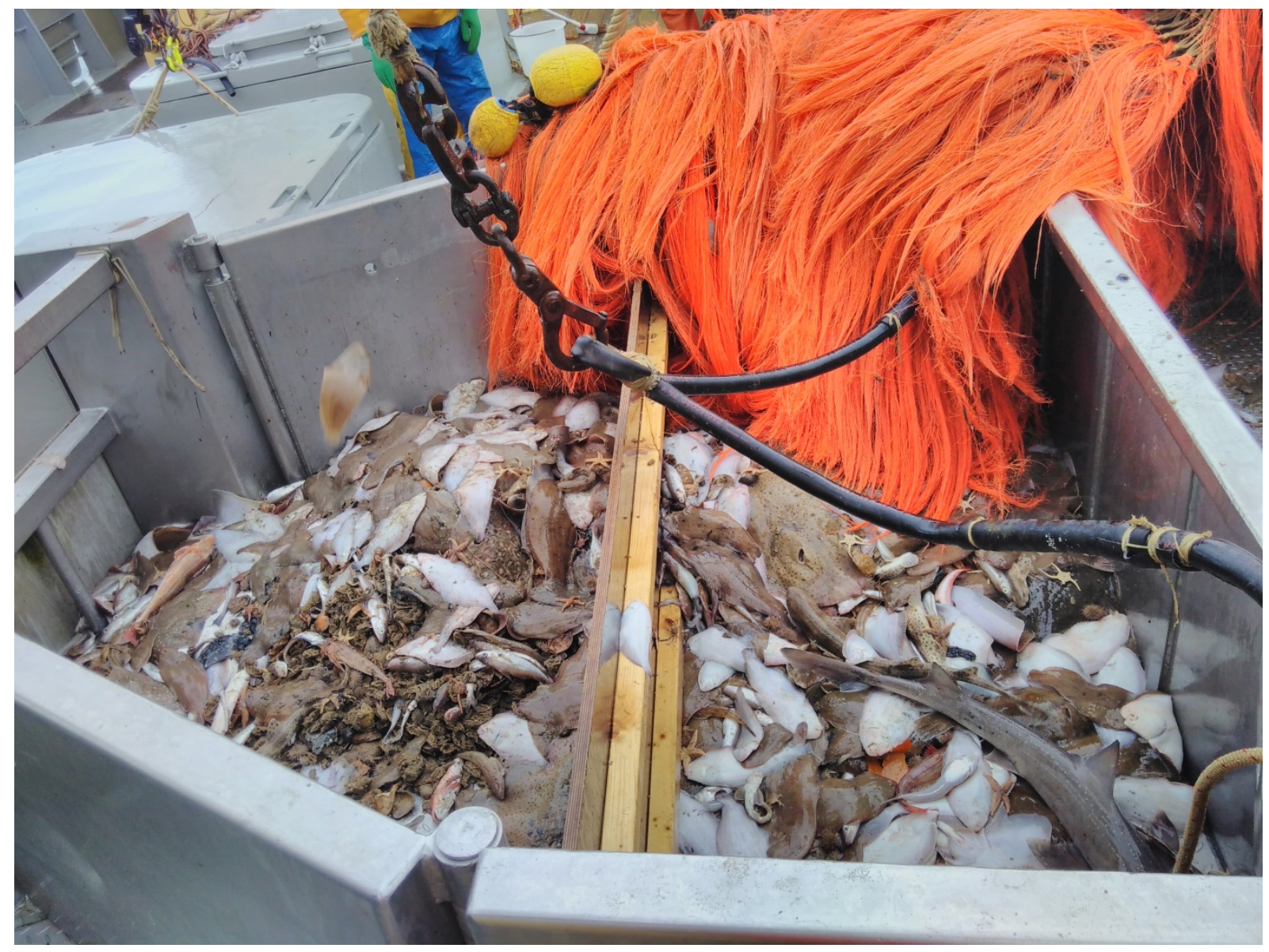

Figuur 2: Foto van het tussenschot gebruikt om de vangsten uit de kuilen van het binnenste en buitenste net van de pulswing aan bakboord gescheiden te houden.

De eerste dag werden nulslepen uitgevoerd waarbij het hele paneel behalve de achterste maas gesloten bleef. Deze dag verliep probleemloos 5 slepen ('nulslepen') werden succesvol bemonsterd en toonden aan dat het binnen- en buitennet gelijk vingen en ook de vangsten van commerciële tong nagenoeg gelijk waren. Daarom werd de ochtend van dag 2 het paneel aan de binnenkant volledig opengemaakt zodat er vergelijkend kon worden gevist tussen het binnennet aan bakboordzijde met open eBRP en het buitennet aan bakboordzijde zonder open paneel in de buik maar met dezelfde pulsende elektrodes in de buik van het net ('eBRP - stabiele puls'). Dit ging goed tot bij het halen de pulskabel naar het eBRP bij het halen van de 3e sleep (sleep 12) bleef hangen en losgerukt werd. Aangezien de pulssysteem voor het eBRP hierdoor onbruikbaar was geworden, besliste Harmen om alle eBRP-elektronica uit het buitennet te snijden en die te gebruiken om tot 1 goed werkend systeem voor het binnennet te komen. De werkzaamheden aan boord veroorzaakten een uur uur visverlet. Het paneel in de binnenkant van het bakboordnet werd opnieuw toegemaakt zodat er in afwachting van de reparatie extra nulmetingen konden worden uitgevoerd. Op die manier werden opnieuw 4 slepen geanalyseerd, al was het weer te ruw om betrouwbare gewichtsmetingen te doen waardoor enkel de hoeveelheden en lengte van de maatste tong bepaald werd.

Rond de woensdagmiddag was de elektronica hersteld en werd deze in het binnennet bevestigd wat opnieuw een dik uur visverlet betekende. Het bijhorende paneel werd opnieuw opengemaakt zodat opnieuw vergelijkend kon worden gevist, al had het buitennet ditmaal geen puls in het net. Bovendien traden er ook problemen op met de software waardoor de puls op het eBRP instabiel was en regelmatig wegviel. In deze configuratie ('eBRP - niet stabiele puls') werden in totaal 6 trekken bemonsterd. De verschillen in vangstvolume waren beperkt maar er werd geen tong verloren. Donderdag omstreeks de middag vond Harmen een oplossing voor het software probleem waardoor de puls op het paneel weer ononderbroken en stabiel werkte en nog 2 extra slepen konden worden uitgevoerd. In totaal werden tijdens de 5 slepen in deze beoogde configuratie ('eBRP - stabiele puls') een kleine meervangst aan tong vastgesteld in het net met eBRP en een klein verlies aan box. De allerlaatste sleep werd er nog een extraatje getest. Boven het eBRP in het binnennet werd een identiek paneel in de rug gestoken om te testen of hiermee rondvis kon 
worden geloosd. Alle gediscarde rondvis werd geteld en er werd een klein verlies (15\%) aan van rondvis opgemerkt voor het net met eBRP + paneel in de rug. Jammer genoeg werden bij het legen van de beide kuils aan bakboord een deel van de tongen aan de verkeerde kant gegooid waardoor we geen zicht kregen op mogelijke verschillen hierin. Aangezien er tijdens de reis echter af en toe tongen gekopt zaten boven het eBRP, kan vermoed worden dat een deel van de tong door het paneel zou ontsnappen. Daarom lijkt het aangewezen om in de toekomst het paneel in de rug voor het eBRP te steken.

Op het einde van de reis werden de maaswijdtes van de kuilen bepaald door de bemanning. De kuil van het binnenste net aan bakboordzijde, het net uitgerust met het eBRP, had een gemiddelde maaswijdte van $81.2 \mathrm{~mm}$ terwijl dit bij het buitenste net waarmee de vergelijking gemaakt werd $81.9 \mathrm{~mm}$ bedroeg. 


\title{
Bijlage 2: Touwtjespaneel
}

\author{
Verslag touwtjes paneel
}

Jaap van der Vis TX36

Hierbij kort een beschrijving van wat we gedaan hebben en wat onze bevindingen zijn.

$\mathrm{Er}$ is een paneel gemaakt van stukken netwerk van ongeveer $50 \mathrm{~cm}$ en daar tussen dyneema touwen geknoopt van 1.5 meter.

De totale lengte van het paneel werd 8.5 meter.

Het paneel is aan de voorzijde van het net ongeveer 1.00 meter achter de grond pees van het net aan de onderzijde bevestigd.

Het paneel liep door tot ongeveer 1.00 meter voor de kuil en zit daar vast op de boven zijde van het net. Daar achter komt aan de boven zijde de 2 e kuil.

Aan de hand van eerdere bevindingen van collega's begrepen we dat er veel hoogte in het achternet moest zijn om de vis te scheiden.

We hebben gekozen om een soort vlieger op het achter net te plaatsen en wat grootte drijvers achteraan waar het paneel eindigde.

Vrijdag 29 juni het achternet met het sorteerpaneel aangestoken aan boord van de TX36 ( Texel)

Maandag morgen 2 juli is de Tx36 uitgezet in de buurt van botneygat.

De eerste trek zit er $75-80 \%$ van de vangst in de boven kuil.

Geen bijzonderheden te zien, De vis wil in ieder geval over de touwtjes heen.

na 2 trekken achter aan de boven zijde net 2 grote ballen er bij gezet, om wat meer lift te krijgen. Dit gaf niet beter resultaat.

De vlieger gaf zo veel opwaartse kracht dat de zee sterren de onder zijde van het net uit spoelde.

De vlieger is later van het net gehaald.( zie data overzicht)

De resultaten blijven ongeveer hetzelfde, ongeveer 60-70\% vis boven en $30-50 \%$ boven.

$\mathrm{Er}$ is in de week nog geprobeerd met hier en daar wat ballen onder het sorteer paneel.

Dat maakte weinig verschil in resultaat.

Alleen toen we 2 grote ballen ( 11 liter) on 3/4 lengte onder het paneel bevestigde zat bijna alle vis in de onder kuil.

Donderdag besloten in overleg om vrijdag 6 juli het achter net weer te wisselen voor origineel.

Dit om kosten te besparen in vangst verlies en rustig te evalueren hoe nu verder.

De indruk van Jaap (Schipper TX-36 ) is dat we hier zeker verder mee kunnen.

Jaap was verrast hoe de schol en ook zeesterren keurig over de touwtjes naar achter gingen in de boven kuil.

Nu nog de truc, hoe krijgen we meer tong onderin ( dus door het sorteer paneel)

Maandag 9 juli overleg gehad in de loods op Texel met Jaap, Cees en ik zelf.

We komen tot de conclusie dat het zeker werkt, maar meer lengte nodig hebben zodat de tong meer gelegenheid heeft om onder het paneel te komen.

84 van 160 | Wageningen Marine Research rapport C051/19 
Met een vis snelheid van 4.4 knopen en een paneel van 8 meter wat bijna direct achter de midden vast zit is het nog best knap dat er al $50 \%$ tong onderin zit.

Maar omdat de TX-36 mist met 2 korte achter-netten aan 1 tuig kunnen we hier niet een langer paneel in maken.

Dus eigenlijk zouden we dan naar 1 enkel achternet moeten wat een stuk meer lengte geeft.

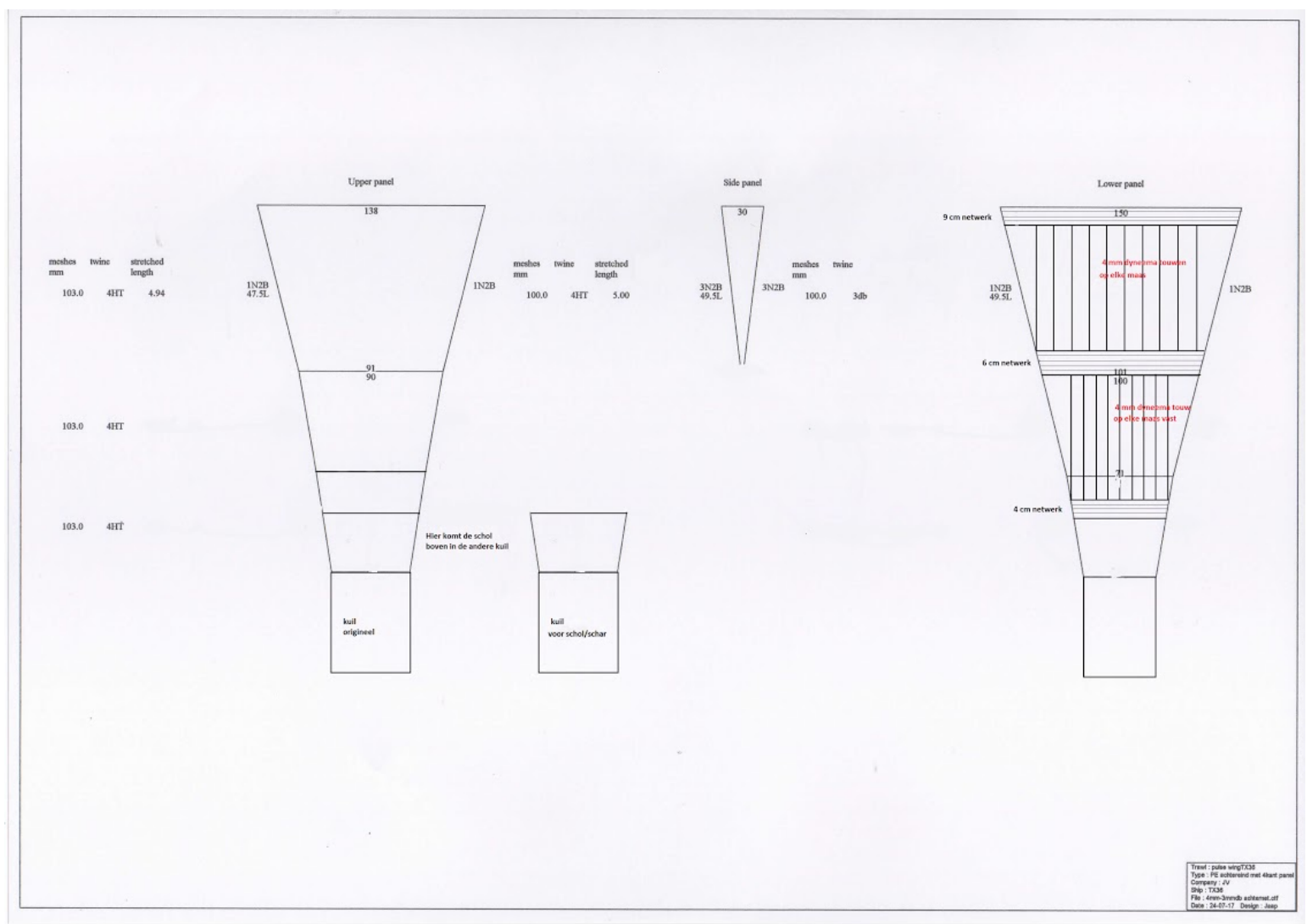

Figuur Nettekening touwtjespaneel 


\section{Verslagen verlengt touwtjes paneel}

\section{Verslag van tong scheidingspaneel TX36-week 51-52}

Week 51 naar zee gegaan met aan BB een enkel achternet.

Daarin zit een scheidingspaneel van bijna 17.5 meter.

Het scheidings paneel beging ongeveer 1 meter achter de rubber onder pees en loopt tot 50 $\mathrm{cm}$ voor de zak.

Daar komt de vis wat boven het paneel zit in een aparte kuil.

Hoe ziet het paneel eruit?

Zie tekening bijlage.

Er zitten 2 kleine vliegers net voor de kuil op de bovenzijde van het net bevestigd.

Dit om wat hoogte te creëren in de tunnel en ook als probeersel om de kuil te lichten.

Zodat er minder pluis op de kuil nodig is.

$\mathrm{Na} 2$ trekken er is de voorste vlieger eraf gehaald er leken wat stekers te zitten in de boven zijde. $\mathrm{Na}$ het weg halen gaan verschil in vangst. Wel geen stekers meer.

Er komt ongeveer $50 \%$ tong onder en $50 \%$ boven.

Wel gaat er veel vis boven het scheidings paneel langs in de boven kuil.

$\mathrm{Na}$ een aantal trekken zijn er om en om touwtjes weg gesneden uit het paneel.

Nu leek het iets beter met de tong onderin.

Er blijft nog steeds veel tong ook boven in komen.

Wel $70-80 \%$ vis zit boven in.

Toen na 2 etmaal werd er een heel grote steen gevangen en die bleef boven de scheidings flap liggen. Dit veroorzaakte schade aan het net.

Het was toen ook flink brieserig weer.

Besloten is toen om de week uit vissen zonder nog meer veranderingen te doen aan het paneel.

Om dat dat erg lastig is aan boord, en om zo weinig mogelijk vangst verlies te krijgen in de besomming

Dus toen is de week uitgevist op deze manier.

\section{Week 52:}

We moesten iets verzinnen om de tong meer in de onderkuil te krijgen.

De voorkant van de scheidings flap zat vast gemaakt op de onderzijde van het net 1 meter achter de rubber pees.

Nu kozen we er voor om de scheidings lap los te maken van de onderzijde net.

En met touw te verbinden aan de boven kant van de rubber pees op de trek ontlasters.

Dan zou de tong( theoretisch )achter de midden al onder het paneel kunnen.

Zie foto. 


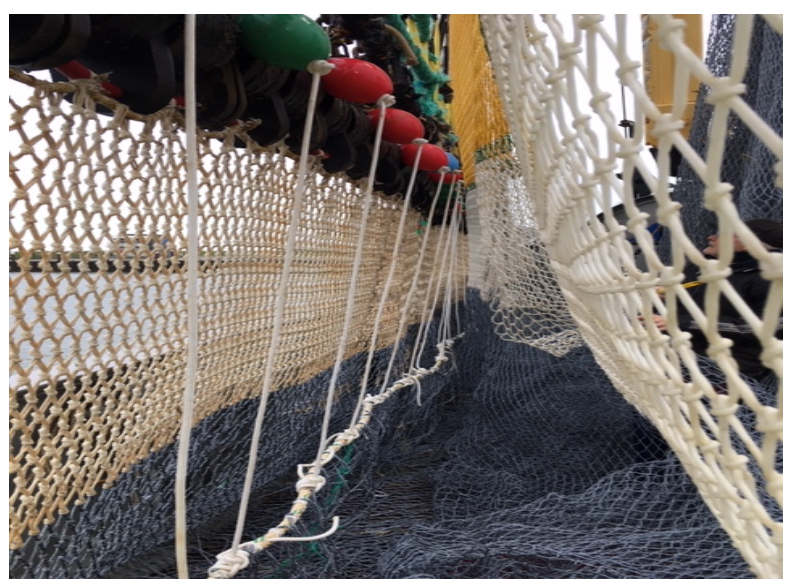

Voor de rest weinig veranderd aan het paneel.

De eerste trek zat er weer veel vis boven in.

$3 \mathrm{~kg}$ tong onderin en $9 \mathrm{~kg}$ boven in.

Bentos half om half.

Er kwam zelfs een steen van 60 kilo in de bovenkuil terecht.

Het leek dat de vlieger voor de zak er toch nog te veel aan trok.

Deze is na aantal trekken verwijderd.

Daarna nog iets meer vis en tong boven in.

We komen erachter dat de scheidings lap toch iets te strak staat.

We overleggen om de lap vooraan op te vieren of er achteraan $20 \mathrm{~cm}$ wijden vierkante mazen tussen te zetten.

Het laatste word gedaan.

De trekken daarna zit er meer tong onderin en ook de de bentos weer onderin de kuil.

Daarna worden er nog om en om meer touwtjes weg gesneden uit de lap.

Hierna weer iets meer tong onderin, vis zelfde bovenin.

De tong blijft 50-50 procent onder en boven in gemiddeld. De vis wil wel erg goed in de boven kuil. Zelfs zo veel vis dat Jaap bang is soms of dat lichte kuiltje het wel houd.

Hierna zijn er weinig veranderingen meer toegepast.

Willem ment doet keurig zijn monsteringen.

Onze conclusie:

- De tong duikt en gaat niet zo vaak liggen als beweerd werd.

- Het is heel erg lastig om tong en schol te scheiden.

Hoe verder:

- Er zou nog geëxperimenteerd kunnen worden om nog meer touwtjes weg te laten en de mazen nog wijder open te zetten om de tong makkelijker door het paneel te kunnen laten gaan.

- We denken anderzijds dat zon lang paneel niet echt noodzakelijk is.

- Meer achterin het net de tong en schol scheiden op hoogte en gebruik maken van de zuigende werking van de bovenkuil. 
Verslag van project TX36 lang sorteer paneel.

JV Visserijconsultant

Jaap Vlaming

Noordvlak 12

1791 SG

Den Burg

Scheveningen 04-01-2019

\section{VERSLAG BEMONSTERINGSREIS TX-36 IN WEEK 52}

Vaartuig:

Reisduur:

Haven:

Aantal trekken:

Aantal trekken bemonsterd:

Weersomstandigheden:

\author{
TX-36 'Jan van Toon' \\ 26/12 21.30 uur - 30/02 17.45 uur \\ Vertrek Oudeschild (Texel) - aankomst Den Helder \\ 29 \\ 19 \\ Donderdag; ZZW 3 \\ Vrijdag; $\quad$ ZW 4 \\ Zaterdag; $\quad$ ZW 4 ('s avonds een paar uur W $7-8$ ) \\ Zondag; $\quad$ WZW 3 - 4
}

Op zondagavond 26 december voor vertrek met schipper Jaap van der Vis en netspecialist Jaap Vlaming het protocol doorgenomen en van Jaap Vlaming de invulsheets in ontvangst genomen. Rond 21.30 uur vertrokken en op donderdagochtend om 07.15 uur uitgezet op ongeveer $54^{\circ} \mathrm{N}$ en $003^{\circ} \mathrm{O}$. Echter vanwege een storing bleek er geen spanning op beide tuigen te zijn. Na advies van de wal kon ongeveer een uur later daadwerkelijk gevist worden.

Bemanning aan boord: Jaap van der Vis (schipper), Piet Zandee, Tijmen Wit, Rick Koning, Luke Zijlstra en Corné van Heerwaarden.

Donderdag tot en met zaterdagochtend goed visweer. Zaterdagmiddag en -avond een aantrekkende wind die na middernacht weer afnam. Bij het verwerken van de monstername (nummer 17) van trek 24 was het bijzonder lastig om alles nauwkeurig te registreren. De handweegschaal vertoonde te veel variaties vanwege het heftig slingeren en de emmertjes moest ik met veel moeite bij elkaar houden. Omdat er geen verbetering in het weer optrad, heb ik op zaterdagavond tot een paar uur na middernacht trek 25, 26 en 27 overgeslagen. Zondagochtend de bemonstering rond 04.10 uur weer opgepakt met het halen van trek 28 en daarna trek 29 (0ngeveer 06.30 uur). Na het scheepzetten van de tuigen om ongeveer 07.45 uur een aanvang gemaakt aan de thuisreis.

Tot en met trek 14 zijn twaalf trekken bemonsterd. Opmerkingen/bijzonderheden ten aanzien van de soorten die ik ben tegengekomen bij het bemonsteren, staan op de invulsheets. Focus lag vooral op tong en schol, maar zodra bepaalde soorten dominant aanwezig waren, heb ik die ook apart gehouden en gewogen. Omdat de eerste trekken niet veel vis bevatten, moest ik snel zijn om een volle emmer voor de bemonstering te pakken te krijgen. Het gewicht aan monsters varieerde aanvankelijk tussen 3,3 kg en 8,5 kg. Vanaf trek 4 nam dat toe van 6,7 tot $19 \mathrm{~kg}$. Bij de kleinere hoeveelheden heb ik zoveel mogelijk soorten in fracties gewogen. Behalve tong (kwam nauwelijks voor tussen de discards), schol en schar zijn bij de eerste 14 trekken vrijwel alle grauwe poon (gr poon op invulsheet), wijting en stekelrog (gladde rog kwam een enkele keer voor) apart geregistreerd en incidenteel pitvis (soms opvallend veel), inktvis en kathaai. 
Opvallend was dat de onderkuil meer kleine wijting, meer kleine grauwe poon en heel veel pitvisjes 'ving' dan de bovenkuil. Zeedonderpad ben ik nauwelijks tegengekomen, evenals harnasmannetjes. Opvallend was ook dat er zo nu en dan mul van kleiner dan tien centimeter tussen de vangst zat. Ondermaatse tarbot en griet heb ik nauwelijks gezien en indien wel aanwezig dan weggeschreven bij 'overige vis'. Dat geldt ook voor tongschar, een keer een schelvis, en kleine fracties kathaai en hondshaai. Rog (vooral stekelrog) was in elke monstername aanwezig (van groot tot klein).

De bovenkuil bevatte doorgaans meer vis dan de onderkuil, waardoor ik ook meer discards uit de bovenkuil kon halen om te bemonsteren. Dat is terug te zien in de totaalgewichten van de monsternames.

De hoeveelheid benthos was gemiddeld genomen gering, evenals dood materiaal. Bij benthos heb ik ook de dodemanshandjes gevoegd en losgetrokken van de stenen (immers dood materiaal). Over de gehele linie genomen geen grote hoeveelheden, dus behoorlijk schone boxen.

Bepalen inhoud stortbakken: De inhoud van de twee door een scheidingsplank 'afgebakende' stortbakken werd veelal door Piet Zandee ingeschat. Waarna het voor mij eenvoudig was om het na een paar trekken zelf te doen. Voordeel was ook dat de eerste trekken niet veel vis bevatten waardoor het makkelijk was de inhoud te schatten op basis van aantallen manden.

\section{W.M. den Heijer}

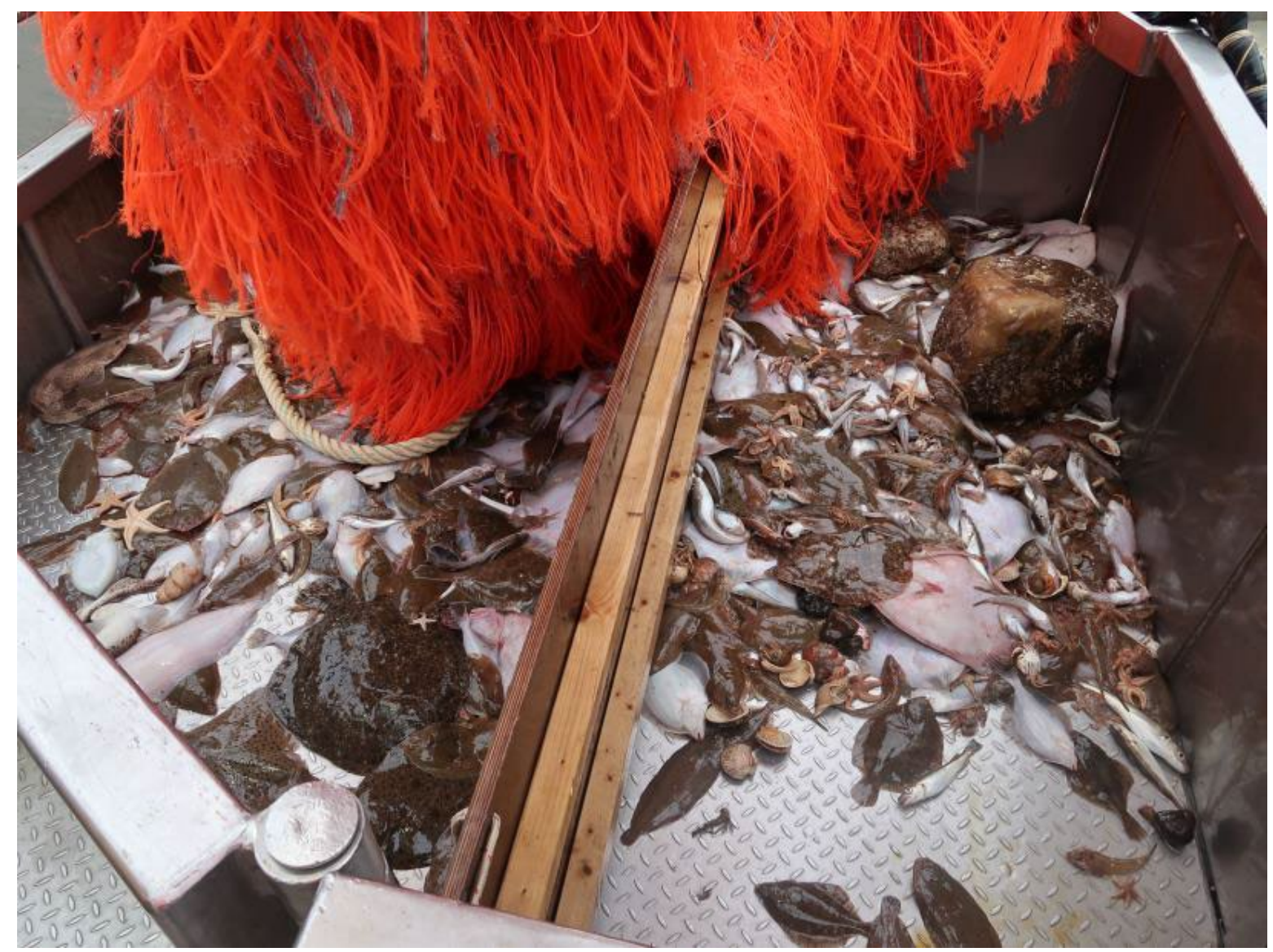




\title{
Bijlage 3: Pulse Selector
}

\author{
Verslag Pulse Selector
}

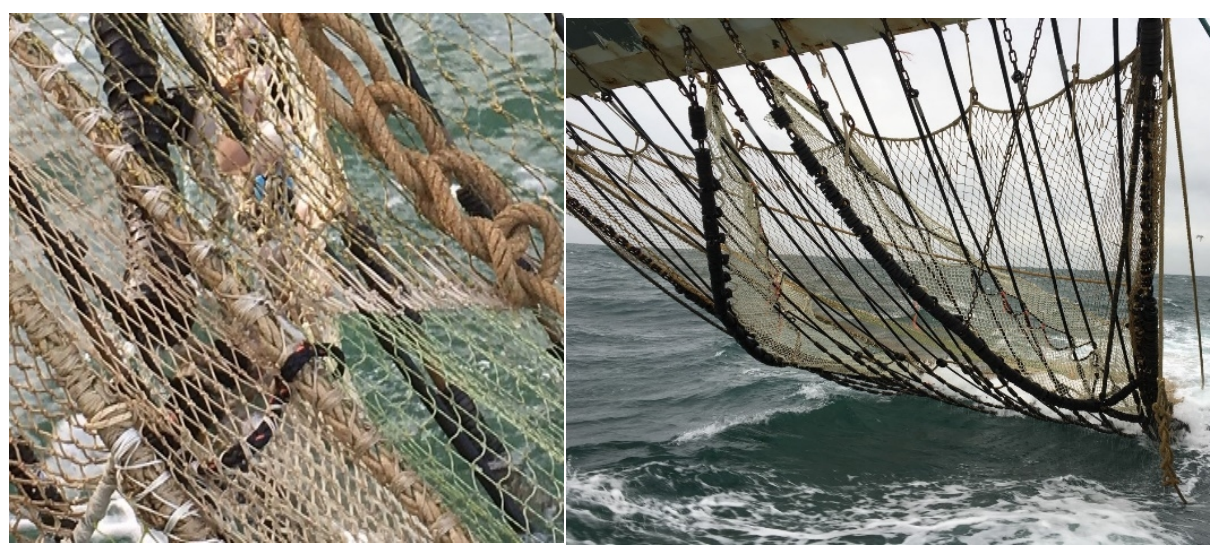

De bedoeling van de puls Selector is het scheiden van kleine platvis en tong tevens word op deze manier kabeljauw en rog om het puls Wekveld heen geleid.

Daarna is het de bedoeling om via ontsnapping roosters de kleine vis te laten ontsnappen .

Getekend en bedacht in juli 2017 . waarna ik een schaalmodel heb gemaakt samen met een goede kennis. $3 \mathrm{tm} 6$ juli we hebben hier werk aan gehad, het vleugel model tuig Sumwing heb ik in bruikleen.

Bij de presentatie van het SepNep in Scheveningen is het balletje gaan rollen, oa Pieke Molenaar vond dat mijn idee een kans verdiende om als netinnovatie project omarmt te worden.

2 oktober hebben wij afspraken gemaakt in Emmeloord om het idee in te passen in een commercieel Pulstuig, de bespreking was in het kantoor Ned vissers bond met mvr Brita Trapman, zij begeleid het gehele project, vergunningen en subsidies.

11 oktober ben ik met het schaalmodel naar de innovatie dag ABN/AMRO geweest in Amsterdam daar heb ik wat uitleg gegeven over de puls selector.

$27 \mathrm{tm} 30$ november hebben wij de scheidingspanelen gemaakt in onze netten loods samen met onze schuurbaas Hugo Slot.

$13 \mathrm{tm} 14$ december hebben we de laatste ontsnappinroosters en vlerken aan de pezen vast gemaakt.

28 en 29 december 2017 hebben wij met 5 personen de puls selector in een van de netten bra 5 gehangen.

2 januari 2018 proef gevist met bra 5 en 5 personen Dirk, Peter, Fred kraak, Jan Poelen Nan Bakker.

Van s'morgens 8 u tot s'avonds $18 \mathrm{u}$. 


\section{Het proefvissen op 02/01/2018}

We zijn s'morgens om 8 uur vertrokken uit den helder we hebben de netten rond 11 uur gezet om te kijken of het sijsteem niet teveel weerstand heeft en of er geen verschil in Commerciële vangst is .

De eerste trek op vlakke en harde grond zagen wij dat het net met innovatie SB kant ietsje trok 2 a 3 graden maar dat is redelijk na een 40 minuten trekken hebben wij de netten gehaald we zagen weinig verschil in box wel zagen we vis en zeesterren in de scheidingsvlerken .

De eerste trek zaten er aan sb (selector) 25 tongen en bb 16 tongen

Tweede trek 1,15 min SB 21 tongen en BB 22 tongen

Laatste trek 1,5 uur SB 50 tongen en BB 43 tongen .

Je kunt concluderen dat je niet minder tong vangt met een puls selector in de netten .

De bedoeling is nu er een week mee te gaan vissen en dan te kijken of er verschil in vangst optreed en hoe het gaat in moeilijkere en slappere gronden , 5 en 6 januari is er mee gevist nw van den helder het vangst verschil viel mee, maar het tuig met innovatie bleek toch wat meer weerstand te hebben dan gedacht, ook met in tij vissen ging de kotter 0,4 mijl langzamer .

We hebben besloten om het alleen met een borstel pees te gaan proberen en de vis via een scheiding paneel naar achter in het net te jagen en daar of met panelen of met een nauwe of een wijde zak (kuilen) te gaan vissen.

De volgende testen zullen we gaan doen als de borstel pezen klaar zijn ook door het besluit over de pulsvisserij loopt de verdere innovatie wat vertraging op, het zou jammer zijn als we hier zouden stranden want ik geloof er heilig in dat we met dit systeem de bijvangst van kleine niet marktwaardige vis behoorlijk kunnen reduceren . en de kabeljauw en rog discussie kunnen beëindigen omdat deze buiten het puls wekveld worden geleid.

Dirk Kraak

05.02.2018 Den helder

\section{Verslag Pulse Selector met borstelpees}

Project netinnovatie kottervisserij 2 BRA 5/7

$\mathrm{Na}$ de eerdere testen van december 2017 met de puls selector op de BRA 5 vonden wij zelf dat dit project een vervolg verdiende, we hebben daarom in Februari 2018 een schaalmodel gemaakt van een puslnet en deze met de puls selector getest in het bassin van het visserij innovatiecentrum in Stellendam dit vond plaats tijdens de Vishack op 10 maart 2018 .

We hebben tijdens een aantal runs in het testbassin het gedrag van het net en de innovatie kunnen bestuderen. Daaruit bleek dat de innovatie teveel invloed had op het net, we hebben besloten om daarom in plaats van een kettingpees met vlerken het nu eens met borstel pezen te gaan proberen.

Daar de levertijd van de borstel langer duurde dan gepland liep het testen behoorlijk vertraging op, daarom konden wij pas in december 2018 een testweek plannen .

Een tweede configuratie was om via een tunnel in het net de vis die werd gescheiden voor het wekveld (puls) naar een tweede achternet te laten gaan (zak/kuil). 
Op 18 December hebben we het innovatieve net met borstels ingehangen en zijn er diezelfde nacht mee naar zee gegaan.

We wilden een aantal dingen testen NL.

1)Verliezen we geen commerciële vis door de Borstels.

2)De Weerstand van de Borstels.

3)De invloed op het net door de Borstels en de invloed op het Wekveld (puls)

4)Word er werkelijk kleine vis opgejaagd richting de scheiding tunnel en komt deze in de tweede zak/ kuil terecht.

We hebben 12 trekken gemonitord dit in verband met de weersomstandigheden die waren namelijk niet echt gunstig om een goed beeld te krijgen van het scheiden van de discards .

De eerste trek was veelbelovend toen we toch een $20 \mathrm{~kg}$ kleine vis in de tweede kuil hadden het weer was rustig en we hadden een trek in het Gaatje van Ellen gedaan omdat daar vaak veel kleine vis zwemt rond de jaarwisseling.

De trekken daarop varieerde de bijvangst tweede kuil tussen de 15 en $10 \mathrm{~kg}$ en dat viel ons tegen vooral omdat de totale vangsten varieerden tussen de $120 / 200 \mathrm{~kg}$ dit is dan wel inclusief bentos en bodem vuil commercieel ongeveer een $80 \mathrm{~kg}$.

De pluspunten waren dat er geen verschil in commerciële vangst was ten opzichte van ons standaard net aan SB. Stuurboord.

Ook trok het net even zwaar en zagen we geen rare dingen aan de stand van het net in het water, we hadden ook geen last van de het innovatie net in de grond liep.

Het viel ons op dat de scheidingtunnel wat te strak in het net zat en dat er af en toe wat kleine vis in de bovenzijde van het net zat direct boven de scheiding tunnel, dus deze moeten we er iets ruimer in plaatsen.

Een tweede punt van aanpak zou kunnen zijn om de borstels langer te maken en toch ook van een vlerk te voorzien.

Samenvattend.

Viel het ons niet tegen het patent was makkelijk in het net te hangen, vooral een tweede keer de eerste keer is toch altijd passen en meten. We zagen geen verschil in commerciële vangst. De weerstand die de borstels hadden viel reuze mee en ze zijn ook aardig slijtvast, het project verdient echt een vervolg, door een paar aanpassingen zou het best wel een deeloplossing kunnen zijn om de bijvangst van kleine schol en schar te verminderen .

Dirk kraak 02.01.2019 


\title{
Bijlage 4: Schans paneel
}

\author{
Scheidingspaneel testen TX-94 "Avontuur" \\ November/december 2018
}

\section{Project Netinnovatie II}

\section{Omschrijving}

"Springschans paneel". We hebben als het ware een springschans over de puls elektrodes gemaakt van vierkant nauwmazig wand. Het paneel begint een halve meter vóór het eerste puls pijpje, zit daar bevestigd aan de trekontlasters, en loopt door tot in het net, tot ongeveer anderhalve meter voorbij de woeling (rolder).

\section{Doel}

- Kabeljauw vóór de puls elektrodes omhoog dwingen, waardoor ze niet meer met de puls elektrodes in aanraking kunnen komen, en dus hun ruggengraat niet meer breken.

- Wijting (en eventueel andere discards) over het paneel omhoog dwingen en uiteindelijk via de wijde mazen (of indien nodig een ontsnappingspaneel) in de bovenzij van het net lozen.

\section{Plan van aanpak}

We doen testen het paneel stap voor stap, elke week een paar aanpassingen meer, zo blijft het overzichtelijk welke aanpassing welk effect heb.

- Week 1:

Het paneel in hangen, met minimale extra aanpassingen. Bevestigd aan de trekontlasters, en aan de zijkanten met een paar lange bendels aan de naden. Zodoende kunnen we eerst kijken of het paneel zo heel blijft, en goed "staat", en of er geen verlies van marktwaardige vis is. Op zee kunnen we eventueel dingen aanpassen.

- Week 2:

Aanpassingen doorvoeren naar aanleiding van de bevindingen van week 1 . Eventueel een lichte kettingpees aan de voorkant van het paneel bevestigen (dit word 1 week opgeschoven).

- Week 3:

Aanpassingen doorvoeren naar aanleiding van de bevindingen van week 2. Bevestiging aan de trekontlasters verbeteren, en een lichte grondpees vóór het paneel bevestigen.

Als alles goed lijkt te gaan is dit wellicht het moment om een ontsnappingspaneel van vierkante mazen in de bovenzij van het net, boven het paneel te maken. Dit zouden we dan aan één kant van het net doen (we vissen met een net met 2 zakken/achtereinden) zodat we vergelijken kunnen met 1 net, tussen 2 zakken.

(De realiteit leert me dat dat iets te hoog gegrepen was, en dat het proces iets trager verloopt, omdat er tijd voor gemaakt moet worden náást de normale werkzaamheden)

\section{- Week 4:}

Aanpassingen doorvoeren naar aanleiding van de bevindingen van week 3 .

Het kettingpeesie gaat er weer uit, dit geeft namelijk geen verbetering in (rondvis) discards, en veroorzaakt een tong verlies van zo'n $5 \mathrm{~kg}$ per trek.

We zullen één en ander nu op een andere manier benaderen, het moet zo bevestigd worden aan de trekontlasters dat het paneel wat hoger van de grond komt. Vóór het paneel hebben we nu nog 1 puls pijpje af geblind, die zullen we nu weer laten pulsen, in de hoop dat daar de rondvis van opschrikt, en omhoog gaat. Door het paneel wat hoger, en gelijk iets meer naar achteren te bevestigen, hopen we dat eventueel opschrikkende tongen nog onder het paneel 
kunnen duiken. Hoe de kabeljauw hier op reageert is afwachten. Eerste prioriteit is vangst van maatse vis gelijk houden, en discards lozen.

\section{Verdere ideeën / mogelijkheden}

- Aan het paneel een scheidingspaneel bevestigen wat helemaal door het achtereind naar achteren loopt en waar aan het eind een extra zak bevestigd zit, zodat de vangsten van onder en boven het paneel gescheiden worden. Dan is het idee dat de tongen in de onderste zak komen, en de overige vis in de bovenste. Die bovenste zak zou dan uiteindelijk van wijdere mazen gemaakt kunnen worden om daar de discards te lozen.

\section{Week 45}

Begonnen met het maken van het paneel (netwerk is na 14 weken eindelijk binnen)

2 uur reken en teken werk

6 uur boetwerk

\section{Week 47}

Vrijdag 16 november scheidingspaneel in het stuurboord net gehangen. Vrij simpel, de zijkanten niet langs de vlerken gestoken, maar met een paar lange bendels bevestigd. Het doel is om eerst eens te kijken of het niet snel beschadigd, en hoe het staat tijdens het vissen, en of de vangst van maatse vis gelijk is aan het bakboord net.

4 uur boetwerk

Testweek 1: Scheidingspaneel testen, zonder ontsnappingspaneel in het Stuurboord net.

Bemanning: Koos, Henk, Jeroen, Przemek, Daan.

\section{Zondag 18-11-2018}

21.00 varen vanuit Oudeschild.

Maandag 19-11 om 03.00 begonnen te vissen bij de Bruine Bank (45 mijl uit de kust van Petten). Rotweer, windkracht 6 uit het noordoosten, eind van de dag 7/8, tot woensdagmiddag aan toe.

- Doel 1 is gehaald, het paneel blijft heel, en lijkt best mooi te staan. In de haven zijn wel wat kleine aanpassingen nodig, de zijkanten moeten iets verbreed worden, en kunnen dan dicht gestoken worden langs de vlerk.

- Snel duidelijk dat er op deze manier méér (!!) kleine rondvis discards (wijting, poon, pitvisjes) en kleine krabbetjes met dit net gevangen worden.

- Het SB net vangt ook zo'n 20\% minder tongen dan BB. We hebben wat dingen aan de zaklijn veranderd, om er zeker van te zijn dat daar het probleem niet in zit, maar dat blijkt niet het geval. Vermoedelijk komt het paneel niet genoeg omhoog, waardoor de tongen na het opspringen van de puls stootjes er van onderen tegenaan zwemmen, en dan vóór de woeling al weer omlaag duiken. (Boeitjes nodig om het paneel hoger te laten staan, maar daar is het maandag eind van de dag, tot woensdag middag geen weer voor)

\section{Woensdag 21-11 15.00}

Eindelijk is het weer goed genoeg om het net aan boord te halen en wat aanpassingen te doen. We bevestigen 7 drijvers ónder het scheidingspaneel om er op die manier voor te zorgen dat het wél genoeg omhoog komt. (1 uur visverlet)

$\mathrm{Na}$ een paar trekken is duidelijk dat het probleem van de tongvangst is opgelost, de vangsten zijn gelijk aan het bakboord net. 


\section{Donderdag 22-11}

Om 21.00 zit de visweek er op, en komen we aan in de haven van Den Helder.

\section{$\underline{\text { Vrijdag 23-11 }}$}

Verdere aanpassingen gedaan, de drijvers weer onder het paneel vandaan gehaald (dat was een probeersel, maar niet voor de lange termijn). Drijvers met een paar lange touwen dóór de mazen van de bovenzij van het net, aan het paneel bevestigd. Hierdoor trekken de drijvers het paneel omhoog, en doordat de touwen van de drijvers allemaal op dezelfde hoogte door de mazen van de bovenzij gestoken zitten, trekken ze ook in één rechte lijn aan het paneel, en komt het paneel mooi omhoog zonder dat het de bovenzij van het net naar beneden wordt getrokken.

\section{Week 48}

Testweek 2: Paneel aangepast aan de bevindingen van week 1. Doel: gelijke maatse tong vangsten. Bemanning: Koos, Henk, Jeroen, Przemek, Radek, Daan, Melvin.

\section{Zondag 25-11}

We gaan om 21:00 vanuit de haven van Oudeschild naar zee. Week 2 is begonnen.

\section{Maandag 26-11}

We hebben het eerste etmaal de (maatse tong) vangsten vergeleken tussen het stuurboord en bakboord net. Daar uit bleek dat de vangsten gemiddeld genomen gelijk waren, dus dat is goed. Dat was het voornaamste doel deze week. De (rondvis) discards vangsten waren duidelijk nog niet goed. Het stuurboord net mét het paneel ving nog steeds overduidelijk meer rondvisdiscards. Echter wist ik dit van te voren, omdat er in dat opzicht niks aan het paneel veranderd was. Dat kan ook niet op zee, maar moet vrijdag in de haven gebeuren.

\section{Woensdag 28-11 / donderdag 29-11}

2 dagen met flink rotweer (windkracht 7/8 Bft uit het zuiden). Het paneel is heel gebleven, en ook deze dagen hebben we een paar trekken de tongvangsten vergeleken, en hieruit bleek dat ook tijdens het rotweer de vangsten gelijk waren, wat natuurlijk positief is.

\section{Donderdag 29-11}

Binnenkomst in Den Helder rond 21.00.

\section{Vrijdag 30-11}

Vandaag hebben we de 6 trekontlasters waar het paneel aan vast gebendeld zat vervangen, voor kortere, met langere kettingen (gelijk aan de middelste en buitenste waar het paneel al aan vast zat). Nu hebben we het paneel aan 9 trekontlasters bevestigd, met sluitingen, op precies dezelfde hoogte.

Ook hebben we een "grondpees" overdwars vóór het paneel gehangen. Die hangt net zo'n $10 \mathrm{~cm}$ vóór het paneel, en zit op dezelfde trekontlasters bevestigd. Het idee hier achter is dat de rondvis niet meer onder het paneel kan komen, doordat die grondpees ze op schrikt en omhoog doet zwemmen. De vraag is alleen of de grondpees niet te dicht op het paneel hangt, en of ie niet te veel graaft, waardoor de tongen er ook door opgeschrikt worden. Dat zullen we volgende week zien! 


\section{Week 49}

Testweek 3: Aantal trekontlasters veranderd, zodat het paneel beter bevestigd kan worden, en een grondpeesie er vóór gehangen. Tevens eerste week voor zelfbemonstering.

Bemanning: Koos, Henk, Jeroen, Przemek, Radek, Daan.

\section{Zondag 2-12}

Om 21.00 vertrokken vanuit Oudeschild.

\section{Maandag 3-12}

Schrale visserij, dus weinig vergelijk mogelijkheid. De tong vangsten van het SB net lijken iets achter te blijven. We hebben 1 trek bemonsterd, maar we vangen vandaag zo weinig wijting dat dat niet veel zin heeft. Wel vangt het SB net nog steeds overduidelijk meer (rondvis) discards.

\section{Dinsdag 4-12}

Nog steeds schrale visserij, we hebben het grondpeesie zo'n $30 \mathrm{~cm}$ meer naar voren gehangen, zodat deze wat verder vóór het paneel zit, maar dat levert nog niet het gewenste resultaat.

Tegen de avond wel een trek met aardig wat wijting, die we bemonsterd hebben. De tongvangsten van het SB net lijken wat achter te blijven, vangt elke trek zo'n $5 \mathrm{~kg}$ minder, we hebben de boel nagekeken, maar er zijn geen gaatjes of iets dergelijks te vinden, dus het moet toch door het paneel (of grondpeesie) komen. De scholvangsten zijn gelijk, maatse wijting ook, maar ondermaatse wijting is beduidend meer, en dan vooral de kleintjes, kleiner dan $20 \mathrm{~cm}$.

2 trekken later hebben we's nachts nog een trek bemonsterd, met nagenoeg het zelfde resultaat. Het verschil in ondermaatse wijting was nu zelfs nog iets groter.

\section{Woensdag 5-12}

De visserij blijft schraal, vooral de tongvangsten zijn (de hele week al) zeer slecht. Vandaag hebben we wat meer wind (windkracht 6, met een paar trekken 7) uit het zuiden / zuidwesten. We hebben nog een trek bemonsterd, maar ook nu gaf dat weer hetzelfde resultaat, $5 \mathrm{~kg}$ tong verschil, gelijke schol vangst, en veel meer kleine wijting.

\section{Donderdag 6-12}

Rond 20.00 komen we binnen in de haven van Den Helder.

We zijn tot de conclusie gekomen dat het paneel op deze manier niet het gewenste resultaat gaat opleveren. We zullen anders moeten denken. We verwijderen het kettingpeesie, die zorgt niet voor een scheiding tussen rondvis en platvis, maar we verliezen er wel tongen door (die schrikken er waarschijnlijk van op, en springen al vóór het paneel omhoog, en ontsnappen dan via de wijde mazen van de bovenzij).

We zullen het paneel nou bevestigen met langere bendels, waardoor deze iets verder naar achteren, en hoger boven de bodem komt te staan. Dan komt de vis vóór het paneel langs één pulspijpje, en krijgt daar dus al een schok, hopelijk springt de rondvis daardoor hoog genoeg om over het paneel heen te gaan, en duikt de tong die daar eventueel door opgeschrikt wordt snel genoeg weer naar beneden om onder het paneel door te gaan.

2 uur boet en stel werk

\section{Week 50}

Testweek 4: Paneel aangepast, anders bevestigd, grondpeesie weer verwijderd. 1 pulspijpje vóór het paneel. Tweede week zelfbemonstering.

Bemanning: Kees, Koos, Henk, Radek, Daan. 


\section{Zondag 09-12}

Om 21.00 varen we de haven van Oudeschild uit, voor een nieuwe visweek. Rotweer, windkracht 7 vanuit het Noordwesten met golfhoogtes rond de 3 meter.

\section{Maandag 10-12}

De eerste tekenen lijken voorzichtig positief, in de Tongvangst lijkt minder verschil tussen SB en BB te zitten. We vangen vandaag nog geen wijting en ook weinig scholdiscards, dus daar valt niks van te zeggen.

\section{Dinsdag 11-12}

We hebben vandaag 2 trekken bemonsterd, en daaruit kwam over duidelijk naar voren dat we met het paneel nog steeds (véél) meer wijting discards vangen, maar ook schol discards. De tongvangst is ook nog steeds niet gelijk, tijdens de bemonster trekken scheelde het $2 \mathrm{~kg}$, maar op andere trekken soms 5 en 10, en zolang dat niet eens een keer andersom is, is dat geen goed teken. We hebben daarom vanmiddag het paneel uit het net gehaald, omdat we niet het idee hebben er nog positieve resultaten mee te behalen. We hebben van alles geprobeerd in de afgelopen 4 weken, maar wijting lozen, zonder maatse tong te lozen gaat ' $m$ op deze manier niet worden. We zullen de week verder met 2 gelijke netten vissen, en de vangst blijven vergelijken als referentie.

We houden elke trek de tongvangst apart, en daaruit blijkt dat de netten nu gewoon gelijk vangen, soms is er verschil, maar nu ook eens andersom, zodat het gemiddeld genomen gelijk is. We zien ook duidelijk dat de box nu hetzelfde is, niet meer die grote hoeveelheden kleine krabbetjes aan Stuurboord kant.

We hebben vandaag ook nog een trek bemonsterd zonder het paneel, en daaruit blijkt dat de vangst gelijk is, dus ook van wijting (maats en ondermaats) en schol (maats en ondermaats).

\section{Woensdag 12-12}

Ter referentie hebben we vandaag nog een trek bemonsterd, en ook nu waren de vangsten wijting en schol gelijk, het stuurboord net had nu $5 \mathrm{~kg}$ tong meer, gisteren was dat andersom. 


\section{Bijlage 5: Verslag en ontwerp kiwikuil}

\section{Mod C70}

\section{Trek 1}

\begin{tabular}{cccc} 
Trek & Datum & \multicolumn{2}{c}{ Tijd } \\
$(-)$ & (dd-mm-yy) & \multicolumn{2}{c}{ (HH:MM) } \\
& & Zetten & Halen \\
1 & 15-10-18 & 03:45 & $05: 44$
\end{tabular}

Snelheid

(NM)

4.8
Diepte

(M)

33
Vislijn

(M)

133
Pos kuil

$(-)$

BB

\section{Verslag}

Uitvoering getest zoals op tekening in bijlage 1 weergegeven. Buitenkuil open. 6 stuks kleine drijvers op de bovenkant. Gemiddeld trekt de BB zijde $9 \%$ zwaarder dan SB. Zitten veel stekers in het net voor de kuil. Zit ook een enkele steker in de duct opening bovenop de kuil. Tijdens het binnen halen aan boord, scheurt de kuil open en stroomt veel water en ook vangst naast de stortbak. BB minder vangst dan SB, veel zand zelfs "droog" zand. Scheur gerepareerd door middel van boren gaten door banden en zeil, vervolgens dicht gestoken.

Vangstsamenstelling

Box totaal schatting manden $-50 \%$

Aanlandingen tong $-78 \%$

Aanlandingen schol $-56 \%$

Monsters vanaf einde opvoerband, dus ook maatse vis.

Visscore

Niet deze trek

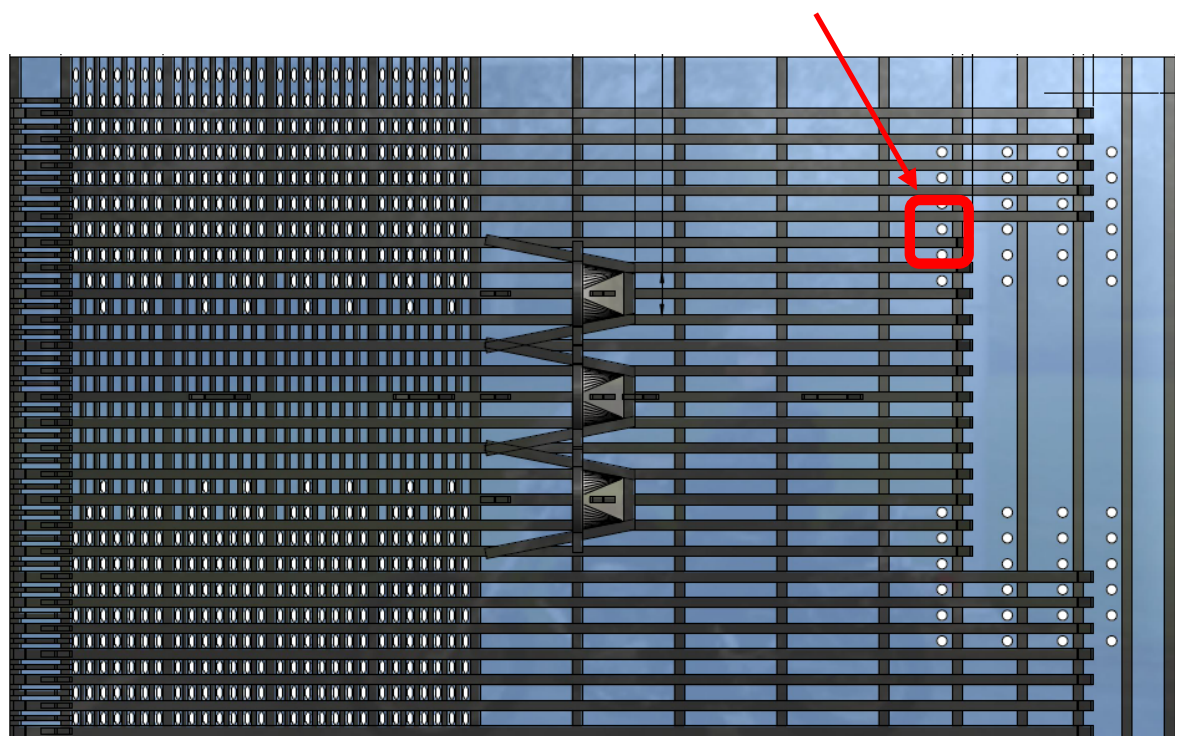




\section{Trek 2}

\begin{tabular}{|c|c|c|c|c|c|c|c|}
\hline Trek & Datum & \multicolumn{2}{|c|}{ Tijd } & Snelheid & Diepte & Vislijn & Pos kuil \\
\hline$(-)$ & (dd-mm-yy) & \multicolumn{2}{|c|}{ (HH:MM) } & (NM) & (M) & (M) & $(-)$ \\
\hline & & Zetten & Halen & & & & \\
\hline 2 & $15-10-18$ & $06: 10$ & $08: 11$ & 4.8 & 39 & 139 & BB \\
\hline
\end{tabular}

\section{Verslag}

Uitvoering getest zoals op tekening weergegeven. Buitenkuil gesloten. Gemiddeld trekt de BB zijde $15 \%$ zwaarder dan SB. Zitten meer stekers in dan $1^{\mathrm{e}}$ trek. Zit ook een enkele steker in de duct opening bovenop de kuil. BB minder vangst dan SB, BB vrij zanderig, geen droog zand. Ruim maatse vis steekt door de gaten van de kuil.

Vangstsamenstelling

Box totaal schatting manden $-58 \%$

Aanlandingen tong $-70 \%$

Aanlandingen schol $-29 \%$

Gemeten volgens protocol

Visscore

Niet deze trek 


\section{Trek 3}

\begin{tabular}{|c|c|c|c|c|c|c|c|}
\hline Trek & Datum & \multicolumn{2}{|c|}{ Tijd } & Snelheid & Diepte & Vislijn & Pos kuil \\
\hline$(-)$ & (dd-mm-yy) & \multicolumn{2}{|c|}{ (HH:MM) } & (NM) & (M) & (M) & $(-)$ \\
\hline & & Zetten & Halen & & & & \\
\hline 3 & $15-10-18$ & $08: 37$ & $10: 38$ & 4.8 & 43 & 144 & $\mathrm{BB}$ \\
\hline
\end{tabular}

Verslag

Uitvoering getest zoals op tekening weergegeven. Extra gaten gesneden ca. 80 stuks in de bovenzijde van de Kiwi kuil. Kuil heeft nu dus vrijwel rondom gaten. Bijgesneden gaten zijn echter in rechthoek tussen de banden gesneden waardoor deze waarschijnlijk niet evenveel doorstroming hebben als de bestaande gaten. Buitenkuil gesloten. Gemiddeld trekt de BB zijde 11\% zwaarder dan SB. Zitten minder stekers in dan $2^{\mathrm{e}}$ trek. BB minder vangst dan SB, BB vrij zanderig, geen droog zand.

Vangstsamenstelling

Niet deze trek

Visscore

Eerst SB gescoord, telkens 30 per kant.

Verschillen zijn gering.

BB had 53\% tegen BB 76\% meer dan 50\% huid beschadigingen.

BB had 3 dode en SB 0

Handmatig

ingesneden gaten

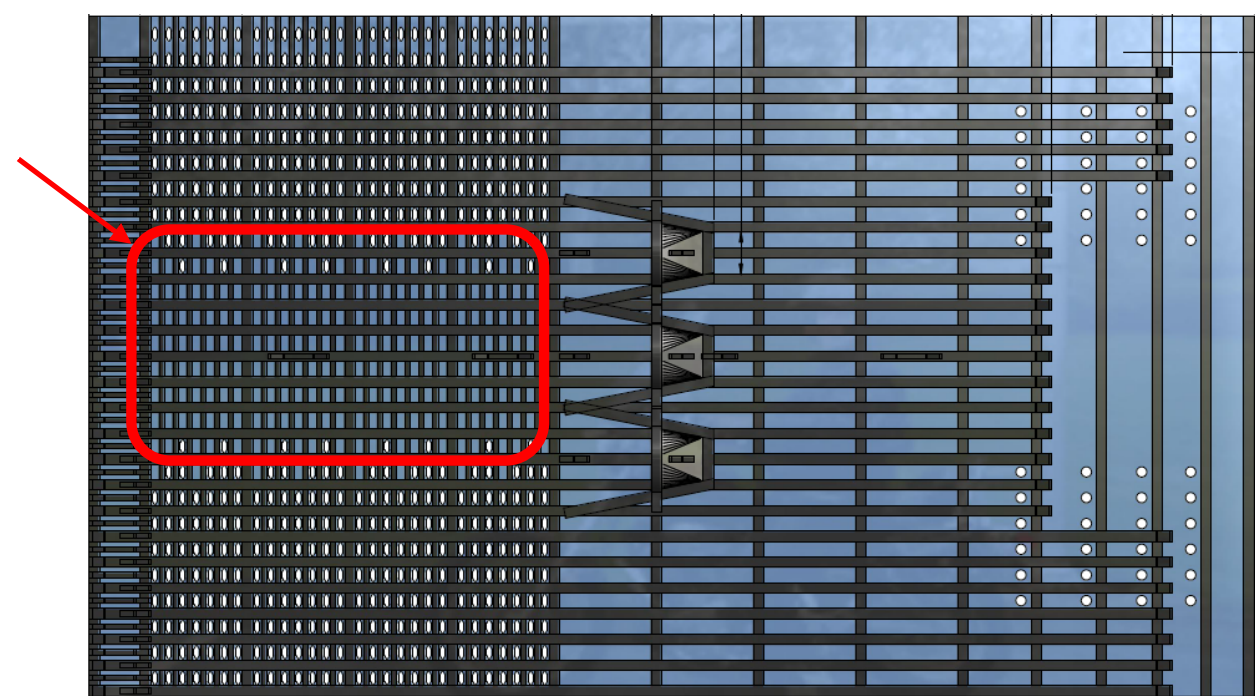




\section{Trek 4}

\begin{tabular}{|c|c|c|c|c|c|c|}
\hline Datum & & & Snelheid & Diepte & Vislijn & Pos kuil \\
\hline$(-)$ & & & (NM) & (M) & (M) & $(-)$ \\
\hline & Zetten & Halen & & & & \\
\hline $15-10-18$ & 11:01 & $13: 01$ & 4.8 & 45 & 145 & BB \\
\hline
\end{tabular}

\section{Verslag}

Uitvoering getest zoals op tekening weergegeven. Extra gaten gesneden ca. 30 stuks in de bovenzijde van de Kiwi kuil (dus totaal 110 gate). Buitenkuil gesloten. Gemiddeld trekt de BB zijde 7\% zwaarder dan SB. Zitten nog steeds stekers voor de kuil. BB minder vangst dan SB, BB vrij zanderig, geen droog zand.

Vangstsamenstelling

Box totaal schatting manden $-73 \%$

Aanlandingen tong $-66 \%$

Aanlandingen schol $-38 \%$

Gemeten volgens protocol

Visscore

Eerst BB gescoord, telkens 30 per kant.

Verschillen zijn gering.

BB had $40 \%$ tegen SB $63 \%$ kopbloedingen

BB had 3 dode en SB 3 


\section{Verbeterpunten}

Trekkracht verschil verminderen

- Tijdens elke trek is er een aanzienlijk trekkrachtverschil wat tijdens de trek ongeveer evenredig op loopt. Logisch zou zijn dat de trekkracht in het begin groter is (door weerstand van de met water gevulde kuil) en later het verschil minder word (door het vullen van de conventionele kuil met vangst).

- Probleem word waarschijnlijk door de stekers veroorzaakt. Bij grotere doorstroming door de kuil kan dit verholpen worden.

Rond elk gat moet een verstevigingsband zitten tegen uit scheuren.

- Dit was bij het huidige ontwerp al bij de meeste gaten zo uitgevoerd. Echter bij de ronde gaten achterin de kuil was dit niet het geval.

- Bij Mod D zullen deze gaten worden verstevigd met een extra verstevigingsband

Gat maat moet gewijzigd worden, bij Mod C70 steekt maatse vis door de gaten heen.

- Met Omega meter zijn verschillende zeilgaten opgemeten. De ruitvormige gaten zie bijlage 2 zorgen er voor dat het gat ca. $20 \mathrm{~mm}$ uitgerekt kan worden. Een zeilmaat van $60 \mathrm{~mm}$ kan dus nog als $80 \mathrm{~mm}$ gemeten worden.

- We hebben ook tongen in verschillende afmetingen door een maas van $80 \mathrm{~mm}$ netwerk en zeildoek van $60 \mathrm{~mm}$ getrokken. Het netwerk had 24 uur in het water zich vol gezogen en er werd een maaswijdte van $81 \mathrm{~mm}$ gemeten. Conclusie hieruit is dat er meer kracht vereist is om een tong door de maas van een net te trekken dan door $60 \mathrm{~mm}$ zeildoek.

- Bij Mod D zal een gat maat van $60 \mathrm{~mm}$ worden toegepast, bij verdere verkleining zullen er ook vrij veel gaten extra in moeten komen.

Er moet meer doorstroming in de kuil worden gerealiseerd om de vangst in de kuil te vergroten en stekers er voor te verminderen.

- Middels flowanalyses is het huidige ontwerp vergeleken met een ontwerp waar maximaal aantal gaten in zitten zie bijlage 3 . In de afbeeldingen is een sectie van de kuil door het water gesimuleerd. Het water rond de kuil stroomt met $2,5 \mathrm{~m} / \mathrm{sec}$.

- Bij intrede van Mod C word een afname van $36 \%$ berekend bij de instroom zijde

- $\quad$ Bij intrede van Mod D word een afname van $8 \%$ brekend bij de instroom zijde

- Bij Mod D zullen dus extra gaten worden toegepast. 


\section{Mod D60}

Trek 1

\begin{tabular}{|c|c|c|c|c|c|c|c|}
\hline \multirow{2}{*}{ Trek } & \multirow{2}{*}{$\begin{array}{c}\text { Datum } \\
\text { (dd-mm-yy) }\end{array}$} & \multicolumn{2}{|c|}{ Tijd } & Snelheid & Diepte & Vislijn & Pos kuil \\
\hline & & \multicolumn{2}{|c|}{ (HH:MM) } & (NM) & (M) & (M) & $(-)$ \\
\hline & & Zetten & Halen & & & & \\
\hline 1 & $11-12-18$ & $08: 52$ & $10: 59$ & 4.8 & 38 & 136 & BB \\
\hline
\end{tabular}

\section{Verslag}

Uitvoering getest zoals op tekening in bijlage 4 weergegeven. Buitenkuil gesloten. Gemiddeld trekt de BB zijde $-2 \%$ zwaarder dan SB (dus minder zwaar, verschil is nihil). Bij openen van de kuil scheuren er wat verstevigingsogen af waarmee de kuil is dicht gebonden. BB minder vangst dan SB, vangst is zanderig. Vis zag er in BB stortbak levendig uit.

Vangstsamenstelling

Box totaal schatting manden $-33 \%$

Aanlandingen tong $-47 \%$

Aanlandingen schol $-38 \%$

Gemeten volgens protocol

Visscore

Eerst SB gescoord, telkens 30 per kant.

Verschillen zijn gering.

BB had $66 \%$ tegen BB $90 \%$ meer dan $50 \%$ huid beschadigingen. 


\section{Trek 2}

\begin{tabular}{|c|c|c|c|c|c|c|c|}
\hline Trek & Datum & \multicolumn{2}{|c|}{ Tijd } & Snelheid & Diepte & Vislijn & Pos kuil \\
\hline (6) & (dd-mm-yy) & \multicolumn{2}{|c|}{ (HH:MM) } & (NM) & (M) & (M) & $(-)$ \\
\hline & & Zetten & Halen & & & & \\
\hline 2 & $11-12-18$ & $11: 18$ & $13: 22$ & 4.8 & 37 & 136 & BB \\
\hline
\end{tabular}

Verslag

Uitvoering getest zoals op tekening in bijlage 4 weergegeven. Buitenkuil gesloten. Camera en lamp in kuil bovenzijde. Gemiddeld trekt de BB zijde $2 \%$ zwaarder dan SB, verschil is nihil. Voor of tijdens het binnenhalen van de vangst is een scheur ontstaan in het zeildoek. In de stortbak word een stuk wrakhout waargenomen welke de mogelijke veroorzaker is. BB had wat zand in de kuil, alle vis was bedekt met zand, niet echt ophopingen van zand. SB had veel stenen,

Vangstsamenstelling

Box totaal schatting manden $-47 \%$

Aanlandingen tong $-54 \%$

Aanlandingen schol $-6 \%$

Gemeten volgens protocol

Visscore

Eerst BB gescoord, telkens 30 per kant.

Vissen uit BB scoorden over alle punten beter. $82 \%$ tegen $48 \%$

BB had echter wel 14 doden te betreuren tegen 8 uit SB, wellicht had zand hier invloed op.

Camera

Opname middels gopro hero 2 in bovenzijde van de kuil. Beeld onder is werkelijkheid boven. Gebruik gemaakt van ledlamp wat meer naar achter geplaats. Camera half in eerste sectie van de kuil geplaatst naar achteren kijkend. Start film is kuil net in water. Zetten word vrijwel direct ingezet en duurde deze trek exact 3 min. Kuil boven en onderzijde valt weleens op elkaar, vergelijkbaar met testen in innovatiecentrum Stellendam.
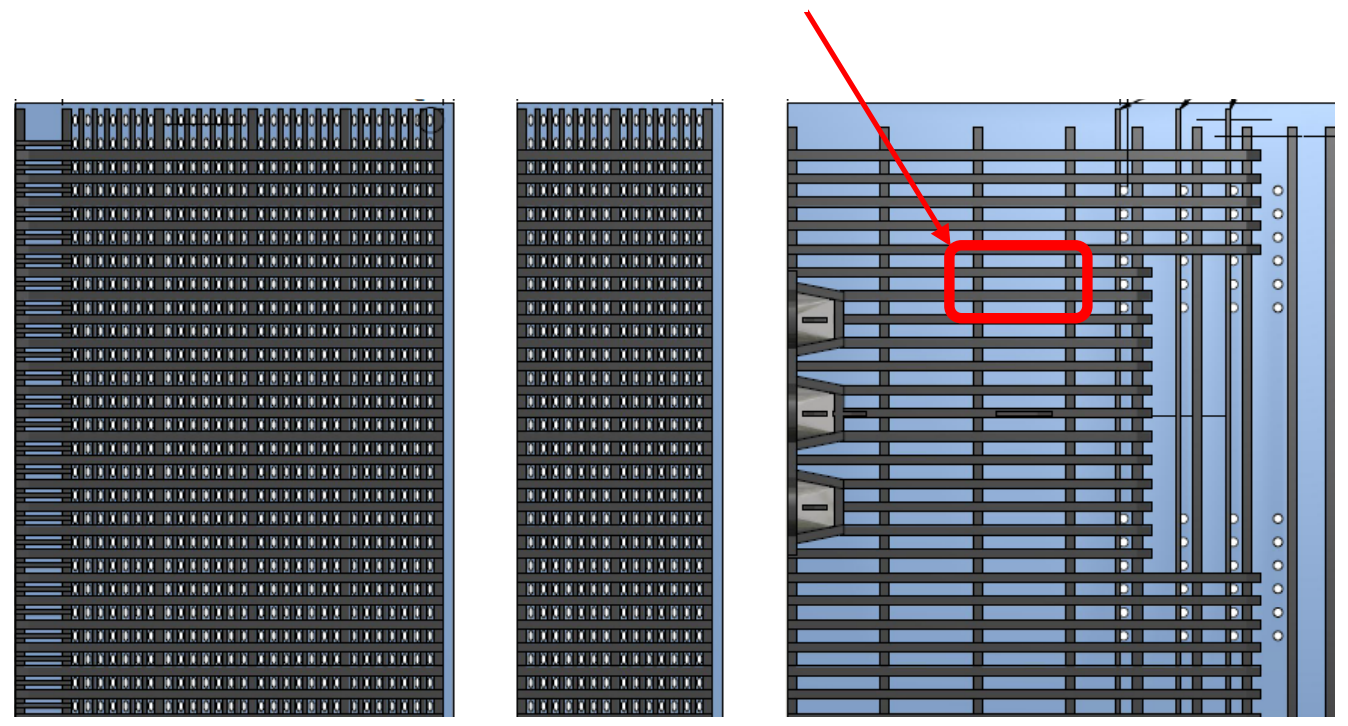


\section{Trek 3}

\begin{tabular}{|c|c|c|c|c|c|c|c|}
\hline Trek & Datum & \multicolumn{2}{|c|}{ Tijd } & Snelheid & Diepte & Vislijn & Pos kuil \\
\hline$(-)$ & (dd-mm-yy) & \multicolumn{2}{|c|}{ (HH:MM) } & (NM) & (M) & (M) & $(-)$ \\
\hline & & Zetten & Halen & & & & \\
\hline 3 & $11-12-18$ & $15: 55$ & $15: 55$ & 4.8 & 35 & 136 & BB \\
\hline
\end{tabular}

\section{Verslag}

Uitvoering getest zoals op tekening in bijlage 4 weergegeven. Buitenkuil gesloten. Gemiddeld trekt de BB zijde $2 \%$ zwaarder dan SB, verschil is nihil. BB minder vangst dan SB, vangst bevat meer zand dan trek 2 en bevat stenen.

Vangstsamenstelling

Box totaal schatting manden $-38 \%$

Aanlandingen tong $-35 \%$

Aanlandingen schol $-38 \%$

Gemeten volgens protocol

Visscore

Eerst SB gescoord, telkens 30 per kant.

Verschillen zijn gering. 


\section{Verbeterpunten}

Gat maat moet gewijzigd worden, bij Mod C70 steekt maatse vis door de gaten heen.

Er moet meer doorstroming in de kuil worden gerealiseerd om de vangst in de kuil te vergroten en stekers er voor te verminderen.

Vangen van zand moet verminderd worden. 
Bijlage verslag

Tekening mod C70

107 van 160 | Wageningen Marine Research rapport C051/19 

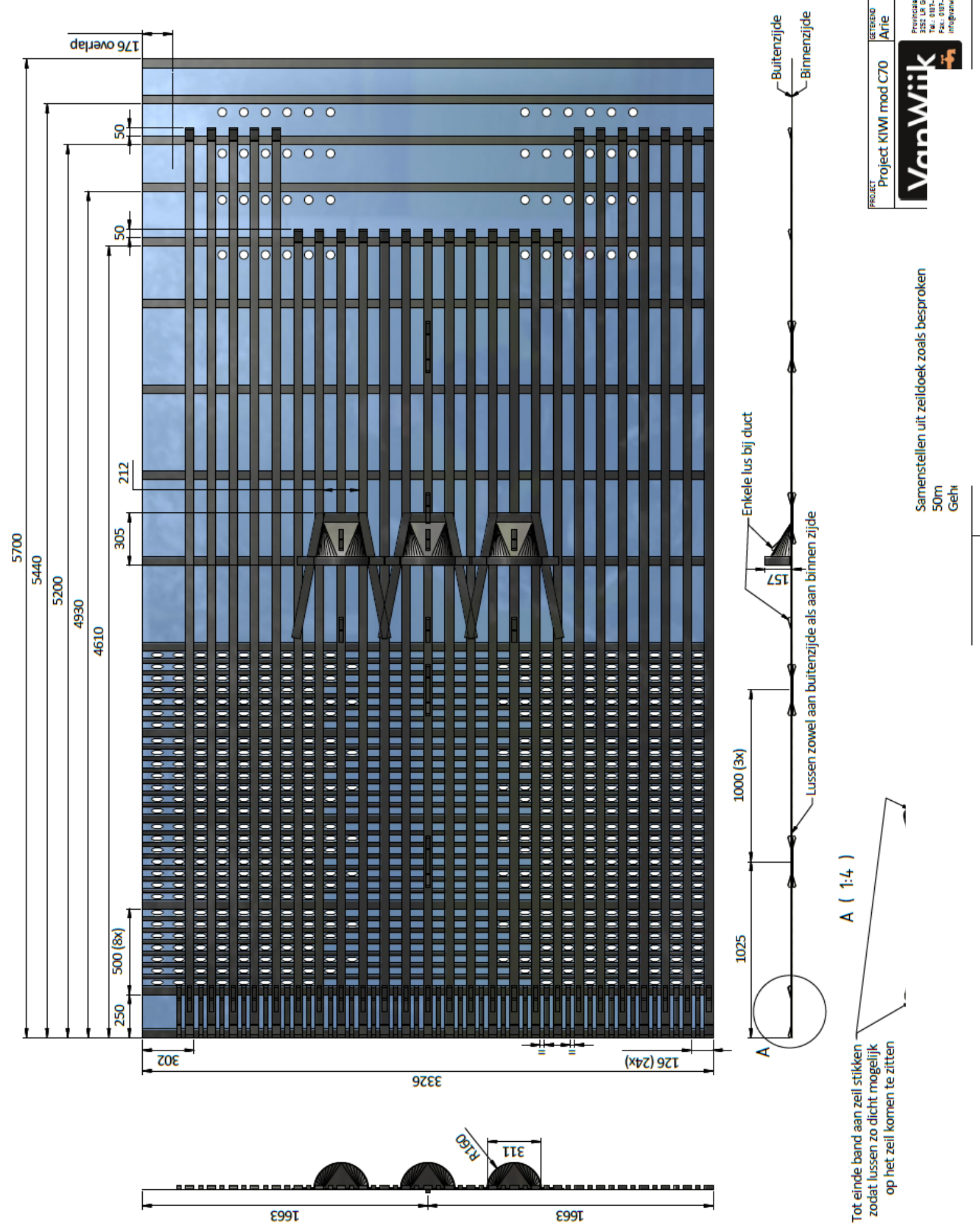
Detail zeil opening mod D70

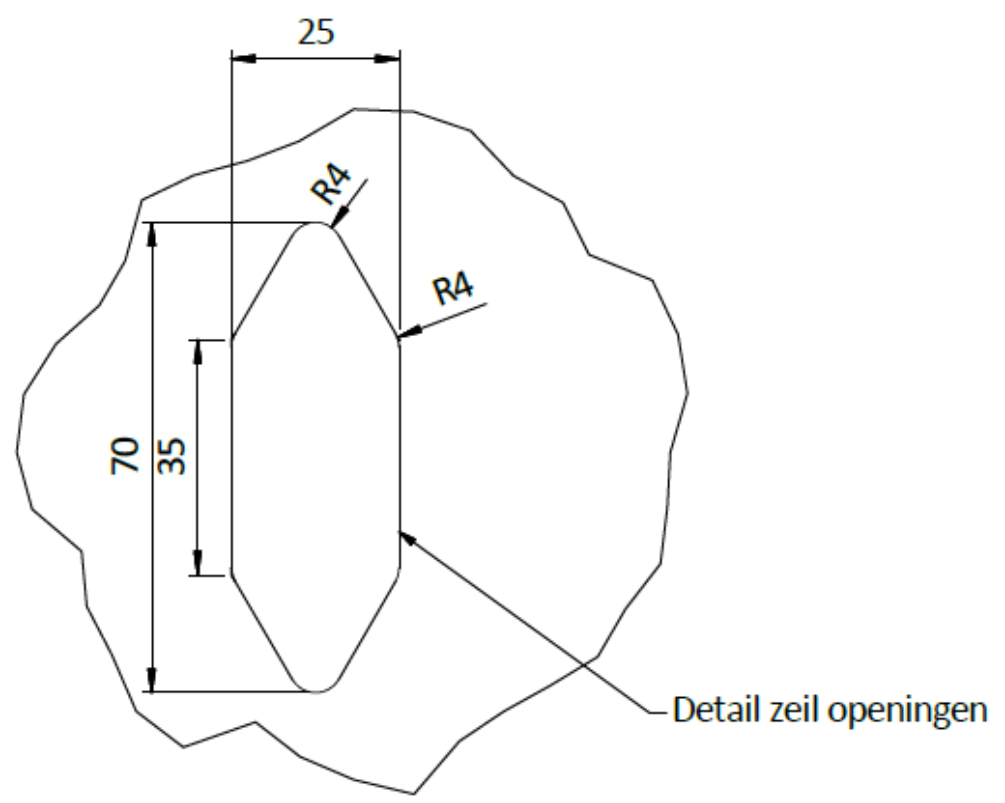




\section{CFD analyse}

Bestaande ontwerp

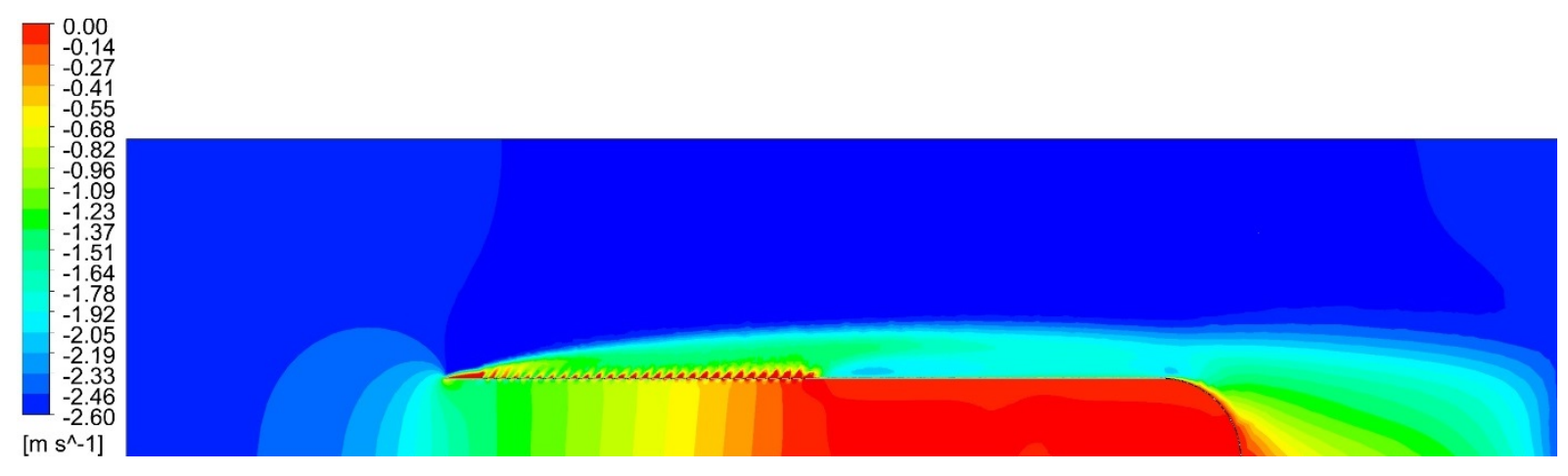

Aangepaste ontwerp

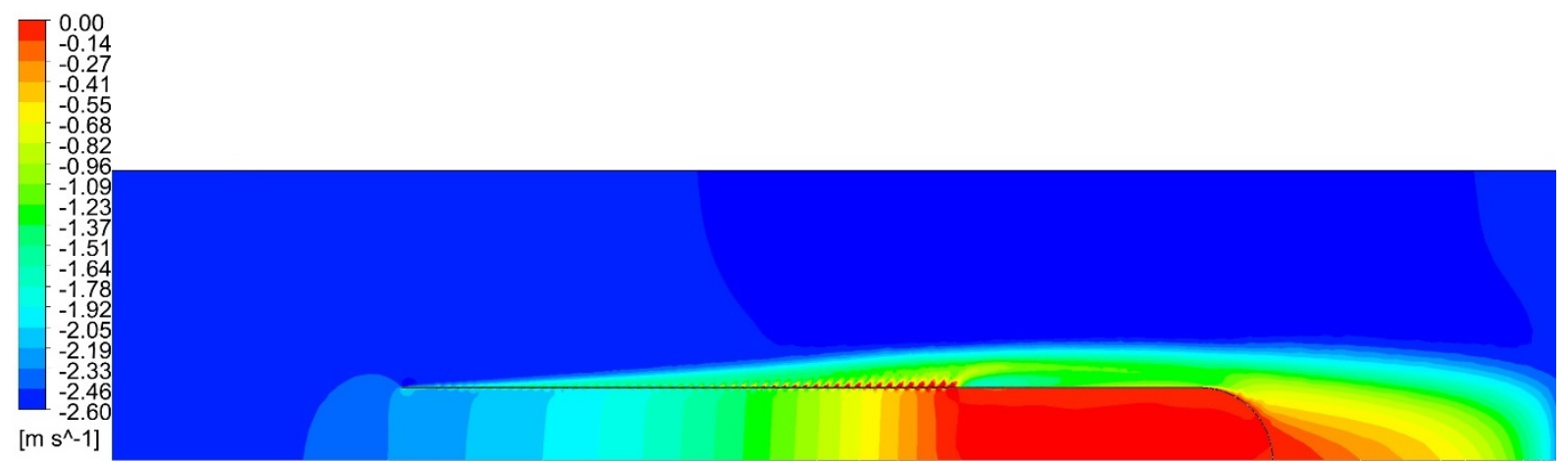


Tekening mod D60

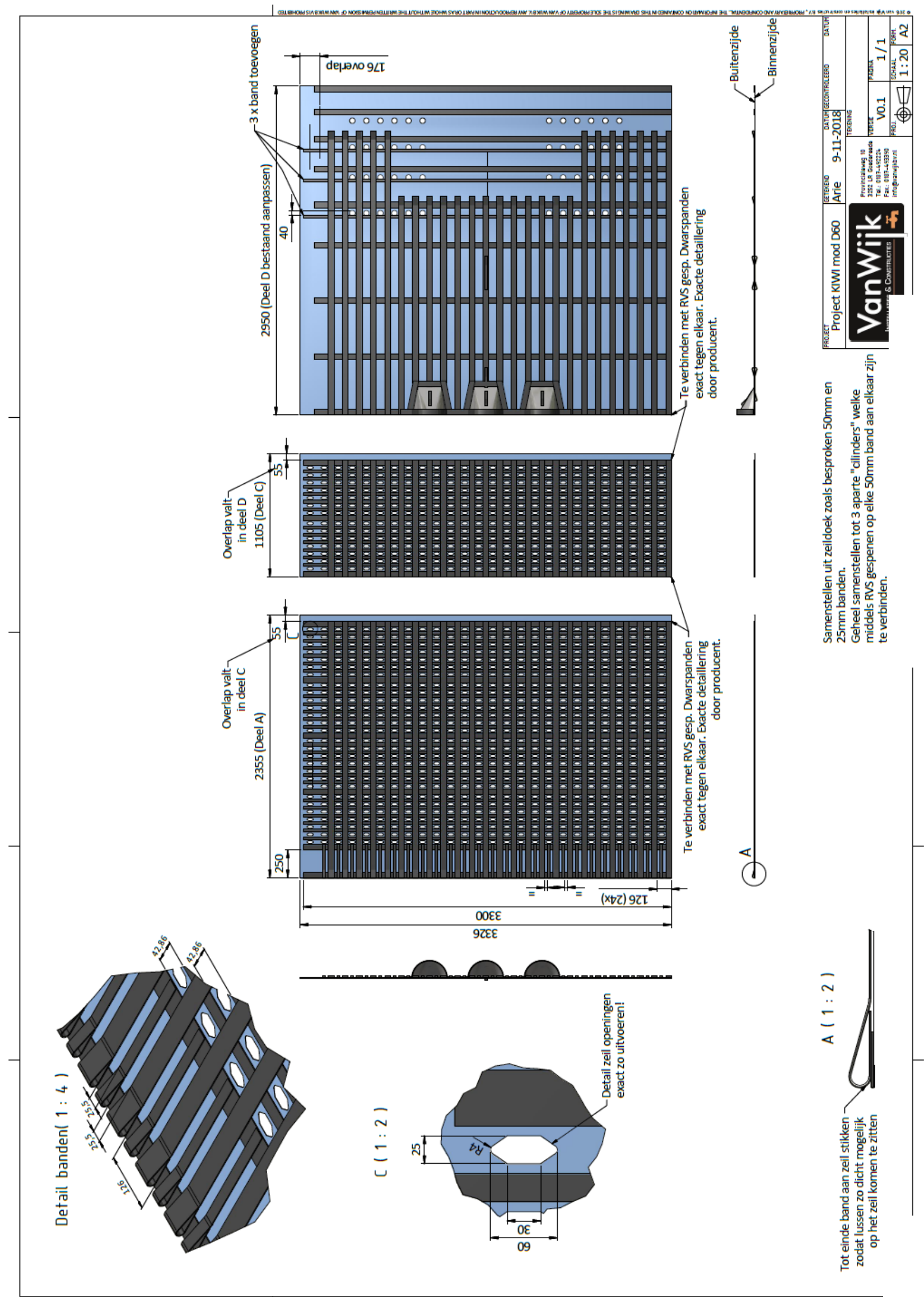

111 van 160 | Wageningen Marine Research rapport C051/19 


\title{
Bijlage 6: Ervaringen SepNep breder in de vloot
}

\section{SepNep gebruik 2017}

Auteur: Nederlandse Vissersbond

Ervaringen besproken met Brita Trapman en Durk van Tuinen (beide Nederlandse Vissersbond) en Pieke Molenaar (Wageningen Marine Research).

\section{- UK 210}

Contact gehad met Brita Trapman op 2 maart, voor dit tijd al met een versie van het SepNep gevist, wel met mazen in de bovenste kuil van $100 \mathrm{~mm}$.

Meerdere weken mee gevist: weken $7 \mathrm{t} / \mathrm{m} 9$ in ieder geval.

\section{Ervaring}

Door Jaap Vlaming gerapporteerd: Heeft foto's doorgestuurd van de vangst, heel veel schol in bovenkuilen. In de kreeftenkuil veel poon, wat schar en enkele kreeftjes. Lijkt voornamelijk op vis te vissen. Kees Bakker is van mening dat er nog wel veel vis in onderkuil zit. Heeft vorige week gevist met SepNep onder kust van Engeland, nog te veel (grote) kreeft in de bovenste zak. Rond de 10 - 30\% van de grote kreeft. Op advies van Jaap het paneel er weer uit gesneden.

\section{- $\quad \mathbf{N} 350$}

Viste in week 27 met het SepNep.

\section{Ervaring}

Om 8:00 op 18 juli 2017 stapt Brita Trapman aan boord bij de N 350, daar is schipper Meijert Smid aanwezig: 'Ik vraag hem naar zijn ervaringen met het SepNep. Hij zegt dat de ervaringen met de eerste trekken positief en veelbelovend zijn. Hij had de indruk dat discards verminderden door gebruik van het net. Het weer was toen niet zo goed. Toen het weer na een paar trekken opklaarde raakte het scheidingspaneel verstopt. Ze hebben toen verder gevist op de normale oude manier. Het grootste probleem van het huidige net vinden ze nu dat de ingang naar de viskuil te klein is. De N 350 heeft een bemanningslid aan boord die veel van netten afweet, het plan is dat hij het net wat zal aanpassen en dat ze dit gaan uitproberen. Wanneer is nog niet zeker. Het werk aan boord is zwaar, iets extra's erbij vergt veel energie.'

\section{- WR 18}

Viste er in week 24 en week 25 mee. In week 25 of 26 benaderd door Pieke Molenaar om zijn ervaringen te delen.

\begin{abstract}
Ervaring
Zit zeker potentie in. Groot belang is net als bij de garnalen zever dat die schoon blijft. Hebben nu 1 viszak van 8cm en 1 van $12 \mathrm{~cm}$ eraan. Zit evengoed kreeft bij. Met touwtje ff beter. Maar als $r$ geen meerdere collega's mee vissen gaat $t$ mij te veel kosten. De buren maken en meer uren en rapen de kreeft kleiner op. Dat hoort de bemanning ook. Is ook hun geld. Mijn voorstel is eerst maar de minimum maat omhoog en weekend verbod erop! Als t zo doorgaat en de vloot groeit zo door dan is t met 5 jaar bekeken.
\end{abstract}

Hebben geen grid. Zever schoon weinig verschil. Maar zodra ophoping 10/15 procent minder Zever smerig 20 procent minder. Schonere box is sneller verwerken. Maar dat lever je weer in met zever schoonkloppen. 
Vangst met standaard net WR 18, 21-6-2017.

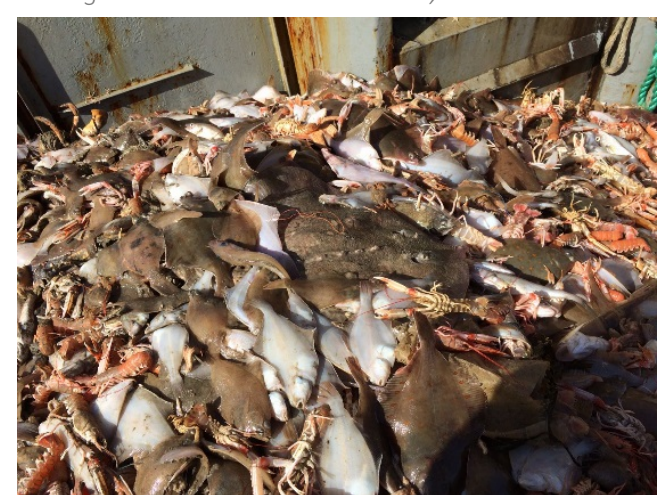

Vangst met SepNep WR 18, 21-6-2017.

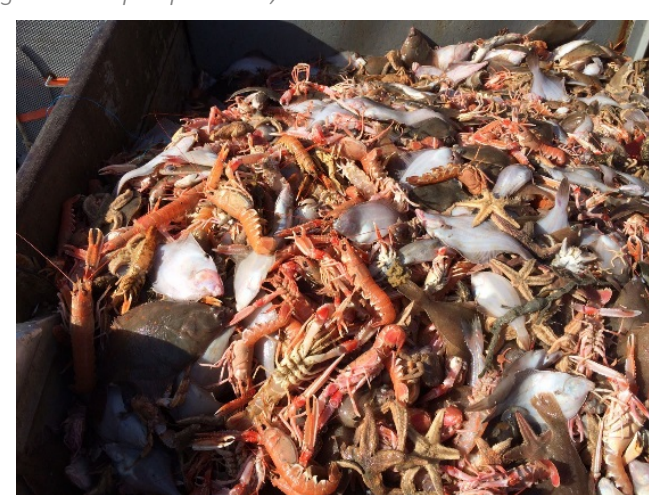

- ZK 2

Viste in week 25 met één SepNep, lag toen tijdje stil vanwege brandje, daarna omstreeks 26 en week 27 met twee. (was in ieder geval voornemens met twee te vissen).

Durk van Tuinen 6-7-2017: Ter info met betrekking tot de ZK 2 (SEPNEP). Wim vist nu met een van de vier netten met een SEPNEP. Nu 1 week gevist ermee, daarna kregen ze een brandje aan boord en lagen afgelopen week stil. Ondanks dat hij nog maar 3.5 etmaal heeft gevist met het SEPNEP durft hij te zeggen dat het een super uitvinding is. Nog wat kleine afstelwerkzaamheden moeten ze doen maar qua selectiviteit werkt het super. Waarschijnlijk op korte termijn een tweede SEPNEP erin zodat hij half om half vist. 


\section{Bijlage 7: Reisverslag Swedish grid}

\section{Netinnovatie 'Swedish Grid'}

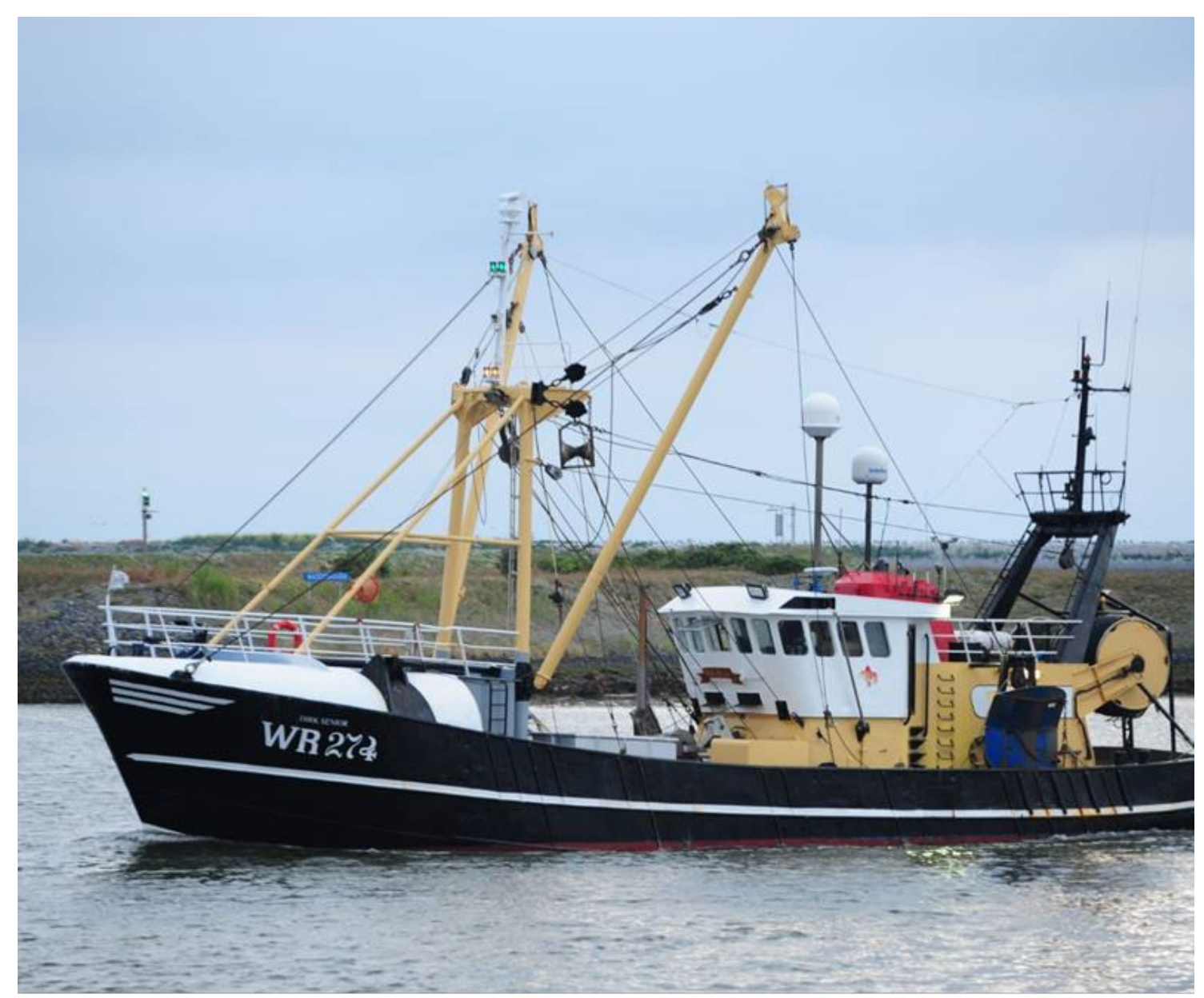

Verslag 1e onderzoek reis van 8 juli tot en met 13 juli 2018

Sander van Rijswijk Nettenmaker/ bedrijfsleider CIV Den Oever U.A. 


\section{Voorwoord}

Ten eerste willen we de toepassing van het 'Zweedse' grid in de Nederlandse visserij testen. Met als het doel selectiever vissen om ondermaatse platvis kwijt te raken maar marktwaardige langoustines, rondvis en platvis te behouden.

Het onderzoek is ook van belang om naast het SepNep een keuze aan de vissers te bieden tussen verschillende selectiviteitstoepassingen.

\section{Inhoudsopgave}

1. Wat vooraf ging

2. Het plaatsen van de grids in de netten

3. De testweek op zee

4. Eerste resultaten

5. Conclusies

6. Aanbevelingen voor een vervolg Samenvatting

Is het onderling scheiden van langoustines en ondermaatse platvis, marktwaardige vis mogelijk? Dit om een alternatief te bieden aan het Sepnep.

Naar aanleiding van eerdere tests met een groter 'Swedish grid', de reis naar Zweden wordt er een vervolg gemaakt door de bevindingen te implementeren in het net.

Er worden kleinere grids ontworpen en gemaakt.

Nadat de netten zijn klaargemaakt is er een week op zee getest aan boord van de WR 274 'Dirk Senior' van J.M. Zomerdijk met de hulp van schipper, bemanning en Sander van Rijswijk, bedrijfsleider en nettenontwerper van CIV Den Oever U.A. Per trek werd er naar de grid gekeken en de vangst bemonsterd. Aan het eind van de week is het project aan boord geëvalueerd en de toekomst besproken.

\section{Wat vooraf ging}

In 2017 is er gevist met een zgn. Swedish grid.
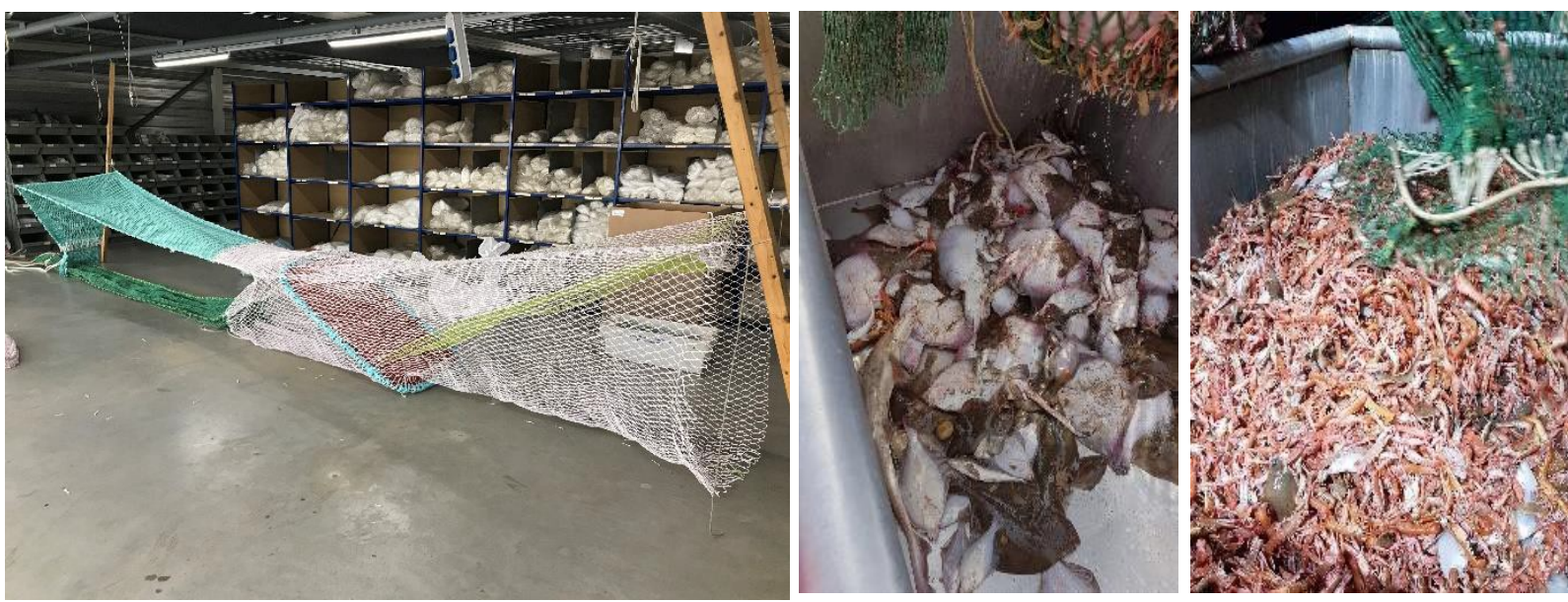

De resultaten waren toen bemoedigend. 
Echter naar verloop van tijd begon het vrij grote grid te vervormen welke de selectiviteit nadelig beïnvloedde. Tevens was de handling van het grid aan boord niet eenvoudig. Groot, onhandig, redelijk zwaar en moeilijk op de nettenrol te draaien.

Sander van Rijswijk heeft besloten om in samenwerking met de fabrikant een kleiner grid te ontwerpen

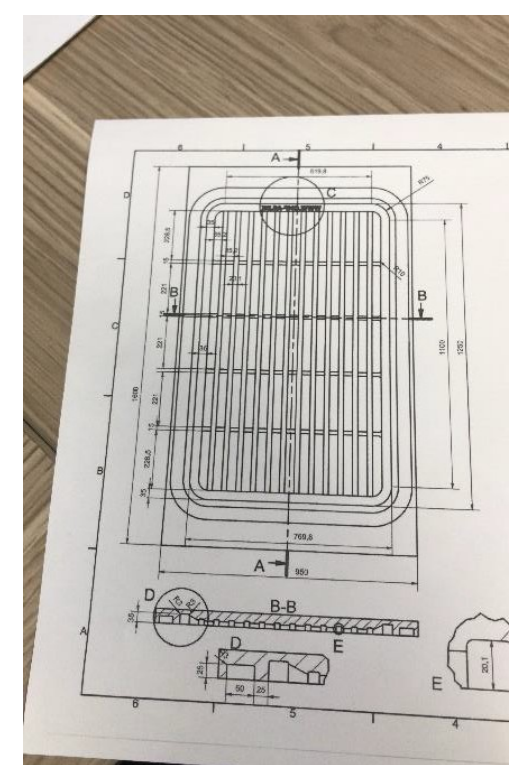

Niet alleen kleiner in formaat maar ook met versterkte horizontale ribben zodat het vervormen moeilijker wordt.

Omdat er 2 grids werden besteld is er gelijk gekozen voor 2 kleuren, rood en blauw. Dit naar aanleiding van de volgende tabel. Zichtbaarheid onder water.

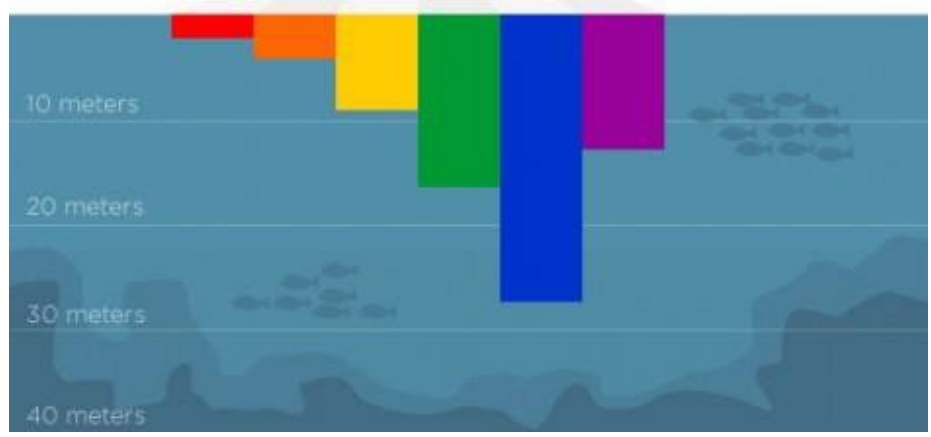

Misschien heeft de kleur invloed al zou dat op de bestekken waar op langoustines worden gevist, 40 tot 70 meter, waarschijnlijk geen invloed hebben. Verder zijn de grids identiek. 


\section{Het plaatsen van de grids in de netten}

Gekozen is om dat deel van het net waar het grid in wordt geplaatst in netwerk uit te voeren waar het normaal ook van is gemaakt.

A

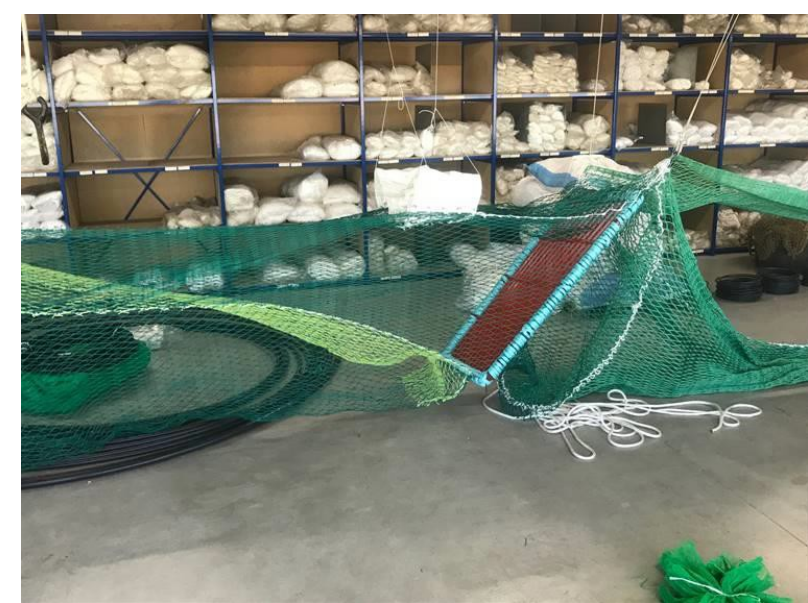

Grid $\mathbf{A}$ is het rode grid, afmeting $1250 \mathrm{~mm}$ hoog, $740 \mathrm{~mm}$ breed, gemaakt uit PU. Ruimte tussen de spijlen is $35 \mathrm{~mm}$. Hellingshoek 52 graden.

Aan de voorkant een tunnel van 50 mazen diep en een gele schuine lap om de vangst naar de onderkant van het grid te dwingen (dwingelap).

Aan de voorkant zie je een witte trawlkite zitten.

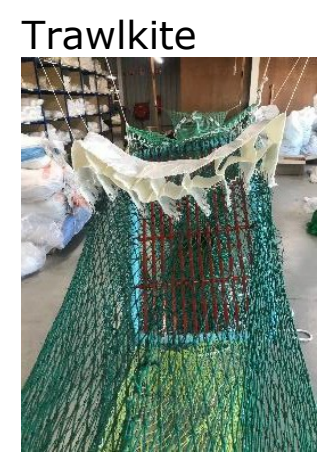

Dit in plaats van drijvers. We kijken naar het effect en zeker ook hoe makkelijk het op de nettenrol past. De vis gaat over de grid naar de bovenste zak. Deze is van 3 $\mathrm{mm}$ enkel netwerk met een maaswijdte van $87,9 \mathrm{~mm}$ ( omega gemeten, 10 mazen) De kreeft gaat door het grid en komt in de kreeftenzak. Deze is van $3 \mathrm{~mm}$ dubbel netwerk met een maaswijdte van $86,8 \mathrm{~mm}$ ( omega gemeten 10 mazen) 


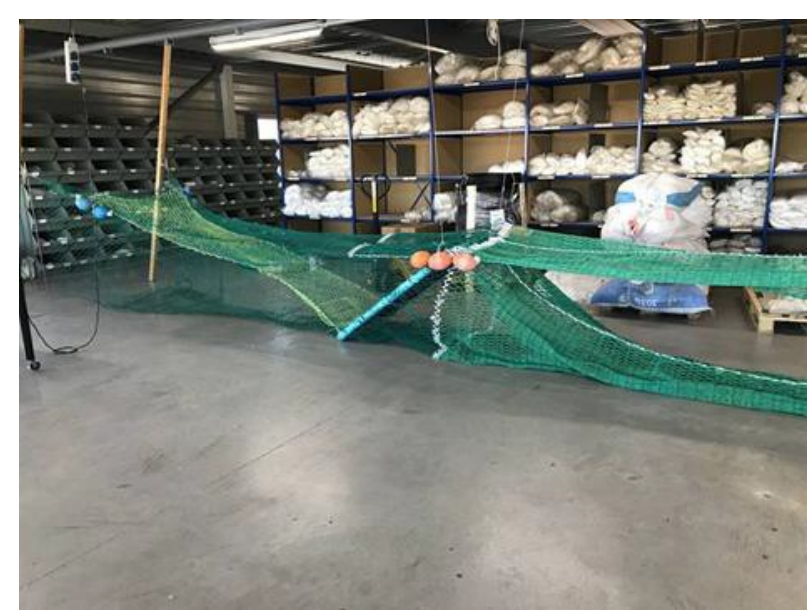

Grid B is het blauwe grid, afmeting $1250 \mathrm{~mm}$ hoog, $740 \mathrm{~mm}$ breed, gemaakt uit PU. Ruimte tussen de spijlen is $35 \mathrm{~mm}$. Hellingshoek 47 graden.

Aan de voorkant een tunnel van 50 mazen diep en een gele schuine lap om de vangst naar de onderkant van het grid te dwingen (dwingelap).

Bovenop zitten op strategische plaatsen drijvers gemonteerd. We kijken naar het effect en zeker ook hoe makkelijk het op de nettenrol past.

De vis gaat over de grid naar de bovenste zak. Deze is van $3 \mathrm{~mm}$ enkel netwerk met een maaswijdte van $88,6 \mathrm{~mm}$ ( omega gemeten, 10 mazen)

De kreeft gaat door het grid en komt in de kreeftenzak. Deze is van $3 \mathrm{~mm}$ dubbel netwerk met een maaswijdte van $86,9 \mathrm{~mm}$ ( omega gemeten 10 mazen)

De grids worden aan de 2 bestaande netten (nieuwe netten zijn helaas nog niet klaar) aan stuurboord gemaakt. Aan de 2 netten van bakboord zetten we 2 nieuwe keeftenzakken om alle 4 kreeftenzakken tegelijk te houden. Deze 2 zullen we nog meten met de Omega meter. We gaan er van uit dat het testen goed gaat en zullen dan gaandeweg de week 1 viszak wisselen voor 1 van een wijder type, namelijk $4 \mathrm{~mm}$ enkel netwerk, 108,7 mm tussen de knoop Omega gemeten. Verder zal ik een reservezak met tunnel meenemen mocht 1 van de grids stuk gaan. Ook garen, drijvers touw en ander materiaal om op zee mogelijk nog wat te wijzigen om de werking, indien nodig, nog beter te maken.

\section{De testweek op zee}

Zondagavond 8 september om 22.00 uur zijn we uitgevaren. De grid- panelen zijn aan de 2 bestaande netten (nieuwe netten zijn helaas nog niet klaar) aan stuurboord vastgezet. 

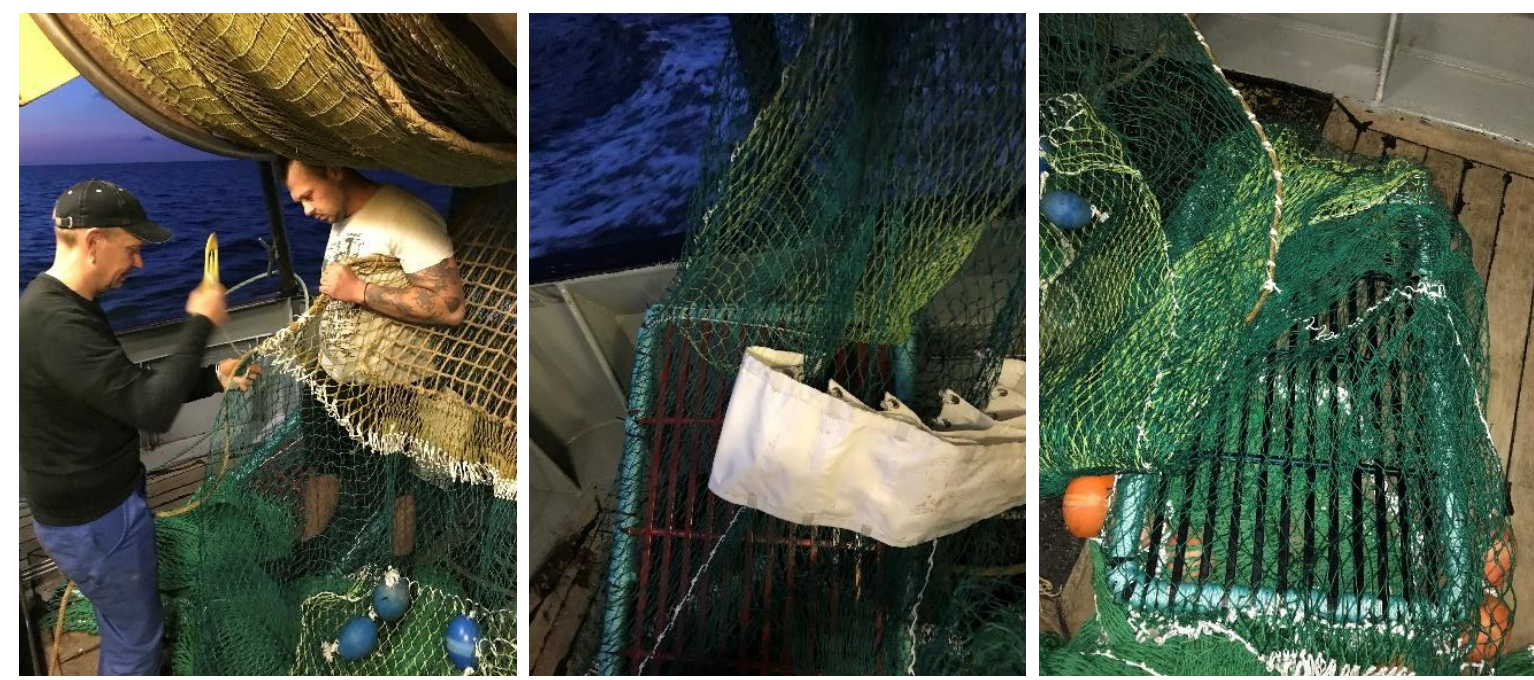

Er is koers gezet in noordwestelijke richting naar de langoustnebestekken in het Botneygat ( Botney Gut) 53.55 N om 3.05 E Daar gaat de hele week gevist worden. Wind is noordelijk kracht 3 tot 4 . Temperatuur rond de 17 graden.
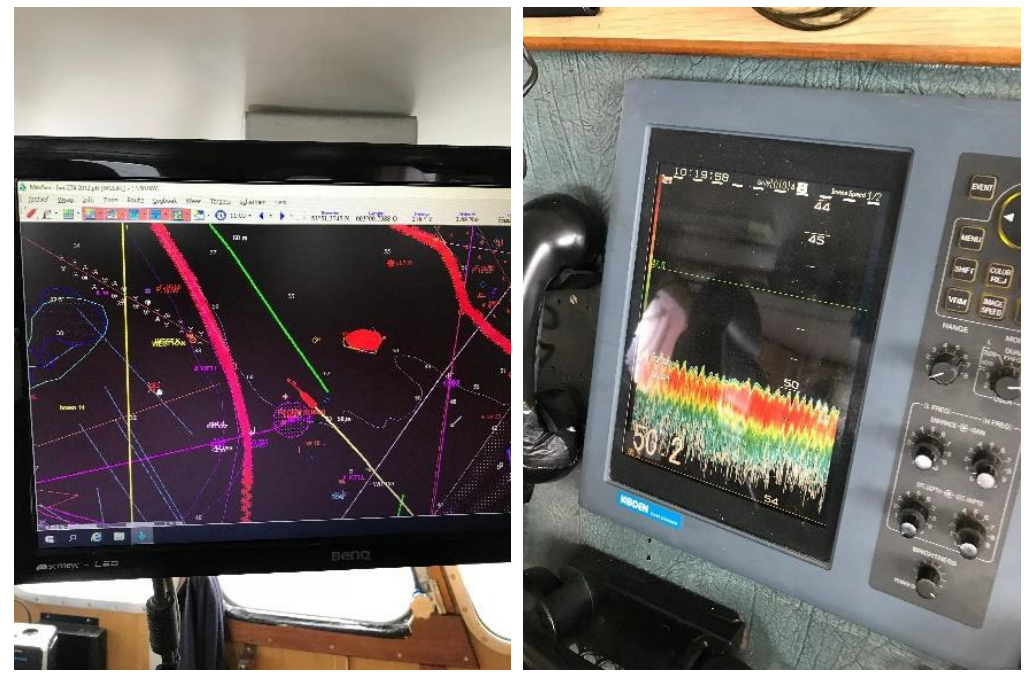

Maandagmorgen wordt er om 8.30 uur voor het eerst uitgezet en in NW- richting gevist. Trekduur zal de hele week rond de 5 uur zijn, vissnelheid rond de 3 knopen. $\mathrm{Na}$ elke trek worden de grids en de vangst bemonsterd tijdens en na het halen. Halen en vieren neemt in totaal zo'n 45 minuten in beslag. 

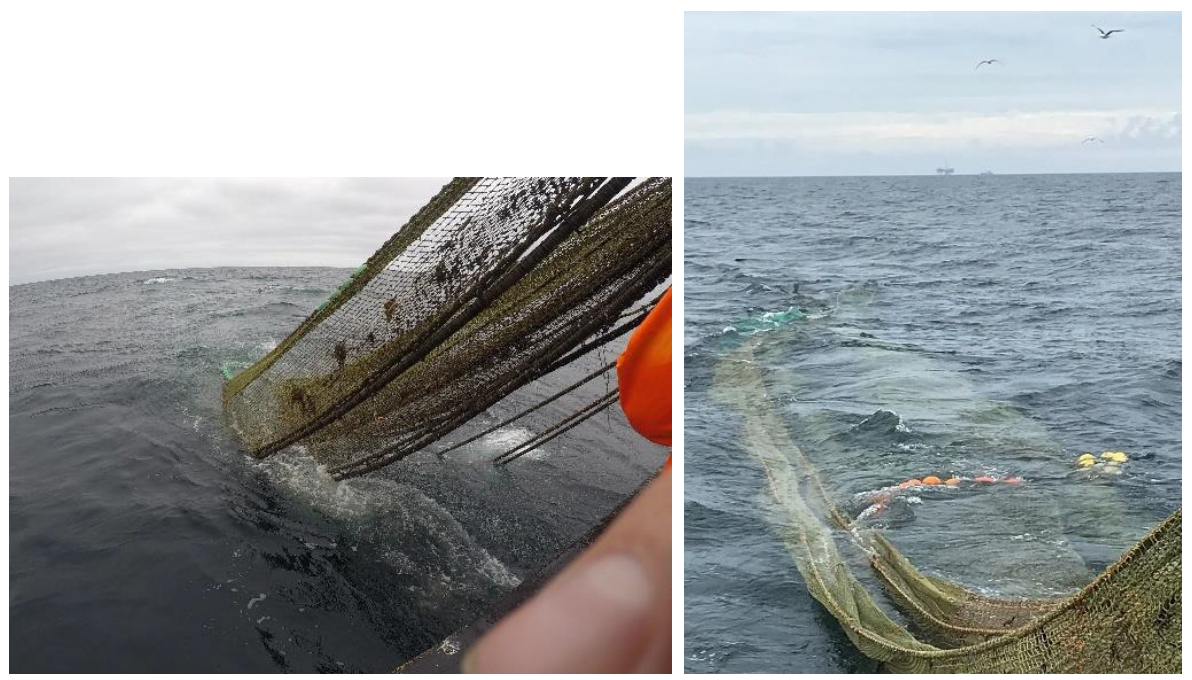

Dinsdag neemt de wind toe tot noord 7. De trekduur wordt langer vanwege de weersomstandigheden. De setting Grid A blijkt niet te functioneren, deze netaanpassing blijft duidelijk achter bij grid $B$, we besluiten om grid $A$ er af te halen. Het is niet eenvoudig een netaanpassing te maken op zee met dit weer.

Noord 6 tot 7
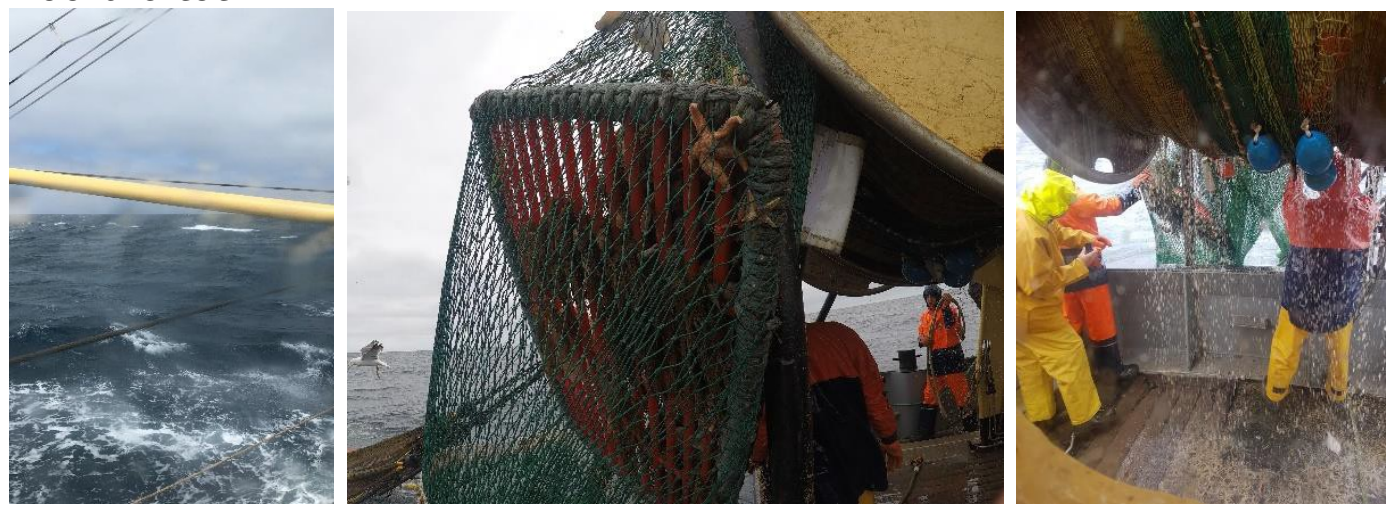

problemen met grid A Woensdag in de middag wordt het weer iets beter noord 5 . Telkens wordt er naar het grid en de vangst gekeken. Er wordt nu alleen de vangst bemonsterd aan de stuurboordnetten, daar er 1 net met een grid is, grid $B$, en 1 zonder grid (origineel/ stadaard). 


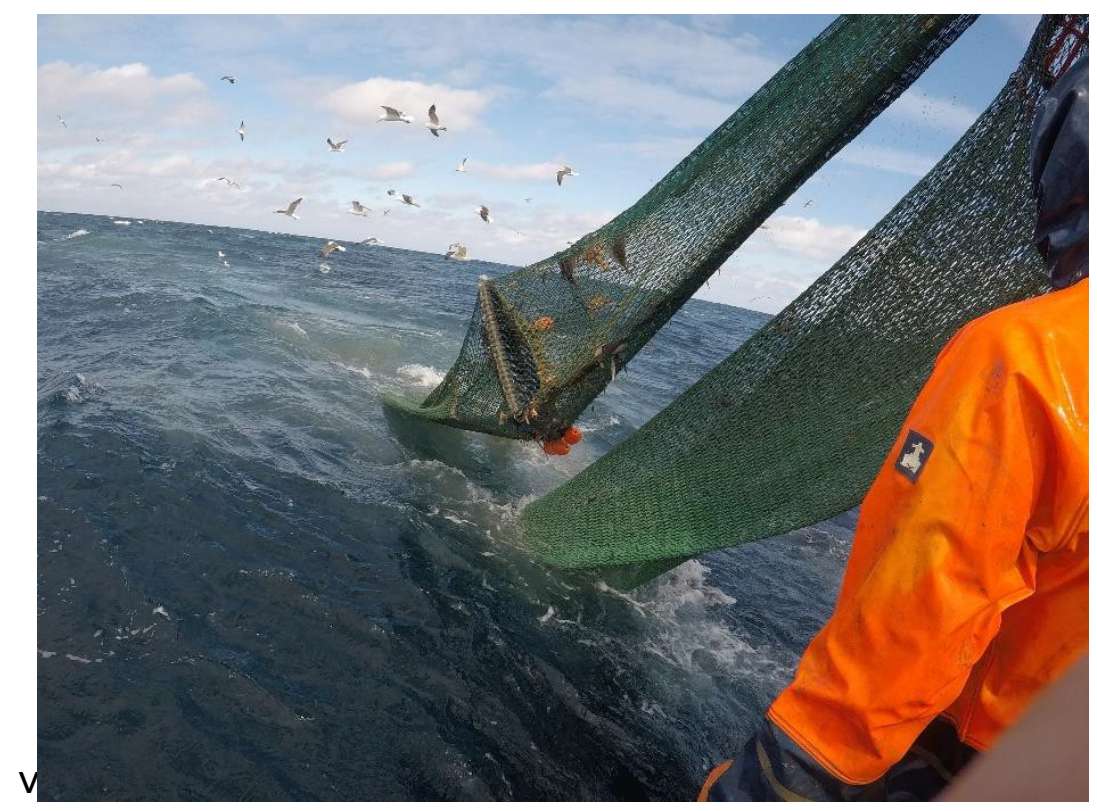

Woensdag is er ook nog een trek waarbij de vislijnen van de clump middengewicht) met die van het scheerbord in de knoop is geraakt. Deze trek is niet bemonsterd vanwege dat de boel in de knoop zat. Verder is alles gelukkig heel gebleven, alleen een uur of wat vistijd verloren. Verder proberen we nog een netaanpassing in de vorm van drijvertjes ( $E R$ BIJ/ ER AF).

drijvers er bij
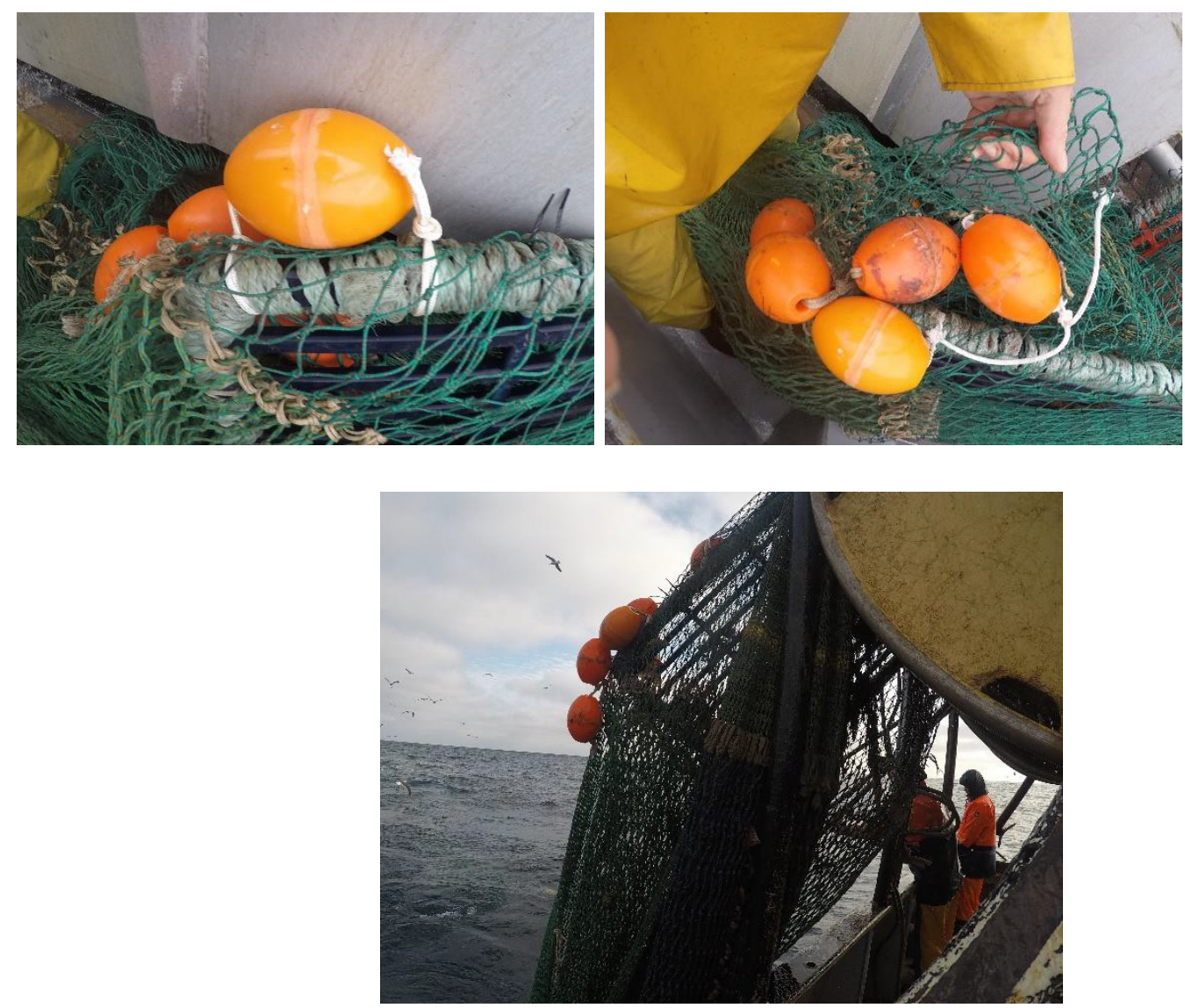

121 van 160 | Wageningen Marine Research rapport C051/19 
Donderdag is het weer mooi weer, noord 3 en wordt er 's avonds om 18.00 uur aan de zuidkant van het Botneygat gestopt met vissen. De netten worden schoongemaakt en er wordt koers gezet naar de haven om te lossen op de afslag van Den Oever.

Vrijdag 13 juli werden de netten nagekeken, het grid-paneel van het net afgehaald en het originele achternet met zak weer teruggeplaatst. Alles wordt van boord gehaald en de grid-panelen worden schoongemaakt en bij de CIV te drogen gehangen.

Grid-panelen drogen In de loop van de middag zijn we klaar.

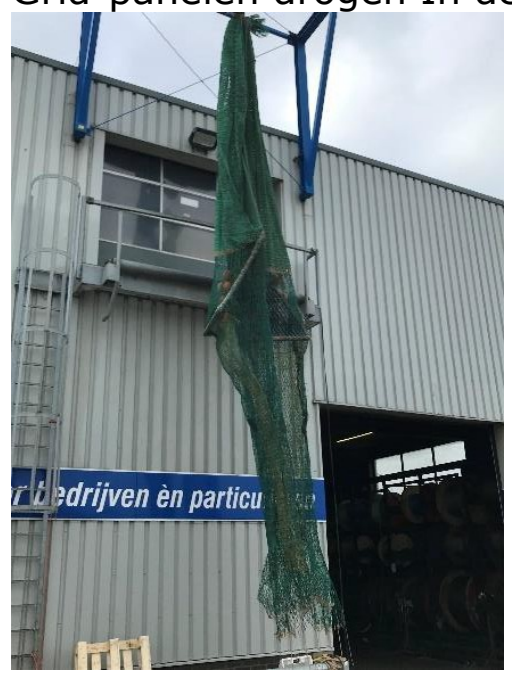

\section{4. eerste resultaten}

Gedurende de visweek is er gekeken naar de vangst. Eerste dagen is er gekeken naar de vangsten aan stuurboord en bakboord. De vangsten waren over de hele week zuinig, ook bij andere schepen die bij ons in de buurt viste ( N 350, WR 20, WR 189, WR 23). De totaalvolumes waren nagenoeg gelijk. Sommige trekken had bakboord wat minder.

Er blijkt een verlies van kreeft te ontstaan als het grid op zijn kant vist. Dit was vooral bij grid A het geval. Verlies was dan zo'n $25 \mathrm{~kg}$ ( totaal aan maatste en ondermaatse kreeft).

Nadat we grid A er hebben afgehaald, hebben we later alleen de 2 netten aan stuurboord vergeleken en het in de gaten gehouden of er geen verschil was tussen bakboord en stuurboord.

Er is een vergelijk gemaakt met de kreeftzak en viszak. Uitgesorteerd zijn de kreeft, ondermaatse schol, maatse schol, benthos (zeester, koetei, zeemuis wier, afval etc. ), maatse vis overige ( tarbot, griet, tong, schar, mul, kabeljauw, wijting, rode poon etc.) en discards overige ( ondermaatse vis als schar, wijting etc. )

Buksen, legen van de zakken 

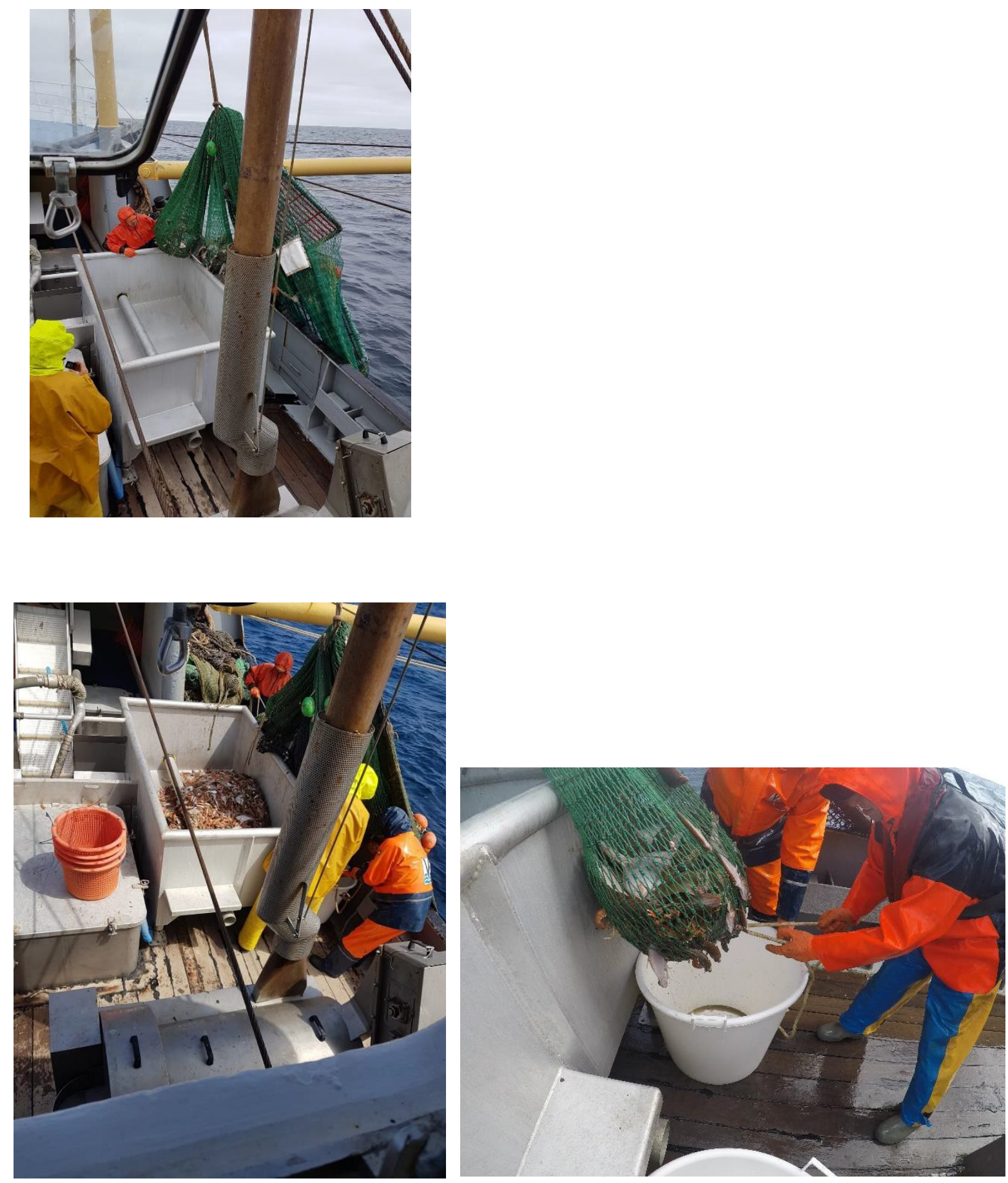

Kreeftenzak Viszak 


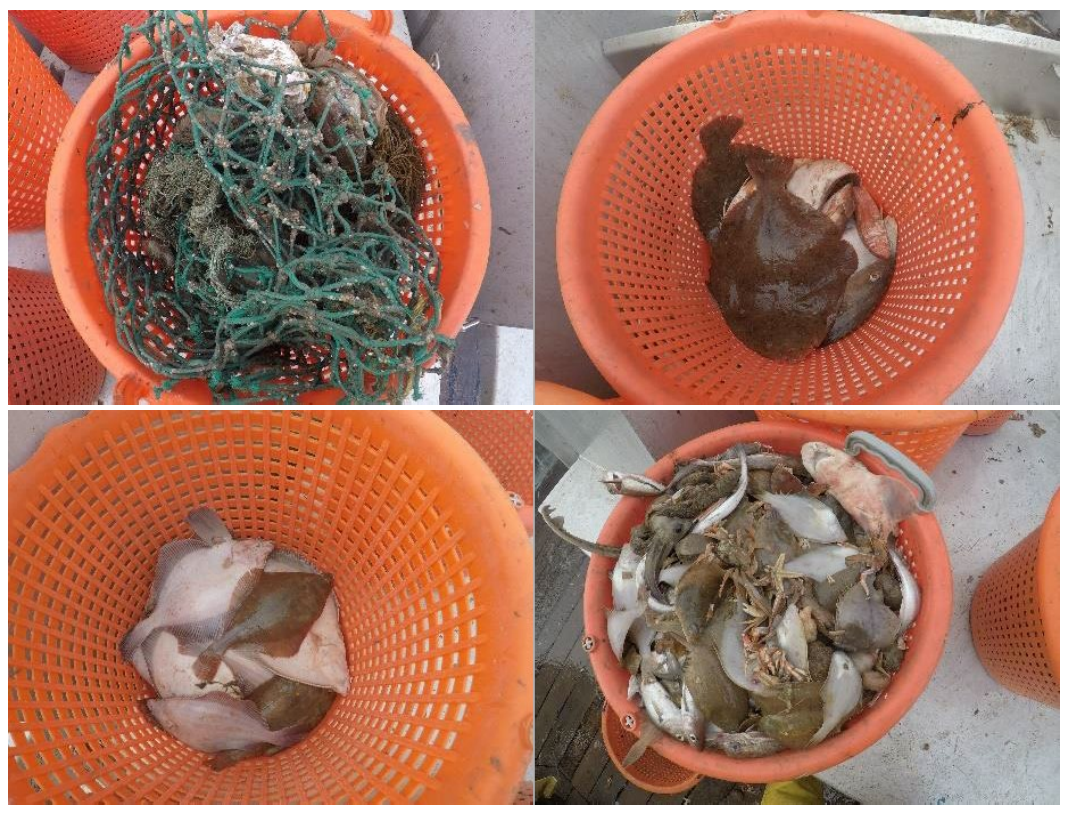

Er is weinig kreeft die in de viszak terechtkomt zo'n 3 tot 6\%, zijn wel meest marktwaardige kreeften.

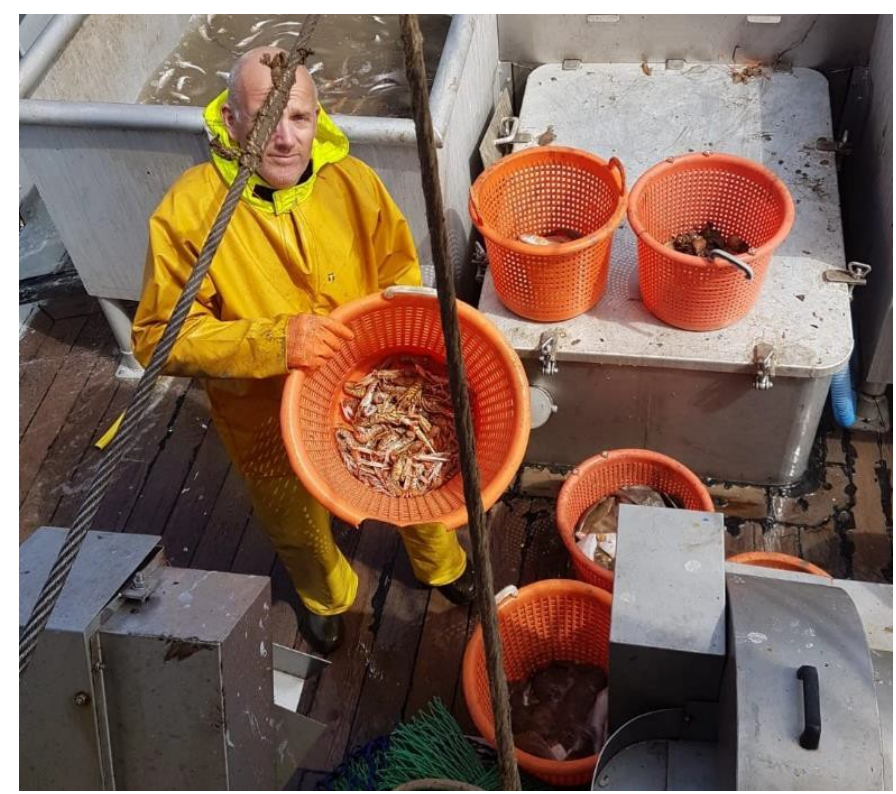




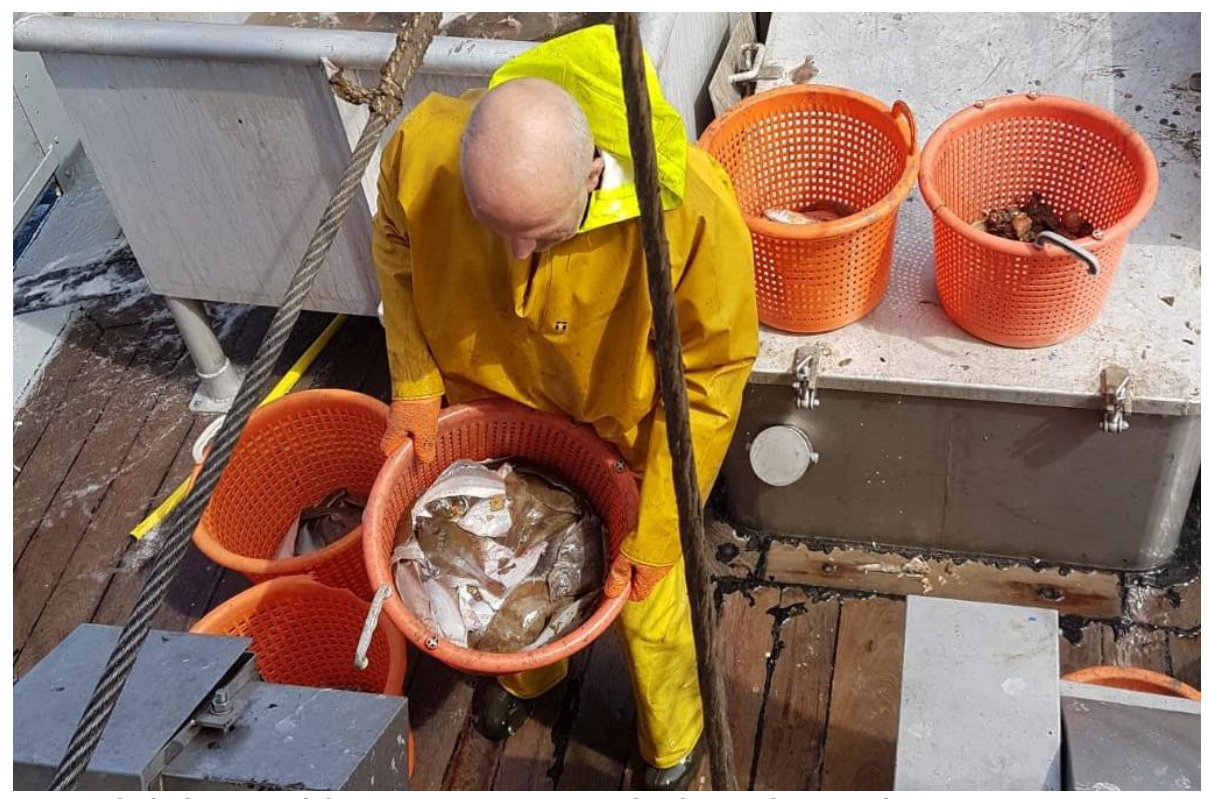

Er zit redelijk wat kleine wijting in de kreeftenzak.

Soms zit er ook wat maatse schol in de de kreeftenzak, geen kilo's maar stukstallen. Ook tong komen we tegen in de kreeftezak maar ook in de viszak.

\section{5. conclusies}

Op vrijdag hebben we aan boord de visweek en de resultaten besproken. De eerste conclusies zijn;

- Het kreeftenverlies is acceptabel

- De sorterende werking is naar tevredenheid en kan nog wat beter.

- De trawlkite werkt niet, waarschijnlijk is de waterstroom op het achtereind tekort of anders waardoor de kite onvoldoende water krijgt om een liftend effect te geven.

De kite was vies van de prut, wat niet hoort.

- Doordat de kite niet werkte ging grid A makkelijk op zijn kant liggen, waardoor de werking van grid verloren ging. Vis hoopte zich op aan de onderkant van de dwingelap, kreeft ontsnapt door de onderzij.

- We krijgen het idee dat de grids soms instabiel zijn. Dat wil zeggen dat ze tijdens het vissen op hun zij vallen. Volgens ons gebeurdt dat tijdens de trek, bij het rondgaan ( keren op het visbestek), daarna gaan ze niet altijd uit zichzelf meer omhoog (rechtop).

Wel gaan de grids goed te water (rechtop).

- De grids gaan redelijk goed op de nettenrol, dus de positie in het net is goed

- De grids zijn te handelen bij het overboord gooien tijdens vieren, halen en boxen ( vangst uit de zak legen).

- Netwerk rond de grids, tunnel en dwingelap is te dun.

- Drijvers aan de voorkant van de dwingelap werken averechts.

- Kleur van het grid maakt waarschijnlijk niet uit 


\section{Aanbevelingen voor een vervolg}

Het was een mooie week en het blijkt toch dat het het beste is om dingen te testen op zee.

De omstandigheden daar hebben zeker invloed welke je in de nettenmakerij of op de tekentafel niet kan inschatten.

Onderstaand een aantal aanbevelingen voor een vervolg reis;

- Netwerk tunnel vervangen door dikker netwerk, meer mazen opzet.

- Dwingelap meer mazen opzet en de voorkeur is nauwer netwerk gebruiken.

- Viszak vastzetten op de kreeftenzak of er een tweelingkuil van maken, voorkomt draaien en in de knoop raken van de zakken.

- Hoekstandmeter op grid zetten zodat men kan monitoren wat de stand van het grid is gedurende de trek. Dat geeft ook een uitstekend beeld wanneer er veranderingen worden toegepast. Pieke heeft een link gestuurd van een bedrijf die zoiets blijkbaar heeft.

- Meer drift

- Sleeplap of pluis of Yakleer aan de onderkant van het grid plaatsen, voorkomt slijtage.

- Gebruikmaken van borden sensor systeem ( Notus/ Scanmar) om de borden- netopening te monitoren en dan vooral bij het rondgaan.

- Een wijdere viszak toepassen als men er van overtuigd is dat het grid werkt.

- Plaats van het grid in het net handhaven

- Grootte van het grid eerst handhaven.

- 2 grids tegelijk testen. Starten met exact dezelfde uitvoering zodat men 1 kan aanpassen en dan het effect vergelijken met de andere die niet is gewijzigd.

- Zoektafel aan boord, en eventueel iets maken in de bukshokken om de vangst gescheiden op te vangen en daarna te sorteren.

- En misschien wel het belangrijkste, zorgen voor een goede vergoeding, een basisbesomming, nu is men de hele tijd in de weer met het doen van onderzoek terwijl daar nauwelijks een onkostenvergoeding tegenover staat.

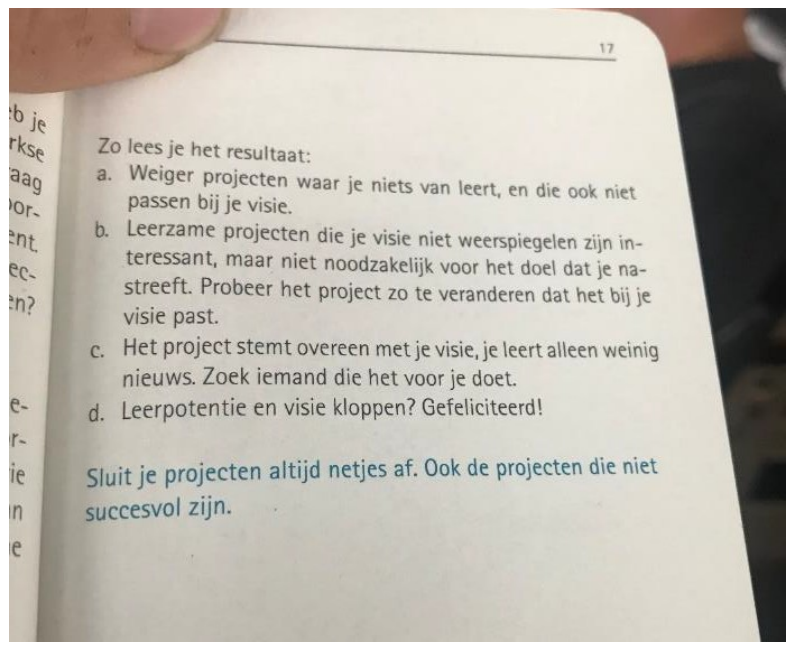

Met dank aan John-Mark, Rene en Matusz De bemanning van de WR 274 'Dirk Senior' 


\section{Resultaten swedish grid WR274}

In deze bijlage zijn de hellingshoekmetingen en diepte per trek weergegeven. Bij trek 1, 5 en 6 stond het grid in de gewenste hellingshoek, in de overige trekken heeft het grid een deel van de trek op zijn kant gevist. Daaronder is de vangstsamenstelling per trek weergegeven.

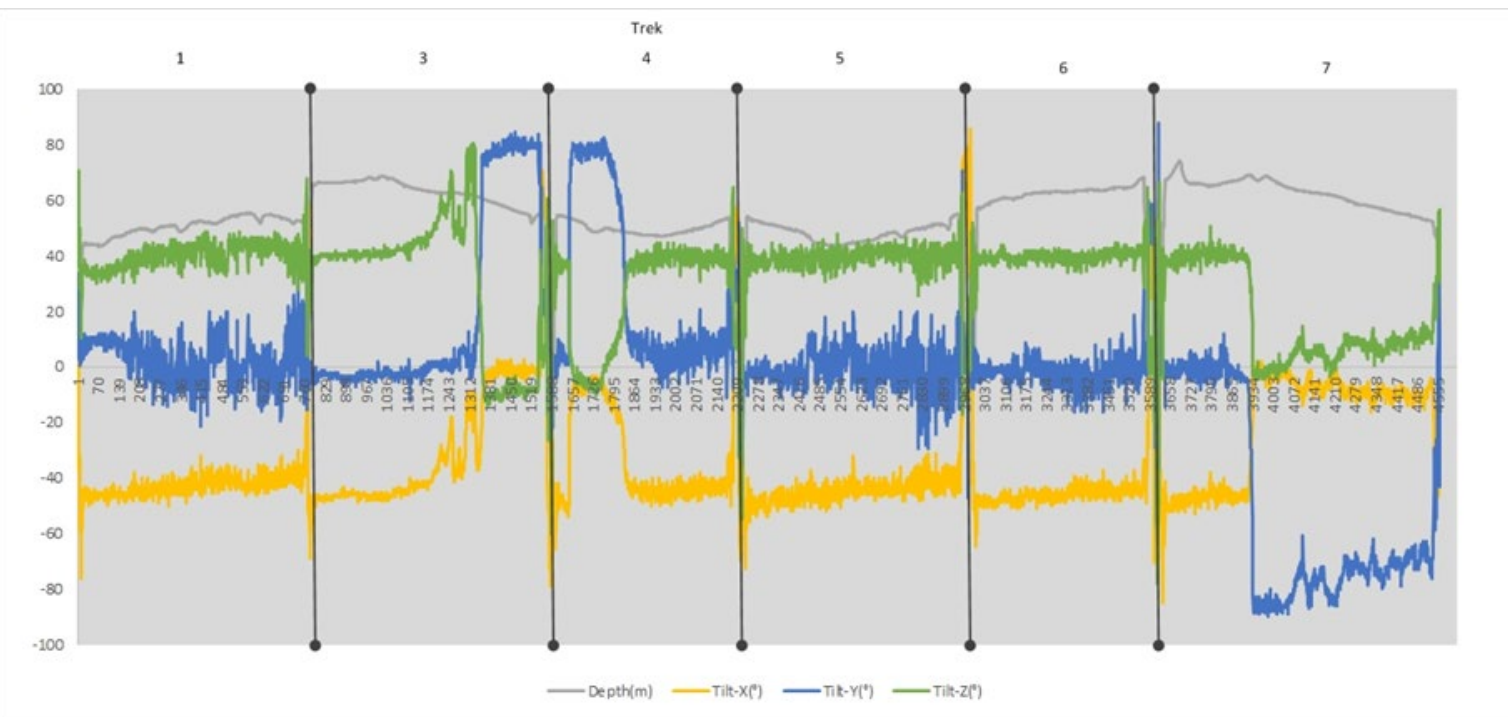

Gemiddelde vangstsamenstelling

WR274_2019_w50 Trek_1

discards

landings
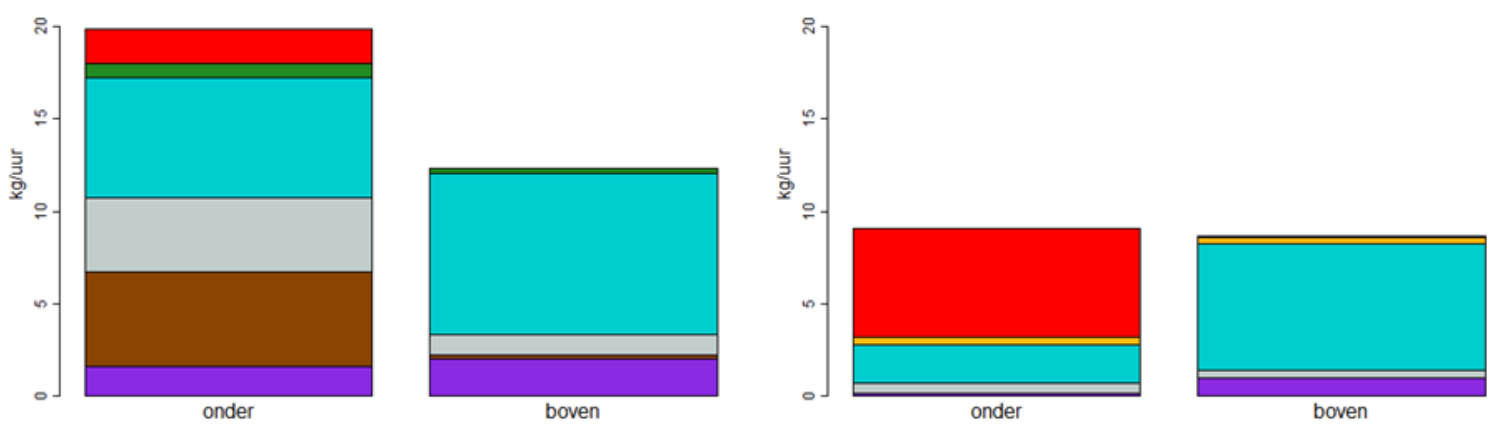

averige
benthos

믈 Merlangius merlangus ㅁ Limanda limanda
Pleuronectes platessa

- Nephrops norvegicus 


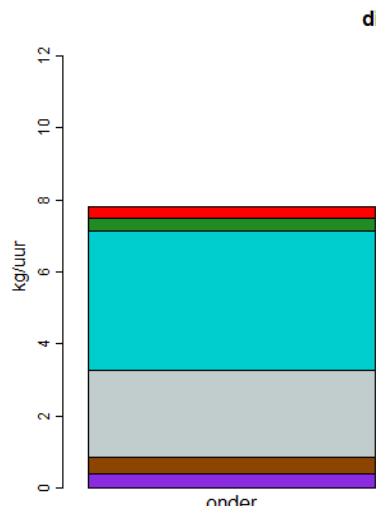

onder discards

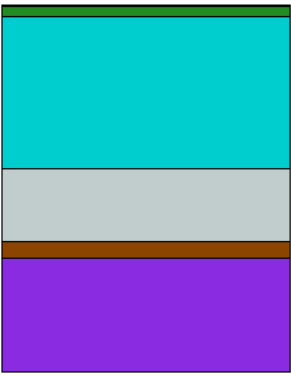

boven

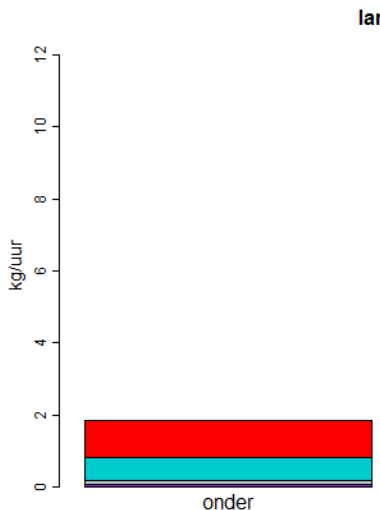

- Nephrops norvegicus

믈 overige

․ Merlangius merlangus Limanda limanda

Gemiddelde vangstsamenstelling

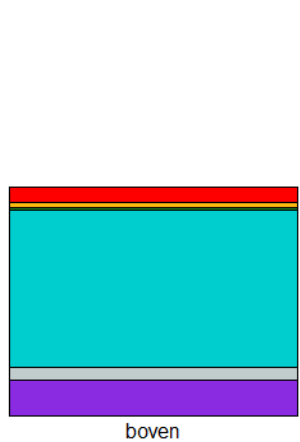

boven

ndings

WR274_2019_w50 Trek_3

discards

landings
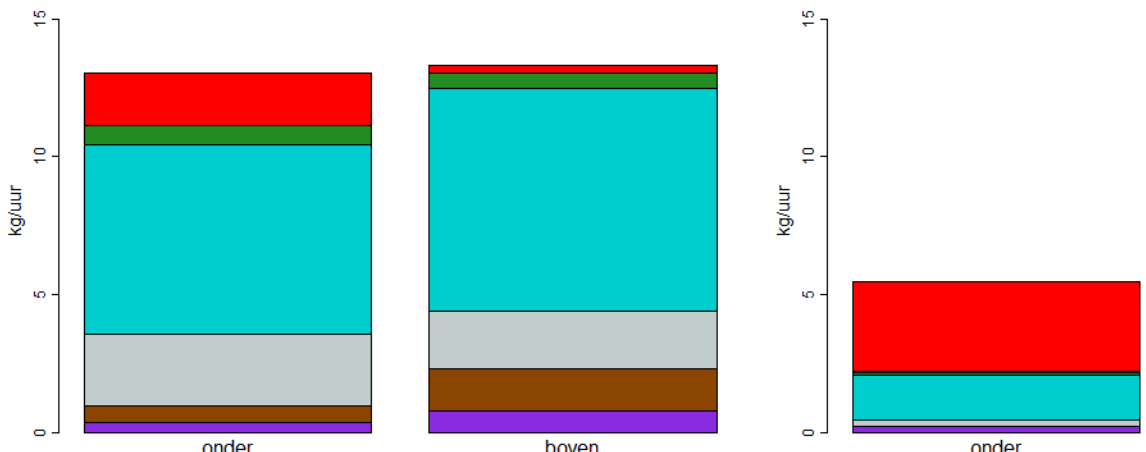

ㅁ Merlangius merlangus
$\square$ Pleuronectes platessa Limanda limanda

- Nephrops norvegicus

믈

Gemiddelde vangstsamenstelling

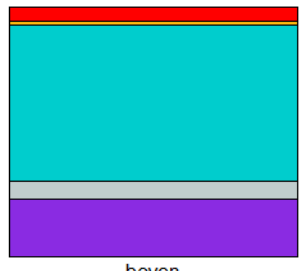

boven

WR274_2019_w50 Trek_4

landings
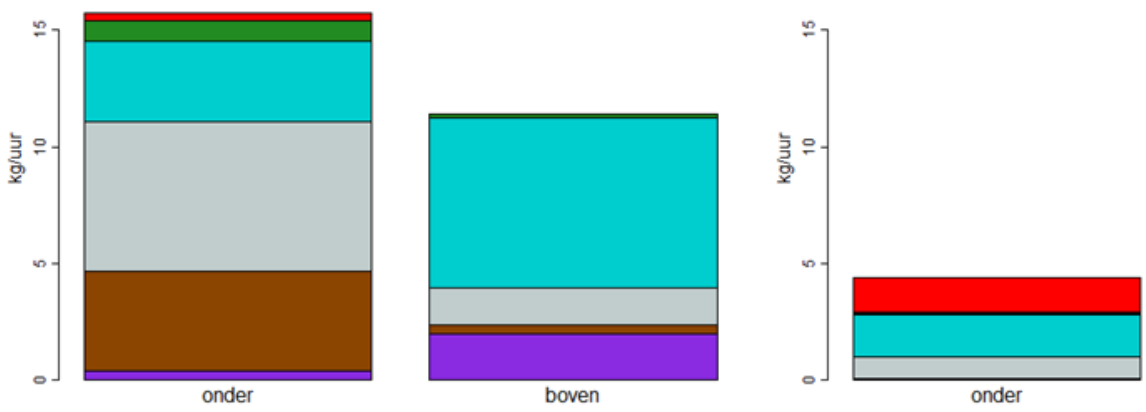

onder

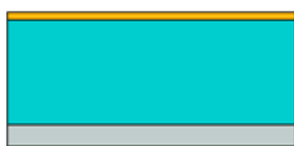

boven

- Nephrops norvegicus 
discards

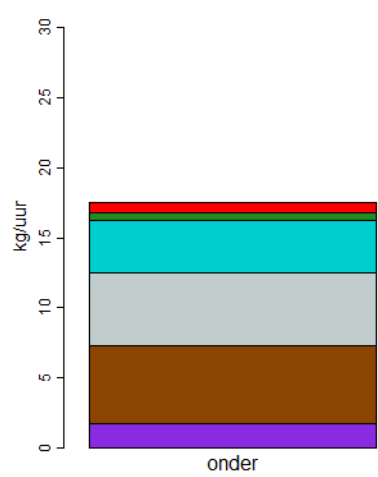

onder

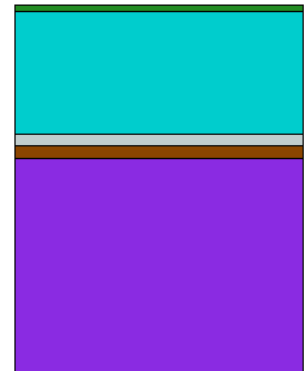

boven

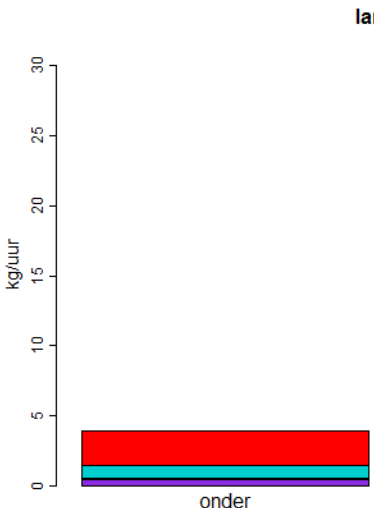

- Nephrops norvegicus

averige
benthos

ㅁ Merlangius merlangus $\square$ Limanda limanda

Gemiddelde vangstsamenstelling

discards
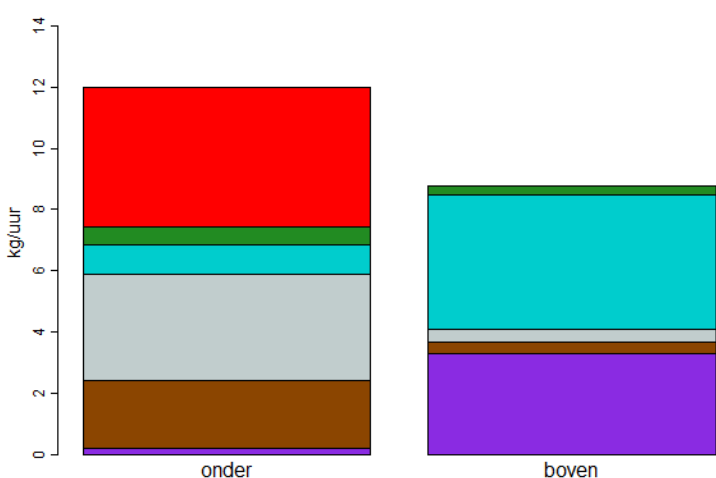

boven

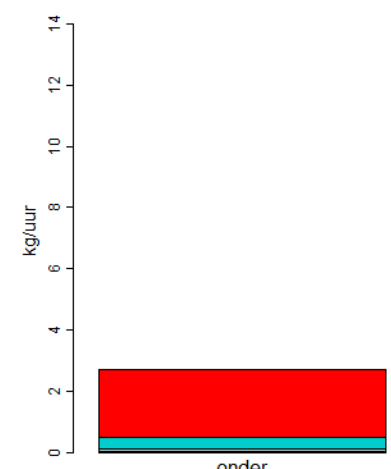

landings

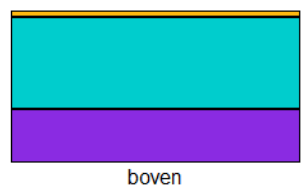

boven

WR274_2019_w50 Trek_6

landings

overige
benthos

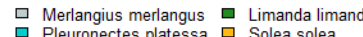

- Nephrops norvegicus

Gemiddelde vangstsamenstelling

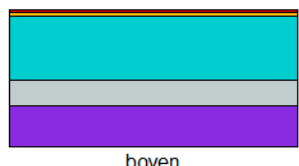

boven

landings
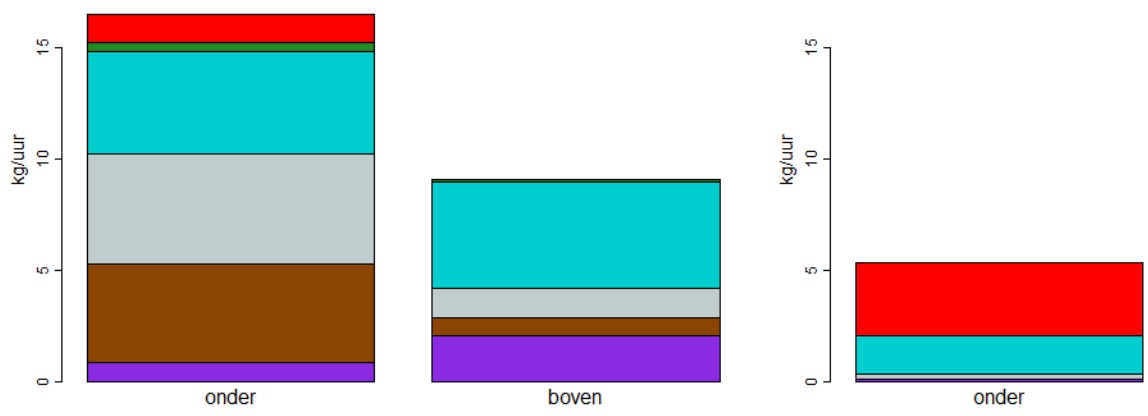

onder

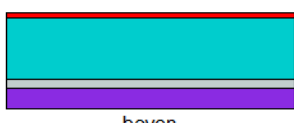

boven

- Nephrops norvegicus 



\title{
Bijlage 8: Reisverslag studiereis Noorse kreeft en netinnovatie
}

\author{
Organisatie: Nederlandse Vissersbond \\ Onderwerp: Verslag studiereis Netinnovatie Zweden \\ Datum: $\quad 20$ april 2018

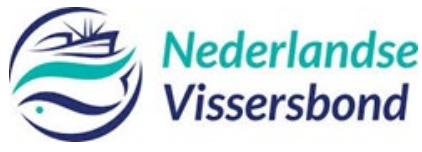 \\ Auteur: $\quad$ Brita van den Dries-Trapman \\ Namens: $\quad$ Projectgroep 'Netinnovatie Kottervisserij deel 2'

\section{Inleiding} \\ Van zondagavond 15 april tot en met woensdagmiddag 18 april reisde een groep van in totaal \\ veertien personen, bestaande uit visserijvertegenwoordigers, vissers en nettenmakers, af naar \\ Gotenburg (Zweden). Doel van de reis was om de behaalde resultaten, met name op het gebied \\ van de visserij op Noorse kreeft, en de plannen binnen het project Netinnovatie Kottervisserij deel \\ 2 met de Zweedse visserijsector en met onderzoekers te delen en om te leren van het Zweedse \\ visserijonderzoek. Aanleiding van het onderzoek was een uitnodiging van de Zweedse PO-voorman \\ Peter Olsson nadat de Nederlandse Vissersbond het succesvolle SepNep (selectief net voor de \\ visserij op Noorse kreeft) had gepresenteerd tijdens een bijeenkomst van de North Sea Advisory \\ Council in Parijs in februari 2017.
}

\section{Maandagochtend: kennismaking en introductie}

De organisatie die ons ontvangt, de Zweedse SFPO, is de grootste PO voor de demersale visserij in Zweden met leden aan de westkust die in het Skaggerak, Kattegat, de Noorse wateren en de Noordzee vissen en leden aan de Oostkust die in de Baltische zee vissen. De pelagische vissers hebben hun eigen PO. Voorman Peter Olsson heeft zelf jaren gevist en hij bezit daardoor veel kennis van de visserijpraktijk.

\section{Overeenkomsten en verschillen}

Maandagochtend voeren we een kennismakingsgesprek met PO-voorman Peter Olsson. De Zweedse visserij kampt net als de Nederlandse met verscheidene bedreigingen zoals de bouw van windmolenparken op zee, gebieden die gesloten worden ten behoeve van natuurdoelstellingen en een sterke NGO-gemeenschap die, in de woorden van Olsson: 'niet rust voordat de bodemvisserij is verdwenen'. Op veel vlakken verschilt de Zweedse demersale visserij ook van de Nederlandse. Waar Nederlanders veel voor de export vissen, vissen de Zweedse demersale vissers vooral voor de nationale markt en zij landen dagelijks een zeer vers product aan. Dit is goed mogelijk omdat de visgronden niet ver buiten de havens liggen. Waar de Zweden na 1,5 tot 2 uur stomen al op de visgronden met langoustines zijn, moeten Nederlandse vissers 8-10 uur stomen om op langoustines te kunnen vissen. De Zweden vissen zowel met korven als met sleepnetten op Noorse kreeft, Nederlanders alleen met sleepnetten. De door Zweden gevangen pelagische vis wordt wel grotendeels geëxporteerd.

Olsson licht toe dat ze in Zweden momenteel twee grote projecten hebben die uit Europees geld worden gesteund. Het ene project heeft als doel om de bodemimpact in de bordenvisserij te verminderen door onderzoek te doen naar borden die minder bodemcontact maken. Het andere project vindt plaats in de Baltische zee. Kustvissers hebben daar veel last van vraat door zeehonden waardoor hun visserij niet meer rendabel is. Er wordt gezocht naar aanpassingen en nieuwe visserijmethoden die de vangst beschermen tegen zeehonden. 


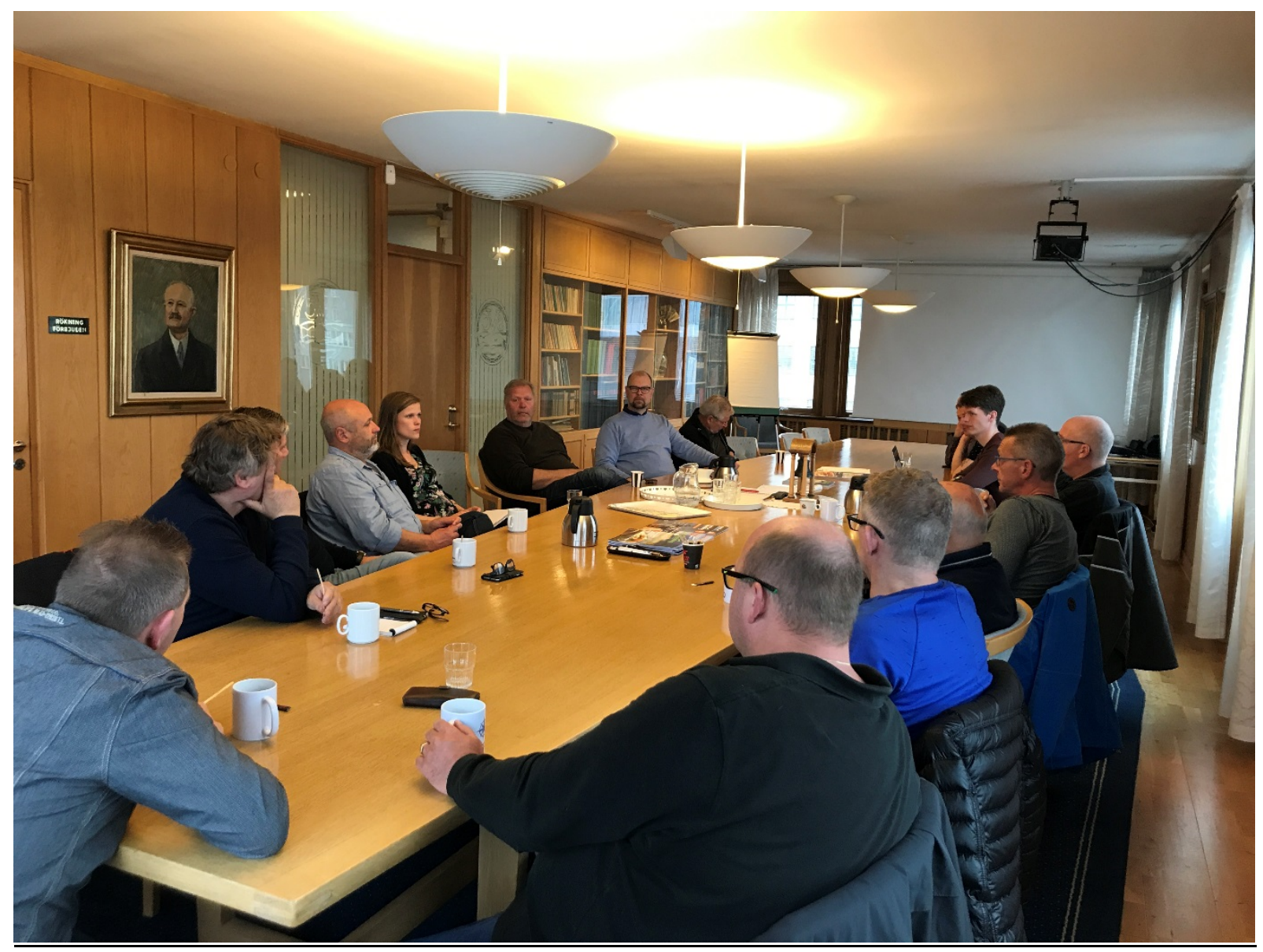

Foto 1 Kennismaking en introductie op het kantoor van SFPO.

\section{Windmolenparken}

Wat betreft de windmolenparken hebben de Zweden goede ervaringen met Deense exploitanten, die doen hun best om ruimte te behouden voor de visserij en om gezamenlijke afspraken te maken. Zweedse exploitanten denken niet aan de visserijsector.

De toegenomen druk op visgronden heeft de Zweedse PO-vertegenwoordigers op het idee gebracht om het begrip Protected Fishing Areas te gaan gebruiken en te promoten. Dit verwijst naar gebieden die gereserveerd zijn voor visserij, zodat hier geen andere activiteiten ontplooid kunnen worden.

\section{$\underline{M S C}$}

De Noorse kreeftvisserij in Zweden is MSC-gecertificeerd. Daarnaast werken de Zweden o.a. met de Nederlandse sector samen om meer demersale soorten MSC-gecertificeerd te krijgen of te houden. De Zweden merken niet dat ze voor MSC-gecertificeerde producten een betere prijs ontvangen, ze hebben het label echter nodig omdat de markt of publieke aanbestedingen dit vereisen. De Nederlanders herkennen dit.

\section{Garnalen en quota}

In Zweden zijn de Noorse garnalen (pandalus borealis) een ware delicatesse die veel gegeten wordt in combinatie met witte wijn. De Zweedse visserijsector alleen kan niet in deze vraag voorzien. Sinds kort zijn voor demersale soorten, waaronder Noorse garnaal, individueel verhandelbare quota (ITQ) ingevoerd. De Zweden hebben bij het ontwerpen van hun quotumsysteem goed gekeken naar andere landen waar ze ITQ-systemen hebben. De Zweden wilden voorkomen dat de kustvisserij door het opkopen van quota zou verdwijnen zoals dat in Denemarken is gebeurd, daarom worden in het Zweedse systeem speciaal quota gereserveerd 
voor de kleinschalige vloot. De Zweedse sector heeft voor het ITQ-systeem gelobbyd en heeft het zelf ontwikkeld, het geeft hen meer flexibiliteit, vooral om aan de aanlandplichtregelgeving te voldoen is dit van groot belang.

\section{Aanlandplicht}

Soorten die een probleem vormen voor de Zweden onder de aanlandplicht zijn kabeljauw in de Noordzee, wijting en kever. Het Swedish grid helpt om in de visserij op garnalen en Noorse kreeft ondermaatse rondvis of rondvis waarvoor beperkt quotum is kwijt te raken. Daarnaast werken de Zweden samen met de Denen om het quotum voor wijting in het Skaggerak op te heffen met als voorwaarde dat er geen gerichte wijtingvisserij mag ontstaan.

\section{$\underline{\text { Vergrijzing }}$}

De Zweedse visserij kampt net als de Nederlandse met vergrijzing. Jonge Zweden die visser willen worden moeten in Denemarken naar school omdat in Zweden alle visserijscholen gesloten zijn. En hoewel er ruim langoustinequotum voorhanden is, vissen de Zweden maar 38\% op omdat het zo moeilijk is om een licentie te krijgen om te mogen vissen.

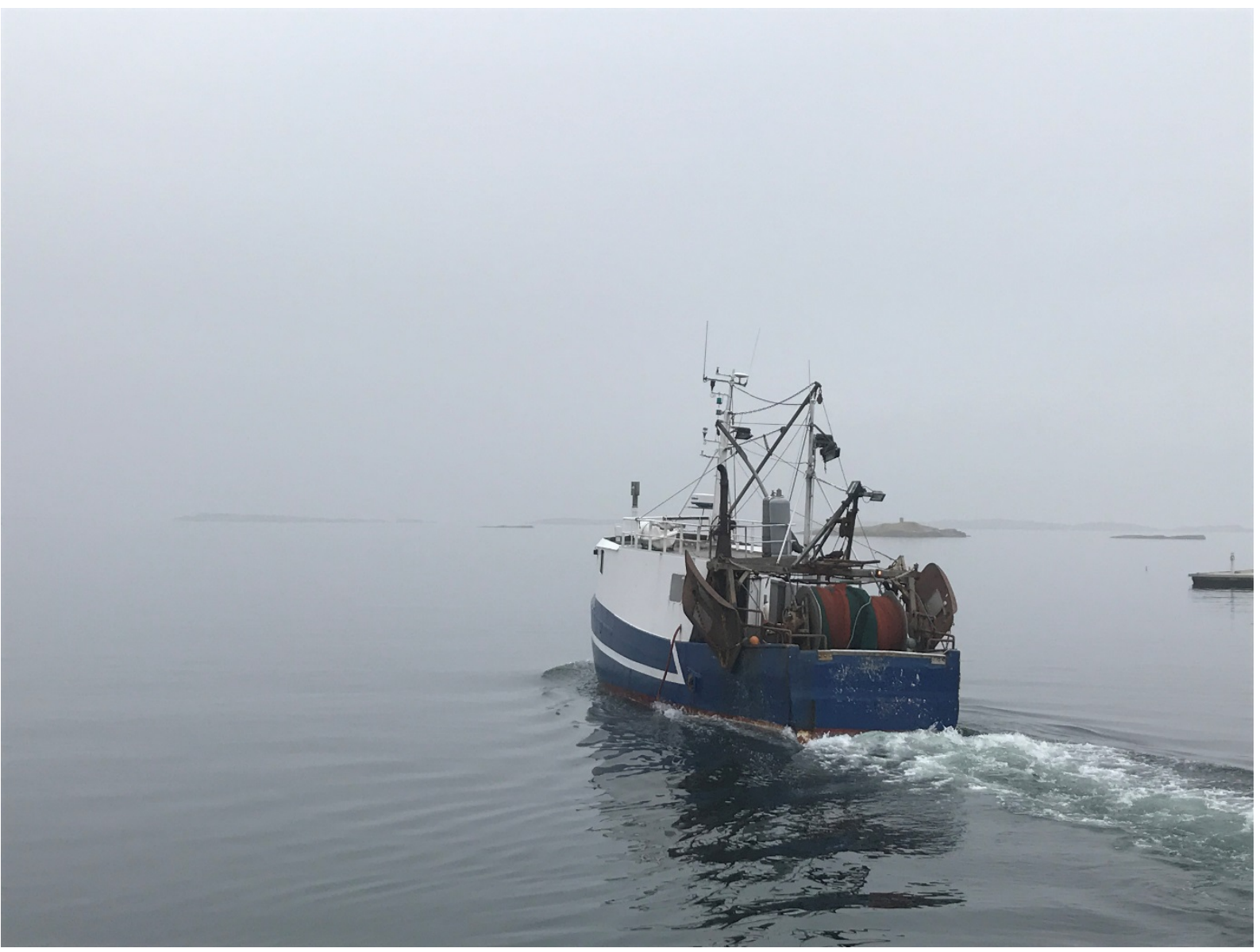

Foto 2 Een Zweeds schip dat met korven op langoustines vist vanuit de haven in Smögen.

\section{Maandag middag: bezoek nettenmakersbedrijf}

's Middags bezoeken we een innovatief nettenmakersbedrijf in Smögen, een vissers- en toeristenplaatsje op 1:45 uur rijden vanaf Gotenburg. Om rendabel te blijven heeft het bedrijf zich toegelegd op de ontwikkeling van selectieve visserijtechnieken en het schoonhouden van het mariene milieu. De ontwikkelaar van het Swedish grid, die tevens oud-visserman is, roept op tot samenwerking tussen verschillende visserijgemeenschappen om gezamenlijk voorstellen te doen voor verduurzaming, zodat maatregelen werkbaar zijn en niet top-down worden opgelegd. 


\section{Het Swedish grid}

In de nettenschuur hangen een garnalennet en een langoustinenet, beide met een Swedish grid erin. Een Swedish grid is een grid met spijlen waar de garnalen of langoustines doorheen passen maar de vis niet. De garnalen of langoustines komen in een kuil terecht zonder vis. De vis kan door openingen bovenin het grid. Achter de openingen kan zich een tweede kuil bevinden maar het kan ook open zijn zodat alle vis kan ontsnappen. Of een visser een viskuil gebruikt en welke maaswijdte hij hanteert is afhankelijk van zijn quotum. Heeft hij veel visquotum dan is de kans groot dat hij een kuil bevestigt. Heeft hij wel visquotum maar weinig dan kan het lonen om een kuil met grote mazen achter de gridopeningen te bevestigen zodat alleen de grote, dure vis gevangen wordt en er dus zo veel mogelijk verdiend wordt met het opvissen van het quotum.

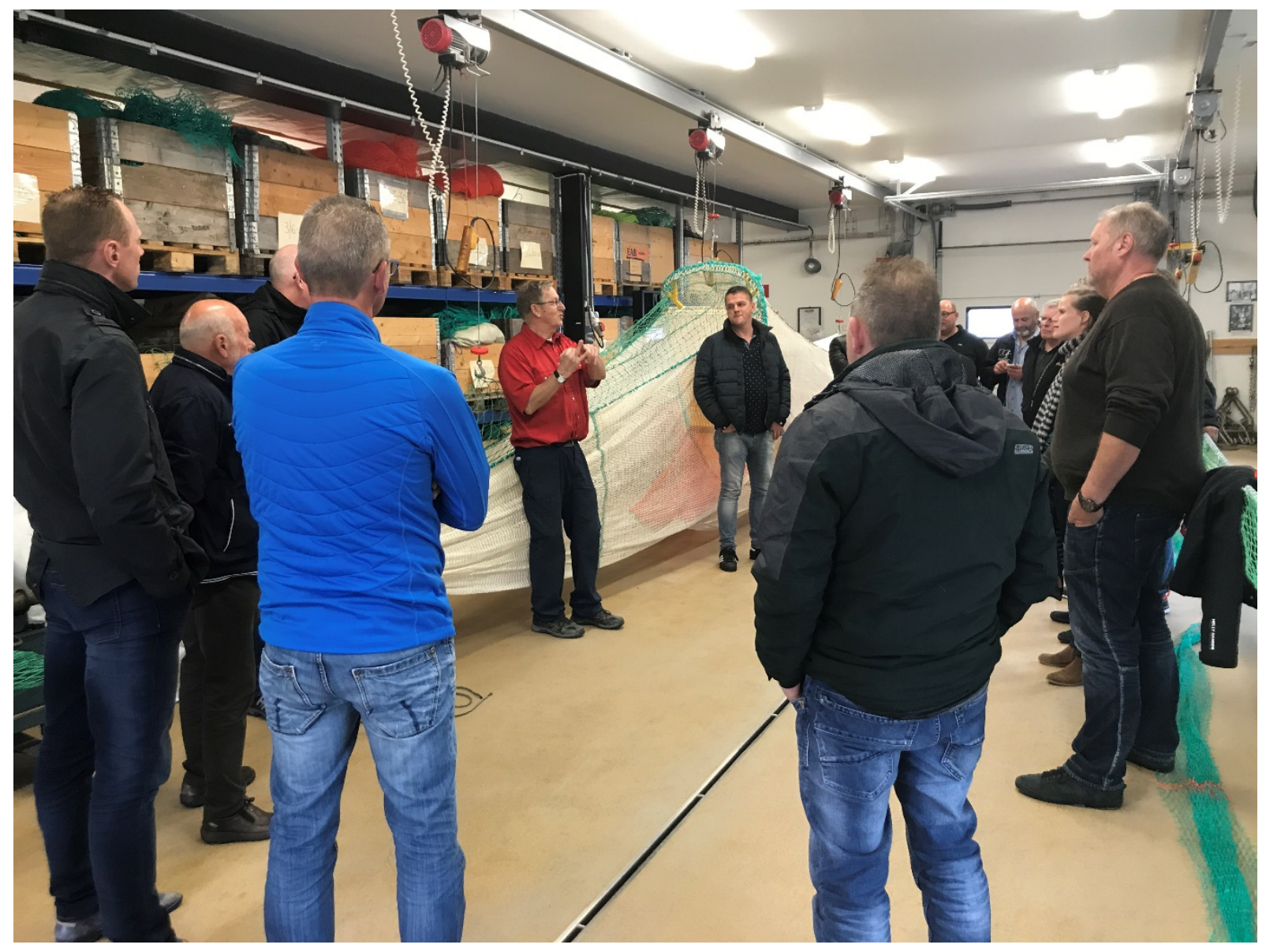

Foto 3 Uitleg over het Swedish grid bij nettenmakersbedrijf in Smögen.

De Nederlandse vissers en nettenmakers duiken op de opgehangen netten en bekijken alle details van de netten en bespreken onderling de mate van toepasbaarheid voor de Nederlandse visserij. Eén conclusie is dat het grid te groot is voor de Nederlandse langoustinevisserij, de Nederlandse netten zijn lager omdat hoger geen relevante doelsoorten zwemmen. We vertellen de Zweedse nettenmaker over het SepNep. Hij is er erg enthousiast over en wil het graag in de Zweedse context uitproberen.

\section{Visafslaq Smögen: grote levendige langoustines}

$\mathrm{Na}$ afloop van het bezoek zien we hoe een kotter binnenkomt die de met korven gevangen langoustines komt lossen op de afslag van Smögen. De Nederlanders zijn onder de indruk van de grootte van de langoustines en de levendigheid. Op de afslag van Smögen worden hoofdzakelijk garnalen en langoustines verhandeld, de afslag van Smögen is aangesloten bij PEFA.

Als afsluiter van het bezoek in Smögen proeven we de typisch Zweedse pandalus borealis, iedereen is het er over eens: een ware delicatesse. 


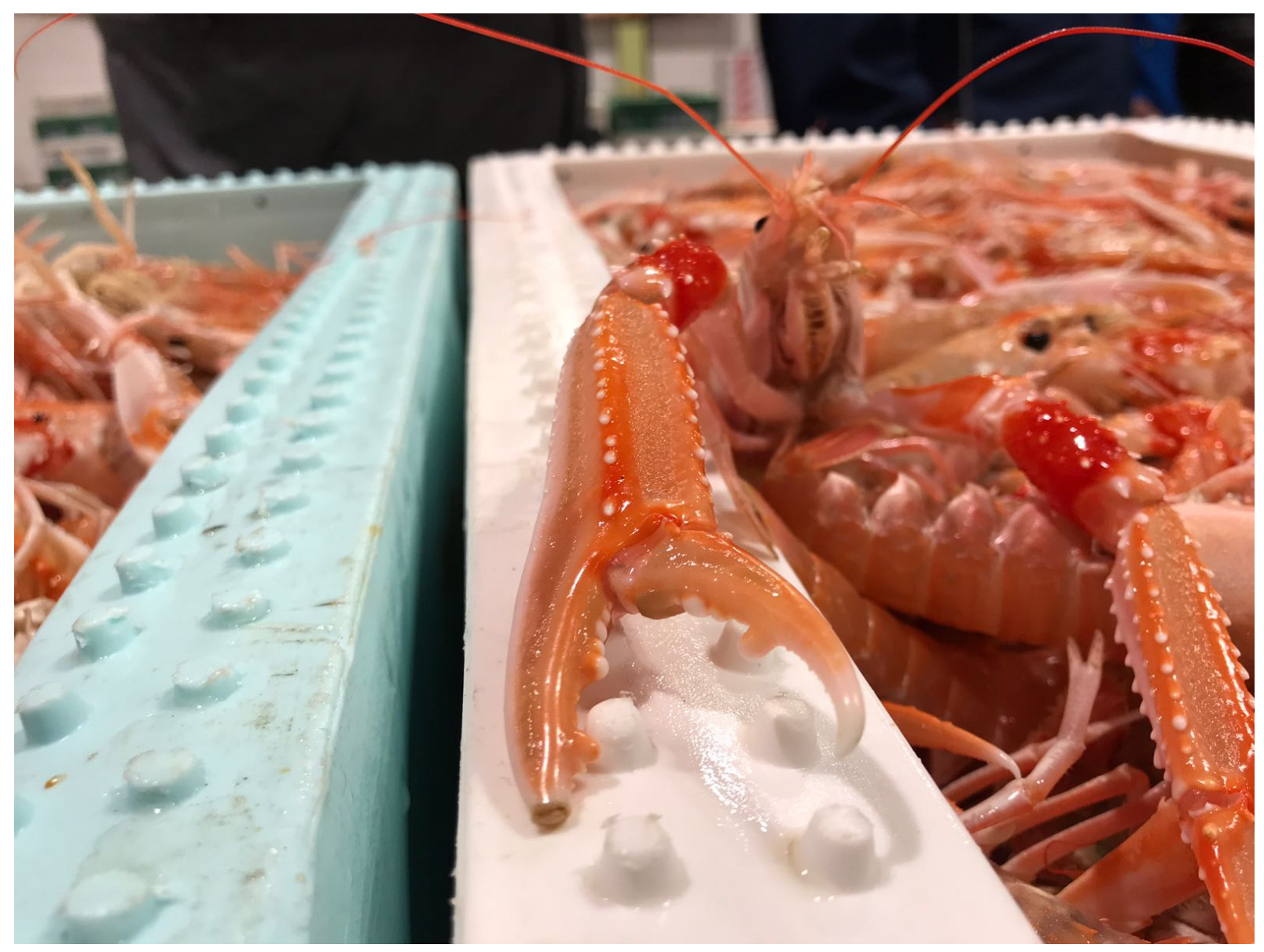

Foto 4 Grote levendige langoustines op de Zweedse visafslag.

\section{Dinsdagochtend vroeg: bezoek aan de visafslag}

Om 7 uur 's ochtends melden we ons bij de visafslag van Gotenburg, de grootste visafslag van Zweden waar vers aangelande demersale vis, zoetwatervis, langoustines en garnalen geveild worden. De visafslag is naast de visafslagen in Smögen en die in Stockholm, één van de drie Zweedse visafslagen. We krijgen er een rondleiding van Linda Hallberg van het onderwijscentrum dat bij de visafslag hoort. De kratten met vis staan in rijen opgesteld. Ze worden op de afslagvloer mondeling geveild door veilingmeesters. De handelaren staan er in een groepje omheen. Eerst gaat de veilingmeester vaak per tien kronen naar beneden tot een handelaar zijn hand opsteekt en daarna wordt vaak nog voor enkele kronen tegen elkaar op geboden. Oud-vissermannen uit de groep weten zich nog te herinneren dat het er op de afslag in IJmuiden vroeger ook zo aan toe ging. 


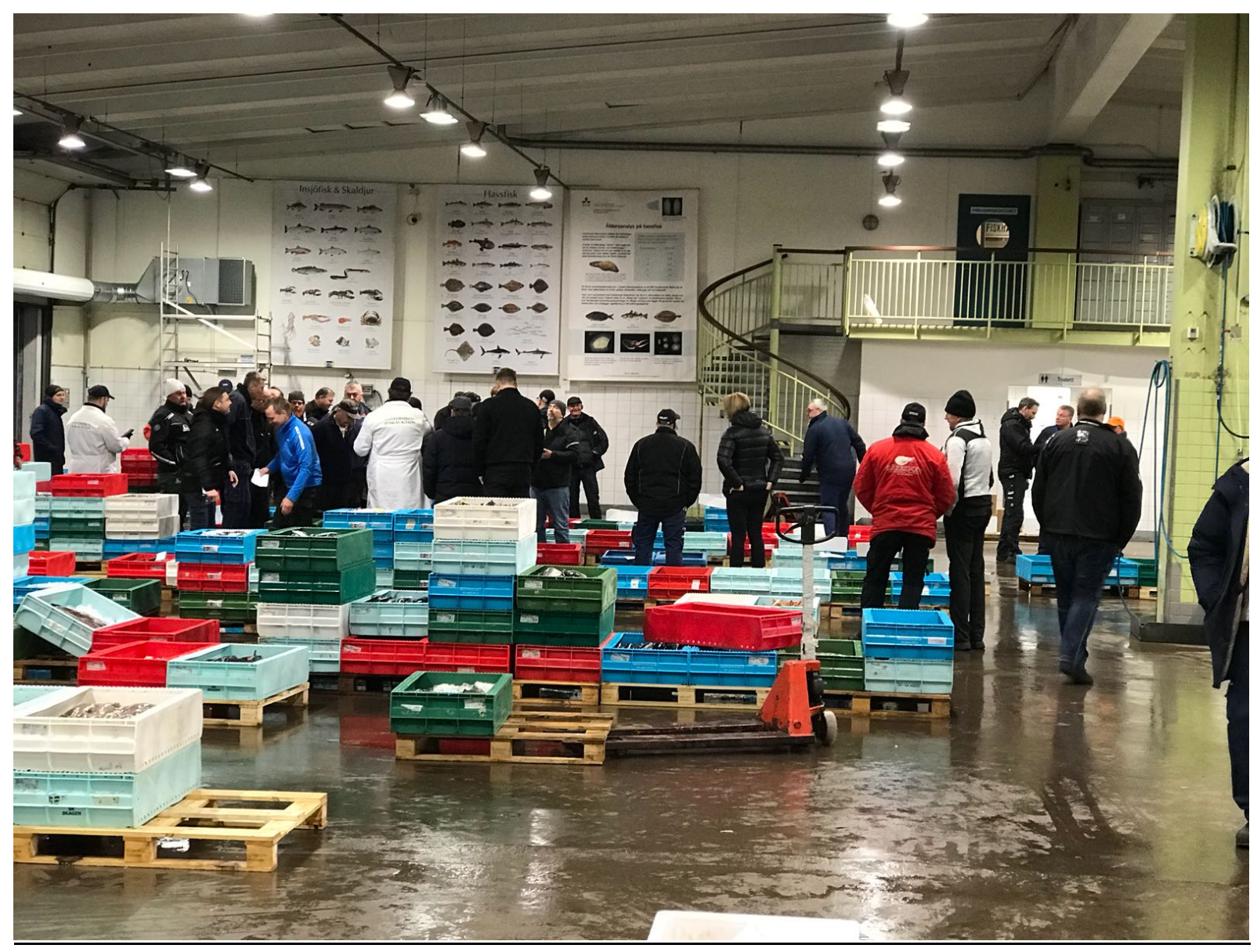

Foto 5 Vis en schaaldieren worden op de veilingvloer geveild.

\section{Nationale kwaliteitsmarkt}

We zien hier hoe de Zweedse visaanvoer veel minder is voor de bulkmarkt zoals in Nederland maar meer voor de nationale versmarkt. Verse vis wordt netjes in kisten gepresenteerd, vaak in kleinere hoeveelheden dan dat je op een Nederlandse visafslag ziet. Hallberg vertelt dat de Zweedse aanvoersector beschermend optreedt met betrekking tot de vismarkt en de visprijzen. Dit is goed te zien in hun reactie op het verlagen van de minimumaanvoermaat van langoustines uit het Skaggerak van 13 naar 10,5 cm. Het verlagen van de minimummaat was een verzoek van de Denen om de hoeveelheid langoustinediscards te reduceren. De aanvoersector levert de langoustines tussen de 10,5 en de $13 \mathrm{~cm}$ niet aan bij de afslag uit vrees dat dit de algehele prijs van langoustines doet zakken. In plaats daarvan verwerken ze deze kleine langoustines zelf in een coöperatieve fabriek waar ze gekookt worden en verkocht in emmers voor de retailmarkt. Dit sluit aan bij de Zweedse traditie om veel garnalen te eten.

\section{$\underline{\text { Vispromotie }}$}

In het onderwijscentrum geeft Hallberg uitleg over de Zweedse vispromotie. Op de afslag in Gotenburg worden rondleidingen en smaaklessen gegeven aan verschillende doelgroepen, zoals basisschoolleerlingen, zwangere vrouwen, studenten, sporters en bejaarden. Hierbij wordt uitgelegd hoe belangrijk vis in deze verschillende levensfases is voor de gezondheid.

De visafslag is in handen van de vissers (50\% aandeel), de handelaren (25\%), en de detailhandel (25\%).

\section{Dinsdagmiddag: uitwisseling met onderzoekers van SLU Aqua}


$\mathrm{Na}$ het bezoek aan de visafslag rijden we naar Lysekil waar het mariene onderzoek (Department of Aquatic Resources) van de Zweedse landbouwuniversiteit (SLU) zich bevindt. Hier krijgen we uitleg over het Zweedse netinnovatieonderzoek en over verschillende uitgeteste ontwerpen.

\section{Secretariaat voor selectieve visserii}

In Zweden is voor de periode 2014 - 2017 het Secretariaat voor Selectieve Visserij opgericht met als doel om selectievere netten te ontwikkelen in een samenwerking tussen de visserijsector en het onderzoek. Het secretariaat wordt gefinancierd uit nationaal Zweeds budget. Voor de periode 2014 - 2017 was hiervoor 38 miljoen Zweedse kronen beschikbaar en 7 miljoen voor de verlenging in 2018. De reden die genoemd wordt voor de nationale financiering was o.a. om een garantiebesomming te kunnen afspreken met schepen die deelnemen aan onderzoek, zodat deelnemende vissers niet zelf het risico lopen op inkomstenderving als resultaat van het uitvoeren van testen. Het secretariaat wordt gevoerd door het onderzoeksinstituut. Vissers kunnen hier ideeën inbrengen voor nieuwe netontwerpen waarna de onderzoekers samen met de vissers een onderzoeksvoorstel schrijven. Na goedkeuring van dit plan door het Swedish Agency for Marine and Water Management krijgen vissers gedurende twintig dagen de tijd om hun ontwerp uit te testen en te optimaliseren. Van te voren is een garantiebesomming afgesproken voor deze testperiode. Verdienen ze minder door de testen dan krijgen ze dit tot de garantiebesomming vergoed, verdienen ze dit bedrag of meer dan krijgen ze geen vergoeding. Als het netontwerp veelbelovend lijkt in de praktijk gaan er onderzoekers mee die data verzamelen om de werking van het net wetenschappelijk vast te stellen. Tot nu toe zijn er 34 netinnovatieprojecten vanuit het secretariaat uitgevoerd en drie zijn nog lopende.

Drie projecten worden in detail besproken, daarna worden nog enkele ontwerpen die getest zijn kort besproken.
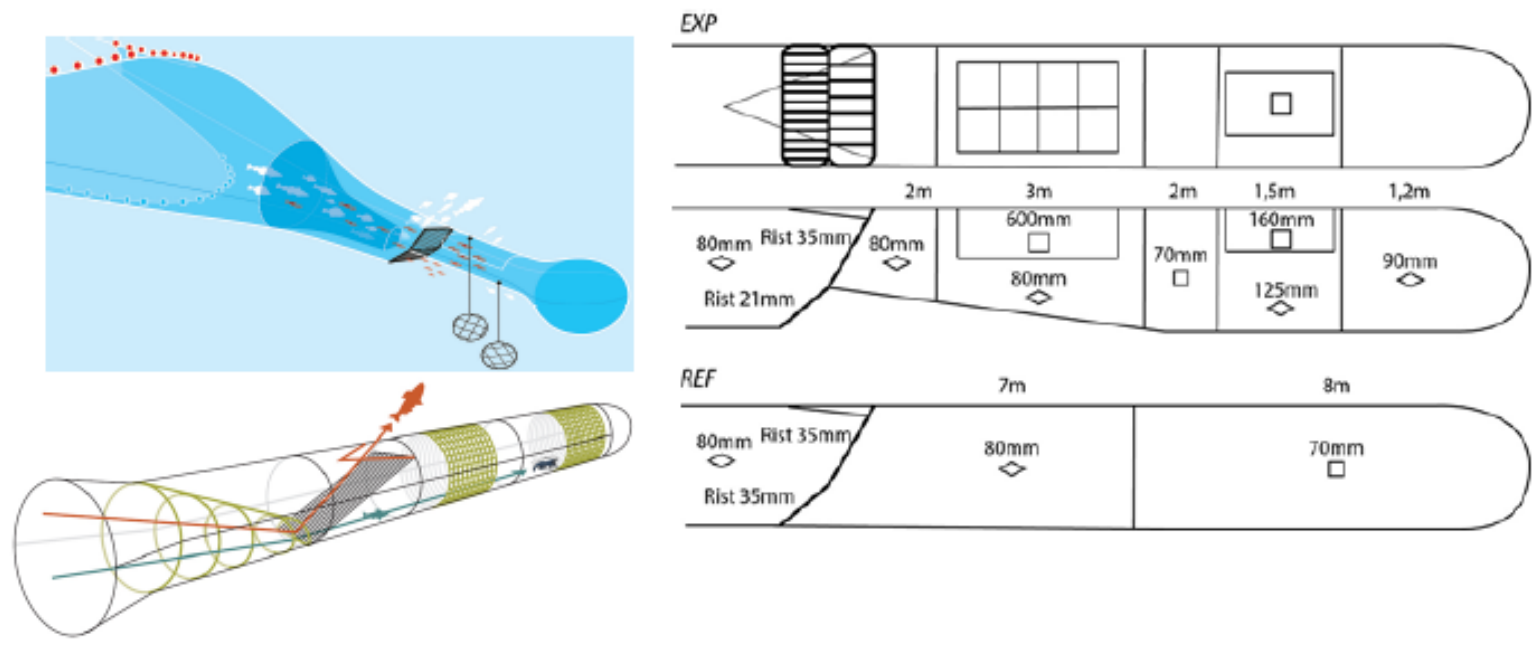

Figuur 43 verbeterd Swedish grid

Voorbeeld één gaat over het onderzoek om het Swedish grid te verbeteren zodat het nog beter ondermaatse langoustines en platvis van de maatse langoustines kan scheiden. De resultaten van het onderzoek waren goed. Het netontwerp is echter helaas niet in gebruik genomen vanwege de verlaging van de minimummaat voor langoustines, het was daardoor niet meer nodig om in het kader van de aanlandplicht de langoustines tussen de 10,5 en de 13 centimeter onder water te laten ontsnappen.

Andere toegelichte voorbeelden zijn een netontwerp voor de pelagische visserij, gericht op het laten ontsnappen van koolvis in de haringvisserij in het Skagerrak en een netontwerp gericht op het scheiden van platvis en rondvis om door middel van verschillende maaswijdtes te zorgen voor minder discards. Ook worden nog enkele experimentele netontwerpen voor de langoustinevisserij getoond. 
Het ontwerp: 'Low topless langoustine/Nephrops trawl' vangt minder kabeljauw in de langoustinevisserij, maar het blijft probleem dat de kabeljauw naar beneden wil.

Het ontwerp: 'Vertical trouser trawl for separating cod from haddock and saithe' creëerde een toename van kabeljauw in het lagere compartiment, maar de rest van de ongewenst bijvangst nam af in de langoustine visserij.

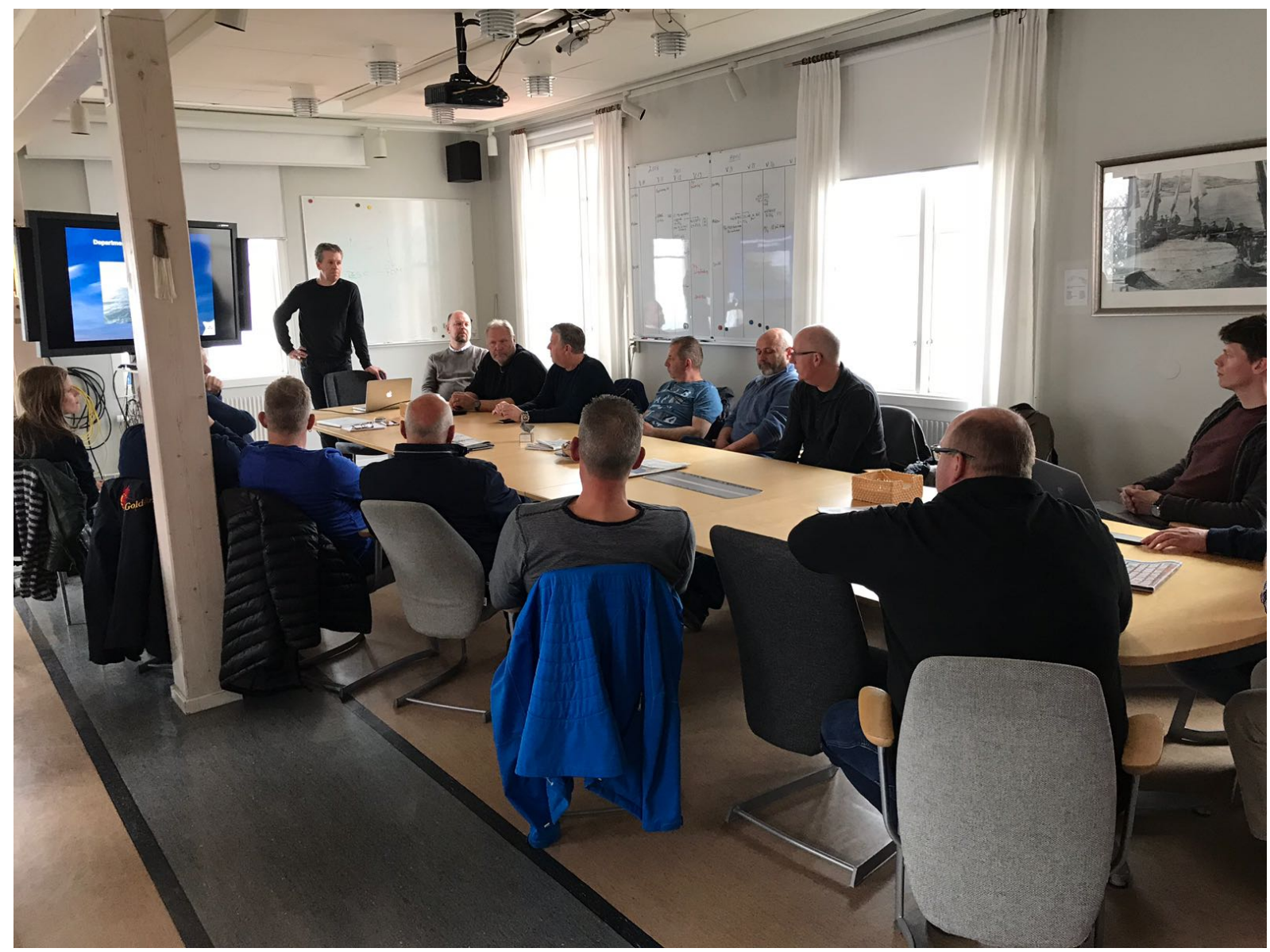

Foto 6 In gesprek met de Zweedse onderzoekers van het Department of Aquatic Resources (SLU Aqua).

De afgeronde en lopende Nederlandse netinnovatieonderzoeken worden door Brita van den DriesTrapman aan de Zweedse onderzoekers toegelicht. De informatie wordt aangevuld door de Nederlandse vissers en nettenmakers die zelf actieve deelnemers zijn in de verschillende onderzoeken. De onderzoekers en Zweedse PO-vertegenwoordigers die ook mee zijn nemen met interesse kennis van de Nederlandse onderzoeken. De Zweedse PO-voorman spreekt het voornemen uit om ook in de Zweedse context het SepNep te gaan uittesten. Op het idee van de WR 274 om in de langoustinevisserij met fish herding lines te werken (deze lijnen verjagen de vis voor het langoustinenet waardoor er minder maatse en ondermaatse vis wordt gevangen) reageert Peter Olssen dat hij verwacht dat er meer langoustines gevangen zullen worden. Hiermee bevestigt hij de verwachting van de Nederlandse vissers en nettenmakers.

\section{Zinvolle uitwisseling}

Vanuit beide kanten wordt er positief gereageerd op elkaars ideeën en de betrokkenen van beide kanten zijn blij met de uitwisseling van elkaars netinnovaties. Geconcludeerd kan worden dat Zweden en Nederland veel van elkaar kunnen leren op het gebied van de langoustinevisserij. Wat de platvisvisserij betreft, heeft Zweden niet een vergelijkbare gerichte visserij op schol of tong. Waar het in Zweden van belang is om rondvis en platvis van elkaar te kunnen scheiden, staat Nederland voor de uitdaging om verschillende types platvis van elkaar te scheiden. Bijvoorbeeld schol en tong in de pulsvisserij of rog van schol, tarbot en griet in de gerichte visserij op schol. 
Op woensdagochtend delen de deelnemers met elkaar in een eindgesprek de indrukken van de afgelopen dagen:

- In Zweden zijn ze op een zelfde manier aan de slag met het netinnovatie in de langoustinevisserij en lopen ze tegen vergelijkbare problemen aan.

- De vispromotie in Zweden is inspirerend en goed voor elkaar.

- De compensatie van netonderzoek op zee door vissers is goed geregeld met de garantiebesomming. De groep besluit de beleidsmaker die invulling geeft aan de $15 \mathrm{~m}$ uit het regeerakkoord voor visinnovatieonderzoek per brief te informeren over het Zweedse secretariaat voor selectieve visserij, als inspirerend voorbeeld waar Nederland mogelijk een voorbeeld aan kan nemen. De bemanning van een experimenterend schip moet niet lijden onder het onderzoek in de vorm van kosten, dit kan namelijk de uitkomsten van het onderzoek beïnvloeden omdat er minder motivatie is en mogelijk minder doorzettingsvermogen is om een ontwerp te laten slagen.

- Het Swedish grid wordt meer in de praktijk gebruikt dan van te voren door deelnemers verwacht. Enkele deelnemers zijn voornemens dit grid verder te ontwikkelen voor de Nederlandse praktijk, als extra optie naast het SepNep. Het Swedish grid kan in Nederland relevant zijn voor zowel de langoustine- als voor de garnalenvisserij. Van groot belang is om de juiste positie van het grid te bepalen. In Zweden wordt een metalen grid gebruikt. Dit in verband met de grote hoeveelheid stenen op de visgronden die een plastic grid makkelijk beschadigen en omdat het makkelijker te repareren is dan een plastic grid. In Nederland is een plastic grid mogelijk wel goed toe te passen.

- Het voorbeeld van het niet in gebruik nemen van het verbeterde Swedish grid laat zien hoe belangrijk regelgeving is voor het wel of niet in gebruik nemen van bepaalde selectievere vistuigen.

- Voor de meeste Nederlandse problemen in de gerichte platvisvisserij is in Zweden geen oplossing of voorbeeld te vinden dat kan leiden tot een oplossing. Mogelijk dat er voor het onder water vrij laten van wijting gekeken kan worden naar de Zweedse onderzoeken om rondvis van platvis te scheiden.

- De Zweedse aanvoersector bedient meer een markt waar versheid voorop staat terwijl de Nederlandse aanvoersector meer een bulkmarkt bedient, dat resulteert in een verschillend soort visserijgedrag.

- De groep constateert dat de Zweden goed voor hun bestanden zorgen en bespreekt dat het beter zou zijn als door Nederlandse vissers geen kreeftjes meegenomen worden met een stukstal onder de 35 stuks per kilo. Maar hoe dit voor elkaar te krijgen? (suggesties die worden gedaan: elkaar erop aanspreken; Speciaal soort keurmerk wat het verhaal vertelt; PO-maatregel; Knop om bij de visserman; Een manier vinden om er zelf meer voordeel uit te halen.)

Voor vertrek naar de luchthaven bedanken de Nederlanders de Zweden voor hun gastvrijheid en wordt vanuit beide kanten benadrukt dat het een interessante, relevante uitwisseling was die voor herhaling vatbaar is, volgende keer in Nederland. 


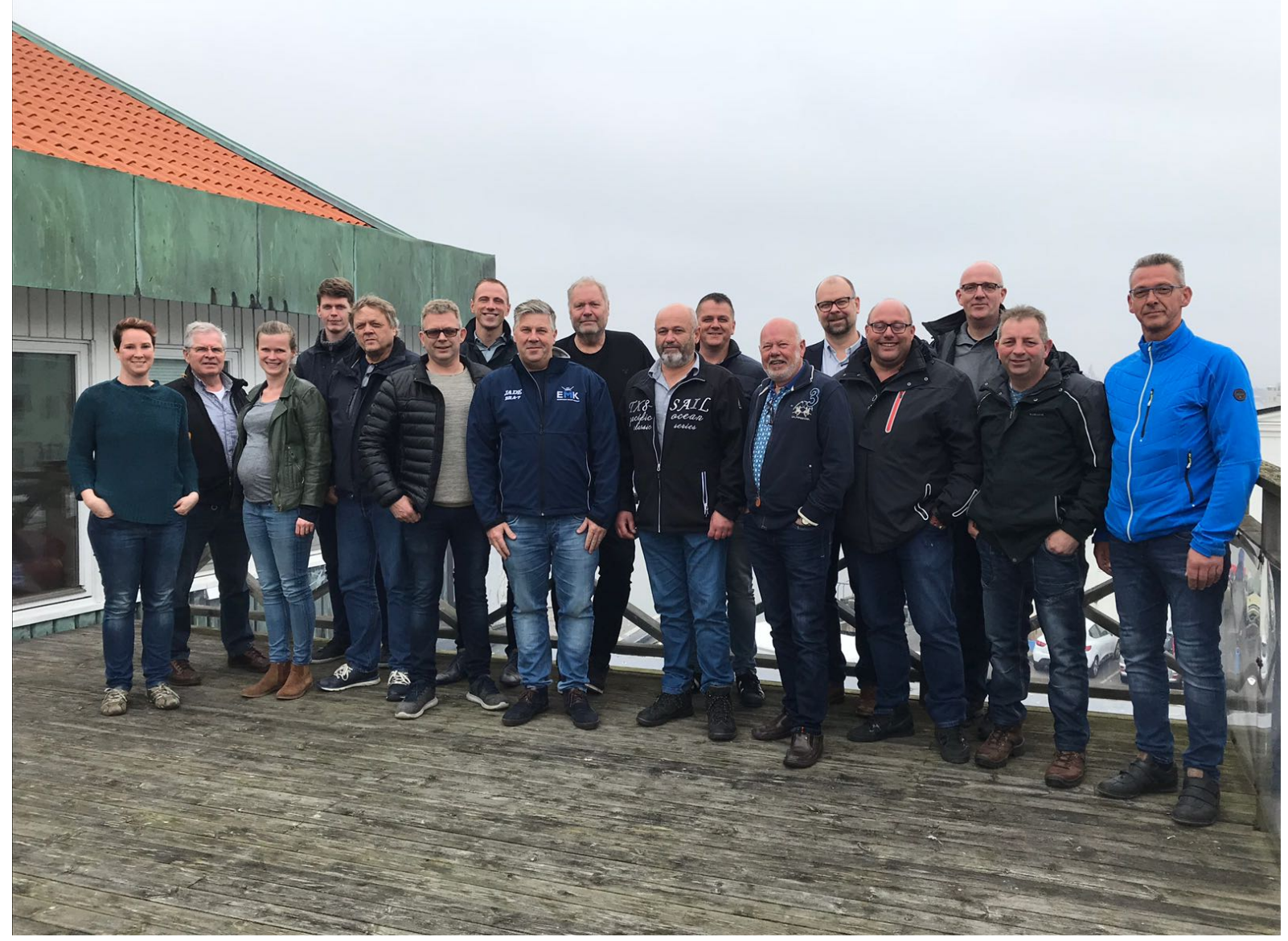

Foto 7 Groepsfoto met alle Nederlandse deelnemers en drie Zweedse visserijvertegenwoordigers.

Appendix: deelnemers aan de reis

\begin{tabular}{|l|l|l|l|}
\hline Achternaam & Voornaam & Organisatie & Visserij \\
\hline de Visser & Adriaan & WR 108 & Noorse kreeft \\
\hline Kraak & Dirk & BRA 5/BRA 7 & Noorse kreeft/tong \\
\hline Zomerdijk & John Mark & WR 274 & Noorse kreeft \\
\hline van Eekelen & Kees & WR 189 & Noorse kreeft \\
\hline ten Bokkel & René & N 350 & Noorse kreeft \\
\hline Lokker & Arie & CIV Westvoorn & Flyshoot/scholvisserij \\
\hline Trapman & Brita & Nederlandse Vissersbond & Projectleider en reisleider \\
\hline van Wijck & Charles & CIV Den Oever & Noorse kreeft \\
\hline Meijer & Dries & NG 21 & Noorse kreeft \\
\hline van Linden & Eric & Rederij Jaczon & Scholvisserij/flyshoot/tongvisserij \\
\hline Landstra & Florian & Nederlandse Vissersbond & Vervangend projectleider \\
\hline Vlaming & Jaap & $\begin{array}{l}\text { Visserijconsultant } \\
\text { (nettenmaker) }\end{array}$ & Noorse kreeft/tongvisserij \\
\hline Snoek & Jacob & Nederlandse Vissersbond & Projectmedewerker \\
\hline van Rijswijk & Sander & $\begin{array}{l}\text { CIV Den Oever } \\
\text { (nettenmaker) }\end{array}$ & Noorse kreeft/tongvisserij \\
\hline
\end{tabular}




\section{Bijlage 9: Flyshoot: Overzicht literatuur wijting}

The vertical separation of fish in the aft end of a demersal trawl Krag et al. (2009)

Two multi-compartment separator frames in extension were used to study the vertical separation of some commercially important fish species in the aft end of a trawl, with aim on cod. Net was separated in lower part (LOW, $<32.5 \mathrm{~cm}$ ), middle part (MID, $32.5<\mathrm{x}<0.75 \mathrm{~m}$ ) and upper part (UP, $>0.75$ )

\section{Conclusions}

- Vertical distribution of cod was close to uniform, whereas whiting, haddock, plaice and lemon sole showed more uneven distributions

- The use of guiding bars significantly increases the catch of cod, plaice and lemon sole in the upper compartment

- Vertical separation of cod was density-dependent. High densities of fish resulted in a more uniform distribution of cod

\section{Other info}

Whiting and saithe enter trawl above groundgear, higher up

Cod, flatfish and nephrops enters close to groundgear

wijting zat $81 \%$ in bovenste deel (UP, $>0.75 \mathrm{~m}), 8 \%$ midden $(0.325 \mathrm{~m}>x>0.75 \mathrm{~m}), 1 \%$ low $(<32.5)$

Rest:

Table 1. Estimated conditional catch proportions for the three compartments in the simple separator frame and in the complex separator frame, by species.

\begin{tabular}{|c|c|c|c|c|c|}
\hline \multirow[b]{2}{*}{ Species } & \multirow[b]{2}{*}{ Compartment } & \multicolumn{2}{|c|}{ Simple frame } & \multicolumn{2}{|c|}{ Complex frame } \\
\hline & & Estimate & s.e. & Estimate & s.e. \\
\hline \multirow[t]{3}{*}{ Cod } & Upper & 0.540 & 0.051 & 0.671 & 0.044 \\
\hline & Middle & 0.282 & 0.033 & 0.194 & 0.027 \\
\hline & Lower & 0.178 & 0.021 & 0.136 & 0.019 \\
\hline \multirow[t]{3}{*}{ Haddock } & Upper & 0.872 & 0.088 & 0.777 & 0.075 \\
\hline & Middle & 0.088 & 0.061 & 0.151 & 0.055 \\
\hline & Lower & 0.040 & 0.028 & 0.072 & 0.026 \\
\hline \multirow[t]{3}{*}{ Whiting } & Upper & 0.906 & 0.029 & 0.951 & 0.011 \\
\hline & Middle & 0.082 & 0.027 & 0.038 & 0.009 \\
\hline & Lower & 0.011 & 0.003 & 0.011 & 0.003 \\
\hline \multirow[t]{3}{*}{ Plaice } & Upper & 0.268 & 0.033 & 0.538 & 0.069 \\
\hline & Middle & 0.265 & 0.026 & 0.209 & 0.041 \\
\hline & Lower & 0.468 & 0.031 & 0.253 & 0.043 \\
\hline \multirow[t]{3}{*}{ Lemon sole } & Upper & 0.326 & 0.042 & 0.502 & 0.038 \\
\hline & Middle & 0.385 & 0.027 & 0.305 & 0.027 \\
\hline & Lower & 0.289 & 0.021 & 0.194 & 0.018 \\
\hline
\end{tabular}

Model 1 was used to estimate the catch proportions. s.e., standard error.

- Giding bars (complex frame) increase the proportion of whiting, but also of flatfish in the upper part of the trawl.

- A significant greater proportion of cod, plaice and lemon sole entered the lower compartment by day than by night

- $\quad$ The rising behavior of gadoids in the catching process appeared to be more pronounced during daylight

Take home for NIKO II

- Schelvis en wijting vertonen gelijkaardige verdeling in net 
Square mesh tube zoals in vorige paper is weinig zinvol want wijting zit toch bijna allemaal van boven. Eventueel kan square mesh section wel verlaagd worden tot aan rijging. Lager heeft geen zin en zal enkel nodeloos verlies betekenen

- Geleiders jagen ook platvis (en mogelijks ook mul en poon) omhoog, waar we ze niet willen als daar de scheiding plaatsvind met SMP. Ofwel dus beperkt aantal geleiders die breder zijn boven de helft, ofwel systeem maken dat pas boven $30 \mathrm{~cm}$ aanvangt zodat bodemzoekers er sowieso onder gaan.

Improving gear selectivity of whiting on board French demersal trawlers in the English Channel and North Sea Vogel et al. (2017)

Square mesh panels (SMP), square mesh cilinders (SMC, square mesh netting all around the net) and grids were tested.

\section{Conclusions}

- $80 \mathrm{~mm}$ SMP was efficient at letting undersized whiting escape from the trawl. Its efficiency was enchanced when it was positioned 6-9 m ahead of codline compared with that placed 12$15 \mathrm{~m}$ ahead of it

Most appropriate bar spacing for whiting size-selective flexigrid was $23 \mathrm{~mm}$

- $\quad$ Best results with $80 \mathrm{~mm}$ SMC of $2 \mathrm{~m}$ long, allowed significant escapes of fish up to $25 \mathrm{~cm}$ in length.

\section{Other info}

- Whiting is known to rise to the top part of the extension and codend section, with good escape success if the fish makes contact with the netting.

- $\quad$ SMP is mandatory in the dorsal extension piece of trawls $>18 \mathrm{~m}$ working in the North Sea and Southern Bight

Undersized discarded whiting have limited survival capacity due to their low stress tolerance Whiting escape appears to be unaffected by the time of day

Increasing the mesh size of SMP from mandatory $80 \mathrm{~mm}$ to $120 \mathrm{~mm}$ square mesh does not benefit small individuals, which would escape through the existing $80 \mathrm{~mm}$ anyway but instead allow more commercial fish to escape

- A SMP in the tapered section (kegel naar start toe) does NOT increase escape probabilities for whiting

Double grid system was successful but increases escape over whole length range

\section{Take home for NIKO II}

Niet nuttig van maasgrootte van paneel groter te maken dan $80 \mathrm{~mm}$

Hoe meer naar achter, hoe effectiever paneel (moet natuurlijk wel voor de accumulatie zone van de vangst blijven)

\section{Separating species using a horizontal panel in the Scottish North Sea whitefish trawl fishery Ferro et al. (2007)}

Horizontaal scheidingspaneel op 1.1 (center) - 1.9 (hoeken) m van de buik van de staart in bordennet. Akoestische observatie van visgedrag en locatie

\section{Conclusions}

- Most haddock, whiting and saith pass above panel whereas most cod, flatfish and monkfish pass below it.

- Towing speed and panel length had no significant effect on separation

- $\quad$ At lower light (night), fewer dab, sole, plaice and cod pass below the panel.

- $\quad$ Height at which fish enter the net mouth may be influenced by light level and water clarity.

\section{Other info}

$67-95 \%$ wijting erboven: gemiddeld gezien dus $80 \%$ hoger dan $1.1 \mathrm{~m}, 20 \%$ eronder

$80-90 \%$ van schelvis erboven, $85-95 \%$ van koolvis erboven, slechts $10-15 \%$ kabeljauw erboven

5-15\% tongschar erboven, $10-20 \%$ pladijs erboven, $0-46 \%$ schar erboven

Significant meer kabeljauw en platvis onderaan in het net overdag dan snachts

No effect of towing speed

- $\quad$ No significant difference in separation between panel starting at $11 \mathrm{~m}$ and at $19.5 \mathrm{~m}$

\section{Take home}

Sleepsnelheid heeft niet zoveel effect op scheiding, we kunnen dus verwachten dat de scheiding gelijkaardig is tijdens het gehele verloop van het vangstproces in flyshoot 
Hoe klaarder de omstandigheden, hoe meer platvis en kabeljauw de neiging zal hebben om laag te blijven, dus hoe beter de scheiding. Mogelijks op termijn met extra selectieve netaanpassingen voor wijting het beste effect dus in heldere omstandigheden.

\section{Estimating escapement of fish and invertebrates in a Danish anchor seine} Noack et al. (2017)

By attaching 12 small mesheed collecting bags to different parts of a Danish anchor seine net the authors made a estimate of the escapement of fish and invertebrates in different parts of the trawl

\section{Conclusion}

- Most invertebrates escaped through the netting in the lower forward sections of the seine net and only a small proportion of the invertebrates that entered the seine net ended up in the codend.

\section{Video recordings in other papers of Thomas Noacks phd thesis}

- Majority of the fish enters the net within the last quarter of the fishing process

\section{A meta-analysis of vertical stratification in demersal trawl gears Fryer et al. (2017)}

Meta-analyse van tal van rapporten en papers met scheidings panelen.

\section{Conclusie}

- Cod is the only species for which separation depends on the horizontal distance of the leading edge of the panel from the ground gear, with the proportion of cod going above of the panel increasing the farther the panel is from the ground gear.

- The time of the day only affects the separation of plaice, with a greater proportion going above the panel at night than during the day

\section{Other info}

- Wijting vlucht ook horizontal (in het hoogste deel van trawl), terwijl schelvis enkel omhoog kijkt.

- Whiting, who initially swim slightly higher off the seabed than haddock at about 1-2 m, do not tend to rise, but turn in the horizontal plane as they drop back.

Holst et al (2009) concluded that cod are close to the belly sheet when they first enter the gear but have redistributed upwards by the time they arrive at the extension.

Haddock, whiting and saithe are easily separated $>1 \mathrm{~m}$

Cod, lemon sole, plaice are most often in the zone between 0.2 and $1.5 \mathrm{~m}$ monkfish \& nephrops are randomly distributed

- In dark conditions, flatfish were more likely to rise off the bottom in response to an oncoming footrope, whereas in the light they tended to swim away from the footrope and remain close to the seabed

\section{Take Home Message}

- Horizontal ontsnappingsgedrag van wijting (in bovenste stuk van trawl) verklaart waarom de square mesh cylinder meer ondermaatse wijting kwijtspeelde dan een paneel in de rug. Afhankelijk van gedrag van makreel en mul kunnen vierkantmazige ontsnappingsvensters tussen de rijging en de top van de rug van het net mogelijks veel ondermaatse wijting lozen zonder aanzienlijk verlies van de commercieel belangrijke soorten

\section{Report of the 275 cruise RV Clupea October 2013- Effectiveness of Square Mesh Windows (SMW) in upper side of the netJuan Santos \& co, Thünen Institut, 2013.}

Different set ups and configurations of ropes with floaters were tested in combination with a SMW and the effect on the behavior of animals was tested

\section{Conclusion}

Fish only escape through SMW if they effectively contact it

Video observation shows that most fish just drift backwards without making contact with the SMW/escaping

Lower tunnel increases the chances of making contact with the SMW and thus the chance on escapement

- The ropes with floaters should vibrate well in order to initiate a good escape response and increased chance on contact with SMW 


\section{Documentation}

Setup 1= SMW without ropes \& floater; Setup 2 = SMW with single strings of ropes with floaters;

Setup 3 = SMW with $\wedge$ or $M$ shaped ropes with floaters attached to belly

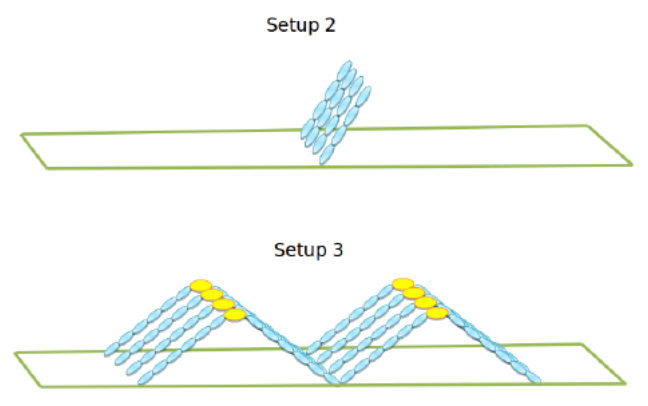

Figure 3: Schematic side view of the stimulating ropes configurations used in setup 2 and setup 3 .
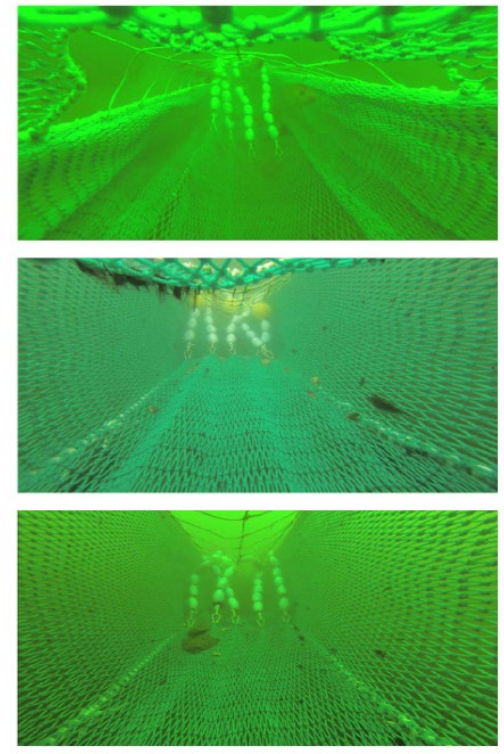

Figure 2: Entanglement problems found for most configurations tested in setup stage
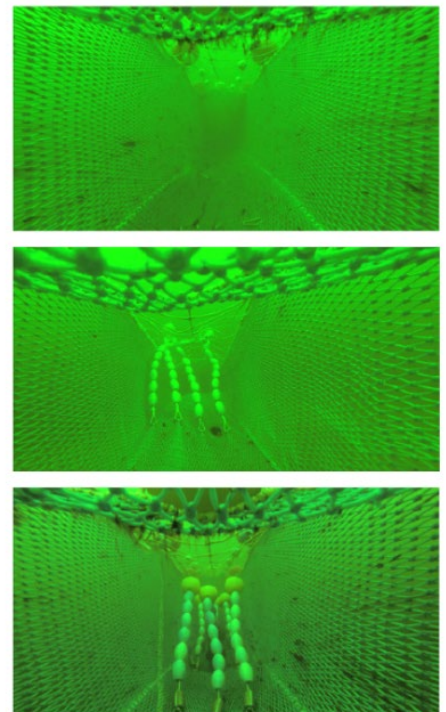

igure 4: UW images showing frontal view of setup 1 (top) setup 2 (center) and setup 3 (bottom) entral image shows setup 2 performance was affected by entanglement problems.

\section{Results}

Setup 1 (just SMW): 15\% loss of whiting

- $\quad$ Setup 2 (SMW + single ropes with floaters): $62 \%$ loss of whiting

- $\quad$ Setup 3 (SMW + ^or M shaped rope configuration): $46 \%$ loss of whiting

- No useful information on behavior of mackerel

\section{Take home message}

Additional stimuli needed to promote escape behavior and achieve good selectivity of SMW

- Setup 2 (5 separate ropes with floaters) give the best result to stimulate whiting and make the majority of the small individuals escape. However, entanglement can occur.

- Uiteindes van ropes fixeren met stuk touw om verstrengeling te voorkomen of een flap fijnmazig net met floaters gebruiken zodat verstrengeling niet optreed.

- Stuk net dat 0.3-0.5 m boven de buik van het net begint met vlotters eraan lijkt ideaal: geen verstrengeling, wel afschrikking van wijting naar boven door paneel en minimale beïnvloeding van platvis en hopelijk mul en poon zodat die laag blijft en eronder door gaat. 


\begin{tabular}{|c|c|c|c|c|c|}
\hline Setup & Species (DE) & Species (EN) & Test & Reference & Ratio \\
\hline \multirow{12}{*}{ setup1 } & aalmutter & eelpout & 0.34 & 0.64 & $53.1(0-\operatorname{Inf})$ \\
\hline & dorsch & $\operatorname{cod}$ & 618.46 & 838.54 & $75.4(64.2-92.3)$ \\
\hline & flunder & flounder & 1657.52 & 1887.42 & $87.4(76.2-96.4)$ \\
\hline & hering & herring & 7.40 & 24.12 & $31(13-54.5)$ \\
\hline & kliesche & dab & 300.99 & 332.27 & $91(76-113.5)$ \\
\hline & makrele & mackerel & 1.42 & 0.77 & $184.4(80.5-475)$ \\
\hline & scholle & plaice & 78.92 & 102.80 & $77.7(51.2-107.7)$ \\
\hline & seehase & henfish & 0.00 & 0.42 & $0(0-0)$ \\
\hline & seeskorpion & - & 3.13 & 2.33 & $142(68.2-252.5)$ \\
\hline & steinbutt & turbot & 44.18 & 65.14 & $68.6(47.2-93.3)$ \\
\hline & stint & - & 2.64 & 5.98 & $45.3(0-86)$ \\
\hline & wittling & whiting & 140.85 & 165.08 & $84.8(60.7-107.3)$ \\
\hline \multirow{11}{*}{ setup2 } & dorsch & $\operatorname{cod}$ & 44.34 & 160.98 & $35(18.1-71.5)$ \\
\hline & flunder & flounder & 112.74 & 194.86 & $57.3(50.2-61)$ \\
\hline & hering & herring & 0.00 & 3.56 & $0(0-0)$ \\
\hline & kliesche & dab & 75.42 & 89.78 & $84.5(78.5-93.3)$ \\
\hline & makrele & mackerel & 0.00 & 0.36 & $0(0-0)$ \\
\hline & scholle & plaice & 19.58 & 12.98 & $148.1(47.2-222.8)$ \\
\hline & seeskorpion & & 0.20 & 0.24 & $83.3(0-\operatorname{Inf})$ \\
\hline & steinbutt & turbot & 5.92 & 6.72 & $86.1(31.8-171.6)$ \\
\hline & wittling & whiting & 5.76 & 18.32 & $37.6(27.4-76.1)$ \\
\hline & aalmutter & eelpout & 3.26 & 0.18 & 1811.1 (255.6-Inf) \\
\hline & dorsch & $\operatorname{cod}$ & 257.47 & 347.42 & $73.6(56.8-89.9)$ \\
\hline \multirow{7}{*}{ setup3 } & flunder & flounder & 396.13 & 507.98 & $79.8(54.7-106.8)$ \\
\hline & hering & herring & 3.60 & 18.12 & $22.2(8.8-54.5)$ \\
\hline & kliesche & dab & 247.96 & 291.71 & $85.5(73.4-101.2)$ \\
\hline & scholle & plaice & 40.21 & 43.59 & $91.9(66.9-121.1)$ \\
\hline & seeskorpion & - & 1.86 & 2.24 & $95.1(35.3-210.1)$ \\
\hline & steinbutt & turbot & 39.12 & 47.12 & $83.3(51.7-119.7)$ \\
\hline & wittling & whiting & 46.02 & 87.40 & $53.9(40.1-73.8)$ \\
\hline
\end{tabular}

Table 2: Pooled catch (Kilo) information for the test and the reference gears, and associated cat (estimated as $\frac{n_{t}}{n_{r}}$ ) by species and experimental setups. Bootstrap CI of catch ratio in brackets. 


\section{Bijlage 10: Flyshoot: observaties onderwaterbeelden}

\section{i. Waarnemingen $\mathrm{SCH} 135$ april 2018}

\section{Set-up met rode touwen voor paneel van buik naar rug + wit loodtouw aan rug thv einde paneel + overkuil}

\section{Trek 2: paneel staat volledig scheef en wordt samengetrokken}

Camera in buik naar achter:

Camera in buik onder paneel omhoog: camera wat gedraaid waardoor zicht op rijging ipv paneel, net niet mooi open door kuil waardoor rug te dicht op camera zit en je weinig overzicht hebt.

Camera aan rug naar achter: kijkt schuin door het paneel omhoog. Geen ontsnapping, zegt weinig.

- $\quad 2 a, 2 b$ en $2 c$ : verschillende stappen van proces en wijting en co onder paneel

- 2a: weinig vis, net nog toe. Platvis die opwaards probeert te ontsnappen

- 2b: meeste wijting bovenaan. Opwaardse ontsnapping, maar ook zijdelings door plooi van net, zeker bij hogere snelheden (2c)

2d: inktvis gaat in rechte lijn en lijkt altijd onder paneel door te gaan (bevestigd in vangstanalyse) of zich tijdelijk vast te haken. Hier kwade reactie $v \mathrm{mr}$ inktvis.

\section{Trek 3: rug deze keer wel mooi open}

\section{Camera aan rug naar achter:}

S10 tot s40: opengaan net: wijting etc komt als 1 grote bal binnen en DAN pas gaat het net open. Weinig mogelijkheden tot scheiden tot dan. Daarna snel veel vis. (3a)

- $\quad 8.20$ tot 8.30: wijting rustig mee met stroom, onder paneel, geen reactie tov loodtouw achteraan in beeld (3b)

10.10 tot 10.20 : haring voor loodtouw (geen reactie merkbaar) onder paneel (3c)

- $\quad$ S 4 tot 44 van $2^{\mathrm{e}}$ deel: zeebaars en kabeljauw reageren niet echt op loodtouw bij halen net (3d)

Camera in rug naar voor:

- Min 8 to t8.10: haring die binnenkomt en traag voor en rond rode touwen zwemt. Geen ontwijkingsgedrag merkbaar $\left(3^{\mathrm{e}}\right)$

- $\quad$ Min 13.20 tot 13.30: haring die snel blijft zwemmen en voor schiet bij stoppen halen (3f)

Camera in buik onder paneel omhoog:

- Geen meerwaarde

\section{Set-up met rode touwen voor paneel van buik naar rug + wit loodtouw aan rug thv einde paneel + overkuil}

\section{Trek 4: zonder overkuil}

Camera in buik onder paneel omhoog:

- Min 4.10: veel passerende vis, zicht op paneel zonder bovenkuil langs onder op einde. (4a)

Camera aan rug naar achter:

- $\quad$ Min 13 en volgende: wijting aan loodtouw. Donkerder beeld, opnieuw weinig effect op gedrag. Beeld niet geknipt.

- 5 min later ( begin $2^{e}$ fragment): haring komt binnen. Geen effect van touwtjes, zeer weinig ontsnapping door paneel!

- Helemaal op einde: vangst die weer naar voor schuift bij uitpikken (4b), maar weinig extra ontsnapping

Camera in rug naar voor:

- Min14: wijting achter rode touwen. Het remt enigszins de vlotte doorgang als ze terug willen zwemmen, maar als ze echt willen geen probleem. $10 \%$ ontsnapping door paneel 
- Begin volgende filmpje: massas haring die binnenkomt, geen merkbaar effect van touwen, ontsnapping moeilijk in te schatten maar lijkt klein (4c)

Camera achter bovenpees naar beneden

- $\quad$ Te hoog voor scherp beeld, wel mooi beeld van zich sluitende onderpees (zie foto's)

Camera achter grondpees naar voor:

- $\quad$ Een grote soep, camera vaak gedraaid, veel net te zien maar weinig vis

\section{Trek 5: zonder overkuil}

Camera in rug naar voor:

- $\quad$ Staart blijft lang toeliggen. Je ziet heel wat kabeljauw over het net passeren (probleem met bovenpees waardoor vis erover en slechte waterdoorstroming?) Duidelijk anders dan trek 3 waar vis als bal binnenkwam. (5a). Duidelijk hoge \% ontsnapping als opening smal is en ze veel/makkelijk contact maken!

Ontsnapping van wijting zou verder verbeterd kunnen worden door staart lager te maken!

- Later in de trek wel normaal open (zie filmpje 5b en 5c). Ev goed om ontsnapping te tellen, opnieuw enkel kleinere tegen bovenkant. Loodtouwtjes weinig effect. (5b)

Camera in buik onder paneel omhoog:

Start $2^{\mathrm{e}}$ filmpje: veel passerende vis, zicht op paneel zonder bovenkuil langs onder. Enkel kleinere vis die reeds dicht bij paneel zit doet poging om er door te ontsnappen, rest gaat er onderdoor (5c)

\section{Trek 6: zonder overkuil met lampen}

Camera in buik onder paneel omhoog:

- !! net gaat maar heel even mooi openstaan en valt nadien weer toe, continu heel veel vis die over net gaat, mogelijks weer niet mooi open? (6a)

- $\quad$ GP20224: op einde: gaat ff mooi open, zeer veel vis boven net. Vis reageert zenuwachtiger met lampen (of door laag net?) en maakt meer 'burst' bewegingen en ontsnapt

GP30224: goed stuk om otnsnapping te tellen

- Vooral wijting in stuk zonder licht? Meer ontsnappingspogingen? (6b en 6c) $=>\%$ ontsnappingTELLEN?

Camera in rug naar voor:

- Touwtjes van lampen aan touw + touwtjes onder paneel verstrikt, mogelijks hierdoor dat staart en paneel niet mooi openstaat op voorgaande beelden?

- VEEL donkerder beeld (omdat camera naar lampjes kijkt?) waar weinig op te zien valt, op einde iets klaarder (6d) en duidelijker beeld op moment dat er uitgepikt wordt waarbij alles naar voor schiet $\left(6^{\mathrm{e}}\right)$ om weer naar achter geblazen te worden op het moment dat kuil wordt binnengehaald $(6 f)$

Camera OP rug naar achter:

Eerst te donker en geen vis, nadien vis maar camera kijkt omhoog en niet over paneel Vanaf minuut 14 van GP20013 zie je over paneel

Vlotte ontsnapping wijting in begin $(6 \mathrm{~g})$, ook zijdelingse ontsnapping wijting bij geplooid paneel $(6 \mathrm{~h})$ en later in haalproces $(6 \mathrm{i})$

\section{Trek 7: zonder overkuil met lampen}

\section{Camera OP rug naar achter:}

Min 7: eerste vis = plativs. Rug veel meer open dan buik (7a)

- Min 10: eerst enkelingen voor lampen (ervoor door het licht of gewoon ervoor omdat vissnelheid nog gezapig is?), kort erna grote bal vis. Het feit dat er een 'bal' ontstaat doet vermoeden dat vis ergens 'opstropt' (7b)

- Min 13: wijting ontsnapt maar blijft voor camera in plooi van net kuieren (dus voelt zich op zijn gemak bij beschutting van netmateriaal uit stroom en niet geneigd 'het ruime sop' te kiezen ). Of is deze niet ok aangezien rest wel direct wegzwemt? Waarom staat het net zo geplooid?

- $\quad$ Min 17: vis al meer opgejaagd door hogere watersnelheid die ze nauwelijks kunnen bijhouden (7c)

- $\quad$ Min 0 en min 1 van volgende filmpje: schichtiger door hogere snelheid. Reactie op licht moeilijk te zien $(7 d)$

Camera in rug naar voor: 
- Min 10: eerste vis die binnenkom maar nog geen vorm in het net, goed beeld op touwtjes, vis goed te tellen maar weinig individuen $\left(7^{\mathrm{e}}\right)$

Min 14: idem, staart iets mooier open. Er lijken wel veel wijtingen net voor camera uit beeld te verdwijnen, onduidelijk of die door rug gaan (reactie op go pro ?) of er over waaien (7f). Weinig reactie op touwtjes

Min 1: tot 6: binnenkomende haring = zottekot.

Min 8: haring die ontsnapt doet het horizontaal door plooien in paneel! Niet verticaal! (7g $\mathrm{hh}$ )

Min 10: boordevol haring +-7 min voor einde trek (7h)

Min 14: haring geconcentreerd aan 1 kant: schoolzwemer! (7i)

Min 17: net wordt uitgepikt

Camera in buik onder paneel omhoog:

Min 8 en verder: net staat echt niet mooi.

Min 9: mooie ontsnapping wijting bij licht, zwemgedrag oogt onregelmatiger met meer bursts, door lichtjes? (7j)

Min 9 en verder $+\min 17$ en verder: ontsnapping redelijk te tellen

Min 1: inktvis en kabeljauw in beeld + sleepsnelheid nu te hoog om nog vlot snelle (zijdelingse) bewegingen (bursts) te maken voor wijting. Kabeljauw geeft weinig reactie. (7k) Min 6+ min 9: blije intrede der haring. 'zoekt' veel minder ontsnapping dan wijting, duidelijk meer een schoolzwemmer die het midden van staart zoekt.

Min 9: Haring Lijkt naast de lichtjes te blijven en zwemt er niet echt tussen. (7I)

Min 13 haring zoekt hoogste punt (in dit geval weg van lichtjes) en zwemt naast plooi. Waarom net nu weer geplooid ondanks grotere doorstroom? (touwtje of lichtje dat vastgehaakt zit??) (7m)

Min 15.45: stilvallen van snelheid door uitpikken, klein deel van vis komt naar voor en ontsnapt $(7 \mathrm{~m})$

$\Rightarrow$ Moeilijk te zeggen of ze het licht omzeilen. We zien op beelden maar de helft van het paneel (met licht) waardoor er jammer genoeg geen vergelijking te maken valt

\section{Zonder mechanische of visuele stimuli: net met $150 \mathbf{~ m m}$ ontsnappingspaneel in rug}

Trek 8: laatste trek 4/4, te donker niet gefilmd

Trek 9: eerste trek 5/4, te donker niet gefilmd

Trek 10: donker bewolkt en veel te ruwe zee, niet gefilmd

Trek 11: Gefilmd in netopening, veel schade en weinig goede beelden.

Achter bodempees naar voor: geen beelden, camera en frame losgerukt en verloren.

Achter bovenpees naar voor: weinig bruikbaar, afstand te groot.

13.40 tot 13.50 : voorbeeld zicht op het grote niets (11a)

16 tot 16.10: zicht op bollen bovenpees helemaal op einde van trek (11b)

In spie naar achter: weinig bruikbaar, frame platgeplooid (op nettenrol?) waardoor filmhoek slecht was. Vaak met neus in het zand of opgedraaid (?!). Grondpees niet ok, vaak omwikkeld met net. Start filmpje: beweging tov grond $+-4-5 \mathrm{~m}$ per minuut.

Eerste minuten: zicht op zandbodem met veel kleine springende garnalen (?) (11c)

Dan camera 3 min lang met neus in zand, hij komt er uit, kijkt tijdje naar bodempees, komt dan recht en kijkt zijdelings naar bodem voor klossenpees (vluchtende tarbot), weer meer naar bodempees die opgedraaid ligt in net en wordt uiteindelijk zelf omwikkeld. (11d)

Nog 2 min later: net omwikkeld nogmaals, op einde bovenaan ontsnappende vis?? $\left(11^{\mathrm{e}}\right)$

Nog 2.5 min later: net ff in beeld, komt recht en gaat weer neer (11f)

Nog 1 min later: net lijkt nog eens rond te wikkelen $(11 \mathrm{~g})$

Rest van beelden: zwart of waas

Trek 12: niet gefilmd, frames repareren na schade trek 11

Trek 13: kabel geknapt in het begin van het haalproces. Geen beelden met vis.

Trek 14: gefilmd op rug om te kijken waar vis ontsnapt, weinig te zien

$\Rightarrow$ hele trek bewaard voor tijden te schatten indien/waar nodig

Rug $4 \mathrm{~m}$ voor paneel 
- $\quad 3^{\text {e }}$ fragment: zeer veel activiteit net onder rug en tegen rug, maar niks ontsnapt. Ook niet door gaatje in rug (14a)

- $\quad 4^{\mathrm{e}}$ fragment: $\min 12$, jan van genten show (14b)

Rug 12-15 m voor paneel:

zelfde beelden als $4 \mathrm{~m}$ paneel.

- $\quad$ Geen extra info/meerwaarde. Ook hier nergens ontsnapping te bespeuren

OP rug thv begin van paneel, naar achter en beneden kijkend

Net mooi open deze keer!

$15^{\prime}$ start platvis

- $\quad 17.20$ tot eind $1^{\text {e }}$ fragment: veel platvis, allemaal op buik, kop naar achter. Geen weerwerk of vlucht omdat ze al uitgeput zijn? (14c)

$\mathrm{Na} 15 \mathrm{~min}$, of $13 \mathrm{~min}$ in $2^{\mathrm{e}}$ fragment: eerste makreel (14d)

17.30 tot einde : (20' na eerste platvis vollenbak rondvis) (14e en f)

- $\quad 3^{\mathrm{e}}$ fragment: $12.10 \mathrm{~min}$ vis die naar voor komt door stoppen met halen, kleine vis die ontsnapt (niet geknipt wegens zelfde als vroeger)

\section{Trek 15: gefilmd op rug, weinig te zien}

Camera op rug $10-15 m$ voor paneel:

- $\quad$ Eerste filmpjes gewoon net water en bloei. Rest ook op laatste filmpje. Eerste verwijderd

- Begin filmpje: je ziet vis zwemmen in staart, maar nergens ontsnapping door mazen, ook niet van kleinste wijting of haring. Alle ontsnapping lijkt dus door paneel te moeten gebeuren (15a)

- $\quad$ Op geen enkel van de (verwijderde) fragmenten zie je vis boven net langs komen. In deze trek dus geen verlies zoals geobserveerd tijdens sommige andere.

- Op einde van trek zie je geen vis in beeld komen. Als er dus een (deel van de ) vis is die terugkeert zoals geobserveerd op andere filmpjes, dan is dit beperkt in afstand

Andere camera op rug: mislukt, geen beeld, fout op kaart

Camera achter paneel naar voor kijkend: enkel zicht op water, geen zicht op paneel.

Je ziet hier en daar wel vis passeren, maar geen meerwaarde tov vorige (geselecteerde) beelden.

\section{Algemene patronen}

Net recht en vullend vanaf 25-30 min na te water lating

Platvis komt binnen vanaf laatste 30-40 min van trek

Wijting komt het net binnen vanaf laatste 15-30 minuten van trek

Haring komt pas net binnen in laatste 10-15min van trek

- Haring gegroepeerd, soms enkel bovenaan, soms zijkant. Geobserveerde ontsnapping bijna altijd zijdelings.

- Wijting die ergens tegen tikt (bv waar paneel samengezet is) maakt makkelijker beweging omhoog. Paneel met meer ribben zou dus efficiënter kunnen werken. 'dansend' paneel zal ook tot meer ontsnapping leiden.

- Hoe strakker net openstaat, hoe minder ontsnapping. Hoe meer ribbels en plooien, hoe makkelijker ontsnapping

- In aanwezigheid van licht lijken ze schichtiger te bewegen

\section{Conclusies camerawerk april 2018}

- Rudimentaire vangstanalyse van trek 3 toont aan dat verlies van commerciële vis door paneel in rug verwaarloosbaar is: 5 maatse wijtingen en een inktvisje op een zak van 200-300 kg geloosde vis.

- Vaak komt eerste rondvis als een 'bal': ze stroppen ergens op en net opent pas later

- Idee met touwen en vlotters is geen optie aangezien het net te laat open gaat en de tijd om tot scheiding te komen, zeker bij een bal vis, te kort is om een goed resultaat te bekomen.

- $\quad$ Sommige trekken vis over net, andere onderpees en spie opgerold: netopening vist niet altijd stabiel en betrouwbaar.

Een 'dansend' bovenpaneel of een dat in plooien ligt (en zijdelingse ontsnapping mogelijk maakt) lijkt ontsnapping te verhogen.

- Aanwezigheid van lampen lijkt tot schichtiger gedrag te leiden, wat kans op ontsnapping zou moeten vergroten. Om dit te bevestigen is een vangstanalyse nodig. 


\section{Archivering beeldmateriaal}

Ruwe beelden staan gebackuped bij het ILVO

De meest relevante fragmenten (aangegeven hierboven) werden uit de ruwe beelden geknipt, genummerd per trek en afzonderlijk opgeslaan.

Deze fragmenten werden doorgestuurd naar Arie Lokker (Cooperatie Stellendam), Eric van Linden (Jaczon) en de vissersbond. 


\section{ii. Waarnemingen SCH135 januari 2019}

Algemene condities: zeer ruw weer in dagen voor de reis + lage zonintensiteit zorgen voor beperkte helderheid van het water waardoor er niet gefilmd kon worden op de bodem (te donker). De indrukken beschreven hieronder zijn dus beperkt tot wat te zien kort na het wegzetten en kort voor het binnenhalen van het net.

Aangezien de focus van deze reis lag op de vangstanalyse en de omstandigheden om te filmen niet goed waren werden er slechts tijdens 3 trekken opnames gemaakt.

Er werd steeds gevist met een ontsnappingspaneel zonder extra stimuli.

\section{Trek 5:}

Op rug naar achter kijkend naar overkuil:

- $\quad$ Staart nog niet open, maar overkuil valt niet langszij en schaduw van overkuil mooi gecentreerd in midden van buik.

- $\quad$ Onvoldoende doorstroom op overkuil te doen openzetten

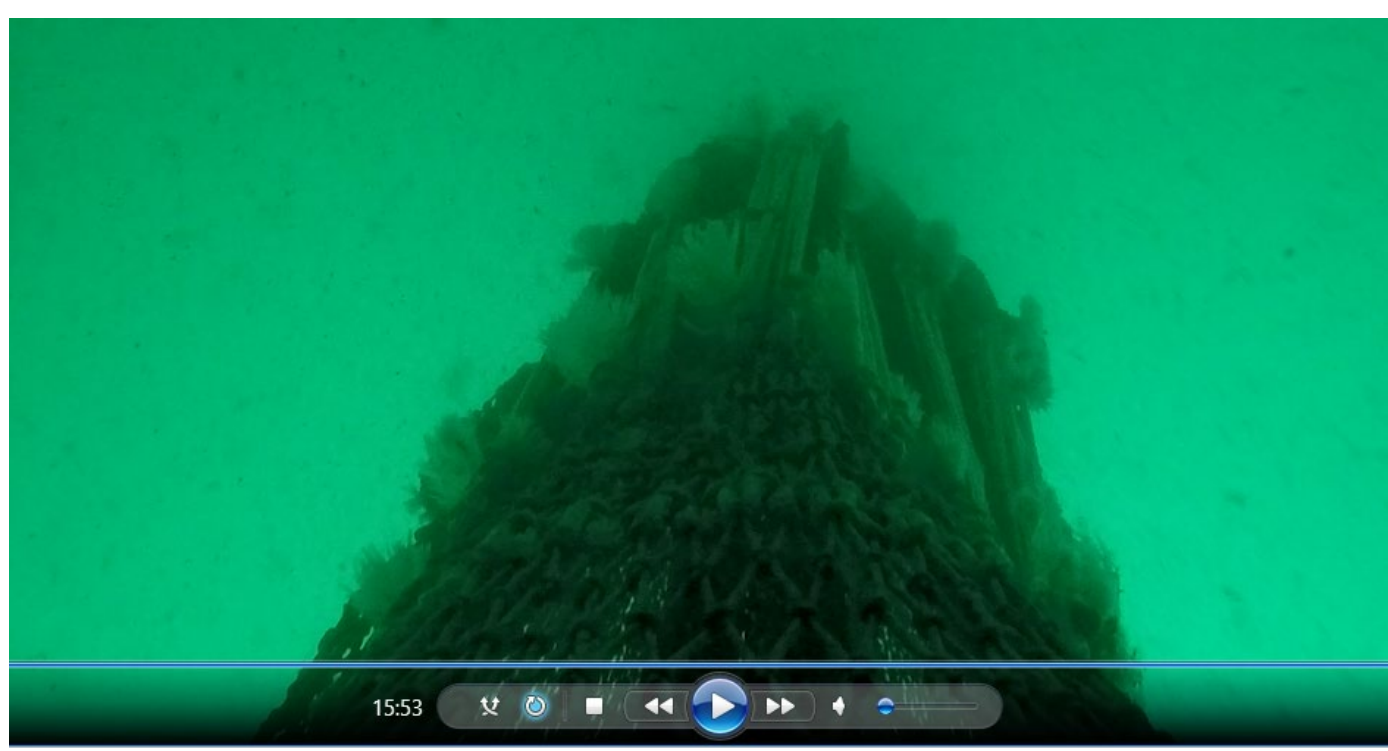

Op buik omhoog kijkend naar paneel:

- Vlottertjes doen hun werk: Zelfs zonder doorstroming zweeft overkuil boven paneel

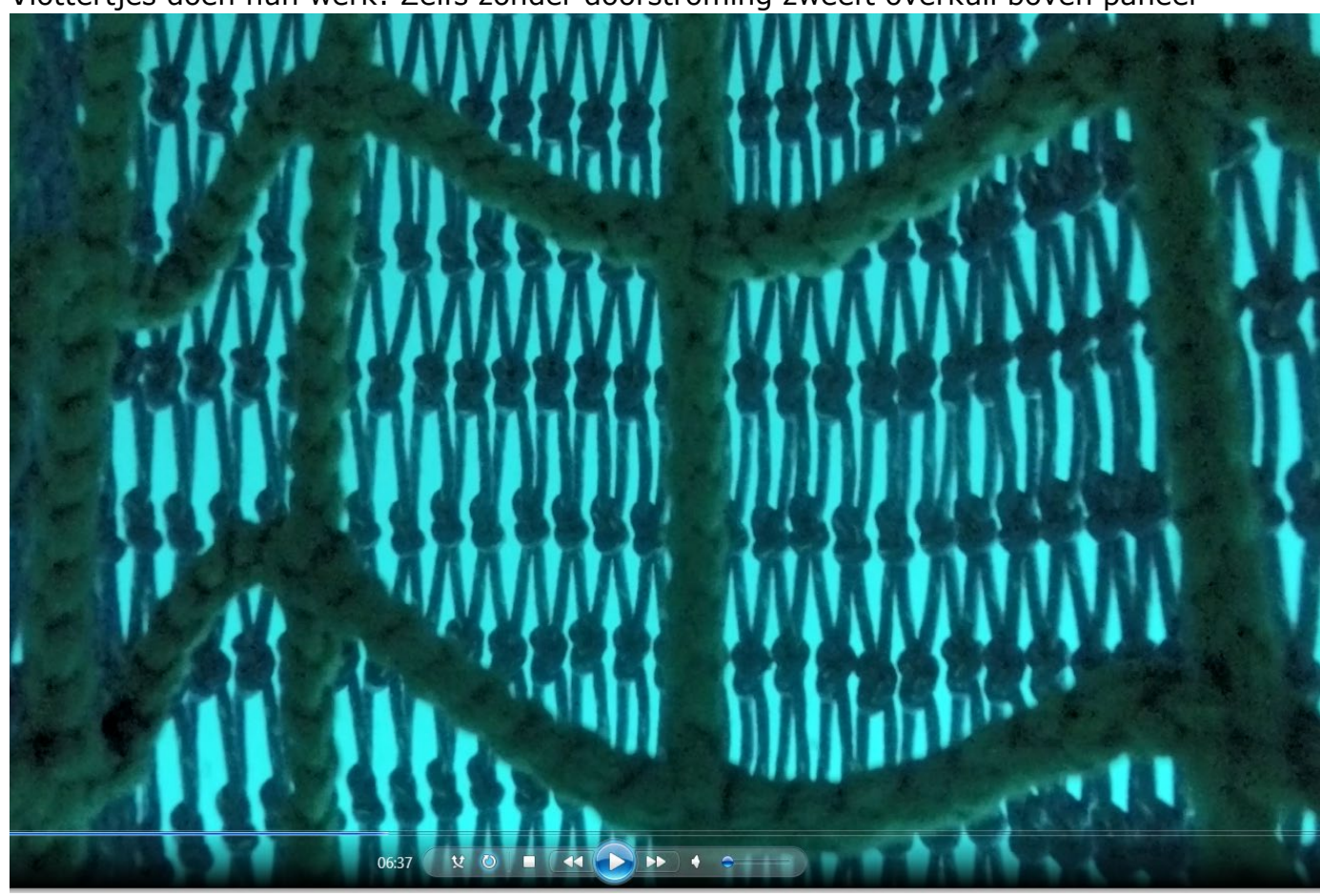


Paneel ligt zelfs bij goede doorstroming net voor binnenhalen van net nog gegolfd, dus dit is vermoedelijk altijd zo.

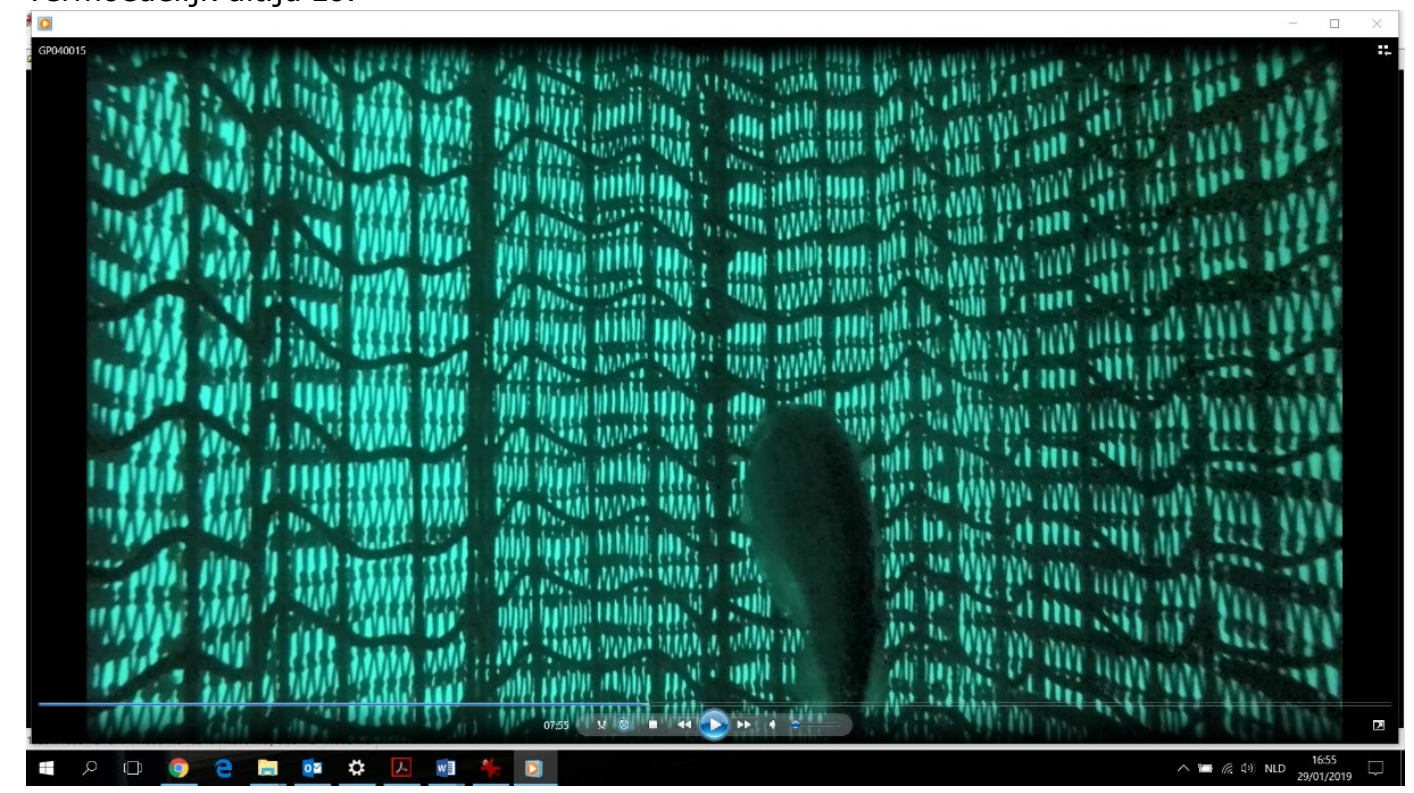

Vangst en ontsnapping niet zichtbaar wegens te donker. Zwemgedrag + terugschuiven van wijting bij uitpikken net wel zichtbaar: deel zwemt rustig terug, geen intenties om te duiken.

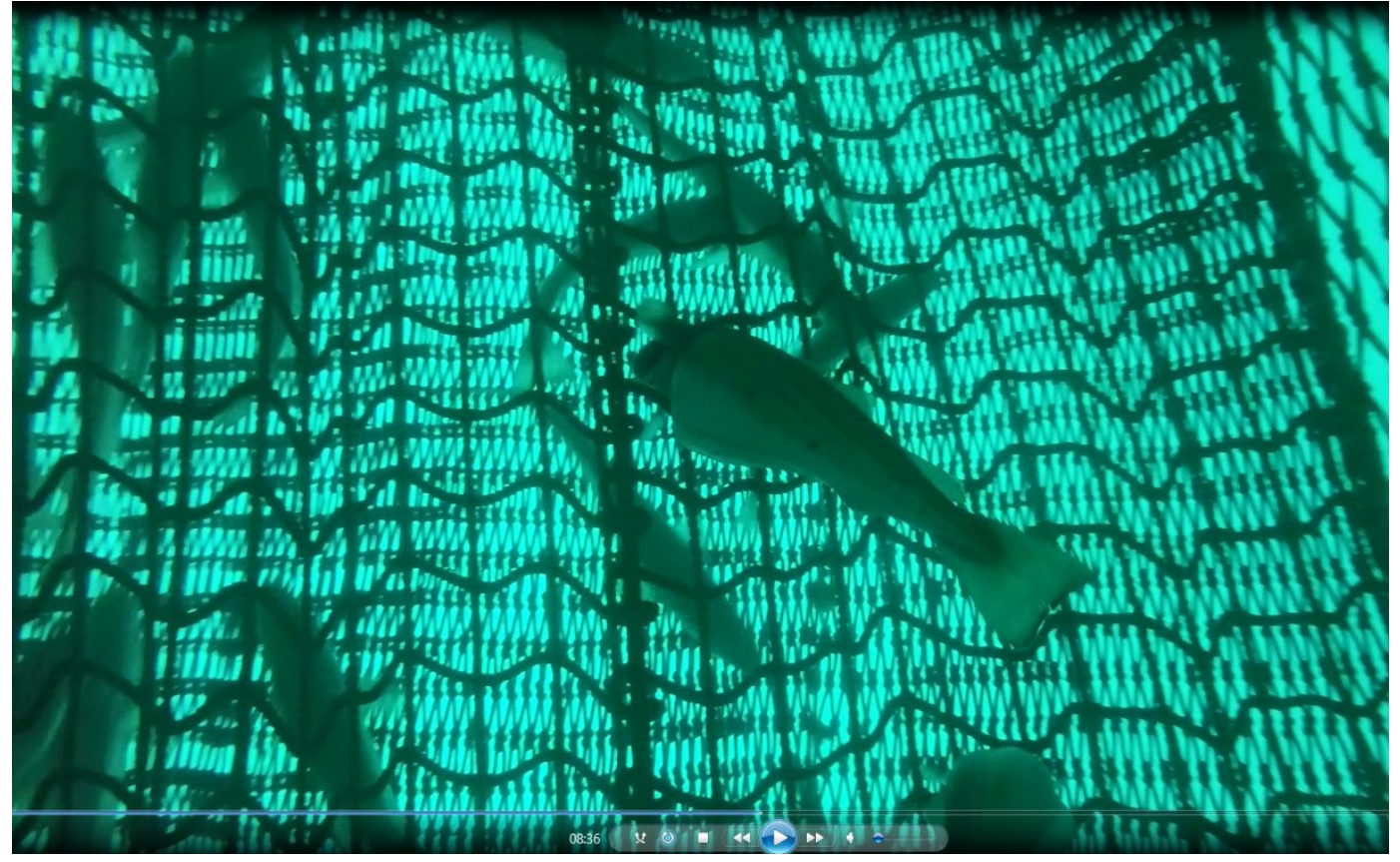


Op rug naar achter kijkend naar overkuil:

- Einde trek met goede doorstroom: overkuil staat mooi recht naar achter, en lijkt mooi horizontaal te hangen

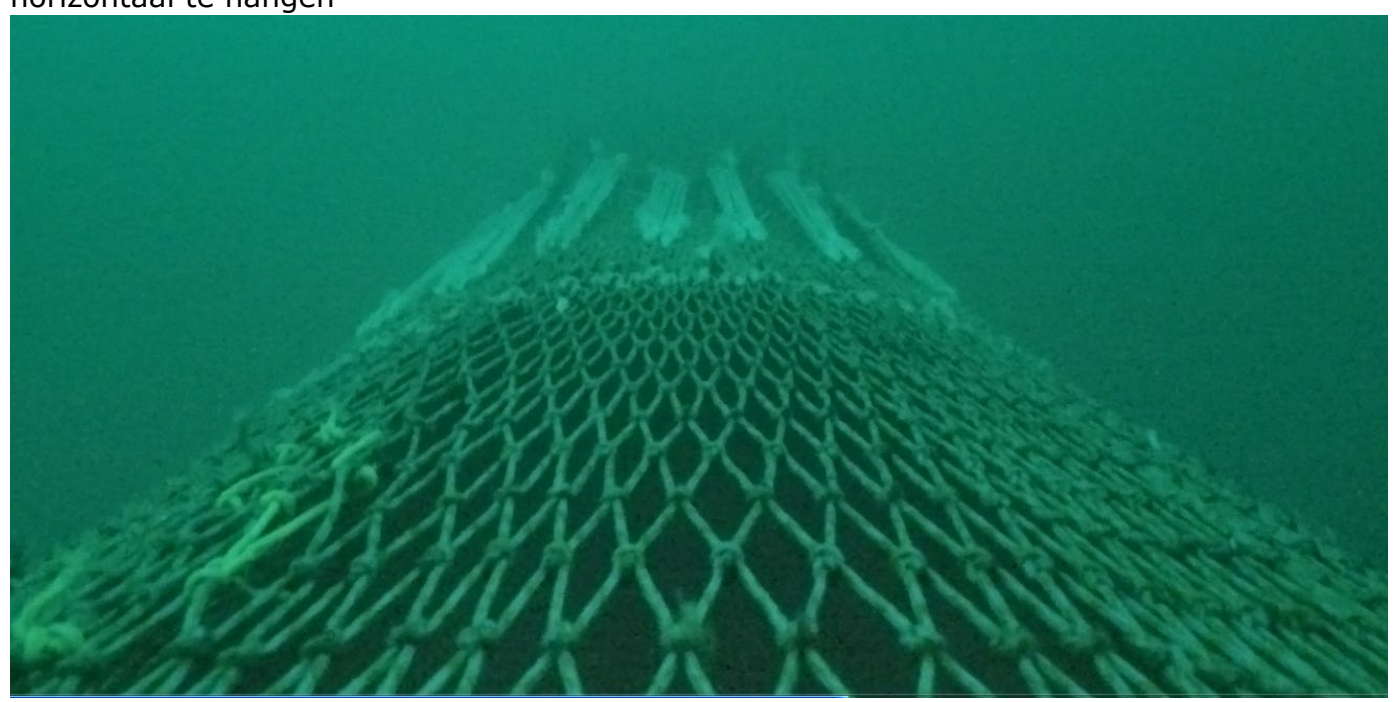

- $\quad$ Overkuil blijft mooi parallel met kuil hangen + Jan van Gent armada

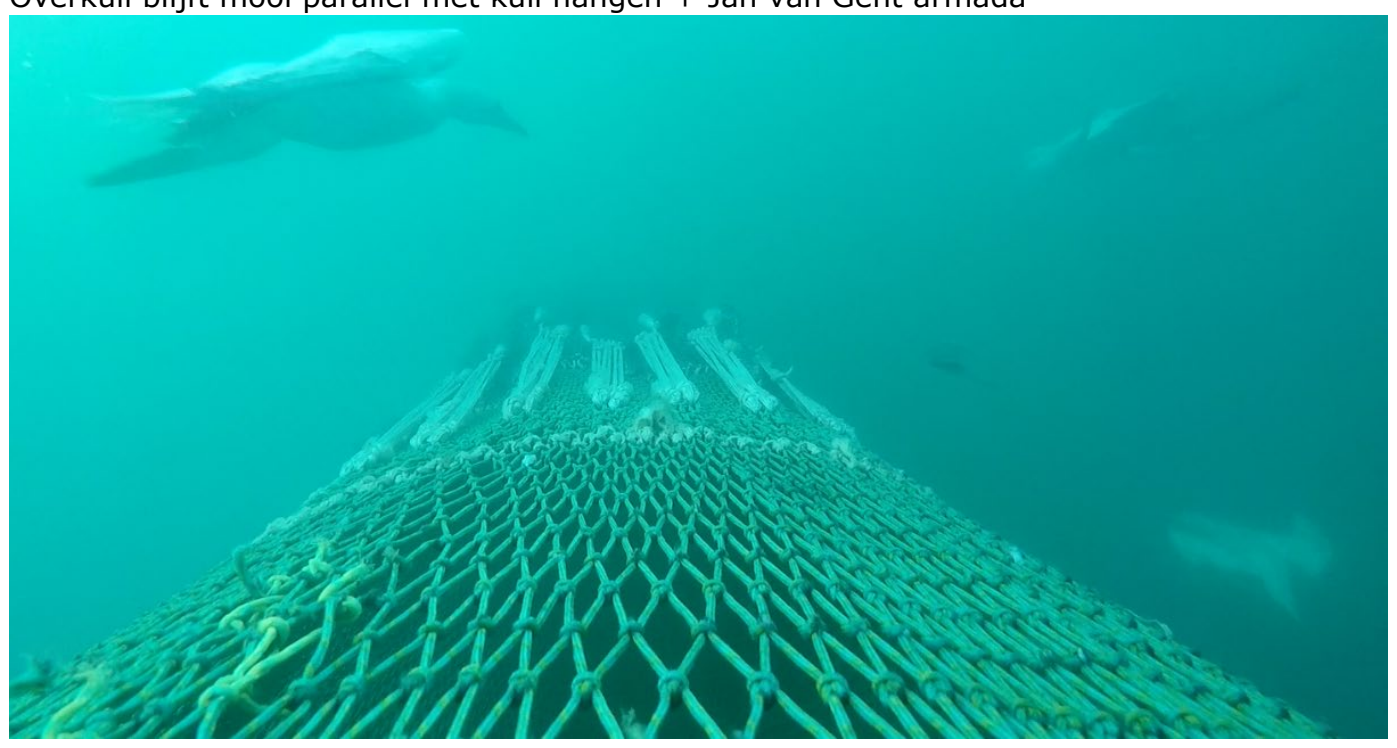

Op buik omhoog kijkend naar paneel:

- Vis zichtbaar rond tijdstip van uitpikken bij terugschuiven: steenbolk lager tegen buik, mul (rechts) secondenlang rusting in plooi van het paneel zonder poging om opwaards of zijdelings erdoor te zwemmen

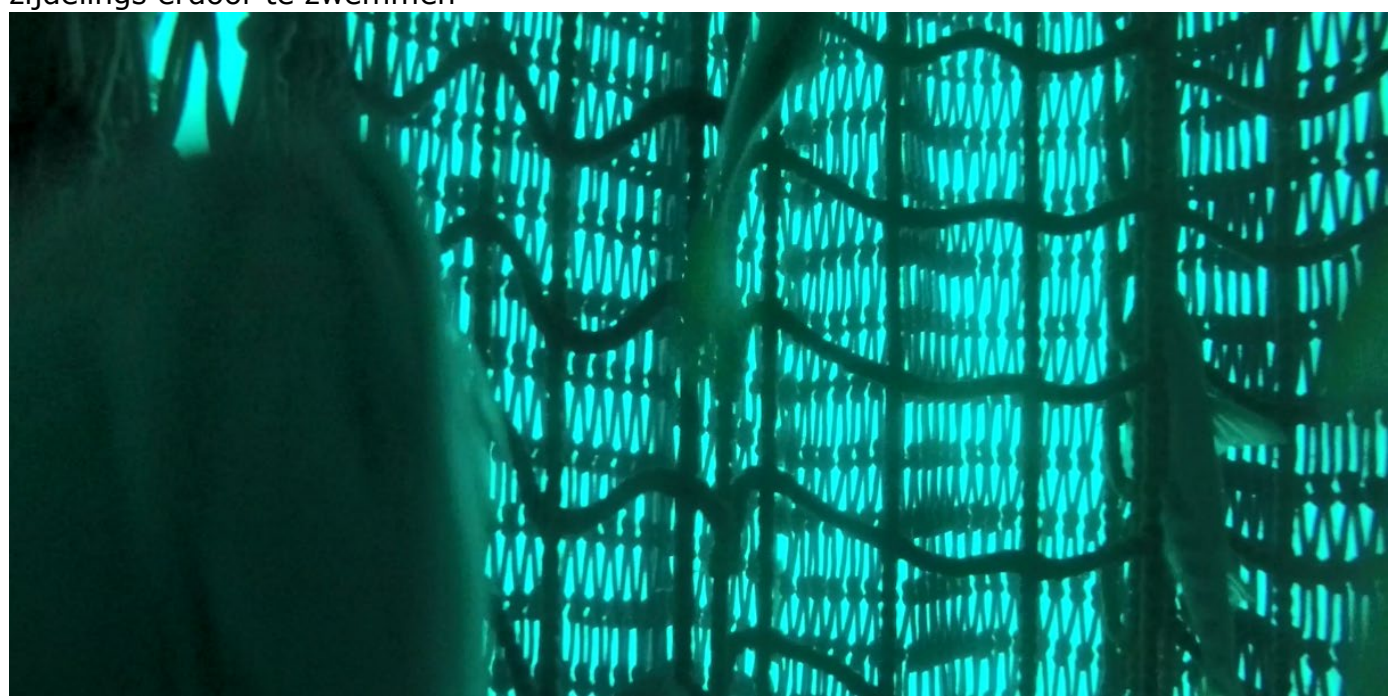




\section{Trek 13:}

Op rug naar achter kijkend naar overkuil: idem trek 12.

Op buik omhoog kijkend naar paneel: deel doorstroom naar kuil zichtbaar

Meerderheid gaat onder paneel door, enkeling gaat er toch door

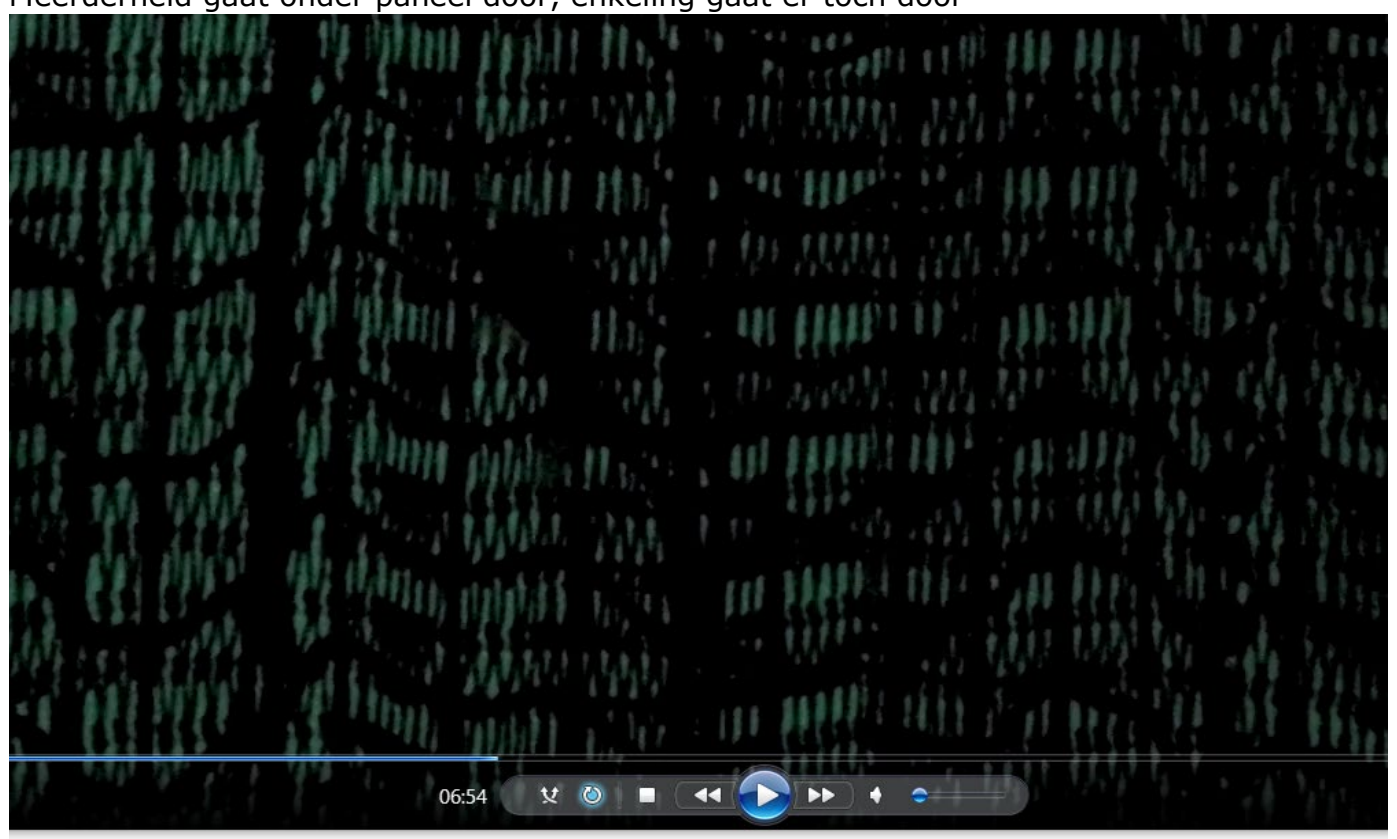

Zolang tempo het toelaat blijft wijting in overkuil op zelfde hoogte tov het paneel meezwemmen + overkuil blijft mooi weg van paneel

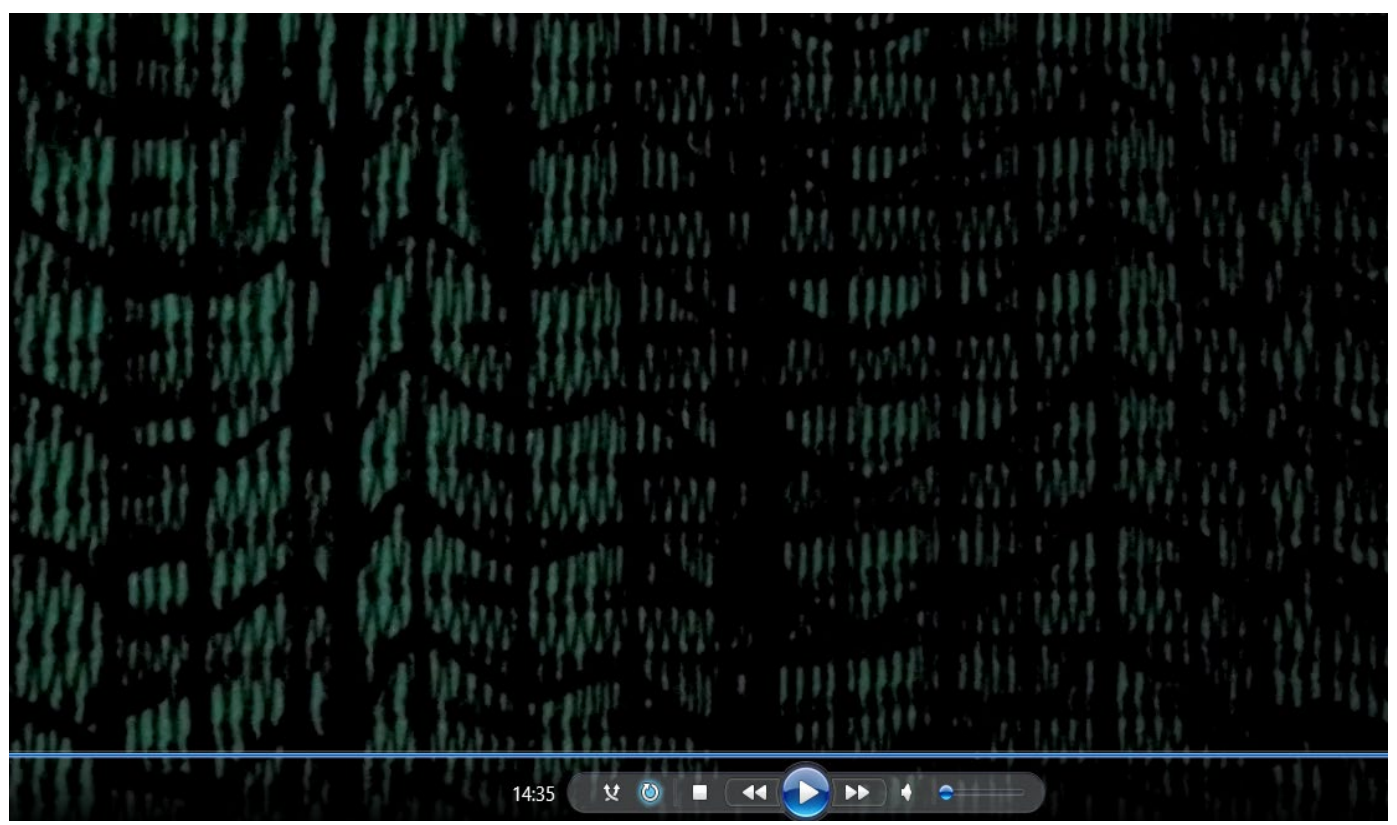

\section{Conclusies}

Zeer beperkt zicht op werking op bodem wegens te donker. Beelden van trek 13 suggereren dat alles zich gedraagt zoals bedoeld.

voldoende ruimte tussen overkuil en paneel: geen belemmering van ontsnapping paneel meestal gegolfd wat ontsnapping mogelijks bevordert. 


\title{
Bijlage 11: Flyshoot reisverslagen
}

\section{iii. Reis 1 (maart 2017): net zonder aanpassingen}

\author{
Vaartuig: SCH-135 'Galibier'
}

Reisduur: 15 en 16 maart 2017

Aantal trekken: 6 trekken uitgevoerd, 4 trekken kunnen filmen, 3 trekken met bruikbaar materiaal Opstappers: Bart Verschueren (ILVO) en Maarten Soetaert (ILVO)

De SCH135 'Galibier' pikte ons en Eric van Linden op rond middernacht in Boulogne-sur-mer. De eerste vroege ochtend trek werd er geen poging tot filmen gedaan omdat het sowieso nog te donker was. Vanaf de $2^{\mathrm{e}}$ trek werd er gefilmd, maar pas tijdens de $3^{\mathrm{e}}$ trek was de lichtintensiteit/kwaliteit voldoende om iets te kunnen onderscheiden op de beelden. Dit kwam deels door de dichte mist die er 's ochtends hing maar de naar de middag toe opklaarde tot een zonnige en windstille dag. De omstandigheden onder water waren minder ideaal daar het water niet helemaal helder was.

Tijdens deze derde trek kon enkel iets gezien worden op de camera die net voor de kuil in de rug van het net was gehangen. Deze toont grote hoeveelheden makreel die dicht op elkaar naar de kuil gestuwd worden. Interessant echter is om te zien hoe heel deze 'bal' vis plots vooruitschuift op het einde van het vangstproces wanneer de kettingen overgepikt dienen te worden en de snelheid uit het net ging. Mogelijks gaat er tijdens deze fase een deel van de vis verloren via de voorkant van het net of een ontsnappingspaneel indien aanwezig.

Hetzelfde fenomeen is opnieuw zeer duidelijk te zien in de volgende trek (GPO30189.mp4 8min20s) vanuit hetzelfde camerastandpunt. Daarnaast is te zien hoe eerst de platvis langzaam naar binnen komt, de hoeveelheid platvis langzaam toeneemt en er ook meer en meer rondvis binnenkomt (GPO20189). Beelden uit de onderkant van de netopening geven jammer genoeg weinig info en vertonen vooral zand. De camera lijkt hier ook wat gedraaid geweest te zijn.

Tijdens de laatste bruikbare trek werd er gefilmd vanuit de staart richting de netopening en opnieuw van uit de netopening richting de grondpees. Het eerste fragment uit de kuil toont enkel netmateriaal, dat initieel na uitzetten plat op de grond licht en langzaam mooi open komt te staan naarmate het haalproces vordert. Eens het net open staat is enkel de rug en het bovenste deel van de waterkolom in het net zichtbaar door de troebelheid van het water. Op deze beelden zien we langzaam een school vis binnenkomen, de gehele breedte van het net vullen en naar achter afdrijven (GPO20729). Naarmate de snelheid opgevoerd wordt versmalt het net. Belangrijk is dat we op het einde van de trek geen vis naar voor zien schuiven, wat aangeeft dat de naar voor schietende bal vis uit opnames van de voorgaande 2 trekken niet voorbij de helft van de staart geraken en niet de oversteek maken naar de voorkant uit het net. De beelden van de grondpees zijn bijzonder wazig door de troebelheid van het water. Je ziet op het einde van het proces grote hoeveelheden vis over de grondpees het net binnenkomen, maar het is niet mogelijk op te maken om welke soorten het gaat of welke soort wanneer binnenkomt. Ook hier zie je echter op het einde van de trek geen vis voorbij komen, wat bevestigd dat er geen vis langs de mond van het net ontsnapt tijdens de plotse val in snelheid en het naar voorschuiven van de vis. Ondanks de slechte zichtbaarheid geven deze beelden ons wel nog een geheim prijs. Bij het binnennemen van de kuil bleek er een groot gat in het net te zitten waarvan de oorzaak moeilijk in te schatten was. Op de beelden zien we echter bij het begin van de trek (fragment 'steen' vanaf 27s) een grote menhir in het pad van het net komen, die eerst de bodempees een tijd lang op een punt trekt maar uiteindelijk toch in (en later dus door) het net beland.

Door het tijdsverlies gepaard gaande met de herstellingen was er onvoldoende tijd om nog een trek te filmen. Het materiaal werd opgeruimd en beelden gebackuped voor de weg naar huis. Door de gelimiteerde zichtbaarheid en het beperkt aantal trekken waarin gefilmd kon worden leverde deze reis jammer genoeg weinig nieuwe informatie en inzichten op met betrekking tot het gedrag van de vissen, in het bijzonder wijting. Hopelijk ondervinden we bij een volgende poging minder overmacht.

\section{Resultaten beeldanalyse:}

vangst schuift terug van kuil naar staart wanneer er gestopt wordt met halen om uit te pikken.

- Eerst platvis in net (onderaan), daarna de rondvis (hoger in staart). Telkens golven qua aantal. 
- In sommige trekken opent staart pas laat en komt de vis niet geleidelijk aan door de staart maar als 1 grote bal van verschillende soorten.

\section{iv. Reis 2 (april 2018): net met ontsnappingspaneel (rug) en extra stimuli}

Vaartuig: SCH-135 'Galibier'

Reisduur: 4 en 5 april 2018

Aantal trekken: 15 trekken uitgevoerd, 10 trekken kunnen filmen, 9 trekken met bruikbaar materiaal Opstappers: Maarten Soetaert (ILVO) en Christian Vandenberghe (ILVO)

Eerste indrukken:

- Zeer goede zichtbaarheid

- Magere vangsten

- $\quad$ Eerste dag veel wijting (en haring en wat makreel), $2^{\mathrm{e}}$ dag wat minder wijting en meer platvis.

- Mooie beelden van het paneel in de rug van het net.

- $\quad$ Vis reageert (quasi?) niet op gekleurde touwtjes. Ook op de (flikker) lichten kwam er weinig reactie. Hier kunnen we dus weinig extra mee aanvangen

- $\quad$ Het idee met de touwen en vlotters werd iteindelijk niet getest, omdat het net deze reis veel later openkwam en, in tegenstelling tot vorige reizen/beelden waar de vis geleidelijk aan binnenkwam, alle vis grotendeels als 1 grote bal aan het paneel voorbij kwam waardoor het zinloos was van te proberen sorteren op basis van tijdstip dat ze in staart/kuil kwamen. Het was onduidelijk waarom dit zo gebeurde (meer dan vorige keer), maar het maakt selectiviteit enkel moeilijker.

- Het paneel zelf werkte heel goed. Heel veel beelden van (voornamelijk wijting) die er door ontsnapte.

- $\quad$ Overkuil werd na $3^{e}$ trek weggesneden omdat hij het net samentrok en het paneel helemaal niet mooi open stond en het dus veel te ver van de praktijk stond. De ontsnapping door het paneel was tijdens de trekken met cover ook veel groter omdat de helft van de tunnel maar $30 \mathrm{~cm}$ hoog was, waardoor de vis veel meer contact maakte met het paneel en er door ontsnapte. De vangsten in de overkuil tijdens die trekken waren ongeveer een derde van het totaal waarvan nagenoeg niets maats was.

- $\quad$ Er werd een trek afzonderlijk verwerkt en op de hele overkuil (alles wat door het paneel gegaan was) wat makkelijk $300 \mathrm{~kg}$ vis was zaten er een 5 tal maatse wijtingen en een klein inktvisje. Dit toont dus wel aan dat het paneel zeer goed werkt om ondermaatse rondvis (en zeker wijting) te lozen zonder dat er een commercieel verlies is.

Enige vraagteken is hoeveel mul er door gaat (aangezien deze niet gevangen werd). 


\section{v. Reis 3 (januari 2019): vangstanalyse}

Vaartuig: SCH-135 'Galibier'

Reisduur: 14 en 15 januari 2019

Aantal trekken: 15 trekken uitgevoerd, 3 trekken gefilmd, 13 trekken overkuil bemonsterd, 10 trekken volledige vangst bemonsterd.

Opstappers: Maarten Soetaert (ILVO) en Mattias van Opstal (ILVO)

De omstandigheden waren, zeker voor te filmen, niet ideaal door het stevige weer, maar gezien de einddatum van het project waren er geen alternatieven meer beschikbaar. Het voornaamste doel van deze reis was echter het analyseren van de vangsten en het in kaart brengen van de hoeveelheid ontsnapping van wijting door het paneel, waarbij de camera beelden enkel nodig waren om te kijken of het paneel en de overkuil goed stonden. Aangezien er consequent mooie hoeveelheden inktvis, wijting en mul gevangen werden, aangevuld met veel poon, steenbolk en verschillende soorten platvis waren de vangst(samenstelling)en zeker een succes te noemen. De samenwerking met de bemanning verliep vlot en er was net voldoende ruimte in het schip om de sorteertafel en weegschalen op te stellen.

De vangsten van de overkuil die op het paneel zat werd telkens voor $100 \%$ uitgesorteerd en geanalyseerd terwijl er van de gewone kuil een submonster werd genomen van 50 tot $80 \mathrm{~kg}$. Er werd geopteerd voor een volume meting van de stortbak om het totale gevangen volume in te schatten en de substalen van de kuil nadien op te kunnen schalen. Gezien de grootte van de hopper lijkt het echter aangewezen om volgende keer de kuil te wegen en rechtstreeks vanuit de gewichten te vertrekken, aangezien dit een accurater resultaat zal geven en makkelijker te bepalen is.

Een tweede waarnemer hielp bij het sorteren en meten van de stalen, maar stond tijdens het sorteerproces van de bemanning op het einde aan de band. Het doel hier was om te tellen hoeveel individuen wijting er gediscard werden en dit door middel van een monster om te rekenen naar een volume en gewicht, wat een $100 \%$ exacte inschatting van de wijting discards had gegeven. Gaandeweg is echter gebleken dat er bij grote wijtingvangsten niet alle maatse wijting kon worden uitgegooid. Hierdoor is uiteindelijk besloten van deze cijfers niet in te sluiten in het rapport.

Tijdens 1 trek op maandag en 2 trekken op dinsdag werden er 2 gopro's in het net gemonteerd. Een ervan stond op de rug en keek naar achter om een beeld te krijgen van hoe de overkuil stond. Een tweede lag op de buik en keek omhoog naar het paneel om te controleren of er voldoende ruimte was tussen de overkuil en het paneel en ontsnapping niet belemmerd werd wat de resultaten van de vangstanalyse zou vertekenen. De zichtbaarheid en lichtintensiteit was echter matig, waardoor er enkel beelden zijn van het begin en einde van het vangstproces als het net niet te diep was. De gemaakte opnames bevestigen echter dat de overkuil zicht mooi horizontaal en in lijn met de gewone kuil bevond en ook voldoende ruimte liet boven het paneel om ontsnapping niet te belemmeren.

Wegens tijdgebrek werden tijdens de 3 trekken dat er met gopro's gewerkt werd enkel de overkuil geanalyseerd.

De gemiddelde maaswijdte van het ontsnappingspaneel was $87.8 \pm 2.3 \mathrm{~mm}$ en die van de overkuil was $55.2 \pm 1.0 \mathrm{~mm}$. 


\section{(c) Wageningen Marine Research}

Wageningen Marine Research, instituut binnen de rechtspersoon Stichting Wageningen Research, hierbij vertegenwoordigt door Dr. M.C.Th. Scholten, Algemeen directeur

KvK nr. 09098104,

WMR BTW nr. NL 8113.83.696.B16.

Code BIC/SWIFT address: RABONL2U

IBAN code: NL 73 RABO 0373599285
Wageningen Marine Research aanvaardt geen aansprakelijkheid voor gevolgschade, noch voor schade welke voortvloeit uit toepassingen van de resultaten van werkzaamheden of andere gegevens verkregen van Wageningen Marine Research opdrachtgever vrijwaart Wageningen Marine Research van aanspraken van derden in verband met deze toepassing.

Alle rechten voorbehouden. Niets uit deze uitgave mag weergegeven en/of gepubliceerd worden, gefotokopieerd of op enige andere manier gebruikt worden zonder schriftelijke toestemming van de uitgever of auteur.

A_4_3_1 V28 (2018) 